SOLANGE LABBONIA

\title{
Tópico, Foco e Contraste no Português Brasileiro e no Espanhol Peninsular: uma visão discursivo-funcional da ordenação dos constituintes
}

Tese de Doutorado apresentada ao Programa de Pós-Graduação em Língua Espanhola e Literaturas Espanhola e Hispano-Americana da Faculdade de Filosofia, Letras e Ciências Humanas da Universidade de São Paulo.

Orientadora:

Profa. Dra. Neide T. Maia González.

Versão corrigida

São Paulo 
Autorizo a reprodução e divulgação total ou parcial deste trabalho, por qualquer meio convencional ou eletrônico, para fins de estudo e pesquisa, desde que citada a fonte.

Catalogação na Publicação

Serviço de Biblioteca e Documentação

Faculdade de Filosofia, Letras e Ciências Humanas da Universidade de São Paulo

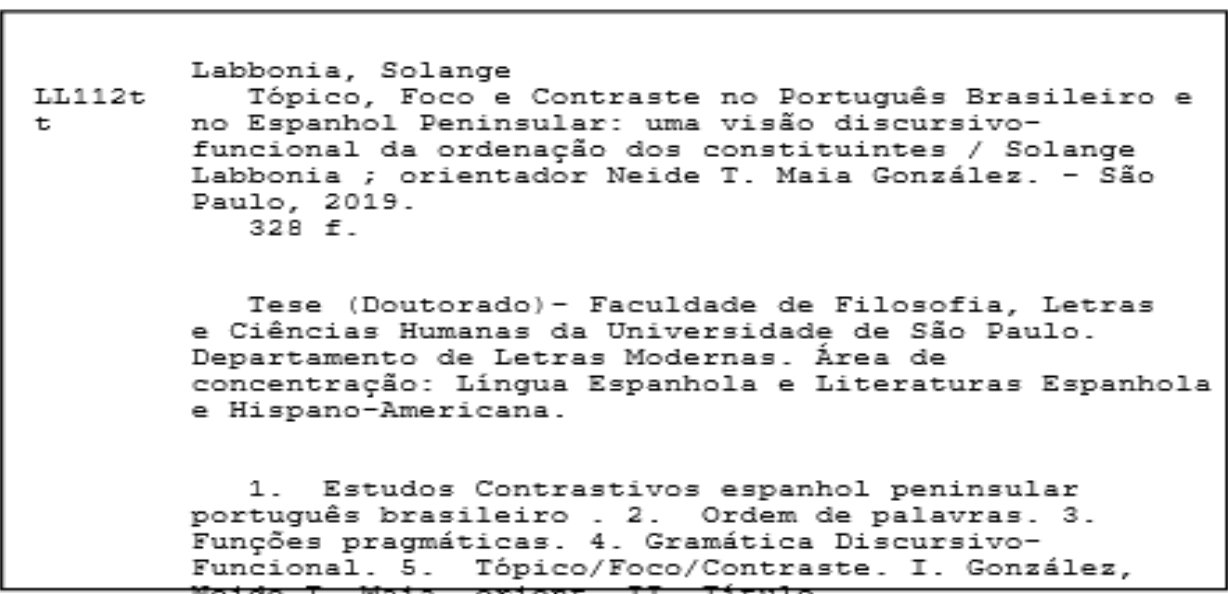

Euncional. 5. Tópico/Foco/Contraste. I. González, 


\section{ENTREGA DO EXEMPLAR CORRIGIDO DA TESE}

\section{Termo de Ciência e Concordância do (a) orientador (a)}

\section{Nome do (a) aluno (a): Solange Labbonia}

Data da defesa: 27/02/2019

Nome do Prof. (a) orientador (a): Neide T. Maia González

Nos termos da legislação vigente, declaro ESTAR CIENTE do conteúdo deste EXEMPLAR CORRIGIDO elaborado em atenção às sugestões dos membros da comissão Julgadora na sessão de defesa do trabalho, manifestando-me plenamente favorável ao seu encaminhamento e publicação no Portal Digital de Teses da USP.

São Paulo, 24/04/2019

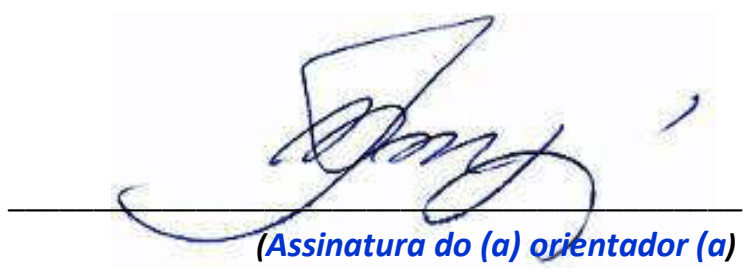




\section{AGRADECIMENTOS}

Ao Universo, Deus, ou essa energia que me guia a todo tempo e me deu e dá forças para seguir, para ser paciente nos momentos de aflição e ser dura nas difíceis decisões.

Aos meus pais, por serem meus maiores admiradores e inspiradores nesta jornada (da tese e da vida). Pai, cada lágrima sua me impulsionou! Obrigada, meu velho, por vibrar comigo e por mim mais do que se fosse por você mesmo. Mãezinha, obrigada por fazer comidinhas deliciosas e por dizer "vai dar certo". Obrigada aos dois por cada conversa no fim das tardes (nas que eram possíveis). Ao meu mano e aos meus sobrinhos, por entenderem que fui uma irmã e uma tia tão relapsa: Marcolino, obrigada por estar sempre disposto a me ajudar e ser meu parceiro nas horas boas e ruins. Ajudar na vida obviamente vai muito além de ajudar na tese. Amo vocês!

À minha mãe acadêmica e do coração, que amei desde as primeiras leituras quando ainda sua orientação era um sonho distante para mim: Neide, você sempre será meu exemplo! Obrigada pelo enorme respeito, pela generosidade, por aceitar o desafio de uma nova perspectiva teórica, por acreditar em mim, por respeitar meu ritmo de trabalho... obrigada pelo tempo dedicado, por abrir sua casa e por ser agente fundamental na realização deste sonho.

À professora Erotilde Pezatti, que só não foi a coorientadora deste trabalho por falta de organização de minha parte. A você, meus profundos agradecimentos pela imensa contribuição na banca de qualificação, pelos textos no prelo enviados e por responder sempre prontamente a todas as minhas dúvidas 
(que não foram poucas). Sem você este trabalho teria sido praticamente impossivel.

Aos professores Adrián Fanjul e Benivaldo Araújo Jr., pelas leituras atentas, discussões e contribuições. Também ao Adrián e à Maite Celada por sempre responderem nossas dúvidas e nos ajudarem em algumas traduções $e$ análises de exemplos. Ao professor Antonio Moreno Sandoval, por me receber na Universidad Autónoma de Madrid. À professora Heliana Mello, por me disponibilizar o corpus do C-ORAL-BRASIL. Infinitos agradecimentos também a todos os colegas e amigos hispanoparlantes que me ajudaram com os testes de aceitabilidade (não poderei citar todos aqui, pois a lista seria grande, mas sem a ajuda incrível de vocês tudo teria sido muitíssimo mais complicado!).

Aos amigos que estiveram comigo, longe ou perto, sempre com a bendita pergunta: "e a tese?". Aos que tentaram entender o que consumia meus dias, que foram compreensíveis com minhas ausências e que torceram por mim. Isa, você foi o presente que a USP me deu! Ana, minha bruxa, gracias por ter me reencontrado nessa vida. Lígia, você me ensina o que é ser amiga. Lari, obrigada por cruzar meu caminho e por todas as parcerias. Romy y Sory, gracias por lo linda que hicieron mi experiencia en Madrid. Elainne, Gus e Marcela, minha gratidão por nunca permitirem que eu me sentisse sozinha, mesmo estando em outros continentes. Todos vocês me mostram que, de fato, família vai muito além de laços sanguíneos.

À Tatiani Zorzetto, pela empatia ímpar e pela ajuda imensa com as passagens de avião. Sem você, sair de Chapecó às quartas de madrugada e estar na aula em SP quinta à tarde teria um pouco mais complicado do que foi rsrs! Ao Rafa, por me auxiliar com os áudios e com as imagens. Pessoas como vocês nos fazem acreditar que ainda há bondade no mundo. 
À Universidade Federal da Fronteira Sul, pelo tempo de afastamento concedido para a realização de parte deste trabalho e por apoiar minha formação docente. A todos os funcionários da Universidade de São Paulo, especialmente da FFLCH, por me auxiliarem nos processos burocráticos e serem sempre tão gentis.

A todos meus colegas de profissão, que me apoiaram durante esse período intenso de tese: agora não escapo mais de compor as comissões!

A todos os meus alunos, que sempre foram e são minha maior inspiração para seguir buscando respostas.

Às minhas pequenas, Rebeca e Anita, companheirinhas incansáveis. Vocês nunca vão ler isso, mas sabem que são minhas alegrias.

A todos os envolvidos direta ou indiretamente neste trabalho, minha infinita gratidão!! 
A viagem não termina jamais. Só os viajantes terminam. E também eles podem subsistir em memória, em lembrança, em narração... $O$ objectivo de uma viagem é só o início de outra viagem. (José Saramago) 


\title{
RESUMO
}

\begin{abstract}
LABBONIA, Solange. Tópico, Foco e Contraste no Português Brasileiro e no Espanhol Peninsular: uma visão discursivo-funcional da ordenação dos constituintes. São Paulo, 2019. 328 f. Tese (Doutorado em Língua Espanhola) Faculdade de Filosofia, Letras e Ciências Humanas, Universidade de São Paulo.
\end{abstract}

Este trabalho descreve, analisa e compara, no espanhol peninsular (EP) e no português brasileiro (PB), as estratégias de ordenação dos constituintes de Propriedade Configuracional (argumentais) ou correferenciais a eles, e que portam funções pragmáticas (Tópico, Foco e Contraste) ou retóricas (Orientação e Esclarecimento). O referencial teórico desta pesquisa é o da Gramática Discursivo-Funcional - GDF (HENGEVELD \& MACKENZIE, 2008; MACKENZIE, 2012; PEZATTI, 2014, 2017) e o dos estudos comparativos entre o PB e o E (GONZÁLEZ, 1994, 2008, 2014; GROPPI, 2004; FANJUL, 2014; PINHEIRO-CORREA, 2015, 2018). A unidade de análise selecionada é o Ato Discursivo, o que significa que são considerados tanto constituintes oracionais como extraoracionais. Dentre os oracionais, os analisados são os de sentenças simples de llocuções Declarativas e Interrogativas e de Estado-de-Coisas [+dinâmicos]. Com base nos objetivos e no referencial teórico desta pesquisa, se analisa dois subcorpora de língua oral coloquial, um extraído do projeto C-ORALROM, que contempla a variedade de Madri, e outro do C-ORAL-BRASIL, que contempla a variedade mineira. A hipótese central que se tratou de comprovar é a de que, para enunciados que não sejam contrastivos, o EP se caracteriza pela não topicalização dos Sujeitos e topicalização dos Objetos, em um processo oposto ao que ocorre em PB, que prefere topicalizar os Sujeitos e não topicalizar os Objetos. Considerando a perspectiva discursivofuncional elegida neste estudo, toma-se por base que cada posição do Enunciado tende a ser ocupada por diferentes tipos de constituintes. Para analisar quais são as preferências, motivações e limitações para os posicionamentos de constituintes com as funções pragmáticas e retóricas supracitadas, são investigados fatores como (i) a relação entre determinação/especificidade/genericidade e Tópico/Foco, e as consequências dessa relação no Nível Morfossintático de cada língua, tais como duplicações por clíticos ou por pronomes fortes, não realização versus realização de Sujeitos pronominais, etc.; (ii) estruturas especiais para a marcação de Foco e de Contraste em ambas as línguas, principalmente as obtidas exclusivamente pela ordenação; (iii) os tipos de respostas dadas às sentenças Interrogativas Polares e a posição dos constituintes nas Interrogativas de Conteúdo. A tese está dividida em duas grandes partes: a primeira concentra as bases do referencial teórico escolhido e apresenta os procedimentos metodológicos adotados; a segunda mescla teoria, descrição e análises dos dados dos corpora. Os resultados evidenciam variadas diferenças entre as línguas, tanto no que se refere à ordenação quanto a outras estratégias usadas, a depender da função sintática dos constituintes aos quais se atribuem as funções pragmáticas e retóricas. Algumas vezes os mesmos recursos estão disponíveis em ambas as línguas, mas diferem entre si pelo grau de preferencialidade entre uns e outros. Outras vezes, uma língua recorre a estratégias que não estão disponíveis na outra. De maneira geral, o sistema de esquemas de posições proposto pela GDF possibilitou entender que estruturas superficialmente iguais podem ser diferentes em sua funcionalidade.

Palavras-chave: ordem de palavras. Tópico. Foco. Contraste. Funções pragmáticas. Estudos Contrastivos espanhol peninsular-português brasileiro. Gramática Discursivo-Funcional (GDF). 


\title{
ABSTRACT
}

\author{
LABBONIA, Solange. Topic, Focus and Contrast in Portuguese and in Peninsular \\ Spanish: a functional discourse view of the constituents ordering. São Paulo, \\ 2019. 328 f. Tese (Doutorado em Língua Espanhola) - Faculdade de Filosofia, Letras \\ e Ciências Humanas, Universidade de São Paulo.
}

This work describes, analyzes and compares, in Peninsular Spanish (PS) and in Brazilian Portuguese (PB), the ordering strategies of the Configurational Property constituents (argumental) or co-referential to them and that carry pragmatic functions (Topic, Focus and Contrast) and rhetorical functions (Orientation and Clarification). The theoretical reference of this research is the Functional Discourse Grammar - FDG (HENGEVELD \& MACKENZIE, 2008; MACKENZIE, 2012; PEZATTI, 2014, 2017) and the comparative studies between BP and S (GONZÁLEZ, 1994, 2008, 2014; GROPPI, 2004; FANJUL, 2014; PINHEIRO-CORREA, 2015, 2018). The unit of analysis selected is the Discourse Act, which means that they are considered both in the clause scope constituents and in the linguistic expression constituents. Among the clause scope ones, the analyzed are those of simple sentences of Declarative and Interrogative llocutions and of State-of-Affairs [+dynamic]. Based on the objectives and the theoretical reference of this research, what are analyzed are two subcorpora of colloquial oral language extracted from the project C-ORAL-ROM, that contemplates the variety of Madrid, and CORAL-BRASIL, that contemplates the Minas Gerais State's variety. The central hypothesis that was sought to be confirmed was the one that, for statements that are not contrastive, the PS is characterized by the non-topicalization of the Subjects and by the topicalization of the Objects, in an opposite process to what occurs in BP, which tends to topicalize the Subjects and nontopicalize the Objects. Considering the functional discourse perspective chosen in this study, it is assumed that each position of the Statement tends to be occupied by different types of constituents. In order to analyze the preferences, motivations and limitations for constituents positions with the aforementioned pragmatic and rhetorical functions, factors such as (i) the relation between determination/specificity/genericity and Topic/Focus are investigated, as well as the consequences of this relation in Morphosyntactic level of each language, such as clitic doublings or strong pronouns, no materialization or materialization of pronominal Subjects, etc.; (ii) special structures for Focus and Contrast marking in both languages, especially those obtained exclusively by ordination; (iii) the types of responses given to the Polar Interrogative sentences and the position of the constituents in the Content Interrogatives. The thesis is divided in two major parts: the first one concentrates the bases of the chosen theoretical reference and methodological questions and the second one merges theory, description and results of the analysis of data obtained from corpora. The results show several differences between languages, both in terms of ordering and other strategies used, depending on the syntactic function of the constituents to which pragmatic and rhetorical functions are attributed. Sometimes the same resources are available in both languages, but they differ by the degree of preference between them. At other times, one language resorts to strategies that are not available in the other. In general, the system of position schemes proposed by FGD has made it possible to understand that apparently equal structures on the surface may be different in their functionality.

Keywords: words order. Topic. Focus. Contrast. Pragmatic functions. Peninsular SpanishBrazilian Portuguese contrastive studies. Functional Discourse Grammar (FDG). 


\title{
RESUMEN
}

\author{
LABBONIA, Solange. Tópico, Foco y Contraste en el Portugués de Brasil y en el \\ Español Peninsular: una mirada discursivo-funcional de la ordenación de los \\ constituyentes. São Paulo, 2019. 328 f. Tese (Doutorado em Língua Espanhola) - \\ Faculdade de Filosofia, Letras e Ciências Humanas, Universidade de São Paulo.
}

Este trabajo describe, analiza y compara, en el español peninsular (EP) y en el portugués brasileño (PB), las estrategias de ordenación de los constituyentes de Propiedad Configuracional (argumentales) o correferenciales a ellos, y que portan funciones pragmáticas (Tópico, Foco y Contraste) o retóricas (Orientación y Esclarecimiento). El referencial teórico de esta investigación es el de la Gramática Discursivo-Funcional - GDF (HENGEVELD \& MACKENZIE, 2008; MACKENZIE, 2012; PEZATTI, 2014, 2017) y el de los estudios comparados entre el PB y el E (GONZÁLEZ, 1994, 2008, 2014; GROPPI, 2004; FANJUL, 2014; PINHEIRO-CORREA, 2015, 2018). La unidad de análisis seleccionada es el Acto Discursivo, lo que significa decir que se consideran tanto constituyentes oracionales como extraoracionales. De los oracionales, los que se analizan son los de sentencias simples de Ilocuciones Declarativas e Interrogativas y de Estados-de-Cosas [+dinámicos]. Tomando por base los objetivos y el marco teórico de esta investigación, se analizan dos subcorpus de lengua oral coloquial, uno extraído del proyecto C-ORAL-ROM, que contempla la variedad de Madrid, y otro del C-ORAL-BRASIL, que contempla la variedad de Minas Gerais (BR). La hipótesis central que se buscó comprobar es la de que, para enunciados que no son contrastivos, el EP se caracteriza por no topicalizar los Sujetos y por topicalizar los Objetos, en un proceso inverso al que ocurre en PB, que prefiere topicalizar sus Sujetos y no topicalizar los Objetos. Teniendo en cuenta la perspectiva discursivo-funcional elegida para este estudio, se toma como base que cada posición del Enunciado tiende a ser ocupada por diferentes tipos de constituyentes. Para analizar cuáles son las preferencias, motivaciones y limitaciones para los posicionamientos de los constituyentes ya mencionados, se investigan factores tales como (i) la relación entre determinación/especificidad/genericidad y Tópico/Foco, y las consecuencias de esa relación en el Nivel Morfosintáctico de cada lengua, tales como duplicaciones por clíticos o por pronombres fuertes, no realización versus realización de Sujetos pronominales, etc.; (ii) estructuras especiales para la marcación de Foco y de Contraste en ambas lenguas, principalmente las obtenidas por la ordenación; (iii) los tipos de respuestas dadas a las sentencias Interrogativas Polares y la posición de los constituyentes en las Interrogativas de Contenido. La tesis está dividida en dos grandes partes: la primera concentra las bases del marco teórico elegido y presenta los procedimientos metodológicos adoptados; la segunda mezcla teoría, descripción y análisis de los datos de los corpus. Los resultados evidencian variadas diferencias entre las lenguas, tanto en lo que se refiere a la ordenación como a otras estrategias usadas, según la función sintáctica de los constituyentes a los cuales se atribuyen las funciones pragmáticas y retóricas. Algunas veces los mismos recursos están disponibles en ambas lenguas, pero se diferencian por el grado de preferencia que presenta cada una por uno u otro. Otras veces, una lengua se vale de estrategias que no están disponibles en la otra. De modo general, el sistema de esquemas de posiciones propuesto por la GDF hizo posible entender que estructuras superficialmente iguales pueden ser distintas en su funcionalidad.

Palabras-clave: orden de palabras. Tópico. Foco. Contraste. Funciones pragmáticas. Estudios Contrastivos español peninsular-portugués de Brasil. Gramática DiscursivoFuncional (GDF). 


\section{LISTA DE FIGURAS, GRÁFICOS E ESQUEMAS}

\section{FIGURAS}

FIGURA 1 - EXEMPLO ADAPTAÇÃO DA FICHA DE METADADOS DO C-ORAL-ROM . .44

FIGURA 2 - CONVENÇÕES DAS ETIQUETAGENS PROSÓDICAS NAS TRANSCRIÇÕES NO CORAL-ROM .46

FIGURA 3 - CONVENÇÕES DAS ETIQUETAGENS DE TURNOS E ELEMENTOS PARALINGUÍSTICOS

FIGURA 4 - EXEMPLO DE TRANSCRIÇÃO ORTOGRÁFICA NO C-ORAL-ROM ………...........48

FIGURA 5 - TELA DE ALINHAMENTO NO DVD C-ORAL-ROM ......................................50

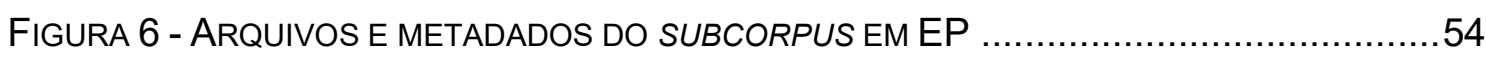

FIGURA 7 - EXEMPLO DE ADAPTAÇÃO DA FICHA DE METADADOS DO C-ORAL-BRASIL .......56

FIGURA 8 - EXEMPLO DE TRANSCRIÇÃO DO C-ORAL-BRASIL .......................................57

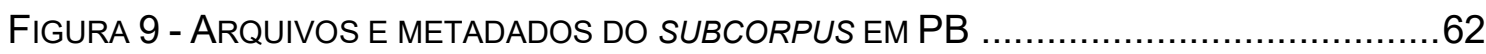

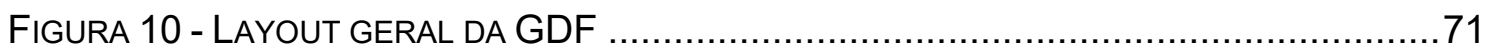

FIGURA 11 - ESBOÇO MODIFICADO DO LAYOUT GERAL DA GDF ................................74

FIGURA 12 - EXEMPLO DE ORDENAÇÃO DE CONSTITUINTES HIERÁRQUICOS .....................121

FIGURA 13 - FOLHETO PUBLICITÁRIO ¿QUÉ HACE USTED FELIZ? ..................................296

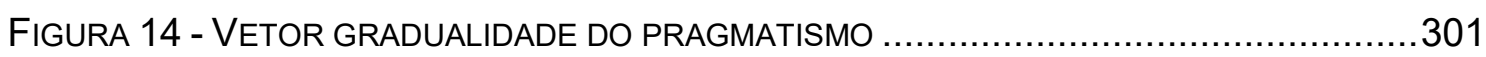

\section{GRÁFICOS}

GRÁFICO 1 - OCORRÊNCIAS ORDENAÇÕES VS / OVS /VOS EM EP E EM PB EM NOSSOS

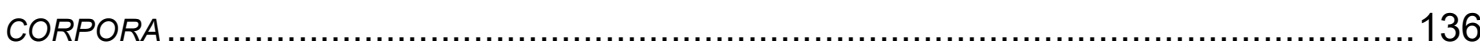

GRÁFICO 2 - VERBOS COM SUJEITO POSPOSTO MAIS FREQUENTES NOS DADOS DO EP ...202 GRÁFICO 3 - VERBOS COM SUJEITO POSPOSTO NOS DADOS EM PB ..............................203 GRÁFICO 4 - SUJEITOS PRONOMINAIS X SUJEITOS NULOS EM EP …….........................231 GRÁFICO 5 - TIPOS DE PRONOMES EM SUJEITOS PRONOMINAIS NO EP..........................233 


\section{ESQUEMAS}

ESQUEMA 1 - - HIERARQUIA DOS NÍVEIS DO COMPONENTE GRAMATICAL.........................76

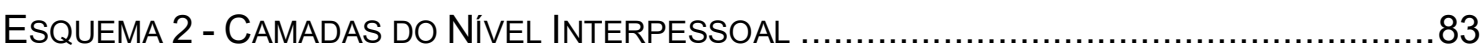

ESQUEMA 3 - CAMADAS Do NíveL REPRESENTACIONAL ..........................................

ESQUEMA 4 - Molde de PREDICAÇÃO de PROPRIEDADES DE PREDICAÇÃO dE UM LUGAR.. 96

ESQUEMA 5 - POSIÇÕES DOS CONSTITUINTES DE PROPRIEDADES CONFIGURACIONAIS DE

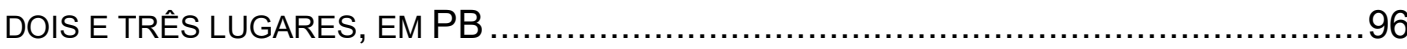

ESQUEMA 6 - POSICIONAMENTO DOS CONSTITUINTES ARGUMENTAIS E SUAS RESPECTIVAS

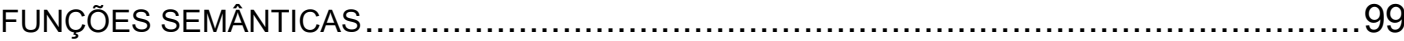

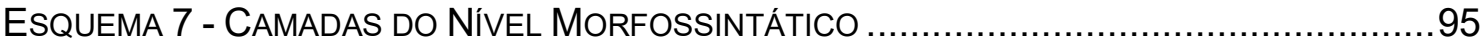

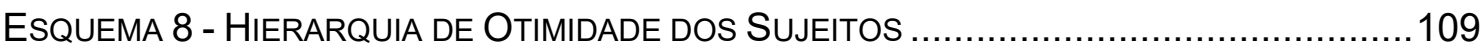

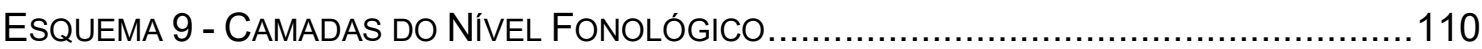

ESQUEMA 10 - HIERARQUIA DE TODAS AS CAMADAS DOS QUATRO NíVEIS DA GDF ..........111

ESQUEMA 11 - ESQUEMA DE ORDENAÇÃO DOS CONSTITUINTES .................................122

ESQUEMA 12 - PosIçÕES ABSOLUTAS E RELATIVAS dOS CONSTITUINTES NA ORAÇÃO .....123

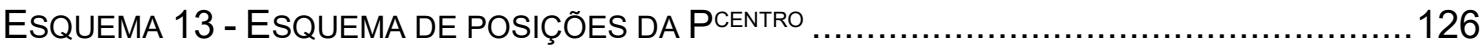

ESQUEMA 14 - ESQUEMA DE POSICIONAMENTO NA EXPRESSÃO LINGUÍSTICA...................126

ESQUEMA 15 - TIPOS DE CONSTITUINTES QUE PODEM OCUPAR CADA POSIÇÃO..................127

ESQUEMA 16 - PREENCHIMENTO DAS POSIÇÕES PELOS CONSTITUINTES SELECIONADOS PARA ANÁLISE 132

ESQUEMA 17 - VETOR DO ESQUEMA DE PREENCHIMENTO DAS POSIÇÕES ......................133

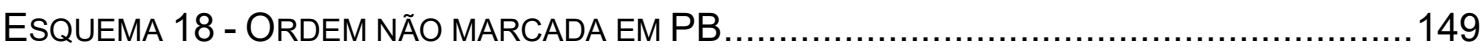

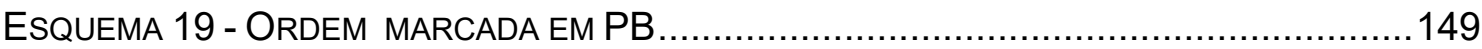

ESQUEMA 20 - ORIENTAÇÃO CENTRÍPETA DOS CONSTITUINTES..................................178

ESQUEMA 21 - INTERPRETAÇÃO DISCURSIVA DA ORDEM OVS EM EP ……..................188

ESQUEMA 22 - ESTRATÉGIAS DE FOCALIZAÇÃO EM PB E EM EP ...................................209

ESQUEMA 23 - ESTRATÉGIAS DE FOCALIZAÇÃO USADAS EM PB .................................210

ESQUEMA 24 - ESTRATÉGIAS DE FOCALIZAÇÃO USADAS EM EP .................................210

ESQUEMA 25 - SínTESE COMPARATIVA DAS SENTENÇAS TÉTICAS E SEMI-TÉTICAS ............211

ESQUEMA 26 - PREFERÊNCIAS DE RECURSOS DE CADA LÍNGUA PARA CONSTRUIR SENTENÇAS

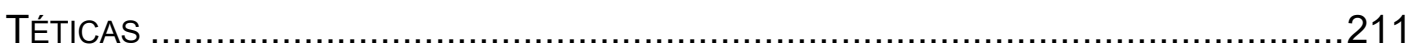

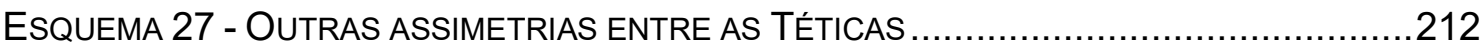

ESQUEMA 28 - ORDENAÇÕES DE CONSTITUINTES CONTRASTADOS ................................229 
ESQUEMA 29 - TENDÊNCIAS DE NÃO TOPICALIZAÇÃO NAS DUAS LÍNGUAS .......................239

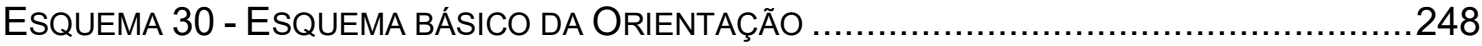

ESQUEMA 31 - TIPOS DE ANÁFORAS NOS ENUNCIADOS COM ORIENTAÇÕES.....................265

ESQUEMA 32 - ESQUEMA BÁSICO DO ESCLARECIMENTO …...................................267

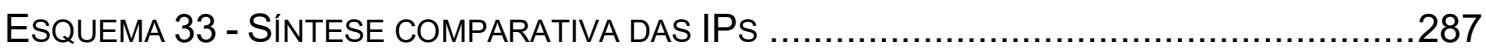

ESQUEMA 34 - PROPOSTA DE POSICIONAMENTO PARA CONSTITUINTES PRAGMÁTICOS NAS

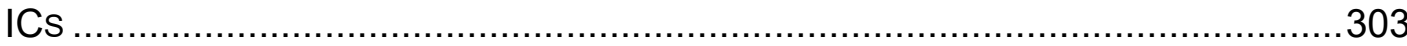

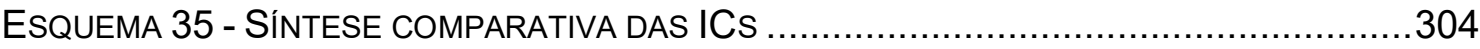




\section{LISTA DE ABREVIATURAS, SIGLAS E SÍMBOLOS}

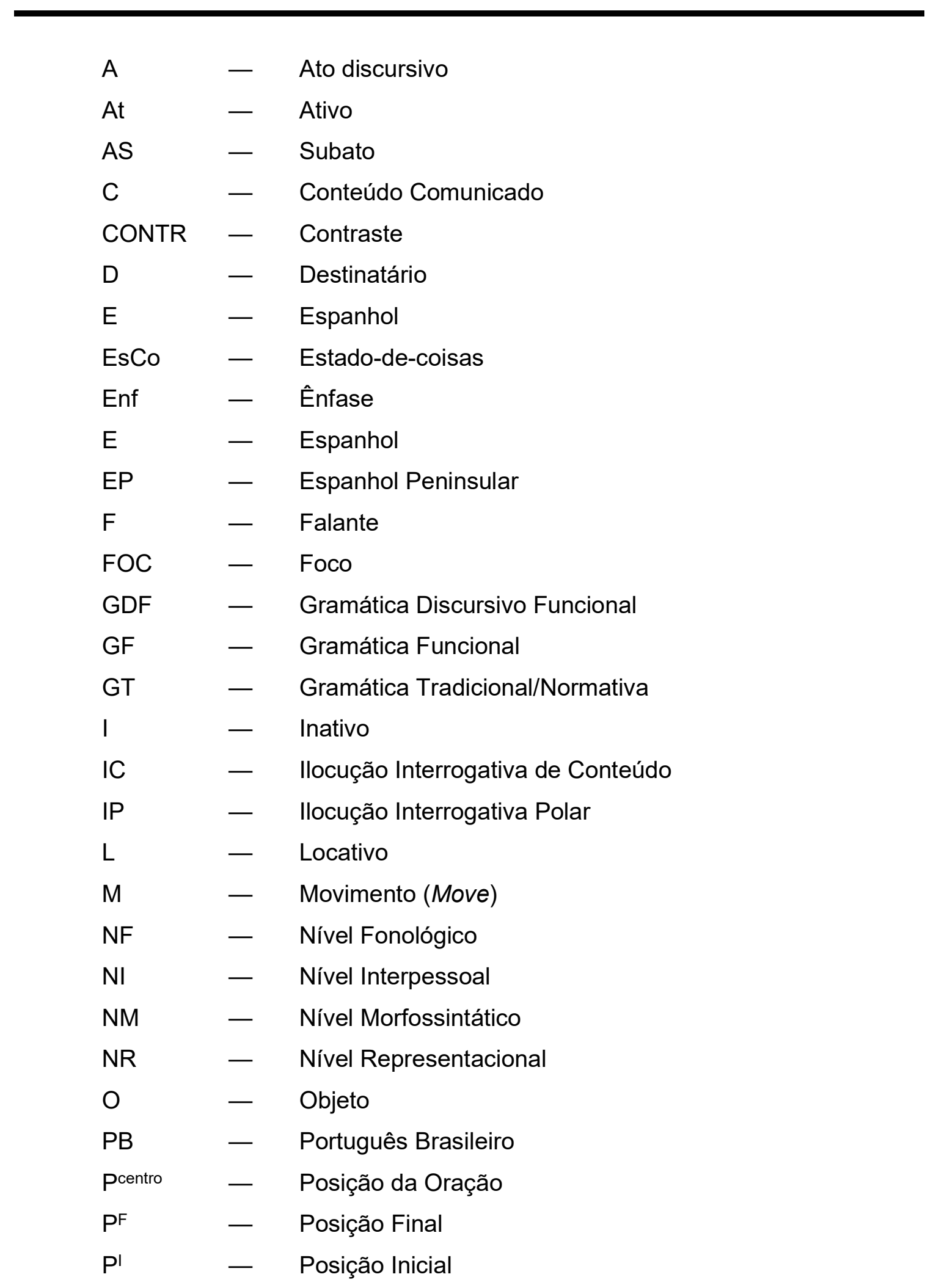




$\begin{array}{lll}\mathrm{P}^{\mathrm{M}} & - & \text { Posição medial/média } \\ \text { Pos } & - & \text { Posição pós-oracional } \\ \text { Pre } & - & \text { Posição pré-oracional } \\ \text { S } & - & \text { Sujeito } \\ \text { SOV } & - & \text { Sujeito-objeto-verbo } \\ \text { SVO } & - & \text { Sujeito-verbo-objeto } \\ \text { TOP } & - & \text { Tópico } \\ \text { V } & - & \text { Verbo } \\ \text { VS } & - & \text { Verbo-Sujeito }\end{array}$




\section{Sumário}

INTRODUÇÃO - DAS MOTIVAÇÕES E DOS PERCURSOS E PERCALÇOS........20

PARTE I: SUPORTE TEŐRICO E METODOLOG|A...............................26

CAPÍTULO ZERO - PROLEGÔMENOS TEÓRICOS: DA ORDEM SINTÁTICA À

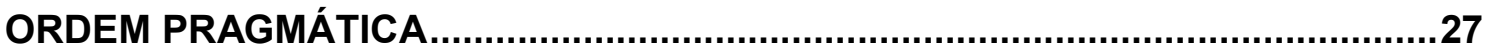

0.1 REVISÃo TEÓRICA E BIBLIOGRÁFICA SOBRE O ESPANHOL ............................27

0.2 REVISÃo TEÓRICA E BIBLIOGRÁFICA SOBRE O PORTUGUÊS ................................ 35

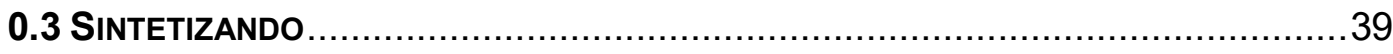

CAPÍTULO 1 - OS PROJETOS C-ORAL-ROM E C-ORAL BRASIL .......................41

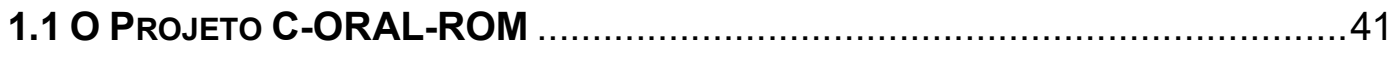

1.1.1 A língua espanhola no C-ORAL-ROM ........................................... 51

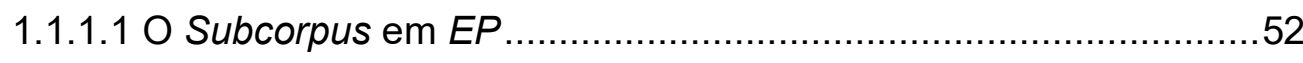

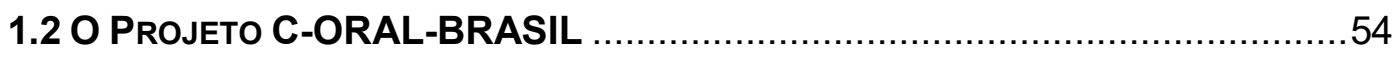

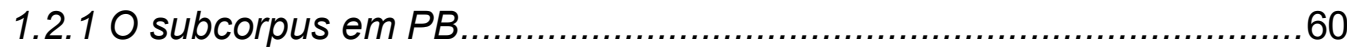

1.3 OUTROS PROCEDIMENTOS METODOLÓGICOS ADOTADOS …..............................63

\section{CAPÍTULO 2 - ARQUITETURA GERAL DA GRAMÁTICA DISCURSIVO-}

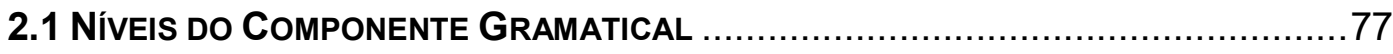

2.1.1 Nivel Interpessoal (NI) ............................................................

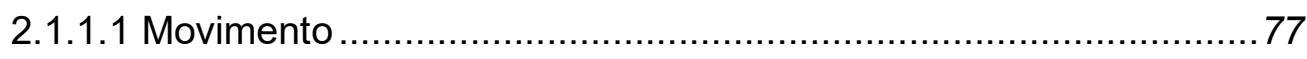

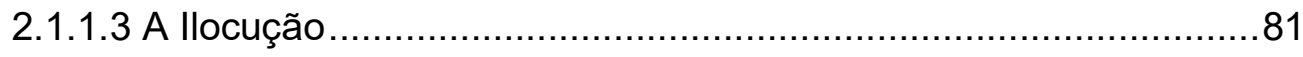

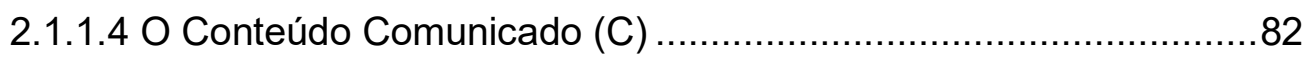




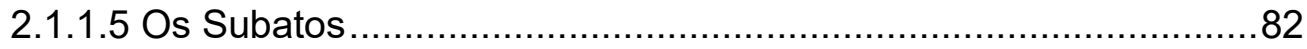

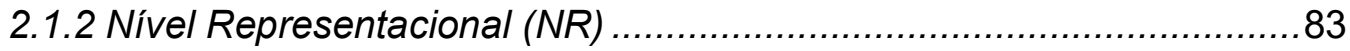

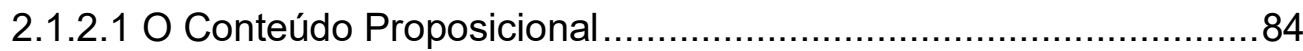

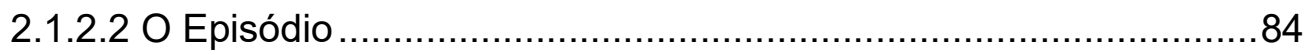

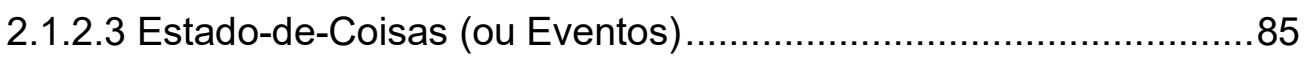

2.1.2.4 Propriedade Configuracional .................................................. 86

2.1.2.a. As funções semânticas na GDF ..........................................92

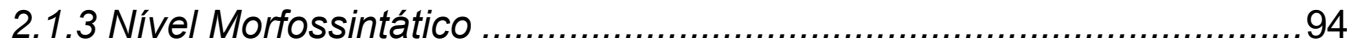

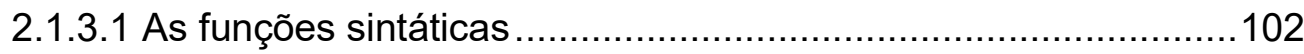

2.1.4 Nível Fonológico...................................................................... 110

\section{CAPÍTULO 3 - A ORDENAÇÃO DOS CONSTITUINTES NA GDF........................112}

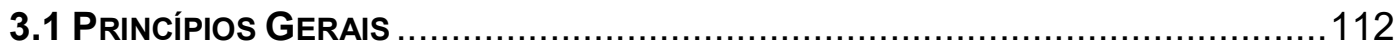

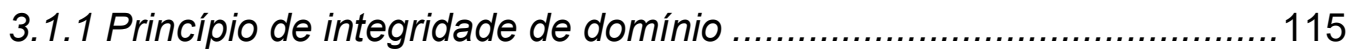

3.1.2 Princípio de ordenação icônica....................................................115

3.1.2.1 Subprincípio de ordenação sequencial ....................................116

3.1.2.2 Subprincípio da quantidade .................................................116

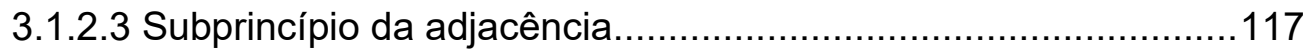

3.1.3 Princípio da Preservação das Relações de Escopo ..........................118

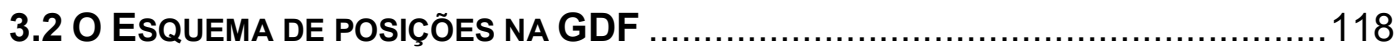

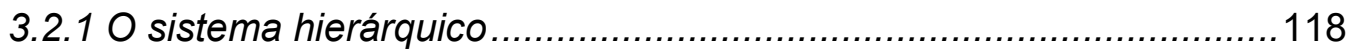

3.2.2.1 Ordenação dos constituintes hierárquicos...............................119

3.2.2.2 Alinhamento dos constituintes não hierárquicos........................127 
PARTE II = FUNCOÕES PRAGMIÁTICAS E RETÖRICAS E SUAS REALIZACOOOES EMI PB E EMI EP.

\section{CAPÍTULO 4 - AS FUNÇÕES PRAGMÁTICAS DE TÓPICO, FOCO E CONTRASTE}

4.1. Eso lo veo dificil $x$ Isso eu acho difícil: a função Tópico ...................138

4.1.2 Os Tópicos Duplicados 156

4.2 EU TENHO É SÓ VERGONHA X LO ÚNICO QUE TENGO ES VERGÜENZA: A FUNÇÃO Foco. 171

4.2. 1 Noções gerais. 171

4.2. 2 A estratégia do Foco-ser na marcação de Foco em PB 174

4.2. 3 A ordenação dos constituintes na marcação de Foco 182

4.2.4 Ainda os enunciados Téticos 191

4.2.4.1 As construções Téticas em E com dativos afetados 204

4.3 Esse eu nunca vi $x$ A ese no lo he visto nunca: a função Contraste 212

4.3.1 Noções gerais. 212

4.3.3 Breve nota sobre as sentenças clivadas (escindidas) ......................215

4.3.3 Ordem dos constituintes para a atribuição de Contraste ....................220

4.3.4 Sujeitos plenos x Sujeitos nulos na marcação de Contraste ..............230

4.4 Ênfase. 240

CAPÍTULO 5 - AS FUNÇõES RETÓRICAS DE ORIENTAÇÃO E DE ESCLARECIMENTO 246

5.1 As pilhas, eu coloquei aqui x Las pilas, las coloqué aquí: a função Orientação. 248

5.2 Tão sendo muito legais, as aulas / Está perdiendo la audiencia ya, el programa: a função Esclarecimento 


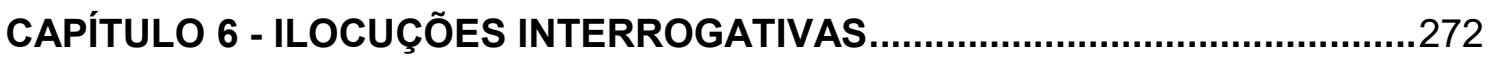

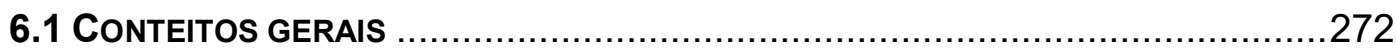

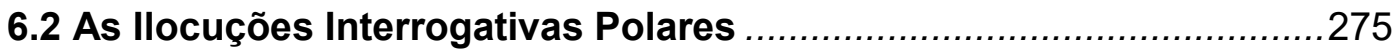

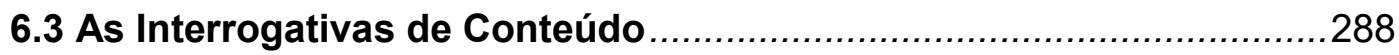

6.3.1 A hipótese da gradualidade de pragmatismo

CAMINHANDO RUMO ÀS CONSIDERAÇÕES FINAIS......................................305

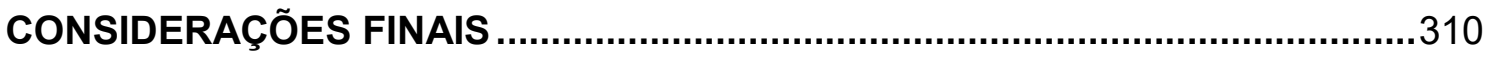

BIBLIOGRAFIA E REFERÊNCIAS BIBLIOGRÁFICAS CONSULTADAS .............319 


\section{INTRODUÇÃO}

\section{DAS MOTIVAÇÕES E DOS PERCURSOS E PERCALÇOS}

Várias vertentes teóricas linguísticas têm classificado o português brasileiro $(\mathrm{PB})^{1}$ e o espanhol peninsular (EP) como línguas do tipo SVO (Sujeito-Verbo-Objeto), argumentando ser essa a ordem mais frequente e menos marcada nas duas línguas, com sentenças como as seguintes:

(1) Ana fez o bolo.

(2) Ana hizo el pastel.

Pareceria, a partir dessa perspectiva, que a ordenação dos constituintes oracionais ocorre da mesma maneira nos dois idiomas e que essa seria mais uma simetria entre as línguas hermanas. Porém, em minha prática como professora de língua espanhola para brasileiros, percebi, em uma das aulas, que os alunos estavam com dificuldades para interpretar e responder a um exercício que trazia a seguinte sentença: ¿A quién ha visto Juan? Os alunos interpretavam o termo Juan como complemento (objeto direto) do verbo e eu lhes expliquei que em espanhol era comum que o Sujeito viesse após o verbo, como nesse caso em que, por tratar-se de uma pergunta, a posposição é obrigatória. Comecei a perceber, também, que em suas produções escritas e orais, apareciam estruturas como ¿Quién Juan vio? e (quase) nunca apareciam estruturas como Este cartel lo hice yo ou A mi madre le regalé unos pantalones.

Esses e outros casos observados durante minha trajetória de professora de espanhol como língua estrangeira (ELE), portanto, começaram a me indicar que a

\footnotetext{
${ }^{1}$ Embora alguns dos trabalhos consultados (dentre eles os de PEZATTI, 1994, 2012, 2014) falem sobre outras variedades do português, me limitarei ao que genericamente vem se designando como PB. Tenho, no entanto, clareza que é uma denominação extremamente abrangente, dada sua imensa variação regional. Especificamente, optei por fazer um recorte nos dados do PB, selecionando para nossa análise um corpus de Minas Gerais. O mesmo vale para o espanhol, pois das diversas variedades/variantes, selecionei a peninsular, da cidade de Madri. Essas escolhas deveram-se ao fato de tratar-se de dois corpora comparáveis já constituídos nas duas línguas, como explicarei no primeiro capítulo.
} 
maneira de ordenar as palavras é um fator que pode ter efeitos que vale a pena observar e analisar na aprendizagem do espanhol como língua estrangeira e que meus alunos, em sua maioria brasileiros tendo o português como língua materna, ${ }^{2}$ estavam, com frequência, reproduzindo a ordenação do português em suas produções em espanhol como LE. Nasceu daí, da sala de aula e do embate português/espanhol, um tema que merecia um olhar mais cuidadoso e respostas mais adequadas. Surgiu, assim, o projeto para a presente pesquisa, cujo primeiro grande objetivo era comparar a ordenação das palavras nessas duas línguas, com foco nos efeitos que pudessem deixar nas produções de alunos brasileiros de ELE. Desse modo, embora esta tese não possa se dedicar a estudar o processo de aquisição/aprendizagem dessas construções, foram fatos como os que acabo de descrever que motivaram a realização deste estudo comparativo.

Quando apresentei o projeto, ainda na seleção para o Doutorado, o objetivo era analisar produções orais desses alunos, descrevendo questões relacionadas à ordenação das palavras, com fortes hipóteses de que apareceriam dados de interlíngua relacionados a esse aspecto. Com o projeto já aprovado e com a pesquisa em fase inicial, fui colaboradora em um projeto de extensão de Teletandem, ${ }^{3}$ coordenado pela professora Larissa Tirloni, em que um grupo de aproximadamente 20 alunos da universidade em que trabalho e na qual a professora Tirloni era substituta na época (a UFFS), estudantes do curso de Letras Português/Espanhol, conversavam com outros 20 alunos da Universidad Autónoma de México (UNAM), alunos do curso de português para estrangeiros. Assim, tínhamos um grupo de hispanoparlantes mexicanos que estavam aprendendo português como LE e um grupo de lusófonos brasileiros que estavam aprendendo espanhol como LE. Esse grupo se encontrava virtualmente via Skype, nos laboratórios das respectivas universidades, e os

\footnotetext{
${ }^{2}$ Essa observação pode parecer um pouco óbvia, mas é muito pertinente quando se refere à região Sul do país, onde há muitos descendentes de italianos e de alemães (às vezes, portanto, bilíngues ou com línguas maternas que não o português), e que, justamente, configura a realidade de uma parte considerável de meus alunos.

${ }^{3} \mathrm{~A}$ palavra tandem designa uma bicicleta usada simultaneamente por duas pessoas que pedalam em direção ao mesmo destino. Por analogia a essa mútua colaboração de pedalar a bicicleta, a partir de 1994, esse termo passou a designar, também, uma forma de aprendizagem colaborativa de línguas estrangeiras, em que os aprendizes de uma língua estrangeira entram em contato com falantes já proficientes nessa língua alvo. O tandem pode ser presencial (face a face) ou à distância (teletandem ou etandem). Este último é realizado através de meios eletrônicos como e-mail, chat, Skype, telefone, videoconferências, whatsapp, ou outro meio de comunicação.
} 
participantes conversavam durante uma hora, sendo meia hora em português e meia hora em espanhol.

Pedi autorização para todos os alunos para gravar as conversas, explicandoIhes que se tratava de um projeto de pesquisa. Redigi termos de consentimento e todos assinaram (inclusive os alunos mexicanos, que depois me enviaram os documentos digitalizados). Foi um processo um pouco complicado conseguir gravar todas as interações, mas o que se tornou realmente inviável foi fazer as transcrições desse material. Procurei alternativas de softwares que já transcreviam os áudios, mas não ficavam com uma qualidade aceitável, o que me fez entender que esse caminho precisaria ser abandonado.

Foi quando, em uma das disciplinas que cursei na USP, o professor Adrián Fanjul me sugeriu um recorte na pesquisa: descrever a ordenação nas duas línguas, mas sem analisar produção não nativa, ou seja, não analisar produções de alunos. Com o início das pesquisas teóricas e com as conversas com a orientadora da pesquisa, fui percebendo que realmente a ideia inicial estava muito ampla. Decidi, então, não analisar produção não nativa, ao menos nesta etapa de doutorado. Um novo desafio surgia: encontrar um corpus que fosse oral e que pudesse ser comparável nas duas línguas (em termos quantitativos, de gênero discursivo-textual, de critérios de gravação, de grupos sociais que compunham os informantes, etc.).

A sugestão dada pela orientadora foi que, para os dados em espanhol, eu usasse o PRESEEA (Proyecto para el estudio sociolingüístico del español de España y de América), que havia sido usado por um de seus orientandos, o prof. Benivaldo José de Araújo Jr., que inclusive gentilmente me forneceu todo o corpus. E para os dados em português, a sugestão foi o GESOL-USP (Grupo de Estudos de Sociolinguística). Até esse momento, não havia definido ainda meu referencial teórico. Confesso que o percurso, nesse sentido, foi bastante longo, durante o qual oscilei entre as várias possibilidades: comecei a ler sobre aquisição da linguagem, passei por teorias gerativistas, revisei a gramática normativa, cheguei ao funcionalismo e, por fim, encontrei (e fui adotando) a Gramática Discursivo-Funcional. Digo que fui adotando, assim, no gerúndio mesmo, porque na banca de qualificação ainda persistiam uns deslocamentos à esquerda e outras ideias que aos poucos fui tratando de desinternalizar (com muita ajuda da professora Erotilde Pezatti, aliás, a quem devo infinitos agradecimentos nessa trajetória). 
Ao analisar esses corpora, mas já com uma clara inclinação a preservar fatores discursivos e pragmáticos das interações, comecei a procurar algum corpus oral que fosse mais livre, ou seja, que tivesse a menor intervenção possível de um entrevistador e que não tivesse nenhum roteiro a ser seguido, ou seja, que fosse real/ usual. Foi então que, pesquisando, encontrei por um acaso na internet o projeto CORAL-ROM (Integrated Reference Corpora for Spoken Romance Languages) e logo depois encontrei o C-ORAL-BRASIL: eu tinha agora corpora paralelos, com os mesmos critérios aos quais me referi acima, que me parecia o mais justo (igualitário e, portanto, com maior possibilidade de fidelidade à realidade, ainda com todas as limitações) para um estudo comparado como o que eu estava propondo.

Depois de um longo caminho percorrido e de alguns tantos percalços, como tracei aqui brevemente, consegui, por fim: (i) delimitar muito globalmente meu primeiro objetivo (estudar a ordenação das Palavras, ${ }^{4}$ de maneira comparativa, em PB e em E); (ii) definir a linha teórica adotada; e (iii) escolher os corpora que me pareciam adequados aos objetivos propostos. Faltava-me, ainda, especificar (recortar) o objetivo, que estava extremamente abrangente. Logicamente, as várias leituras feitas sobre o assunto foram essenciais nesse processo.

Por isso, apresento a seguir o que chamei de Capítulo Zero ou Prolegômenos teóricos, por serem apenas algumas considerações preliminares de cunho teórico que me ajudaram a delimitar os objetivos deste trabalho. Não apresento, ainda, a perspectiva teórica adotada, que será descrita nos capítulos 2 e 3 - o que justifica aqui e no Capítulo Zero a presença de nomenclaturas de outras linhas teóricas, as quais têm o intuito de selecionar fatores primordiais no estudo da ordenação.

Preferi apresentar os corpora já no início da tese para que o leitor tenha as informações necessárias para entender de maneira mais clara as motivações que me levaram a escolhê-los para esta pesquisa, bem como facilitar a compreensão das transcrições usadas (que mantêm marcações da língua oral) e que mantive nos exemplos, justamente com o intuito de preservar a naturalidade das interações. Para

\footnotetext{
4 Até esse momento, ainda pensávamos em ordenação de Palavras e não de constituintes. Com o decorrer das leituras e com a delimitação dos objetivos de pesquisa, preferi usar o termo constituintes e não Palavras, já que a unidade de análise selecionada é o Ato Discursivo. Como explicarei no capítulo 2, os Atos Discursivos podem corresponder a Palavras (tanto gramatical como lexical), Sintagmas, argumentos, modificadores, termos oracionais e extraoracionais, etc. Além disso, falar de ordem de Palavras poderia supor análises nos níveis sintagmáticos, como por exemplo as relações entre determinantes e seus núcleos (um artigo em relação a um substantivo, por exemplo), ou entre substantivo e adjetivo, além de muitas outras possibilidades, o que foge ao escopo deste trabalho.
} 
manter o maior grau possível de proximidade com o texto oral, fiz recortes dos áudios originais, que correspondem a cada um dos exemplos escritos e que podem ser acessados em uma pasta compartilhada em modo público do Google Drive ${ }^{5}$.

De maneira geral, esta tese está dividida em duas grandes partes: a primeira, composta pelos capítulos Zero, 1, 2 e 3, concentra as bases do referencial teórico escolhido e questões metodológicas. A segunda parte é composta pelos capítulos 4 , 5 e 6 e mescla teoria, descrição e resultados das análises dos dados que obtive dos corpora nas duas línguas. A seguir, descrevo um pouco mais detalhadamente sobre o que versará cada capítulo.

No capítulo 1, abordo algumas características da linguagem oral, explico os critérios de gravação e de transcrição usados no C-ORAL-ROM e no C-ORAL-BRASIL e apresento a metodologia usada nesta tese. Além disso, falo das minhas hipóteses iniciais e trago uma primeira versão dos objetivos da pesquisa.

No capítulo 2, apresento, de maneira mais geral, os principais pressupostos da linha teórica na qual se pauta esta pesquisa: a Gramática Discursivo-Funcional (GDF). Conto um pouco sobre o surgimento da teoria, bastante fundamentada no funcionalismo de Dik (1997), e de como se consolidou em 2008, com a publicação da obra Functional Discourse-Grammar. A typologically-based theory of language structure, dos autores e professores de Amsterdã: Kees Hengeveld e Lachlan Mackenzie. Na sequência, apresento o layout geral da GDF e explico brevemente todas as suas camadas e níveis.

O capítulo 3 é específico sobre os princípios de ordenação dos constituintes na GDF, com uma breve descrição e comparação de alguns aspectos entre o PB e o EP. Explico inicialmente o sistema de posições proposto pela teoria e, depois, os tipos de constituintes que podem ocupar cada uma dessas posições. Centro-me em descrever as três funções semânticas (Ator, Inativo e Locativo) e as duas funções sintáticas (Sujeito e Objeto) previstas na teoria.

O capítulo 4 está dedicado às três funções pragmáticas (Tópico, Foco e Contraste), além da categoria pragmática Ênfase. Esse aparato teórico me forneceu ferramentas para descrever quais são as estratégias linguísticas disponíveis para marcação dessas funções em ambas as línguas e variedades focalizadas nesta tese.

5 Disponível no seguinte endereço eletrônico:

https://drive.google.com/drive/folders/1cU8sTVChjMN uerPg1SgeqLbBo3qVK8r?usp=sharing 
Neste capítulo, é onde se centra a parte principal deste trabalho e onde apresento a maior parte das comparações entre as duas línguas.

No capítulo 5 apresento a parte teórica e as realizações de duas das funções retóricas que são interessantes do ponto de vista da ordenação: a Orientação e o Esclarecimento.

Finalmente, a ordenação das llocuções Interrogativas é descrita no capítulo 6 , onde abordo algumas questões relacionadas às Interrogativas Polares e às Interrogativas de Conteúdo, principalmente no que se refere ao tipo de respostas das primeiras e ao posicionamento do constituinte $Q$ nas segundas.

Por último, revisito a delimitação que fiz dos fatores de ordenação, para esta pesquisa, e retomo minhas hipóteses iniciais e meus objetivos, agora especificados. Normalmente, esses dados viriam já no início do trabalho, na Introdução ou em capítulos iniciais, porém, dada a especificidade do tema investigado, me pareceu mais coerente, primeiramente, apresentar ao leitor que porventura não conheça a linha teórica da Gramática Discursivo-Funcional os conceitos teóricos aos quais me refiro nos objetivos e nas hipóteses, para somente depois delimitá-los de maneira mais específica. Assim, quase que metalinguisticamente, esta tese, que versa sobre a ordenação, tem uma ordenação um pouco diferente da prevista normalmente. Por fim, traço algumas considerações finais, retomando as principais ideias dos capítulos anteriores e aponto possíveis caminhos de pesquisa que ainda podem ser explorados, tendo em vista a amplitude do tema tratado.

Sou consciente de que o recorte das variedades e variantes que fiz, tanto do português quanto do espanhol, é bastante específico e que outras variedades e variantes dessas línguas, bem como outros tipos de gêneros discursivos/textuais não contemplados nos corpora analisados para cada língua poderiam mostrar alguma variação em relação aos dados que apresento aqui. Esse recorte de variedades e variantes também aparece nas traduções que proponho nas duas línguas. Em muitos momentos, por exemplo, um pronome tú do espanhol poderia ser traduzido ao PB tanto por você como por tu. Assim, embora a linha teórica que adotei para análise, a GDF, tenha um forte caráter tipológico, não tenho a pretensão de generalizar as descrições feitas. Dou apenas um pequeno passo para que outras pesquisas ampliem as descrições aqui feitas contemplando outras variedades. 
PARTE I:

\section{SUPORTE TEÓRICO E METODOLOGIA}




\section{CAPÍTULO ZERO}

\section{PROLEGÔMENOS TEÓRICOS: DA ORDEM SINTÁTICA À ORDEM PRAGMÁTICA}

\subsection{Revisão teórica e bibliográfica sobre o espanhol}

Há diversos fatores que podem interferir na ordenação das Palavras em uma língua. Soriano (1993) nos fala dessa complexidade no espanhol:

Conseguir dar conta da distribuição dos elementos oracionais em uma língua de "ordem livre" implica aventurar-se na tarefa de desenredar um intrincado complexo de fatores e isso, além do mais, depois que já tivermos esses fatores localizados (SORIANO, 1993, p. 113). ${ }^{6}$

A autora já propunha a clara influência de fatores sintáticos, morfológicos, fonológicos e pragmáticos na expressão resultante no nível que ela chama de gramatical. Em outros termos, ela já considerava que os diferentes arranjos relativos à ordem das palavras não poderiam ser relegados à Estilística e que, pelo contrário, tinha fortes motivações não arbitrárias.

Fernández Soriano (1993) parte de uma visão tipológica de classificação das línguas, com base na teoria de Joseph H. Greenberg (1966) em sua obra Universals of Language. Dentro dessa vertente tipológica, busca-se identificar qual a ordem básica dos constituintes principais (Sujeito, Verbo e Objeto). A partir do estudo de 30 línguas de diferentes famílias linguísticas, Greenberg estabelece 24 tipos de línguas logicamente possíveis, comprovando a existência de 15 delas em seu corpus. Ele conclui que há seis possibilidades de ordenação, a saber: SVO, SOV, VSO, VOS, OSV e OVS, sendo que as mais recorrentes são as três primeiras. Em 1992, Dryer aumentou o corpus estudado para 625 línguas e concluiu que a ordenação SOV (língua de núcleo final) é a que mais ocorre, seguida da SVO (de núcleo medial).

\footnotetext{
${ }^{6}$ Tradução nossa do original: Tratar de dar cuenta de la distribución de los elementos oracionales en una lengua de "orden libre" implica aventurarse en la tarea de desenmarañar un intrincado complejo de factores y ello, además, una vez que los tengamos localizados.

${ }^{7}$ A partir deste momento, citaremos diversos autores, porém nem todos foram consultados diretamente, mas aparecem citados nas obras que tomamos como referência, sem apud para evitar muitas repetições. Por isso, nem todos os nomes que aparecerão integrarão nossas referências bibliográficas, apenas aqueles que foram consultados diretamente.
} 
É com base nessas classificações tipológicas, especialmente na de Greenberg (1966), que os estudos sobre ordenação de constituintes, de modo geral, têm recaído. Fernández Soriano (1993) seguindo, portanto, essa linha tipológica, concorda com outros autores ao classificar o espanhol como uma língua de ordem livre, do tipo SVO, e que essa liberdade se deve a Condições de Visibilidade:

[...] as orações bem formadas devem respeitar o que se conhece como Condição de Visibilidade, que especifica, dito de um modo muito esquemático, que o papel temático ou função semântica de 'agente', 'paciente', 'destinatário', etc., dos distintos elementos nominais deve ser reconhecível seja por meio de marcas formais (declinações, preposições, concordância, etc.), seja por adjacência estrita com o elemento ao qual é atribuída tal função (o verbo neste caso). (FERNÁNDEZ SORIANO, 1993, p. 118) ${ }^{8}$

Pelo fato de a língua espanhola dispor de marcas flexivas verbais, de pronomes átonos e de preposições, além de posicionamentos específicos para constituintes com funções semânticas (de acordo com seus papéis temáticos, segundo outras teorias que não a GDF), a autora constata que o critério da visibilidade está satisfeito em muitos aspectos, o que permite certa flexibilidade de ordenação dos constituintes, embora essa liberdade seja menor que em outras línguas como o latim, por exemplo. Zubizarreta (1992) e Yokota (2007) relacionam, por exemplo, a presença da preposição a no espanhol diante de certos objetos diretos com a possibilidade de anteposição ou posposição de certos constituintes. Nós retomaremos essa característica no capítulo 3. Como vemos, consideram-se elementos estruturais da língua para explicar fenômenos de ordenação. Como outros exemplos de ordenação motivada por fatores estruturais no espanhol, Fernández Soriano (1993, p. 121) cita as sentenças enunciativas, em que o Sujeito aparece posposto ao verbo como em (3):

\section{Ha llamado María.}

[Ligou Maria]

\footnotetext{
${ }^{8}$ Tradução nossa do original: [...] las oraciones bien formadas deben respetar lo que se conoce como Condición de Visibilidad, que especifica, dicho de modo muy esquemático, que el papel temático o función semántica de 'agente', 'paciente', 'destinatario', etc., de los distintos elementos nominales debe ser reconocible bien por medio de marcas formales (declinaciones, preposiciones, concordancia, etc.), bien por adyacencia estricta con el elemento que les asigna tal función (el verbo en este caso).
} 


\section{[(A) Maria ligou ${ }^{9}$}

Também constituem exemplos de ordenação gerada por uma restrição estrutural, segundo Fernández Soriano (1993, p. 122), as orações interrogativas parciais (chamadas na GDF de llocuções Interrogativas de Conteúdo), como em (4a), em que o Sujeito deve, obrigatoriamente, aparecer posposto ao verbo, já que (4b) é considerada agramatical, ao menos a partir dos estudos descritivos do espanhol consultados pela autora, que contemplam algumas de suas variedades apenas e nem sempre são feitos a partir da análise de corpora, variedades, variantes e registros variados. Vejamos os exemplos:

¿A quién ha visto Juan?

[Ø Quem viu Juan? ]

[Quem (o) Juan viu? ]

$$
\text { ¿¿A quién Juan ha visto? }
$$

$[\varnothing \text { Quem Juan viu? }]^{10}$

O mesmo ocorre com as orações exclamativas, como em (5), em que (5b) também é classificada pela autora como agramatical:

¡Qué bonito coche tiene Juan!

[Que bonito carro tem Juan!]

*iQué bonito coche Juan tiene!

[Que bonito carro Juan tem!] [Que carro bonito que o Juan tem!]

\footnotetext{
9 Todos os exemplos do espanhol que trazemos nesta tese, seja de outros autores ou de nosso corpus, terão ao menos uma tradução para o português, indicada entre colchetes sempre após cada exemplo em espanhol. No entanto, preferimos propor inicialmente sempre traduções do tipo palavra-por-palavra (conforme NEWMARK, 1988, e AUBERT, 1987, apud BARBOSA, 1990), ou seja, manter a ordenação dos constituintes usada na língua espanhola, mesmo que em algumas ocasiões isso gere construções pouco frequentes em PB, ou até mesmo agramaticais. Em alguns casos, essa tradução palavra-porpalavra muda completamente o sentido da expressão em espanhol e por isso, sempre que isso ocorrer, também apresentamos uma segunda tradução, funcionalmente equivalente ao texto original. Essa decisão já vai, inclusive, apontando, de maneira indireta, algumas semelhanças e diferenças de ordenação dessas duas línguas, que é o ponto central desta pesquisa.

10 Note-se que, neste caso, a ordenação tida como agramatical por Fernández Soriano é justamente a mais usual em PB.
} 
Fernández Soriano (1993) recorre ao modelo gerativista para explicar exemplos como (4) e (5), em que o Sujeito é deslocado de seu lugar canônico, inicial, pois essa posição passa a ser ocupada por um constituinte interrogativo ou exclamativo (embora reconheça que outros fatores podem intervir nesse processo), concordando com autores tais como Bosque (1980), C. Piera (1987) e Zubizarreta (1991), que tratam essas construções como casos de Rematização ou Focalização. A autora cita também outras características formais que são consideradas na ordenação do E, tais como: as propriedades do Sujeito (acompanhado ou não de um determinante, oracional ou não, por exemplo), o tipo de verbo (os chamados inacusativos e os psicológicos como gustar ou molestar, por exemplo, permitem facilmente Sujeitos pospostos, ou seja, a ordem VS), a complexidade dos constituintes (que, por isso, preferem ocupar posições finais nas sentenças), entre outras. Em sentenças com verbos transitivos, Fernández Soriano (1993, p. 121) observa que há várias possibilidades de ordenação no espanhol, como no seguinte exemplo (6), sendo o primeiro da série (a) considerado o menos marcado, por seguir a ordem SVO:

(6a) Juan ha comprado el periódico.

[Juan comprou o jornal].

(6b) Ha comprado Juan el periódico.

[Comprou Juan o jornal]

(6c) Ha comprado el periódico Juan.

[Comprou o jornal Juan].

A grande questão que se impõe, portanto, é: (6a), (6b) e (6c) são equivalentes? Fernández Soriano (1993) conclui que, apesar de não haver uma restrição formal para esses exemplos, essa liberdade de ordenação não é aleatória, já que cada sentença tem seguramente possibilidades diferentes de interpretações, baseadas em diferenças de informatividade, ou seja, de informações já conhecidas ou não pelos participantes do processo comunicativo. Assim, a autora observa que, muitas vezes, os objetivos discursivos dos Falantes entram em jogo com essas limitações estruturais: 
Aqui convivem (nem sempre em harmonia) a observação de que nas questões de ordem intervêm fatores relativos à distribuição da informação e que a posição de certos elementos está diretamente relacionada com fenômenos como a ênfase e o contraste, o foco e a pressuposição e outros que parecem sair do estritamente "gramatical" [...]. (FERNÁNDEZ SORIANO, 1993, p. 120) ${ }^{11}$

Conclui-se, portanto, a partir dos estudos de Fernández Soriano (1993), que há dois macrogrupos de fatores que podem influenciar a ordenação dos constituintes em E: os estruturais e os informacionais, e que, tradicionalmente, tem-se tomado a ordem SVO como base não marcada para descrever as possíveis alterações dessa ordem.

Em sua tese de doutorado, intitulada El orden de palabras en el español coloquial, [A ordem de palavras no espanhol coloquial] Padilla García (2001) também faz um exaustivo percurso histórico sobre como a questão da ordenação das Palavras em espanhol tinha sido abordada até então na gramática, retomando ideias de autores como Nebrija (1492), Salvá (1835), Hanssen (1913), Lenz (1916), Seco (1930), Gili Gaya (1961), Alcina y Blecua. (1975), Alarcos Llorach (1994) e Zubizarreta (1999). A partir de todo esse percurso, Padilla García (2001) conclui que o tema da estrutura da frase (nível sintagmático) está muito mais abordado nas gramáticas que a ordem dos elementos oracionais. E, de maneira geral, não se questiona o padrão linear SVO.

Padilla García (2001) também revisa as principais linhas teóricas linguísticas que abordaram a questão da ordenação nas línguas em geral, sintetizando as contribuições do estruturalismo, com autores como Sausurre (1916), e de autores da escola de Praga, como Mathesius (1961), segundo o qual já há uma preocupação funcional em relação à linguagem: Mathesius, segundo o pesquisador, já defendia que constituintes conhecidos pelo interlocutor (tema) ocupam uma posição inicial da Oração, enquanto constituintes que carregam a informação nova (rema), ocupam uma posição final. Parte-se, assim, do conhecido para chegar ao desconhecido.

Além disso, Padilla García (2001) retoma a tese de Bloomfield $(1933,1939)$ de que há uma conexão entre forma, sentido e função, e de Hockett (1958), cuja contribuição mais importante foram os conceitos de tópico e comentário (equivalentes

11 Tradução nossa do original: Aquí conviven (no siempre en armonía) la observación de que en las cuestiones del orden intervienen factores relativos a la distribución de la información y que la posición de ciertos elementos está directamente relacionada con fenómenos como el énfasis y el contraste, el foco y la presuposición y otros que parecen caer fuera de lo estrictamente "gramatical" [...]. 
aos de tema e rema). Segundo Hockett (1958), em línguas predicativas, como as indoeuropeias, ainda que não seja uma regra, frequentemente o tópico coincide com o Sujeito, enquanto o comentário, com o predicado. Na sequência, Padilla García (2001) sintetiza alguns pressupostos de um determinado momento do gerativismo, em que uma das grandes discussões é saber se a ordem pertence à estrutura profunda ou à superficial da linguagem; passa pelos estudos tipológicos e, finalmente, pelo funcionalismo, com autores como Dik (1978, 1989, 1997), Siewierska (1988), Martínez Caro (1999) e Salazar (2000). Padilla García (2001) sintetiza, ainda, as principais contribuições de autores que estudam a ordenação de uma perspectiva diacrônica, relacionando questões de ordem a mudanças linguísticas, e por autores de linha da aquisição da linguagem. Não detalharemos aqui essas linhas, mas, ao analisá-las, Padilla García (2001) conclui que o padrão SVO, que se tomava como ponto de partida nas gramáticas, é confirmado por essas novas perspectivas.

Por último, Padilla García (2001) resenha estudos monográficos sobre a ordenação em diversas línguas, dos quais queremos destacar os de Yokoyama (1986, apud PADILLA GARCÍA, 2001, p. 89), cujo objetivo principal é analisar como os fatores pragmáticos e gramaticais estão presentes de maneira conjugada na ordem de Palavras e na fonologia suprassegmental dos enunciados.

Outro estudo monográfico que merece destaque é o de Ocampo (1995), publicado em forma de artigo no livro de Downing e Noonan desse mesmo ano. $O$ objetivo principal de Ocampo é comprovar se o status informativo (dado/novo) de um constituinte, bem como a colocação do acento prosódico e a expressão de determinadas funções pragmáticas influenciam, de alguma maneira, na forma de ordenar as Palavras no espanhol. Sobre a língua espanhola, Ocampo chega à seguinte conclusão, segundo as palavras de Padilla García (2001, p. 100-101):

O mais interessante de seu artigo, no entanto, é resenhar que, na maior parte dos casos analisados, os enunciados seguem o que o autor chama ordem de palavras informativa. Ou seja, a informação que contém os enunciados segue uma ordem que vai do conhecido ao desconhecido (tema/rema) com $88 \%$ de casos sobre os exemplos totais de seu corpus; os 10\% restantes expressam funções pragmáticas (como contrário ao esperado, foco de contraste ou tópico) e a ordenação tema/rema muda para expressar essas funções pragmáticas. A ordem tema/rema constitui, assim, um universal linguístico que é confirmado, também, segundo Ocampo, pelos dados do espanhol. [...] O Livro de Downing e Noonan busca, de certo modo, explicitar uma pragmática universal da ordem de palavras 
relacionando-a com os princípios cognitivos que necessariamente também têm que ser universais, posto que existem determinadas necessidades pragmáticas (troca de informação, conhecimento da informação que se troca ou trocou anteriormente, etc.) que devem ser comuns a todas as línguas. ${ }^{12}$

Todos os artigos do livro de Downing e Noonan (1995), nos quais analisamse diversas línguas, acabam por demonstrar que as variações de ordem não são raras nem imprevisíveis, pois, apesar das diferenças entre as línguas (ou seja, apesar de cada uma usar determinados padrões de ordenação), todos os Falantes têm a necessidade de, por exemplo, introduzir um novo assunto no discurso, marcar desacordos, marcar contrastes, destacar elementos que julgam mais importantes no contexto comunicativo etc. Isso significa que, independentemente da língua, os Falantes têm capacidades cognitivas comuns e "[...] todas as variações possíveis da ordem de palavras efetuadas em uma determinada língua têm que estar de acordo com as restrições impostas por estas capacidades ${ }^{13 "}$ (PADILLA GARCÍA, 2001, p. 101).

Outros trabalhos sobre a ordenação das Palavras em espanhol citados por Padilla García (2001), como o de Contreras (1978), também trazem uma importante contribuição para a descrição da ordenação dos constituintes em espanhol, sob uma perspectiva gerativista, mas que considera, sobretudo, questões relativas à informatividade. O trabalho de Delbecque (1991) sobre o espanhol aborda o assunto a partir de uma perspectiva cognitiva, falando sempre em termos de tendências e não em termos absolutos, e destaca que a ordem de Palavras segue o princípio de iconicidade, ou seja:

\footnotetext{
12 Tradução nossa do original: Lo más interesante de su artículo, sin embargo, es reseñar que, en la mayor parte de los casos analizados, los enunciados siguen lo que el autor llama orden de palabras informativo. Es decir, la información que contienen los enunciados sigue un orden que va de lo conocido a lo desconocido (tema/rema) con un $88 \%$ de casos sobre los ejemplos totales de su corpus; el $10 \%$ restante expresa funciones pragmáticas (como contrario a lo esperado, foco de contraste o tópico) y la ordenación tema/rema cambia para expresar dichas funciones pragmáticas. El orden tema-rema constituye, pues, un universal lingüístico que es confirmado también, según Ocampo, por los datos del español. [...] El libro de Downing y Noonan busca, en cierto modo, hacer explícita una pragmática universal del orden de palabras relacionándola con principios cognitivos que necesariamente también tienen que ser universales, puesto que existen determinadas necesidades pragmáticas (intercambio de información, conocimiento de la información que se intercambia o ha intercambiado con anterioridad, etc.) que deben ser comunes a todas las lenguas.

13 Tradução nossa do original: [...] todas las variaciones posibles del orden de palabras efectuadas en una lengua dada tienen que estar de acuerdo con las restricciones impuestas por estas capacidades.
} 
[...] as variações sintáticas são produto de necessidades icônicas (naturalidade), próprias não de uma dimensão sintática, mas sim de um desenvolvimento discursivo mais amplo. Assim, podemos estabelecer uma relação entre a naturalidade icônica e a percepção do falante que dá lugar à representação verbal (esquerda-direita) e às variações possíveis da ordem. (PADILLA GARCíA, 2001, p. 155) ${ }^{14}$

Padilla García (2001) também fala sobre o que considera a grande inovação de Dik (1978, 1989, 1997), que é atribuir posições específicas para constituintes com funções pragmáticas, saindo da dicotomia que vinha dominando os estudos até então (tópico/comentário ou tema/rema ou dado/novo, seja qual for a nomenclatura que se use). De todo esse percurso teórico, Padilla García (2001) conclui que, apesar de os estudos sobre ordenação seguirem linhas e objetivos diferentes, e de poucos pesquisadores proporem uma generalização para suas propostas, todos coincidem em assinalar a confluência de diversos fatores que interferem na ordenação das diferentes línguas: fatores pragmáticos, informativos, semânticos, sintáticos etc. Nas palavras do pesquisador (2001, p. 177-178):

Depois de repassar todos os trabalhos, podemos estabelecer uma série de preocupações comuns que, de alguma forma, se repetem ao longo do tempo independente dos autores e das teorias: a) a problemática dos padrões básicos é um fator central, principalmente, do ponto de vista dos estudos tipológicos, b) quais são os componentes que formam a estrutura informativa e como essa estrutura influencia na ordem final dos constituintes da oração, c) existem posições com um determinado valor pragmático, informativo etc., d) os enunciados não são o resultado de um fator único e concreto, mas da união de diversos fatores que atuam de maneira conjunta e, em ocasiões, se contradizem. ${ }^{15}$

Após analisar vários fatores de ordenação das Palavras em seis entrevistas orais, Padilla García (2001) conclui que realmente há um padrão de ordenação para

\footnotetext{
14 Tradução nossa do original: [...] las variaciones sintácticas son producto de necesidades icónicas (naturalidad), propias no de lo sintáctico sino de un desarrollo discursivo más amplio. Así, podemos establecer una relación entre la naturalidad icónica y la percepción del hablante que da lugar a la representación verbal (izquierda-derecha) y a las variaciones posibles del orden.

15 Tradução nossa do original: Después de repasar todos los trabajos, podemos establecer una serie de preocupaciones comunes que, de alguna forma, se repiten a lo largo del tiempo independientemente de los autores y las teorías: a) la problemática de los patrones básicos es un factor clave, principalmente, desde los estudios tipológicos, b) cuáles son los componentes que forman la estructura informativa y cómo influye dicha estructura en el orden final de los constituyentes de la oración, c) existen posiciones con un determinado valor pragmático, informativo, etc., d) los enunciados no son el resultado de un factor único y concreto, sino de la conjunción de factores diversos que actúan de manera conjunta $y$, en ocasiones, se contradicen.
} 
o espanhol, que é (S)VO16 (que ele chama de ordem sintática), e que toda ordem diferente disso tem motivações pragmáticas, ou seja, são, segundo ele, ordens pragmáticas.

A intenção, nesta seção de nosso trabalho, foi demonstrar que, após analisar todas as categorias já discutidas nos estudos linguísticos, sob diferentes olhares teóricos e com nomenclaturas próprias (e que muitas vezes podem ser usadas como sinônimos, inclusive), os estudos sobre ordenação culminam, em maior ou menor medida, em uma explicação pragmática para os diferentes arranjos de constituintes. O mesmo acontece com os estudos de ordenação das Palavras em português, como veremos a seguir.

\subsection{Revisão teórica e bibliográfica sobre o português}

Tradicionalmente, e também com forte influência nos estudos tipológicos, assim como o espanhol, o português tem sido classificado como uma língua do tipo SVO, alegando-se ser essa sua ordem não marcada, com base na frequência de uso. Para Bagno (2012), por exemplo, as ordens SOV e SVO correspondem a $75 \%$ das línguas do mundo, com base nas sentenças mais frequentes e mais "neutras". Tratase de ordens mais naturais, por refletirem a ordem mesma do que está sendo enunciado, devido a mecanismos cognitivos e à hipótese da iconicidade ${ }^{17}$.

Castilho (2010) também assume que a ordem básica não marcada do PB é SVO, podendo os constituintes se movimentar criando ordens marcadas como OSV, SOV e VSO. Muitos outros autores defendem essa mesma ideia para o PB. Pezatti (2012), por exemplo, cita Pádua e Canaes (1960), Lopes (1981), Braga (1986), Pontes (1987), Decat (1989), Berlinck (1989) etc.

Para retomar de maneira sintetizada os principais estudos sobre ordenação dos constituintes em português, e mais especificamente no $\mathrm{PB}$, nos valeremos principalmente dos estudos de Pezatti (1992, 1994, 2014) e Marques (2012).

\footnotetext{
${ }^{16}$ Outros estudos, como os de González (1994), Groppi (2006) e Freire Santos (2013) já demonstraram que há uma forte tendência de ocultamento dos constituintes com função sintática de Sujeito no espanhol (Sujeito nulo), devido à manutenção e diversidade das desinências verbais nessa língua e que o uso de um Sujeito explícito na maioria das vezes tem uma função pragmática Contrastiva (diferente do PB, em que a perda das desinências verbais muitas vezes leva o Falante a usar Sujeitos explícitos para evitar ambiguidades). Voltaremos a essa questão no capítulo 3.

${ }^{17} \mathrm{O}$ princípio da iconicidade será explicado mais adiante.
} 
A ordem SVO toma como central o verbo de dois argumentos, caso em que a função sintática realmente é definida pela posição. Porém, em pesquisas na qual analisa dados extraídos do corpus oral NURC ${ }^{18}$, Pezatti $(1992,1994)$ verifica que apenas $32,4 \%$ das estruturas oracionais são formadas por verbos de dois argumentos, o que desmistifica o que se vinha propondo até então de que o PB seria uma língua SVO (já que SVO implicaria necessariamente um verbo de dois argumentos). A pesquisadora constatou que quase $70 \%$ das estruturas correspondiam a verbos de apenas um argumento e separou-as em dois grupos: no primeiro estão as estruturas com verbos intransitivos de estado, ação e processo (denominados verbos não existenciais), cujo argumento aparece em posição anterior ao verbo; no segundo grupo estão as estruturas com verbos que denotam existência ou emergência de uma entidade (verbos existenciais) como ser, ter, haver, acontecer, ocorrer, aparecer, surgir e faltar. Os argumentos desse segundo grupo se posicionam depois do verbo, acarretando a ordem VS que, nas pesquisas de Pezatti (1992, 1994), constituíram $94,7 \%$ dos dados, evidenciando que a chamada ordem invertida ou marcada na verdade é natural e altamente frequente na língua. Em conclusão, Pezatti (1994) propõe duas ordens básicas no português: SVO e VS.

No entanto, as estruturas VS, em que o Sujeito ocupa a mesma posição do Objeto, apontam para que o PB também seja uma língua do padrão ergativo/absolutivo, ou seja, aquela em que a oposição fundamental entre duas funções sintáticas não se dá entre a diferenciação de Sujeito e Objeto Direto (OD), mas sim entre o Sujeito de um verbo transitivo e o Objeto Direto desse verbo; além disso, a função do OD confunde-se com a do Sujeito de um verbo intransitivo. É o que acontece, por exemplo, na sentença (7):

Ocorreu um acidente.

A partir dessas constatações, Pezatti (2014, p. 28) diz que:

${ }^{18}$ A sigla NURC refere-se ao Projeto de Estudo da Norma Urbana Linguística Culta. Esse projeto começou a ser desenvolvido no Brasil em 1969, inspirado na proposta de Juan Lope Blanch, de um grande projeto coletivo que registrasse a norma culta do espanhol falado. Em português, o projeto NURC coletou dados de cinco capitais brasileiras: Recife, Salvador, São Paulo, Rio de Janeiro e Porto Alegre. As gravações são constituídas $40 \%$ de diálogos entre dois informantes e $40 \%$ de diálogos entre o informante e o documentador. Os outros $20 \%$ são de gravações secretas de um diálogo espontâneo e de elocuções formais. 
[...] nas línguas nominativo-acusativas, pode-se usar o termo sujeito para o grupo formado por Si e St, já nas ergativo-absolutivas, o termo deveria referir-se ao grupo $\mathrm{S}$ e $\mathrm{O}$, ou seja, a $\mathrm{O}$ mais que St numa sentença transitiva. ${ }^{19}$.

Isso marca uma categoria híbrida do Sujeito no PB, que muitas vezes pode coincidir com a função pragmática de Tópico. A autora conclui, portanto, que talvez seja mais prudente e coerente pensar em uma estrutura Tópico-Comentário, e não Sujeito-Predicado. Essa proposta nos parece bastante pertinente e podemos dizer que vai ao encontro das conclusões de Marques (2012), que explicaremos a seguir, e também da perspectiva teórica que adotamos nesta pesquisa, de considerar que a sintaxe está subjugada à pragmática.

Em sua tese de doutorado, Marques (2012) faz um estudo diacrônico da ordenação do Sujeito em relação ao verbo, em português, descrevendo sua posição em textos dos séculos XIV ao XX. A pesquisadora leva em consideração tipos de verbos (tanto do ponto de vista semântico - ao analisar os verbos dicendi20, por exemplo, como do ponto de vista argumental - como os transitivos diretos e/ou indiretos, intransitivos e copulativos), planos discursivos (figura/fundo) e estatuto informacional veiculado pelo Sujeito (dado, novo, etc.). Ela constata que, em todo o período analisado, Sujeitos informativamente novos tendiam a aparecer pospostos ao verbo, enquanto Sujeitos evocados tendiam a ocupar uma posição pré-verbal. Segundo ela "Isso comprova a hipótese arrolada inicialmente de que o Sujeito com informação dada constitui o tópico da estrutura tópico-comentário, estando à direita do verbo os elementos com maior grau de novidade" (MARQUES, 2012, p. 102).

A pesquisadora ainda diz que "No caso das cláusulas intransitivas, embora tenhamos verificado um alto número de sujeitos evocados em posição pós-verbal, a posposição manteve-se em todos os séculos extremamente relacionada à novidade do referente sujeito" (MARQUES, 2012, p. 115). A pesquisa de Marques corroborou, assim, a ideia antes defendida por Pontes (1987), Berlinck (1989, 1995), Coelho (2000) e Spano $(2002,2008)$ sobre a predominância de posposição do Sujeito com verbos intransitivos, principalmente os apresentativos e existenciais. Além disso, confirmou-se que a ordem VS não está associada apenas à característica sintático-

\footnotetext{
${ }^{19} \mathrm{Si}=$ Sujeito de verbo intransitivo; $\mathrm{St}=$ Sujeito de verbo transitivo.

${ }^{20}$ Verbos dicendi são verbos de dizer, ou seja, verbos usados para introduzir, de forma direta ou indireta, as palavras de alguém, tais como falar, dizer, ordenar, mandar e contar.
} 
semântica do verbo, mas também a traços do SN, tais como definitude e estatuto informacional: SNs [-definidos] e novos apresentam uma maior tendência de parecerem pospostos, ao contrário dos SNs [+definidos] e conhecidos.

A pesquisadora verificou, ainda, que:

[...] um número considerável de dados em que a ocorrência de sujeitos em posição pós-verbal em cláusulas com elemento adverbial na primeira posição deve-se não ao posicionamento do adverbial na fronteira esquerda, mas ao papel temático atribuído a esses elementos - adverbial [+Tópico] e sujeito [+Foco], veiculando informação nova. (MARQUES; 2012, p. 134).

Ou seja, o que de fato determina a ordenação nesses tipos de construções não é a presença de um advérbio (não tem motivação/restrição estrutural). A ordenação do Sujeito é definida pelo valor discursivo que o constituinte com função sintática de Sujeito apresenta, ou seja, depende do seu grau de informatividade.

No que tange às cláusulas intransitivas, a ordem VS, tida como não marcada no português arcaico por ser mais frequente que a SV, passa a ter sua produtividade reduzida ao longo do tempo, principalmente a partir do século XVIII, chegando a ficar restrita a contextos específicos no português atual. Segundo a autora (2012, p. 142):

Observamos que os contextos de ocorrência de VS em todos os séculos são preferencialmente os que apresentam verbos de apresentação e são esses que se mantêm na língua, tendo, devido à sua frequência, uma forte representação na mente dos falantes.

A pesquisadora argumenta que as Orações com verbos dicendi, especificamente, apresentam estruturas que são cristalizações de estratégias discursivas, sedimentadas em função de sua frequência de uso, estando, portanto, relacionadas à tradição discursiva. "Tais construções refletem uma estratégia de distanciamento do Falante/escritor em relação ao que está sendo citado, ponto em que reside o foco sentencial” (MARQUES, 2012, p. 142).

A constatação de Marques (2012), ao final de todo o trajeto por ela feito, é que a ordenação do Sujeito não está relacionada apenas a fatores estruturais e que, pelo contrário, é fortemente influenciada por fatores discursivos e pragmáticos, principalmente pelo estatuto informacional dos constituintes. Segundo a pesquisadora: 
Diante desses resultados, podemos concluir que o fenômeno da ordenação do sujeito em relação ao item verbal mostrou-se essencialmente funcional em todos os séculos. Inclusive em casos em que aparentemente se verificava influência de um fator estrutural, observamos que atuavam aspectos discursivo-pragmáticos. (MARQUES, 2012, p. 145).

Nesta seção do trabalho, não detalhamos mais o percurso dos estudos de Marques (2012), pois muitas de suas referências teóricas são as mesmas que já citamos acima, isto é, a autora se baseia nos mesmos trabalhos citados por Fernández Soriano (1993) e por Padilla García (2001), justamente por versarem sobre a ordenação das Palavras em diversas línguas. Assim, quisemos trazer aqui os estudos específicos sobre o português, para mostrar, que, ao final, chega-se à mesma conclusão a que se chegou analisando os trabalhos sobre o espanhol: apesar da existência de diversos fatores que influenciam a ordenação e que interagem entre si, a questão pragmática parece ter um destaque bastante proeminente.

\subsection{Sintetizando}

As conclusões dos estudos mencionados nos itens anteriores, tanto para o espanhol como para o português, em especial o PB, servem como pressupostos para nossa pesquisa: tomamos as conclusões desses autores, portanto, como nosso ponto de partida. Em outras palavras, partiremos do pressuposto de que a ordenação dos constituintes, nas duas línguas com as quais trabalhamos, inclusive nas variedades aqui contempladas, é o resultado de intenções comunicativas dos Falantes. Essas intenções estão no âmbito da cognição, ou, segundo a teoria que adotaremos, estão no Componente Conceitual, e são universais, aplicando-se a todas as línguas, como vimos em Padilla García (2001): todos os Falantes, independentemente da língua, têm necessidades comunicativas de informar, de contrastar, de enfatizar elementos, etc. A maneira de fazê-lo, no entanto, pode variar de língua para língua. E é exatamente aqui que começa nosso trabalho: na comparação de como se expressam essas funções pragmáticas e também retóricas, como mostraremos mais adiante, no PB e no EP, em especial nas variedades e no registro oral presentes nos corpora escolhidos para nossas análises, os quais, mesmo não nos permitindo generalizações absolutas, certamente são indiciais de um determinado tipo de tendência. Esses indícios poderão, posteriormente, ser usados para novas pesquisas no sentido de ver até onde 
essas tendências se estendem e se mantêm (ou não). Temos, portanto, aqui, a primeira grande delimitação/o recorte do nosso objetivo inicial mais abrangente.

No capítulo a seguir, apresentamos os projetos do C-ORAL-ROM e do CORAL-BRASIL, de onde extraímos nossos corpora, bem como a metodologia usada e uma primeira apresentação dos nossos objetivos. 


\section{CAPÍTULO 1 \\ OS PROJETOS C-ORAL-ROM E C-ORAL-BRASIL}

Neste capítulo, apresentamos os projetos C-ORAL-ROM e C-ORAL-BRASIL, de onde extraímos nossos subcorpora, ou seja, as amostras deles retiradas para nossas análises, descrevendo critérios de gravação, de transcrição, o recurso de alinhamento, os tipos de participantes, entre outros fatores. Além disso, apresentamos nossos subcorpora e a metodologia que adotamos, tanto para a seleção dos arquivos, quanto para as análises. Além disso, como comentamos na Introdução, apresentamos uma primeira versão dos objetivos de pesquisa, e falamos aqui de uma primeira versão porque preferimos mostrá-los, neste capítulo, apenas em linhas gerais, fundamentalmente baseando-nos nas perguntas a serem respondidas, preferindo explicar questões teóricas e definições que adotamos, antes de apresentar a versão completa dos nossos objetivos, final do trabalho.

Como explicamos na Introdução, optamos por apresentar esses projetos e nossos subcorpora já no início do nosso trabalho por dois motivos principais: (i) aportar dados para a melhor compreensão dos exemplos (das ocorrências) que citamos nos capítulos seguintes, já que preferimos manter a transcrição com as marcas prosódicas. Por essa razão, nos pareceu importante, também, trazer aqui alguns aspectos da linguagem oral; e (ii) justificar a escolha desses projetos para constituírem nossos corpora, haja vista nossa perspectiva pragmática.

\subsection{O Projeto C-ORAL-ROM}

Conforme Biber (1988), Blanche-Banveniste (1990), Cresti (2000), entre outros (todos apud CRESTI \& MONEGLIA, 2005), até a década de 90, a maioria dos estudos linguísticos baseava-se em corpora de língua escrita, com pressuposição de um modelo ideal de língua. Os estudos de linguagem falada espontânea têm se consolidado apenas recentemente. Nesse contexto de consolidação, mais precisamente em 1999, um grupo de pesquisadores de várias universidades europeias se dedicou a elaborar um corpus de língua falada com arquivos de áudio, na tentativa de minimizar a lacuna que existia de materiais desse tipo, principalmente 
nas línguas românicas (pois em inglês essa carência era comparativamente menor que em outras línguas). Surgiu, então, o projeto C-ORAL-ROM - Integrated Reference Corpora for Spoken Romance Languages, sob a coordenação de Emanuela Cresti, Massimo Moneglia, Claire Blanche-Benveniste, Fernanda Bacelar, Phillipe Martin, Francisco Marcos Marín e Carlota Nicolás, grupo esse apoiado e coordenado pela Universidade de Florença (Itália), com objetivo de prover um conjunto de amostras de linguagem espontânea das línguas francesa, italiana, portuguesa europeia e espanhola peninsular.

Por se tratar de um corpus de língua oral espontâneo, julgamos conveniente trazer aqui algumas características gerais dessa modalidade. De acordo com Moneglia (2005, p. 4), há vários tipos de linguagem espontânea, que variam de acordo com os seguintes parâmetros:

(a) uma variedade de estruturas de acordo com o evento comunicativo (monólogo, diálogo, conversa entre vários participantes, etc.); (b) o canal de comunicação utilizado; (c) o contexto social, ou seja, o domínio da sociedade em que os eventos de fala ocorrem (âmbito familiar, privado, público); (d) condições de programação (desde totalmente não planejado a parcialmente ou totalmente planejado); (e) variedade de registros e do estilo (variação diafásica); (f) fatores sociolinguísticos, tais como idade dos falantes, sexo, nível educacional, profissão, etc.; (g) origem geográfica dos falantes (variação diatópica); (h) o objetivo do evento comunicativo; (i) o tópico (assunto) do evento comunicativo. (MONEGLIA, 2005, p. 5) ${ }^{21}$.

Sendo assim, vemos que os eventos de fala podem variar de acordo com fatores não linguísticos. Por isso também, um banco de dados de língua falada deve considerar e contemplar toda essa variedade, além de usar a tecnologia adequada para garantir uma boa qualidade acústica das gravações e ter o menor controle possível do pesquisador, a fim de manter a naturalidade da comunicação entre os participantes.

${ }^{21}$ Tradução nossa do original: May types of spontaneous speech exist, varying along the following parameters: (a) a variety of possible structures of the communication event (monologue, dialogue, conversation between many participants, etc.); (b) the channel of communication of the speech event; (c) the sociological context, that is, the domain of society in which the speech event takes place (family life, private life, public life); (d) programming conditions (totally unscripted vs. scripted or partially scripted performances); (e) a variety of possible language registers and genres (diaphasic variation); (f) sociolinguistic factors, such as sex, age, education, occupation of the speakers (diatrastic variation); (g) the geographical origin of speakers (diatopical variation); (h) the task of the speech event; (i) the topic of the speech event. 
Nossa escolha pelo C-ORAL como corpus desta pesquisa se justifica, entre outros motivos que se explicarão a seguir, pelo fato de seus idealizadores e executores respeitarem essas peculiaridades da língua falada e terem constituído um banco de dados que leva em consideração os seguintes parâmetros:

(i) as sessões de gravações são classificadas em monólogos, diálogos e conversas, o que considera, portanto, o item (a) elencado por Moneglia (2005), como vimos acima, ou seja, considera uma diversidade de estruturas de acordo com o evento comunicativo;

(ii) o canal, contemplando o item (b) supracitado, já que se distinguem as interações face a face das gravações telefônicas e das emitidas pela mídia; (iii) o contexto social das interações, contemplando o item (c) de Moneglia, já que as gravações do corpus estão divididas entre familiares/privadas versus públicas, com a preocupação em diversificar os ambientes das gravações (como casas dos participantes, universidade, comércios, clínicas, etc.);

(iv) variação diafásica, contemplando o item (e) acima, por haver uma diferenciação entre gravações em que se usa um registro mais formal da língua de outros mais informais, sendo cerca de $50 \%$ para cada. Essa variação de registro está vinculada ao ambiente em que ocorre a gravação, ao grau de familiaridade entre os participantes, entre outros fatores;

(v) parâmetros do Falante, contemplando o item (f) de Moneglia, já que as principais características sociolinguísticas dos Falantes são registradas nas fichas de metadados, tais como idade, sexo, nível educacional, profissão e origem geográfica. Aqui, faz-se importante observar que a variação diatópica não é representada no C-ORAL, pois esse corpus traz unicamente as variedades linguísticas de Portugal continental, do centro da Espanha (região de Castela) (a que usamos para nossas observações sobre o espanhol), do sul da França e de parte ocidental da Toscana, considerando que, segundo seus idealizadores, um corpus multilíngue de reduzido tamanho, como este, deve estabelecer limitações de variedades geográficas;

(vi) o assunto do evento comunicativo: o item (i) elencado por Moneglia (2005), ou seja, o assunto do evento comunicativo, também é uma preocupação dos coordenadores do projeto, que têm o cuidado inclusive de 
incluir, na ficha dos metadados, um título para os arquivos e um resumo, ambos relacionados ao assunto da gravação.

Além de todas essas características, mantidas nas amostras das quatro línguas do projeto, o C-ORAL-ROM também apresenta, na ficha de metadados, a quantidade de Palavras de cada gravação, a fim de definir a dimensão das amostras, visando a maior equidade possível entre as quatro línguas, uma vez que o objetivo foi a construção de um corpus comparável.

Concluímos, portanto, que o C-ORAL-ROM consegue preservar todos os requisitos primordiais na construção de um banco de dados confiável de língua falada, embora haja a necessária limitação das variedades diatópicas, que poderão ser complementadas com futuros projetos.

Já apresentados os parâmetros seguidos pela equipe do C-ORAL-ROM, podemos então descrever o corpus completo do projeto. Ele está constituído por um total de 772 textos orais, o que equivale a aproximadamente 300.000 Palavras para cada um dos quatro idiomas e totaliza 121:43:07 horas de gravações, com participação de 1.427 Falantes. Cada arquivo de áudio do projeto vem acompanhado por esses três componentes: (a) metadados, contendo informações sobre os Falantes, contexto da gravação, qualidade acústica e o tema de cada sessão; (b) transcrição ortográfica, com marcação de pausas terminais e não terminais; e (c) sincronização do texto escrito e do áudio (baseada nas transcrições dos áudios). Mais adiante, falaremos um pouco mais sobre cada um desses três componentes.

A fim de simplificar as fichas de metadados disponíveis no DVD do projeto, criamos fichas adaptadas às necessidades de nossa pesquisa, com os dados relevantes para nós. Além disso, traduzimos as informações do inglês, deixando todas as nossas fichas em português, como no exemplo abaixo:

\section{Arquivo: efamdl01}

Participantes e situação: uma professora e uma aposentada conversando sobre atividades para distração (cursos de música e de computação) enquanto tomam café. Lugar: na casa de uma delas Duração e número de Palavras: 6'31" - 1574 
Como se vê, em nossa ficha adaptada, constam os seguintes dados: nome do arquivo, seguindo a mesma convenção do C-ORAL; sobre os participantes, informamos apenas suas profissões e mesclamos esses dados com uma pequena descrição da situação. Em seguida contextualizamos onde ocorre a interação e o tamanho do arquivo, em tempo e número de Palavras. Não informamos as cidades de origem dos Falantes, pois, como já explicamos anteriormente, selecionamos apenas áudios de madrilenhos, no caso do corpus em espanhol, e mineiros, no caso do corpus em PB, como se verá mais adiante. As idades e níveis de escolaridade também não serão tratados como fatores que poderiam influenciar na ordenação dos constituintes oracionais, uma vez que se excluem do C-ORAL áudios de Falantes menores de 18 anos de idade (não há, portanto, dados de linguagem infantil, que provavelmente deveriam ser analisados de outra perspectiva). Quanto aos níveis de escolaridade, tentamos selecionar a maior diversidade, indo de pessoas com pouco ou nenhum estudo formal a pós-graduados.

No C-ORAL, a equipe de transcritores é formada por doutores e estudantes de doutorado e o seguinte protocolo foi adotado: (a) marcação das pausas prosódicas simultaneamente com a transcrição pelo primeiro transcritor; (b) revisão das marcações por outro transcritor; (c) revisão por um terceiro transcritor, já utilizando o alinhamento entre texto escrito e áudio. Ademais, as anotações de pausas também foram revisadas por transcritores de uma instituição externa. A seguir reproduzimos a tabela de símbolos e convenções para as marcações das pausas prosódicas usadas em todo o projeto: 


\begin{tabular}{|c|l|}
\hline$/ /$ & Pausa prosódica final. \\
\hline$?$ & Marcação de pausa final em enunciados interrogativos. \\
\hline$\ldots$ & $\begin{array}{l}\text { Marcação final quando o enunciado é deixado propositadamente } \\
\text { suspenso pelo Falante. }\end{array}$ \\
\hline+ & $\begin{array}{l}\text { Marcação final para o enunciado que é interrompido pelo } \\
\text { interlocutor ou por eventos do ambiente. }\end{array}$ \\
\hline$/$ & Pausa prosódica não final. \\
\hline$[/]$ & Pausa não final causada por um falso início (retracting). \\
\hline$[/ /]$ & $\begin{array}{l}\text { Pausa não final causada por um falso início (retracting) de tal modo } \\
\text { que apenas uma parte do material linguístico é repetido. }\end{array}$ \\
\hline$[/ / /]$ & $\begin{array}{l}\text { Pausa não final causada por um falso início (retracting) de tal modo } \\
\text { que o material linguístico não é repetido. }\end{array}$ \\
\hline
\end{tabular}

Figura 2 - Convenções das etiquetagens prosódicas nas transcrições no C-ORAL-ROM

(MONEGLIA, 2005, p. 27)

Vale lembrar que, com exceção dos símbolos $/ l+$ e l, todos os demais são opcionais.

As interrupções (+) podem ser causadas por uma mudança da programação linguística do Falante ou por uma intromissão do interlocutor ou de outras pessoas, bem como por outros eventos do ambiente (alguém que toca a campainha, o telefone que toca, alguém que chega, etc.). Elas podem ser acompanhadas por fragmentação de Palavras, embora o mais comum seja a ausência da fragmentação.

Para explicar o fenômeno do retracting [/], que aparece na tabela acima, trazemos as palavras de Moneglia (2005, p. 27):

O Retracting (ou falso início) é o fenômeno de fragmentação mais frequente na fala espontânea. O falante hesita enquanto tenta encontrar a melhor maneira de se expressar e pausa sua fala antes de escolher entre duas alternativas. Esse fenômeno geralmente é facilmente distinguível das interrupções ou mudanças de programação [...] que não demonstram hesitação do falante e, ao contrário das interrupções, os retracting são quase sempre acompanhados de repetição (completa ou parcial) do material linguístico, e claramente causa a perda do valor informativo do material retraído, que é abandonado pelo falante em favor da alternativa escolhida. ${ }^{22}$

\footnotetext{
22 Tradução nossa do original: Retracting (or false start) is the most frequent fragmentation phenomenon in spontaneous speech. The speaker hesitates while trying to find the best way to express himself and retracts his speech before choosing between two alternatives. This phenomenon is, generally, clearly distinguish-able from interruptions or changes in programming [...] which do not feature speaker's
} 
Já esclarecidos os critérios de segmentação dos áudios, vejamos agora os principais parâmetros para as transcrições ortográficas. O formato das transcrições é o padrão (standard) (CHAT format, MACWHINNEY, 1994, apud MONEGLIA, 2005), com a representação das características mais relevantes dos diálogos, ou seja, a marcação de turnos dos Falantes, as principais ocorrências não linguísticas e paralinguísticas, as pausas prosódicas e a segmentação do discurso em eventos de fala. As palavras são transcritas de acordo com as convenções ortográficas de cada língua, e cada turno de um Falante é expresso pelo símbolo $\left(^{*}\right)$ imediatamente seguido das três letras iniciais de seu nome. Essa marcação de turno, porém, nem sempre é clara, pois pode haver, por exemplo, turnos concomitantes. Esse fenômeno recebe o nome de Overlapping (Sobreposição) e o fragmento de texto sobreposto é colocado entre os símbolos < > No C-ORAL essa marcação só ocorre quando a sobreposição acontece entre pelo menos duas Palavras em dois diferentes turnos, o que significa que sílabas sobrepostas não são marcadas. Quando não se consegue identificar o Falante, usa-se a marcação XYZ para identificar um turno misto.

Sistematizando esses símbolos em um quadro e acrescentando os de outros fenômenos da língua falada, temos o seguinte:

\begin{tabular}{|c|l|}
\hline$<>$ & Marcação do começo e do fim do trecho sobreposto. \\
\hline${ }^{*} \mathrm{XYZ}$ & Turno sobreposto emitido por Falantes não identificados. \\
\hline$\&$ & Fragmento de fala. \\
\hline hhh & Elementos paralinguísticos ou não linguísticos. \\
\hline xxx & Palavra incompreensível. \\
\hline yyy & Palavra não transcrita. \\
\hline yyyy & Sinal de áudio não transcrito. \\
\hline$\#$ & Pausa no fluxo de fala. \\
\hline
\end{tabular}

Figura 3 - Convenções das etiquetagens de turnos e elementos paralinguísticos

(MONEGLIA, 2005, p. 29)

As Palavras não transcritas (yyy) devem-se ou à preservação da face do Falante e de outras pessoas (omissão do nome ou de alguma referência que o

hesitations. Contrary to interruptions, retracting is almost always accompanied by the repetition (complete or partial) of the linguistic material, and clearly causes a loss of the informational value of the retracted material, which is abandoned by the speaker in favor of the chose alternative. 
identifique) ou à omissão de termos pejorativos e ofensivos. Além dos símbolos já elencados, também é possível que apareçam símbolos referentes ao contexto em que as conversas ocorrem, como alguma ação praticada pelo Falante, algum gesto, descrição do cenário, etc. Não os detalharemos aqui por julgarmos pouco relevante para nossa análise. Abaixo, trazemos como exemplo um fragmento de texto transcrito.

*LOL: hhh la <gente> //\$

\%act: (1) laugh

*PIL: $[<]<0$ sea> / que tú me encuentras bien / Lola //\$

*LOL: yo te encuentro mucho mejor / ahora //\$

*PIL: me trago [/] me pego [/] me pego unos solos / también aquí de aburrimiento que \&t $[/]$ \&t $[/]$ te $[/]$ tienes que buscarte ...\$

*LOL: yo estoy todo <el día haciendo $>\$$

$\%$ alt: (3) to

${ }^{*} \mathrm{PIL}:<\mathrm{xxx}$ también / eh> ?\$

*LOL: / cosas //\$

*PIL: eso sí // $\$$ te tienes que buscar formas / porque si no / puedes entrar en picado / si no <sales $>/ / \$$

*LOL: [<] <mira> / llevo tres días / que me [///] digo bueno me voy a acostar //\$ entonces paso por la habitación del teclado y digo / \$ ¡hum! / jay! esa

partitura debería / mirármela un momento /

\%alt: (12) entoes

*PIL: hhh $/ / \$$

\%act: (1) laugh

*LOL: / y me pongo en el / teclado //\$

*PIL: hija / te veo <muy $>+\$$

*LOL: $[<]<$ tres $>$ horas $/ / \$$ las tres de la mañana $/ / \$$

*PIL: / muy <inspirada $>/ / \$$

*LOL: $[<]<$ y yo> / aquí //\$ hhh haciendo el idiota / que sigo / chinchín chichín / tecla para arriba / tecla para abajo //\$

\%alt: (11) and (14) pa

*PIL: pero / eso es una buena señal //\$ <porque $x x x>/ / \$$

*LOL: $[<]<$ malísima / porque> a la / mañana siguiente / estoy que me <muero> // $\$$

Figura 4 - Exemplo de transcrição ortográfica no C-ORAL-ROM

Já abordamos até aqui dois dos parâmetros seguidos no C-ORAL: os metadados e a transcrição ortográfica. Falta-nos, portanto, falar sobre o terceiro parâmetro: o alinhamento entre texto escrito e áudio. Esse recurso é conseguido por meio do WinPitch Corpus, um programa operado em XML que acompanha o DVD do livro. Com ele, é possível alinhar texto (extensões *txt ou *rtf) e fala (extensões *wav ou * mp3). Cada unidade de texto (sendo sílaba, palavra, frase ou sentença) recebe um índice temporal conforme a posição do tempo de seu equivalente no arquivo de 
som. Uma vez feito isso, o operador pode selecionar uma unidade de texto alinhado e escutar seu segmento de fala correspondente. A análise acústica, com a curva melódica e o espectrograma, podem ser mostrados simultaneamente. Apesar de não fazermos uma análise acústica das gravações, usamos esse recurso para facilitar a interpretação dos diálogos e conversas. Exemplificamos a seguir a tela de um alinhamento: 


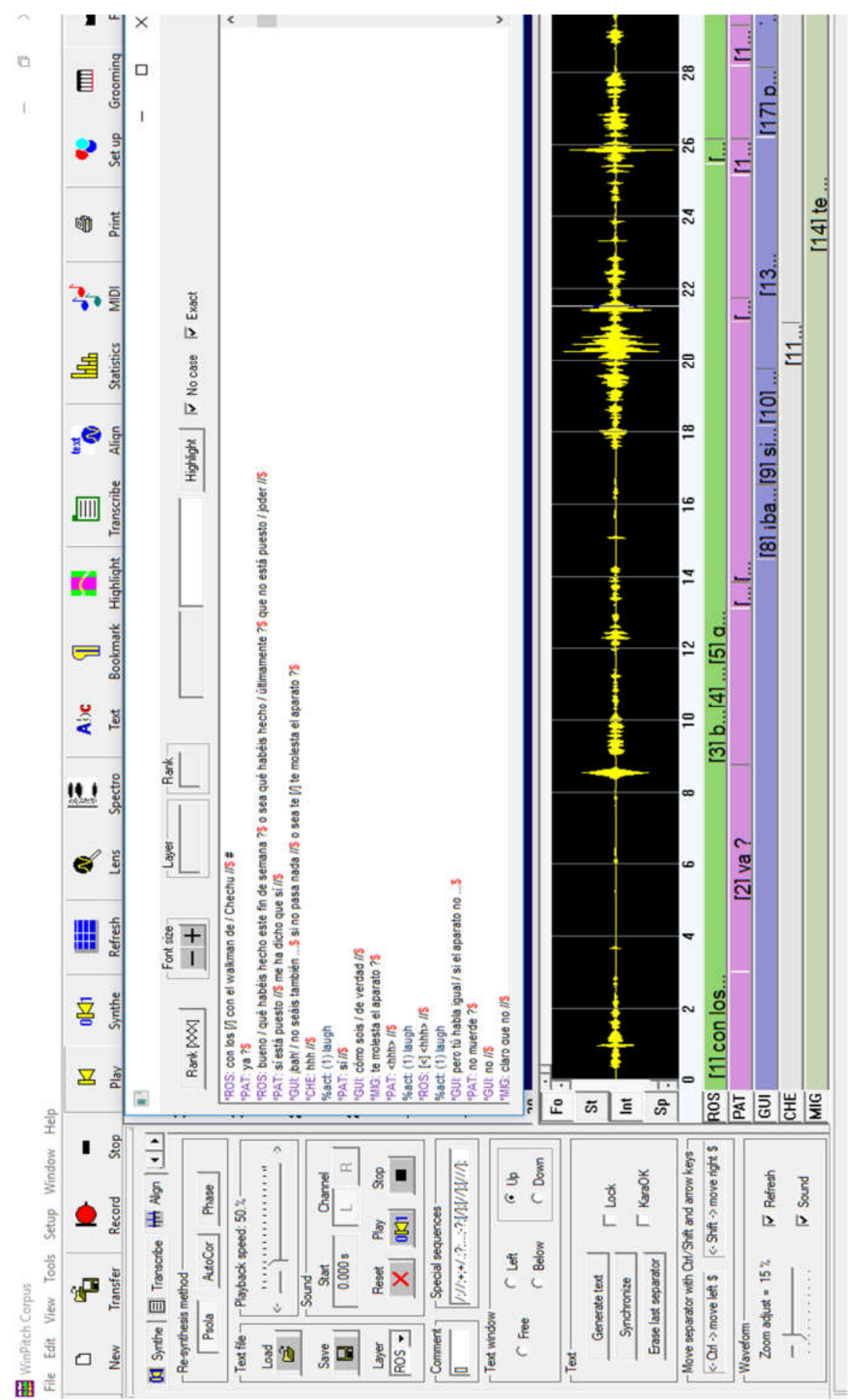

Figura 5 - Tela de alinhamento no DVD C-ORAL-ROM

(CRESTI \& MONEGLIA, 2005) 
Todas essas informações que trouxemos sobre o C-ORAL-ROM são válidas para as quatro línguas do projeto e serviram de parâmetro para a construção do corpus em PB, como explicaremos mais adiante. Na sequência, apontaremos alguns dados específicos do corpus em espanhol.

\subsubsection{A língua espanhola no C-ORAL-ROM}

O corpus de língua espanhola do C-ORAL-ROM foi elaborado por uma equipe de pesquisadores da Universidad Autónoma de Madrid (UAM), sob coordenação do professor Antonio Moreno Sandoval, no Laboratorio de Lingüística Informática (LLI UAM) ${ }^{23}$.

Em outros projetos de constituição de corpora orais da língua espanhola, a modalidade textual predominante é a entrevista semidirigida, sempre com a presença do entrevistador, além de um embasamento teórico/metodológico claramente sociolinguístico, em que a prioridade é a diversidade diatópica e de perfis socioculturais dos Falantes. Nossa escolha pelo C-ORAL deveu-se à priorização da diversidade diafásica e à espontaneidade das falas.

Quanto às normas de transcrição ortográfica, respeitaram-se as orientações da Real Academia Española (RAE). Por exemplo, as siglas foram grafadas com todas as letras maiúsculas sem pontos finais (IVA, ONG); foram incluídas, tanto nos textos, como no glossário que se elaborou em anexo ao corpus, Palavras que não estavam registradas na $\mathrm{RAE}$, mas que apareceram com frequência nos textos orais (como porfa, finde, pafeto); números foram transcritos em forma de numerais, exceto os que formam parte de nomes próprios ou fórmulas matemáticas e os números romanos foram mantidos; também se mantiveram as regras da RAE para as iniciais maiúsculas; não foram usadas Palavras em itálico nas transcrições; Palavras estrangeiras que foram pronunciadas na língua estrangeira foram transcritas mantendo a ortografia original de cada língua. Já as que eram pronunciadas adaptadas ao espanhol, eram transcritas seguindo a RAE. Criou-se uma lista de interjeições, e na transcrição elas aparecem com pontos de exclamação (¡Ah! ¡Anda! ¡Jolines! ¡Ojo ¡Coño! ¡Madre mía!).

Selecionamos, para análise, dezesseis arquivos do C-ORAL-ROM para compor nosso subcorpus em espanhol, que descrevemos abaixo.

\footnotetext{
${ }^{23}$ Para demais informações, consultar: http://www.lllf.uam.es/ESP/. Acesso 17 dez 2016.
} 


\subsubsection{Subcorpus em EP}

Para a análise das interações em EP em nossa tese, selecionamos, como já dito acima, dezesseis textos, com um total de aproximadamente 117 minutos de gravação e 25.000 Palavras. Como se verá, tentamos manter a maior equidade possível entre as extensões dos textos em ambas as línguas ${ }^{24}$. Os textos selecionados foram:

(i) seis conversas em contextos familiares/privados;

(ii) cinco diálogos em contextos familiares/privados;

(iii) cinco diálogos públicos.

\begin{tabular}{|c|c|c|}
\hline Contexto & Arquivo & Metadados \\
\hline \multirow{4}{*}{$\begin{array}{l}\text { A) Contexto } \\
\text { familiar/privado }\end{array}$} & efamcv02 & $\begin{array}{l}\text { Participantes e situação: conversa entre } \\
\text { familiares (duas donas de casa, um carpinteiro, } \\
\text { uma professora e um estudante) conversando } \\
\text { sobre hospitais, médicos e iogurtes. } \\
\text { Lugar: sala de casa de um dos participantes. } \\
\text { Duração e número de Palavras: 7'14"'-1554. }\end{array}$ \\
\hline & efamcv03 & 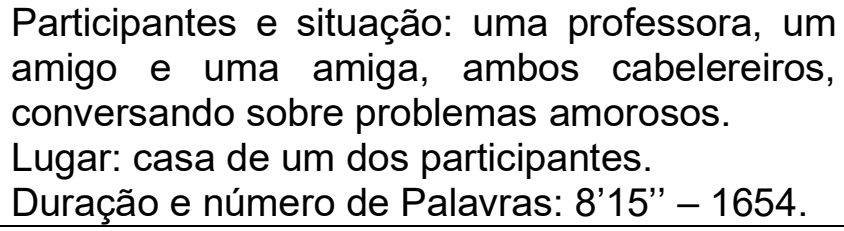 \\
\hline & efamcv05 & $\begin{array}{l}\text { Participantes e situação: conversa entre uma } \\
\text { telefonista, um instalador de ar condicionado e } \\
\text { um mestre de obras, sobre casamento, aborto, } \\
\text { bar e família. } \\
\text { Lugar: casa de um dos participantes. } \\
\text { Duração e número de Palavras: 6'49" - } 1528 \text {. }\end{array}$ \\
\hline & efamcv07 & $\begin{array}{l}\text { Participantes e situação: três mulheres } \\
\text { (vendedoras) e dois homens (um roteirista e um } \\
\text { estudante), todos amigos, conversando sobre } \\
\text { família e amigos. } \\
\text { Lugar: loja de roupas íntimas. } \\
\text { Duração e número de Palavras: 6'10" - } 1593 \text {. }\end{array}$ \\
\hline
\end{tabular}

\footnotetext{
${ }^{24}$ A diferença na quantidade de minutos de gravação dos dois corpora deve-se a que alguns áudios em PB têm períodos maiores de silêncios, como, por exemplo, o arquivo bfamdl04_Temp.
} 


\begin{tabular}{|c|c|c|}
\hline & efamcv10 & $\begin{array}{l}\text { Participantes e situação: quatro estudantes } \\
\text { (três mulheres e um homem), conversando } \\
\text { sobre amigos e relacionamentos. } \\
\text { Lugar: universidade. } \\
\text { Duração e número de Palavras: } 6{ }^{\prime} 24^{\prime \prime}-1568 \text {. }\end{array}$ \\
\hline & efamcv15 & $\begin{array}{l}\text { Participantes e situação: uma mulher e dois } \\
\text { homens, todos funcionários do banco, } \\
\text { conversando sobre viagens. } \\
\text { Lugar: banco } \\
\text { Duração e número de Palavras: 7'04" - } 1537 \text {. }\end{array}$ \\
\hline \multirow{5}{*}{ A.2) Diálogos: } & efamdl01 & $\begin{array}{l}\text { Participantes e situação: uma professora e uma } \\
\text { aposentada conversando sobre atividades para } \\
\text { distração (cursos de música e de computação) } \\
\text { enquanto tomam café. } \\
\text { Lugar: casa de uma delas. } \\
\text { Duração e número de Palavras: 6'31"' - } 1574 \text {. }\end{array}$ \\
\hline & efamdl08 & $\begin{array}{l}\text { Participantes e situação: conversa entre duas } \\
\text { amigas pós-graduandas sobre montanhas, } \\
\text { feriado e cachorros. } \\
\text { Lugar: universidade. } \\
\text { Duração e número de Palavras: 6'34" - } 1578 \text {. }\end{array}$ \\
\hline & efamdl19 & $\begin{array}{l}\text { Participantes e situação: esposa (secretária) e } \\
\text { marido (decorador) conversando sobre reforma } \\
\text { de casa. } \\
\text { Lugar: casa dos participantes. } \\
\text { Duração e número de Palavras: 6'23" - } 1523 \text {. }\end{array}$ \\
\hline & efamdl20 & $\begin{array}{l}\text { Participantes e situação: um escritor e um } \\
\text { jornalista conversando sobre feriados, } \\
\text { encontros, academia e teatro. } \\
\text { Lugar: escritório. } \\
\text { Duração e número de Palavras: } 8^{\prime} 01^{\prime \prime}-1538 .\end{array}$ \\
\hline & efamdl33 & $\begin{array}{l}\text { Participantes e situação: uma dona de casa e } \\
\text { uma cabelereira conversando sobre pessoas } \\
\text { famosas e futebol. } \\
\text { Lugar: sala da casa de uma delas. } \\
\text { Duração e número de Palavras: } 7^{\prime} 11^{\prime \prime}-1621 \text {. }\end{array}$ \\
\hline \multirow{3}{*}{$\begin{array}{l}\text { B) Contexto } \\
\text { público }\end{array}$} & epubdl04 & $\begin{array}{l}\text { Participantes e situação: um camponês } \\
\text { (comprador) e um vendedor trocando produtos } \\
\text { e conversando sobre compra de petróleo. } \\
\text { Lugar: escritório. } \\
\text { Duração e número de Palavras: } 7 \text { '11" }^{\prime}-1499 \text {. }\end{array}$ \\
\hline & epubdl06 & $\begin{array}{l}\text { Participantes e situação: uma dona de casa e } \\
\text { um médico conversando sobre o próximo } \\
\text { feriado e sobre uma tia, durante uma } \\
\text { massagem. } \\
\text { Lugar: clínica de massagem. } \\
\text { Duração e número de Palavras: } 8^{\prime} 13^{\prime \prime}-1530 \text {. }\end{array}$ \\
\hline & epubdl07 & $\begin{array}{l}\text { Participantes e situação: entrevista de quatro } \\
\text { mulheres (uma dona de casa, uma construtora }\end{array}$ \\
\hline
\end{tabular}




\begin{tabular}{|l|l|l|}
\hline & $\begin{array}{l}\text { e duas assistentes sociais) sobre oferta de } \\
\text { trabalho para imigrantes. } \\
\text { Lugar: centro cultural. } \\
\text { Duração e número de Palavras: 8'54" - 1555. }\end{array}$ \\
\cline { 2 - 3 } & $\begin{array}{l}\text { Participantes e situação: dois colegas de } \\
\text { trabalho, engenheiros, conversando sobre } \\
\text { carros e jogos de videogame. } \\
\text { Lugar: escritório (intervalo). } \\
\text { Duração e número de Palavras: 8'54" - 1523. }\end{array}$ \\
\cline { 2 - 3 } & $\begin{array}{l}\text { Participantes e situação: uma professora e um } \\
\text { estudante, em uma aula sobre computação. } \\
\text { Lugar: sala de aula. } \\
\text { Duração e número de Palavras: 8'31"' - 1550. }\end{array}$ \\
\hline
\end{tabular}

Figura 6 - Arquivos e metadados do subcorpus em EP

Como foi dito anteriormente, o C-ORAL-ROM serviu de referência metodológica para a criação de um corpus comparável em PB, o C-ORAL-BRASIL. É sobre ele que falaremos a seguir.

\subsection{O Projeto C-ORAL-BRASIL}

Para nossa análise do PB, utilizamos alguns textos do corpus do projeto CORAL-BRASIL - Corpus do português brasileiro falado informal25, compilado e organizado de 2007 a 2012 por uma equipe de professores e estudantes de graduação e pós-graduação no Núcleo de Estudos em Linguagem, Cognição e Cultura (NELC) e no Laboratório de Estudos Empíricos e Experimentais da Linguagem (LEEL), ambos da Faculdade de Letras da Universidade Federal de Minas Gerais (FALE/UFMG), sob a coordenação dos professores Tommaso Raso e Heliana Mello. Toda a pesquisa foi publicada em um livro com DVD (RASO \& MELLO, 2012) que, além dos arquivos de áudio, traz também anotação gramatical, especificações do corpus, medidas estatísticas e listas de frequência de Palavras, além do arquivo do livro em PDF.

Segundo Mello (2012), apesar de que nos últimos anos a Linguística de Corpus no Brasil tem se expandido, ainda há poucas pesquisas baseadas em dados reais da língua em uso no país, apesar de a tradição dos estudos linguísticos, principalmente na área da Sociolinguística Variacionista, fazer referência a seus bancos de dados como corpora. No entanto, a maioria desse banco de dados não é

\footnotetext{
${ }^{25}$ http://www.C-ORAL-BRASIL.org/. Acesso: 16 set 2016.
} 
computadorizada e há um grande deficit de textos escritos e orais disponibilizados eletronicamente quando comparados aos de outros países. Os principais corpora de língua portuguesa, sejam escritos ou orais, são de Portugal, e os produzidos no Brasil geralmente são desenvolvidos por grupos de pesquisas sobre o processamento da linguagem natural, Linguística Computacional e Lexicografia. Outro dado importante trazido pela autora é que "[...] a maior parte dos corpora produzidos no Brasil são escritos, principalmente com material pertinente de jornais e gêneros acadêmicocientíficos." (MELLO, 2012, p. 33).

É nesse cenário que o C-ORAL-BRASIL foi vislumbrado e compilado. Seu objetivo principal é compor com o C-ORAL-ROM, corpus europeu das quatro principais línguas românicas europeias, recurso linguístico computadorizado que permita estudos teóricos e aplicados da fala espontânea, com base empírica, pautada pela segmentação do fluxo sonoro em unidades formais correspondentes a unidades tonais. (MELLO, 2012, p. 33)

O corpus do C-ORAL-BRASIL é constituído por gravações de 362 Falantes, sendo metade mulheres e metade homens, com idades entre 18 e 60 anos. A diatopia representada é a mineira, em especial a da região metropolitana de Belo Horizonte.

A escolha desse corpus para análise em nossa pesquisa deve-se a vários fatores, dentre eles o fato de o C-ORAL-BRASIL ser "[...] um corpus balanceado, representativo das três principais tipologias da fala - diálogos, monólogos e conversações -, em contextos públicos e privados" (MELLO, 2012, p. 51). Um dado importante é que:

As situações de gravações foram as mais variadas possíveis, incluindo desde a execução de tarefas domésticas a trabalho em obra de construção civil, partida de futebol, garçons em uma festa, dentre outras. Não houve nenhuma gravação de fala roteirizada ou direcionada por tarefas propostas pela equipe do projeto. Essa multitude de cenários interativos garantiu a representatividade diafásica do corpus (MELLO, 2012, p. 51).

Essa variação diafásica explicita a perspectiva pragmática do corpus, em que é fundamental diferenciar o comportamento verbal em variados contextos situacionais, sendo o tema das interações, por exemplo, que é importante em estudos do léxico, um fator menos importante aqui. Segundo Raso (2012, p. 63), "[...] diferentes Falantes cumprem a mesma atividade sem uma apreciável variação estrutural, e a mudança 
de tópico em bate-papos ou entrevistas não gera variação ilocucionária ou estrutural". Um dado que merece destaque é que, na construção desse corpus, houve um máximo esforço para evitar bate-papos e entrevistas, isto é, evitar situações em que a única atividade dos participantes seria falar, já que essas situações são as mais documentadas em corpora orais. Priorizaram-se, portanto, gravações de interações dinâmicas, como em carros em movimento, amigos jogando sinuca ou futebol, pessoas preparando o almoço, uma compra em uma farmácia, uma aula de ginástica, amigas fazendo compras no mercado, funcionárias limpando a casa, etc. Por isso é que, assim como no C-ORAL-ROM, a unidade de segmentação de todo o corpus é o enunciado, cujas fronteiras são geralmente determinadas por quebras prosódicas (por isso também a importância de escutar os áudios e não apenas ter acesso às transcrições).

Em nossa análise, é essencial considerar essa naturalidade nas interações do corpus, uma vez que, entre outras características, na fala espontânea "[...] unidades autônomas sem verbo aparecem em cerca de $30 \%$ dos casos [...]. Portanto, todas as definições baseadas na estrutura por orações e na predicação resultam não adequadas [...]" (RASO, 2012, p. 76). Essa constatação vem ao encontro de nossa teoria, que não considera a sentença como unidade de estudo (nem a tradicional estrutura SVO), mas sim o Ato Discursivo, sem ordens básicas.

Todas as gravações do corpus estão transcritas e apresentam um cabeçalho no qual se encontram metadados, com as mesmas informações das fichas do CORAL-ROM. Da mesma maneira que fizemos com as informações dos metadados do C-ORAL, aqui também adaptamos as fichas, traduzindo-as do inglês para o PB e mantendo somente as informações necessárias para nossa pesquisa. Desse modo, cada transcrição selecionada para nosso corpus está acompanhada por uma ficha simplificada de metadados como a que segue:

Arquivo: bfamdl02.txt

Participantes e situação: Um moço e uma moça, estudantes de graduação, conversando enquanto embalam um equipamento de gravação.

Lugar: Universidade

Duração e número de Palavras: 7' 26" - 1581

Figura 7 - Exemplo de adaptação da ficha de metadados do C-ORAL-BRASIL 
Os textos são transcritos no formato Childes-Clan (MACWHINNEY, 2000, apud MELLO, 2012), implementado para a anotação prosódica (MONEGLIA \& CRESTI, 1997). Igualmente ao que ocorre no C-ORAL, aqui o corpus também está alinhado por enunciados (barra dupla) e em unidades tonais (barra simples) e são marcados também os enunciados interrompidos (+) e os retractings ([/]). Vejamos como exemplo um fragmento de texto transcrito:

*BEL: [10] <talvez as pilhas / não> //

*BAL: [11] <que que eu tava pensando \&a [/6] que que> eu tava pensando aqui // [12] \&a [/1] não // [13] as pilhas / eu coloquei aqui // [14] as recarregáveis / tão aqui // *BEL: [15] ah / tá //

*BAL: [16] tem essas aqui / que foram usadas / só que a gente não sabe ainda se elas acabaram / ou não / <se elas têm muito> tempo de vida / etcetera //

*BEL: [17] <hum hum> // [18] tá // [19] <isso é o> regarregador //

*BAL: [20] <então vamo \&deix $>+[21]$ \&reca + [22] <inclusive pode \& $>+$

*BEL: [23] < pode guardar junto $><$ delas $>/ /$

*BAL: [24] <é> / é //

*BEL: [25] tem outro // [26] ou é só <esse> //

*BAL: [27] <não> / é só esse / e tem a tomada dele ali //

*BEL: [28] é a [/1] a <cinza> //

*BAL: [29] <essa \&bra> [/2] essa cinza aí // [30] um cuidado / que cês têm que tomar $1<\mathrm{Bel}>+$

${ }^{*} \mathrm{BEL}:$ [31] <ah> // [32] fio // [33] né //

*BAL: [34] não / nem é só isso não //

*BEL: [35] ahn //

*BAL: [36] a Estefânia / apanhou // [37] ela não conseguiu carregar a pilha por causa que isso aqui tava em duzentos-e-vinte // [38] tá vendo / a setinha tem que tá no centoe-dez //

*BEL: [39] apanhou e quase pôs fogo na casa / <não > //

*BAL: [40] <não> / não // [41] se < você ligar um aparelho> +

*BEL: [42] <ah / se fosse o contrário> //

*BAL: [43] é // [44] se fosse o contrário / pegaria fogo // [45] cê sabe que aquelas caixinhas ali / ela [/1] eu descobri ontem /

*BEL: [46] uhn //

Figura 8 - Exemplo de transcrição do C-ORAL-BRASIL

Sabe-se que uma das dificuldades de compilação e análise de corpora orais é a qualidade das gravações, que pode ser prejudicada por ruídos externos, interrupções e falta de equipamentos compatíveis com os objetivos da pesquisa. No entanto, no C-ORAL-BRASIL utilizaram-se somente as gravações consideradas de excelente qualidade acústica, que foram possíveis graças a equipamentos muito 
sofisticados, como microfones sem fio e mixer ${ }^{26}$. Além disso, toda a equipe responsável pelas gravações recebeu treinamento em oficinas para a utilização adequada dos equipamentos. É importante também ressaltar que as especificações do corpus escolhido seguem as orientações internacionais do Text Encoding Initiative $(\text { TEI })^{27}$.

As gravações foram feitas entre 2006 e 2011, mas principalmente entre 2008 e 2010. Até 2017, o corpus, ainda em construção, era composto por aproximadamente 200 textos e 300.000 Palavras, divididos em uma metade formal (em fase de coleta) e uma metade informal (concluída). A metade informal se divide em um domínio privado/familiar (80\%) e um domínio público (20\%) e cada domínio está subdividido nas três tipologias de fala citadas acima (1/3 para cada gênero discursivo). Além disso, todas as gravações foram autorizadas pelos informantes, por meio de assinatura de termo de consentimento informado, aprovado pelo Comitê de Ética da UFMG.

As transcrições ortográficas foram feitas por uma equipe constituída por alunos de graduação e pós-graduação vinculados ao projeto de pesquisa, com conhecimento teórico sobre a Teoria da Língua em Ato (base teórica do projeto), a qual participou de treinamentos rigorosos (através de minicursos e workshops

O transcritor dos textos do C-ORAL-BRASIL deveria registrar exatamente aquilo que havia sido pronunciado pelo Falante, com o objetivo de evitar a reprodução de uma norma escrita fortemente interiorizada por ele (transcritor). Os sinais de convenções que foram usadas nas transcrições são os mesmos que usados no CORAL-ROM.

${ }^{26}$ Um mixer, de maneira genérica, é um equipamento usado para combinar (ou "mixar") várias fontes de som, de forma a somá-las em um único sinal de saída. Com ele também é possível alterar parâmetros do som, como volume, timbre e faixa dinâmica. Um exemplo simples de uso de um mixer seria permitir que sinais originados de dois microfones diferentes pudessem ser ouvidos simultaneamente em um único alto-falante.

${ }^{27}$ Segundo informações do site <http://www.tei-c.org/index.xml>, acesso em 29 abril 2017, a Iniciativa de Codificação de Texto (TEI) é uma iniciativa coletiva, sem fins lucrativos, composta por instituições acadêmicas, projetos de pesquisa e estudiosos individuais de todo o mundo, que desenvolve e mantém um padrão para a representação de textos em formato digital, principalmente nas áreas das ciências humanas, ciências sociais e linguística. Desde 1994, as Diretrizes TEI têm sido muito utilizadas por bibliotecas, museus, editores e demais pesquisadores. Além das próprias Diretrizes, são fornecidos também recursos variados e treinamentos para a aprendizagem de TEl, informações sobre projetos usando o TEI, uma bibliografia de publicações relacionadas com TEI e software desenvolvido para ou adaptado ao TEI. 
Outras observações sobre os critérios de transcrição são: as interjeições e onomatopeias são transcritas conforme a pronúncia (ex. toc toc toc, hum, ahn), siglas e acrônimos são transcritos ortograficamente e com letras maiúsculas caso pronunciados como Palavras e com letras minúsculas se pronunciados soletrando-se as letras (ex. no CEFET, na uefeemegê), as Palavras estrangeiras são transcritas de acordo com a ortografia oficial da língua portuguesa (ex. estresse, estéreo), a não ser que fique claro que a pessoa esteja falando com pronúncia estrangeira (ex. stereo) e se a palavra estrangeira é pronunciada com erro, transcreve-se a forma conforme pronunciada e registra-se o erro nos comentários. Alguns critérios não foram ortográficos, e correspondem principalmente a alguns fenômenos em vias de gramaticalização ou lexicalização. Os principais são: aférese (ex. bora < embora, brigado < obrigado); reprodução na transcrição dos fenômenos relativos à conjugação verbal (ex. xá < deixa, ó < olha, empurramo < empurramos); respeito à pronúncia de Palavras sem a desinência de plural (ex. os carro) ou com marca de plural em Palavras invariáveis (ex. ques menino lindo) e manutenção das contrações de preposições com artigos (ex. pruma, pros). Além de todos esses critérios, o corpus do C-ORAL-BRASIL foi validado duas vezes, a fim de garantir o máximo possível de coerência e sistematicidade internas.

Como se pôde constatar, todo o material do C-ORAL-BRASIL é comparável ao C-ORAL-ROM, por usar os mesmos embasamentos teóricos e os mesmos procedimentos metodológicos, o que o torna adequado a um estudo de comparação entre duas ou mais línguas, como é nosso caso.

Os arquivos de áudio estão disponíveis no DVD que acompanha o livro CORAL-BRASIL I (MELLO \& RASO et al. 2012). A professora Heliana Mello autorizou que disponibilizássemos os 16 arquivos usados nas nossas análises para os leitores desta tese, em formato MP3 e que disponibilizamos na pasta do Google Drive indicada na Introdução. Não temos a permissão para compartilhar os áudios em espanhol, e os arquivos estão em um formato criptografado, por isso não os anexaremos neste trabalho.

A seguir, mostramos os arquivos que selecionamos do C-ORAL-BRASIL para compor nosso subcorpus em PB. 


\subsubsection{O subcorpus em $P B$}

Para a análise das interações em PB em nossa tese, selecionamos dezesseis textos, com um total de aproximadamente 155 minutos de gravação e 25.000 Palavras. Os textos selecionados foram:

(i) sete conversas em contextos familiares/privados;

(ii) cinco diálogos em contextos familiares/privados;

(iii) quatro diálogos públicos.

A seguir listamos os arquivos selecionados com as respectivas adaptações das fichas de metadados disponíveis nas versões do C-ORAL-BRASIL.

\begin{tabular}{|c|c|c|}
\hline Contexto & Arquivo & Metadados \\
\hline \multirow{4}{*}{$\begin{array}{l}\text { A) Contexto } \\
\text { familiar/privado }\end{array}$} & bfamcv02 & $\begin{array}{l}\text { Participantes e situação: três irmãs } \\
\text { conversando sobre a organização do } \\
\text { casamento da filha de uma delas. } \\
\text { Lugar: casa de uma das participantes. } \\
\text { Duração e número de Palavras: } 7^{\prime} \text { 51" - } \\
1736 \text {. }\end{array}$ \\
\hline & bfamcv12 & $\begin{array}{l}\text { Participantes e situação: mãe (professora) e } \\
\text { dois filhos conversando sobre melhorias na } \\
\text { casa. } \\
\text { Lugar: casa de um dos participantes. } \\
\text { Duração e número de Palavras: } \text { 8' }^{\prime \prime} 15^{\prime \prime} \text { - } \\
\text { 1393. }\end{array}$ \\
\hline & bfamcv13 & $\begin{array}{l}\text { Participantes e situação: pacientes do } \\
\text { hospital (um operador de máquinas, um } \\
\text { carregador e um agricultor) conversando } \\
\text { entre si e com um amigo visitante (físico) } \\
\text { sobre os motivos de estarem ali. } \\
\text { Lugar: hospital. } \\
\text { Duração e número de Palavras: 6' 10" - } \\
\text { 1495. }\end{array}$ \\
\hline & bfamcv15 & $\begin{array}{l}\text { Participantes e situação: oito mulheres, } \\
\text { assistentes de limpeza, conversando sobre } \\
\text { desgraças e outros tópicos, na hora do } \\
\text { intervalo. }\end{array}$ \\
\hline
\end{tabular}




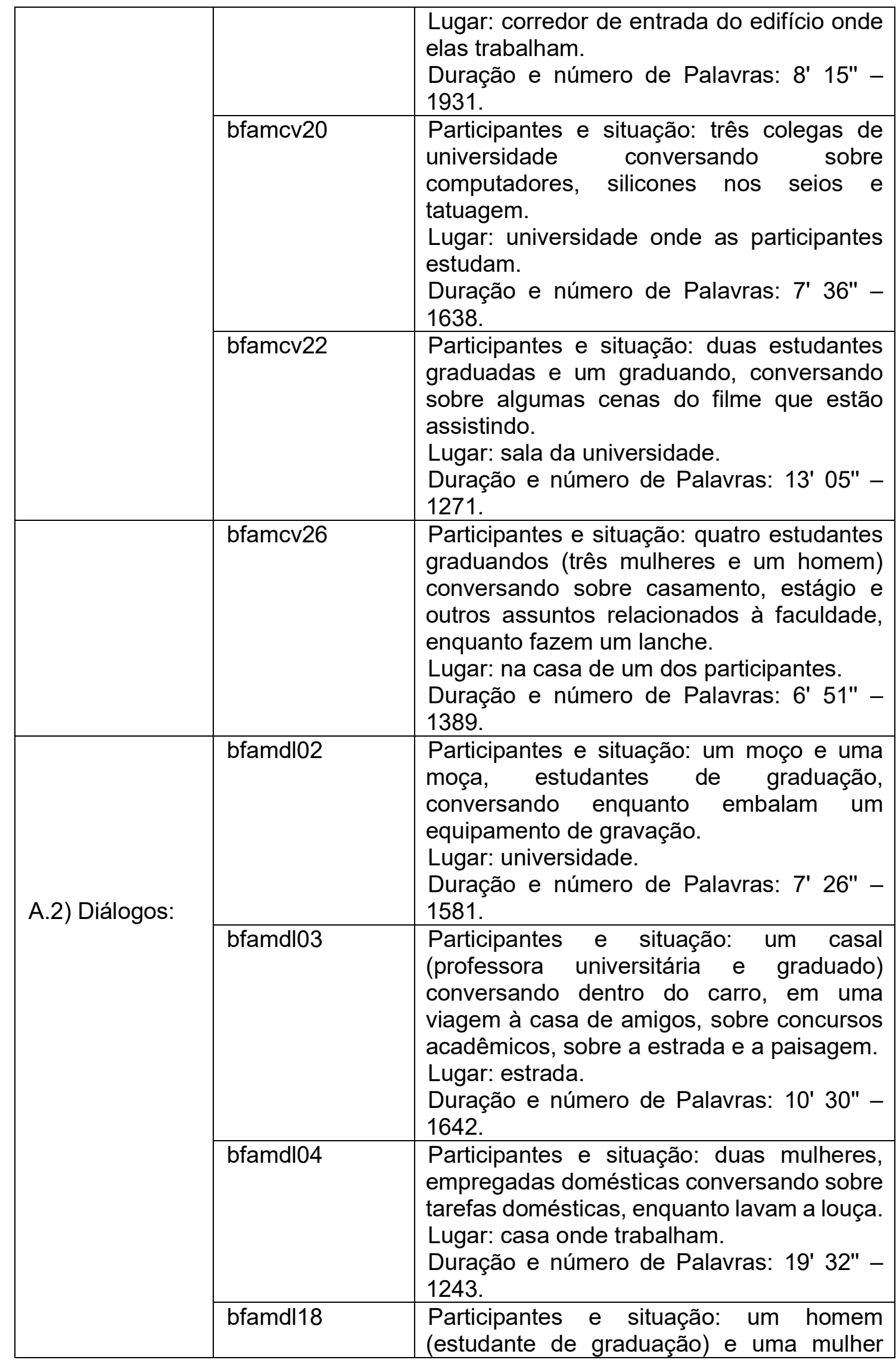




\begin{tabular}{|c|c|c|}
\hline & & $\begin{array}{l}\text { (recepcionista de um hospital) conversando } \\
\text { sobre festas, família e homossexualidade. } \\
\text { Lugar: casa de um dos participantes. } \\
\text { Duração e número de Palavras: } 7{ }^{\prime} \text { 58" - } \\
1457 \text {. }\end{array}$ \\
\hline & bfamdl21 & $\begin{array}{l}\text { Participantes e situação: dois estudantes de } \\
\text { graduação, conversando sobre documentos } \\
\text { necessários para um programa de } \\
\text { intercâmbio e sobre algumas atrações } \\
\text { turísticas da Itália. } \\
\text { Lugar: universidade. } \\
\text { Duração e número de Palavras: } 10^{\prime} \text { 20" - } \\
1614 \text {. }\end{array}$ \\
\hline \multirow[t]{4}{*}{$\begin{array}{l}\text { B) Contexto } \\
\text { público }\end{array}$} & bpubdl01 & $\begin{array}{l}\text { Participantes e situação: um pedreiro e um } \\
\text { agrônomo conversando sobre uma } \\
\text { construção que está sendo feita na casa de } \\
\text { campo de um deles. } \\
\text { Lugar: casa de um deles. } \\
\text { Duração e número de Palavras: } 10^{\prime} 02 " \text { - } \\
1617 \text {. }\end{array}$ \\
\hline & bpubdl02 & $\begin{array}{l}\text { Participantes e situação: uma mulher } \\
\text { comprando sandálias e um vendedor } \\
\text { mostrando-lhes as opções. } \\
\text { Lugar: loja de sapatos. } \\
\text { Duração e número de Palavras: } 15^{\prime} 45^{\prime \prime} \text { - } \\
1448 \text {. }\end{array}$ \\
\hline & bpubdl08 & $\begin{array}{l}\text { Participantes e situação: um professor e seu } \\
\text { supervisor se encontrando para falar sobre } \\
\text { tarefas. } \\
\text { Lugar: escola de idiomas. } \\
\text { Duração e número de Palavras: } 6{ }^{\prime} 47^{\prime \prime} \text { - } \\
1689 \text {. }\end{array}$ \\
\hline & bpubdl11 & $\begin{array}{l}\text { Participantes e situação: professor de inglês } \\
\text { e aluno, durante uma aula. } \\
\text { Lugar: laboratório de fonética. } \\
\text { Duração e número de Palavras: } 10^{\prime} \text { 20" - } \\
1811 .\end{array}$ \\
\hline
\end{tabular}

Figura 9 - Arquivos e metadados do subcorpus em português

É claro que nossa intenção foi apenas utilizar um recorte de situações possíveis da vida cotidiana, sem a pretensão de abarcar todas as possibilidades (o que, de fato, seria impossível). No entanto, acreditamos que o recorte feito contempla uma variedade diafásica bastante ampla, com contextos e participantes com perfis sociais bastante diferentes, o que possibilita que nossa análise seja uma amostra a 
mais próxima possível da linguagem usual, ao menos de uma variedade diatópica para cada uma das línguas em questão.

\subsection{Outros procedimentos metodológicos adotados}

Criados os subcorpora nas duas línguas, prosseguimos com os seguintes procedimentos metodológicos:

(a) passamos todas as transcrições para o formato do Word, para facilitar a busca por Palavras ou estruturas que nos interessavam;

(b) adaptamos as fichas de metadados para cada arquivo escolhido;

(c) analisamos manualmente o corpus em PB (transcrições alinhadas com os áudios), observando primeiramente as llocuções Declarativas e depois as Interrogativas, buscando inicialmente ocorrências em que houvesse alguma ordenação não icônica do ponto de vista tradicional, ou seja, que fosse diferente de SVO;

(d) das ocorrências encontradas em (c), selecionamos para análise somente as que seguiam os critérios que definimos nos objetivos;

(e) analisamos as ocorrências de (d), descrevendo quais posições e funções eram atribuídas a cada constituinte;

(f) recortamos os arquivos de áudio de cada uma das ocorrências exemplificadas no decorrer desta tese; para tanto, utilizamos o software Audacity;

(f) repetimos os mesmos procedimentos de (a) a (f) para o corpus em EP;

(g) comparamos os dados encontrados nas análises dos dois corpora.

Vale observar que, de acordo com a perspectiva teórica que adotamos, a GDF, somente as análises qualitativas são relevantes, e, por isso, esse tipo de análise será o principal critério nesta tese. No entanto, em alguns momentos de nossas análises, quando a análise dos dados nos mostrar uma diferença quantitativa considerável entre as duas línguas, esses dados serão apresentados também quantitativamente.

Algumas observações também são importantes: (i) decidimos reiniciar a numeração dos exemplos a cada capítulo, a partir do capítulo 3, para evitar números 
muito extensos (centesimais); (ii) entre os autores que fazem referência à GDF muitas vezes há divergências quanto ao uso de letras iniciais maiúsculas em algumas Palavras. Por isso, adotamos o seguinte critério: doravante usaremos letras maiúsculas em todas as Palavras que se referem a alguma camada dos Níveis da GDF, como, por exemplo, Falante, Destinatário, Expressão Linguística, Movimento, Ato Discursivo, etc., bem como para nos referirmos às funções pragmáticas (Tópico, Foco, Contraste), categoria pragmática (Ênfase), funções semânticas (Ativo, Inativo e Locativo), funções sintáticas (Sujeito e Objeto) e aos tipos de construções e moldes de Conteúdo e de Predicado; (iii) os esquemas de posições dos exemplos, embora apareçam em tabelas, não serão considerados como figuras; (iv) para facilitar a leitura dos exemplos, também optamos por apagar os números referentes aos turnos de cada participante (essa decisão também se justifica porque nem todas as transcrições apresentavam essa numeração); (v) para contextualizar melhor os arquivos de áudios recortados, deixamos aproximadamente 3 segundos anteriores e 3 segundos posteriores ao exemplo transcrito.

Apresentado o corpus e delimitada a metodologia, passemos às perguntas, objetivos iniciais e hipóteses desta pesquisa. Cabe reiterar aqui o que já antecipamos antes, que os objetivos da tese serão melhor explicados no final do capítulo 6 , quando já tivermos apresentado os conceitos teóricos pertinentes.

\subsection{Objetivos e hipóteses iniciais da pesquisa}

\subsubsection{Objetivos}

\subsubsection{Objetivo geral}

Nosso objetivo mais amplo é descrever e analisar, comparativamente, em PB e em EP, nas variedades presentes nos corpora escolhidos para esta pesquisa, quais são as estratégias de ordenação dos constituintes argumentais ou correferentes a argumentais (o que significa que excluiremos constituintes que sejam operadores ou modificadores) que expressam as funções pragmáticas (Tópico, Foco e Contraste) e duas das funções retóricas (Orientação e Esclarecimento), tendo como unidade de 
análise o Ato Discursivo ${ }^{28}$ (o que significa que analisaremos tanto constituintes oracionais como extraoracionais, ou seja, que estejam no nível da Expressão Linguística). Para tanto, adotaremos como referencial teórico a GDF.

\subsubsection{Objetivos específicos}

Todos os recortes feitos se justificam por termos a hipótese de que esses fatores selecionados sejam alguns dos que geram maiores diferenças de ordenação no $P B$ e no EP29. Dentre as especificidades a serem investigadas, pretendemos:

(i) confirmar se há ou não uma relação direta entre as funções pragmáticas e a ordenação dos constituintes em PB e em EP;

(ii) investigar se há outras motivações e/ou restrições para a ordenação dos constituintes, que não sejam as pragmáticas;

(iii) descrever como os constituintes argumentais de orações simples, de llocuções Declarativas e Interrogativas, com funções pragmáticas de Foco, Tópico e Contraste se organizam e são expressos em PB e em EP;

(iv) analisar como se marcam, nessas duas línguas, as funções retóricas de Orientação e Esclarecimento, observando principalmente recursos de correferencialidade.

Nossas hipóteses, ainda extremamente genéricas, são as seguintes:

1. Parece haver diferenças evidentes nas ordenações de alguns constituintes das duas línguas, principalmente no que se refere à posição dos Sujeitos, já que o PB parece ter maior restrição para a ordenação de constituintes com essa função que o EP;

\footnotetext{
${ }^{28}$ Os conceitos de Ato Discursivo, bem como as funções pragmáticas e retóricas às quais nos referimos aqui, serão explicados posteriormente. Por ora, basta-nos dizer que, embora um Ato Discursivo possa coincidir com uma unidade sintagmática, não nos deteremos em descrever as partes dos Sintagmas, como as relações entre determinantes e nomes, por exemplo.

29 Obviamente, um trabalho comparativo pressupõe também semelhanças entre as línguas comparadas. No entanto, não perdendo de vista nossa motivação inicial para esta pesquisa, sempre que necessário, privilegiaremos as diferenças.
} 
2. as diferenças de ordenações devem-se a determinadas restrições e a determinadas marcas morfossintáticas disponíveis ou não em ambas as línguas, como, por exemplo, o uso da preposição a como antecedente de alguns tipos de complementos verbais no EP;

3. as diferentes maneiras de marcar correferencialidade nas duas línguas, seja por pronomes fortes ou clíticos, seja por anáfora zero, podem ter relação com as intenções comunicativas dos Falantes e estão, portanto, atreladas a funções pragmáticas e discursivas;

4. pelas leituras teóricas e analíticas que já fizemos sobre a ordenação das Palavras em diferentes línguas e principalmente no PB, acreditamos que o PB dispõe de posições fixas no enunciado para alocar constituintes com as funções pragmáticas, sendo Tópico ocupando $\mathrm{Pl}^{\mathrm{l}}$ e Foco ocupando PF. Queremos confirmar essa interpretação e investigar se essas mesmas posições se mantêm para essas funções em EP;

5. as respostas mais típicas dadas às Interrogativas fechadas em PB parecem ser sintagmáticas, constituídas geralmente apenas pelo próprio verbo usado na pergunta, enquanto nas do EP se usam orações mais completas (com predicado e argumentos retomados por clíticos), enquanto no EP parece que os complementos verbais são mantidos, além de haver mais usos de sim. Nossa hipótese é que essa seja uma manifestação de parâmetros diferentes nas duas línguas em relação aos Objetos plenos ou nulos e que isso também influencia na ordenação dos constituintes;

6. há diferentes recursos nas duas línguas para destacar (enfatizar, contrastar) determinados constituintes.

Todas essas hipóteses serão detalhadas, esclarecidas, confirmadas ou refutadas ao longo da descrição dos fatores observados em cada língua. No capítulo seguinte, começamos nossa imersão teórica, apresentando, primeiro, alguns conceitos do Funcionalismo e, depois, a estrutura geral da GDF. 


\section{CAPÍTULO 2}

\section{ARQUITETURA GERAL DA GRAMÁTICA DISCURSIVO-FUNCIONAL}

Neste capítulo, trataremos das principais características da linha teórica que escolhemos para fundamentar este trabalho: a Gramática Discursivo-Funcional (GDF). Como se trata de uma teoria bastante ampla e complexa, preferimos apresentar apenas os conceitos fundamentais para os objetivos de análise que delimitamos neste trabalho, passando muito brevemente por outros conceitos, com a intenção apenas de situar o leitor dentro do marco teórico geral.

De maneira geral, podemos dizer que:

A GDF oferece um quadro estruturado dentro do qual as hipóteses linguísticas podem ser enunciadas e testadas. Ao mesmo tempo, ela fornece um quadro para a descrição de fenômenos linguísticos e, dessa forma, pode estar envolvida em todo o ciclo de pesquisa: da observação à predição, ao teste das predições por meio de novas observações, de volta a novas predições e assim por diante. (HENGEVELD \& MACKENZIE, 2012, p. 49).

Trata-se de uma teoria que começou a ser esboçada em 1997 pelo professor Kees Hengeveld ${ }^{30}$, do departamento de Linguística da Universidade de Amsterdã, a partir da Gramática Funcional desenvolvida principalmente por Simon Dik nos anos 1970. A teoria foi passando por reformulações e, em 2008, Hengeveld \& Mackenzie lançam o livro Functional Discourse-Grammar. A typologically-based theory of language structure, no qual se encontram as bases fundamentais da GDF atual. Os exemplos analisados pelos autores são amostras de várias línguas (inglês, húngaro, francês, espanhol, português, alemão, coreano, etc.), com base em gramáticas e estudos descritivos dessas línguas. Os autores também dizem que recorreram às suas intuições sobre as línguas que conhecem bem, pesquisando os dados dessas línguas, portanto, na internet. Eles nos alertam, ainda, para o fato de que as análises que propõem de fenômenos particulares devem ser tomadas apenas como indicativo e não como uma declaração definitiva da teoria em si. Em comparação com a

30 Muitas das publicações do professor podem ser consultadas em sua página pessoal: <http://home.hum.uva.nl/oz/hengeveldp/>. Acesso: 18 jun 2017. 
Gramática Funcional (GF), os autores dizem que a GDF tem uma orientação muito mais tipológica, enquanto a GF tem um caráter mais descritivo, sem a preocupação essencial de fazer generalizações translinguísticas.

No Brasil, podemos dizer que a GDF ainda é uma teoria não muito utilizada, tendo um de seus principais polos de estudo na Universidade Estadual Paulista (UNESP) Júlio de Mesquita Filho, no campus da cidade de São José do Rio Preto, $\mathrm{SP}$, onde, além de visitas, orientações e cursos ministrados pelos próprios criadores da teoria, existe, desde 2002, um grupo de pesquisa bastante produtivo coordenado pelos professores Roberto Camacho e Erotilde Goreti Pezatti (que realizou seu pósdoutorado em Amsterdã sob orientação do professor Hengeveld e se tornou um dos principais nomes de referência dessa teoria no Brasil) ${ }^{31}$.

Como teoria, a GDF é um desdobramento da Gramática Funcional no sentido mais amplo, considerando, no entanto, a noção de Ato Discursivo como unidade de análise, e não mais a Oração, como se vinha priorizando nas outras teorias até então (e como comentamos no capítulo anterior). É, desse modo, uma vertente teórica que entende as expressões linguísticas como resultantes de um conjunto de fatores contextuais, gramaticais e cognitivos. Porém, ambas as teorias (Gramática Funcional e Gramática Discursivo-Funcional) compartilham uma preocupação tipológica e, portanto, sistemática, de descrever as línguas naturais. É importante observar, no entanto, que para a GDF tanto a Formulação como a Codificação são processos que podem variar de língua para língua. "Isso significa que nenhuma categoria pragmática, semântica, morfossintática ou fonológica universal deve ser postulada até que sua universalidade tenha sido demonstrada por meio de pesquisa empírica" (SPÓSITO, 2012, p. 23). Essa é uma característica relevante para esta tese, que tem por objetivo comparar alguns parâmetros de ordenação em duas línguas distintas e próximas.

Todas as análises na GDF partem, como vínhamos apresentando, da intenção comunicativa dos Falantes e, por isso, o Ato Discursivo passa a ser a base para as unidades linguísticas de níveis mais baixos, como se verá a seguir, compreendendo elementos de ordem pragmática e semântica. Nesta teoria, considera-se, por exemplo, não apenas o conhecimento prévio de cunho linguístico dos participantes do processo de comunicação, mas também o conhecimento não

31 Mais informações sobre esse grupo de pesquisa podem ser obtidos no endereço <http://prope.unesp.br/grupos pesquisa/grupo detalhado.php?id grupo=0330801R1DMU3F>.

Acesso: 20 jan 2018. 
linguístico (conhecimento de mundo), além do conhecimento imediato (aquele captado através da situação comunicativa em que ocorre o evento) que pode ser, por sua vez, situacional (inferido da situação) ou textual (oriundo do que já foi comunicado linguisticamente). Em relação aos conhecimentos linguísticos dos participantes, não se consideram apenas aqueles relacionados à gramática da língua, à sua estruturação e ao seu léxico, mas consideram-se também seus conhecimentos pragmáticos.

Em termos de organização, a GDF está dividida em quatro níveis, ascendentes: o mais alto é o Interpessoal (ou pragmático), seguido do Representacional (ou semântico), depois do Morfossintático (ou estrutural) e por último, do Fonológico (ou articulatório). Essa arquitetura é, conforme Hengeveld \& Mackenzie (2005), motivada pelo postulado de que a eficiência de um modelo de gramática é proporcional à sua aproximação com o processamento cognitivo. Estudos psicolinguísticos (LEVELT, 1989, apud HENGEVELD \& MACKENZIE, 2008) demonstram que a produção linguística é um processo que se inicia com as intenções do Falante e termina com a articulação/realização da Expressão Linguística real (componente de expressão).

Por partir do Ato Discursivo como unidade de análise, a organização dessa gramática é do tipo Top-down, isto é, ela é um modelo descendente, que tem seu ponto de partida na cadeia mais alta da hierarquia linguística, que é a intenção do Falante, e passa por camadas até chegar ao Componente de Saída, que é a articulação. Sendo assim, para a GDF, um enunciado começa a ser formulado com a intenção comunicativa de uma mensagem, no Componente Conceitual. A partir daí, a mensagem, que ainda está em uma forma pré-linguística, passa para o Componente Gramatical. É nesse nível que ela passa a ter valores pragmáticos e semânticos e que é codificada em unidades formais nos níveis fonológico e morfossintático. Por fim, a mensagem é articulada no Componente de Saída, que gera as expressões acústicas ou escritas.

Dizer que o enunciado tem seu ponto inicial no Componente Conceitual significa admitir o pressuposto de que são os objetivos comunicativos dos usuários da língua que determinam as características dos enunciados. Acredita-se que usuários são altamente competentes no conhecimento das unidades da língua (lexemas, fonemas, constituintes sintáticos) e das maneiras de combiná-las (em Atos Discursivos, Proposições, Orações e Frases Entonacionais) a fim de alcançar o sucesso na interação com outros usuários. 
Esse conhecimento é estável e essa estabilidade indica que a língua é sistemática e por isso passível de ser descrita de modo explícito e formal. Além disso, a sistematicidade também permite a comparação entre línguas, revelando tendências universais na estrutura linguística, que podem ser realizadas linguisticamente de diferentes maneiras nas línguas particulares, ao modo do que se faz na tipologia linguística. Sendo assim, a GDF é uma teoria voltada tanto para a forma como para a função, sendo considerada uma linha funcionalista intermediária. $\mathrm{O}$ objeto de estudo da GDF, portanto, são todas as manifestações linguísticas sistemáticas que refletem necessidades comunicativas.

Apesar de considerar o contexto em que a comunicação ocorre, o foco de análise da GDF é o âmbito individual e psicológico do usuário e não o social (por isso não é uma gramática do discurso). Para conseguir descrever esse objeto, a GDF é constituída pelos quatro componentes que vemos no quadro a seguir: O Conceitual, o Gramatical, O Contextual e o de Saída. 


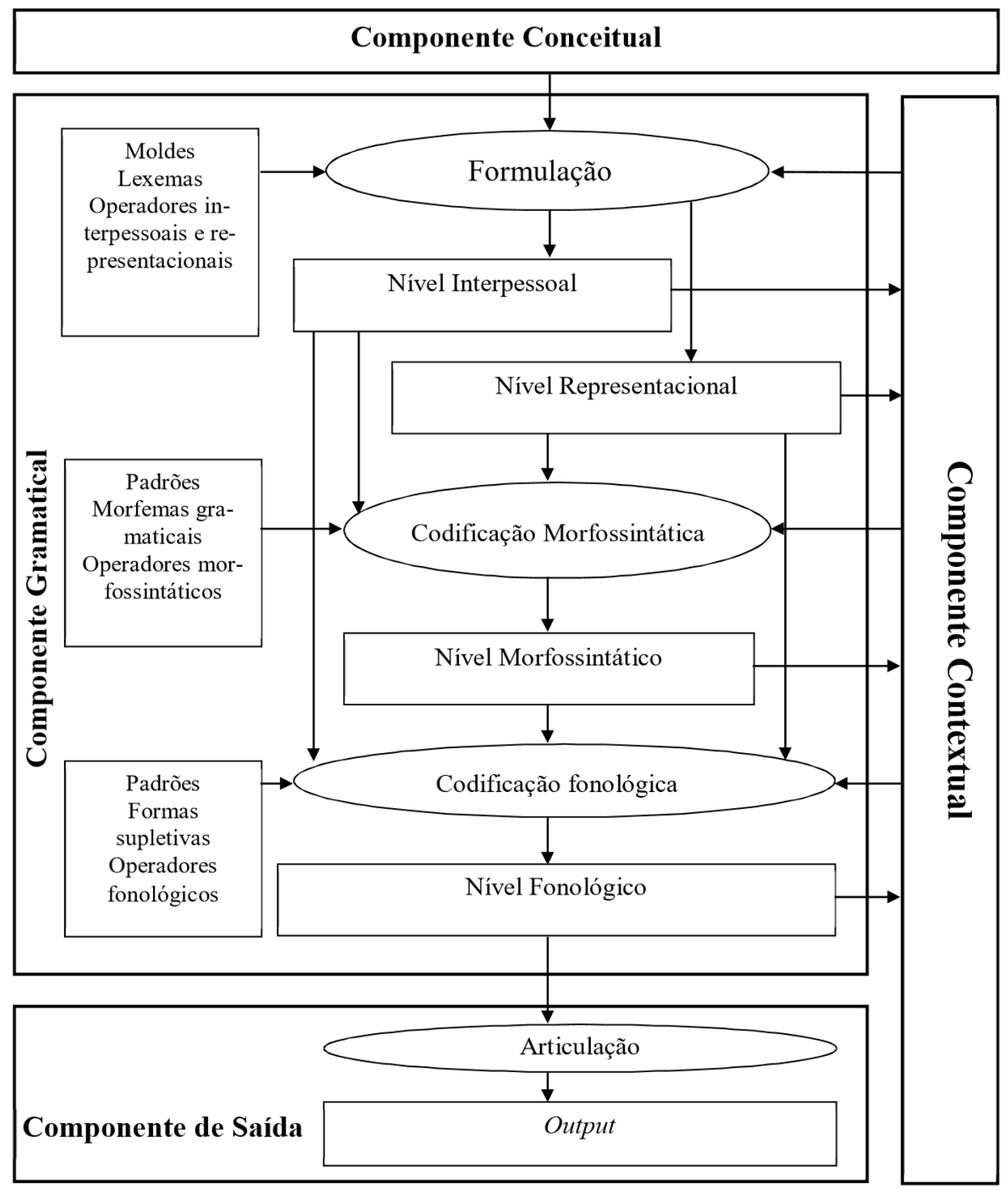

Figura 10 - Layout geral da GDF

In: Pezatti, 2014, p. 75 (adaptado de HENGEVELD \& MACKENZIE, 2008).

A partir da figura acima, podemos visualizar o que já dissemos anteriormente: o Componente Conceitual ocupa a posição mais alta do esquema, pois é aí que ocorrem a intenção comunicativa (de, por exemplo, avisar sobre um perigo) e as conceitualizações relevantes dos eventos extralinguísticos (por exemplo, a percepção do evento causador de perigo). Assim, em um enunciado como Tem um cachorro 
enorme nesta casa!, temos uma intenção comunicativa de emitir um alerta. Essa intenção é o que constitui o Componente Conceitual do nosso exemplo e só será realizada/traduzida nos níveis Interpessoal e Representacional, como veremos mais adiante.

O Componente Contextual contém informações imediatas (de curto prazo) e de longo prazo sobre a interação. As imediatas referem-se a um enunciado em particular que é emitido e que influenciará as escolhas dos próximos enunciados, enquanto as de longo prazo referem-se à memória discursiva do usuário sobre interações e situações correntes e que influenciam a Formulação e a Codificação. $O$ Componente Contextual, portanto, disponibiliza antecedentes, referentes visíveis e participantes do ato de fala que podem influenciar a composição do Ato Discursivo subsequente.

Ao fazer um estudo detalhado sobre o Componente Contextual na perspectiva da GDF, Connolly (2007) diz que, de maneira geral, contexto é tudo aquilo que rodeia o discurso e que é relevante para sua produção e interpretação. Assim, o contexto é dinâmico, pois vai mudando à medida que o discurso vai avançando e se modificando também. De acordo com o autor, há quatro distinções básicas que devem ser consideradas para definir o conceito de contexto: a) contexto discursivo x contexto situacional; b) contexto físico x contexto sociocultural; c) contexto estrito $x$ contexto amplo; d) contexto mental $x$ contexto extramental ${ }^{32}$.

O contexto situacional pode ser subdividido em contexto físico, isto é, o universo material, que integra fatores como tempo e espaço, o que Hymes (1972, apud CONNOLY, 2007) chama de setting [cenário]; e contexto sociocultural, que abrange fenômenos não-concretos como organização social e padrões de pensamentos e comportamentos (aqui, considera-se, por exemplo, os participantes do discurso, suas características psicossociais, o propósito da interação, etc.) e que Hymes (op.cit) chama de scene [cena].

O contexto discursivo, por sua vez, ainda segundo Connolly (2007), é o discurso multimodal circundante, incluindo tanto aspectos linguísticos como não linguísticos.

32 No original: (a) Discoursal context versus situational context. (b) Physical context versus socio-cultural context. (c) Narrower context versus broader context. (d) Mental context versus extra-mental context (CONNOLLY, 2007, p. 14). 
Tanto o contexto situacional como o discursivo podem ser subdivididos em estritos ou amplos. Quando restritos, referem-se ao co-texto, ou seja, ao contexto textual circundante, ao fragmento a ser analisado ou entendido. Já quando amplos, referem-se ao intertexto, que são as referências ou alusões a outros textos.

Segundo Connolly (2007), ainda é preciso considerar os gêneros discursivos, já que determinados enunciados seriam aceitáveis em uns e estranhos em outros. $O$ autor cita como exemplo o enunciado $O$ esquilo repreendeu o coelho, que seria aceitável em um conto de fadas, por exemplo, mas estranho em um artigo científico. Aqui, também se faz distinção entre gêneros orais e escritos.

Por último, a distinção entre contexto mental e contexto extramental refere-se ao que está na mente dos participantes ou no mundo. Os diversos pontos de vista particulares que os participantes têm sobre algo constituem o contexto mental, formado por memórias, inferências, crenças, etc. O autor ressalta que:

[...] o contexto mental é uma consideração extremamente importante, porque a única maneira em que fatores contextuais podem afetar diretamente a produção e interpretação do discurso é através de sua presença na mente desses indivíduos (CONNOLLY, 2007, p. 19)33.

Aplicando essas concepções ao modelo da GDF, Connolly (2007) sugere que o termo Componente de Saída (Output), que mostramos na figura 1 (layout geral da GDF), seja atualizado e modificado para o termo Componente Empírico (Empiric Component), emprestado dos estudos semióticos. Essa mudança se justificaria pela atual importância que o modelo teórico dá à produção e ao produtor dos enunciados, enquanto a nova proposta seria mais neutra e equilibrada entre produção e recepção (produtor e receptor). Além disso, o Componente Contextual, representado também na figura 1, deveria prever todos os tipos de contextos, abarcados sob um Supercontexto. Assim, Connolly (2007) propõe a seguinte atualização do quadro geral da teoria:

33 Tradução nossa do original: [...] mental context is an extremely important consideration, because the only way in which contextual factors may directly affect the production and interpretation of discourse is through their presence in the mind of those individuals. 


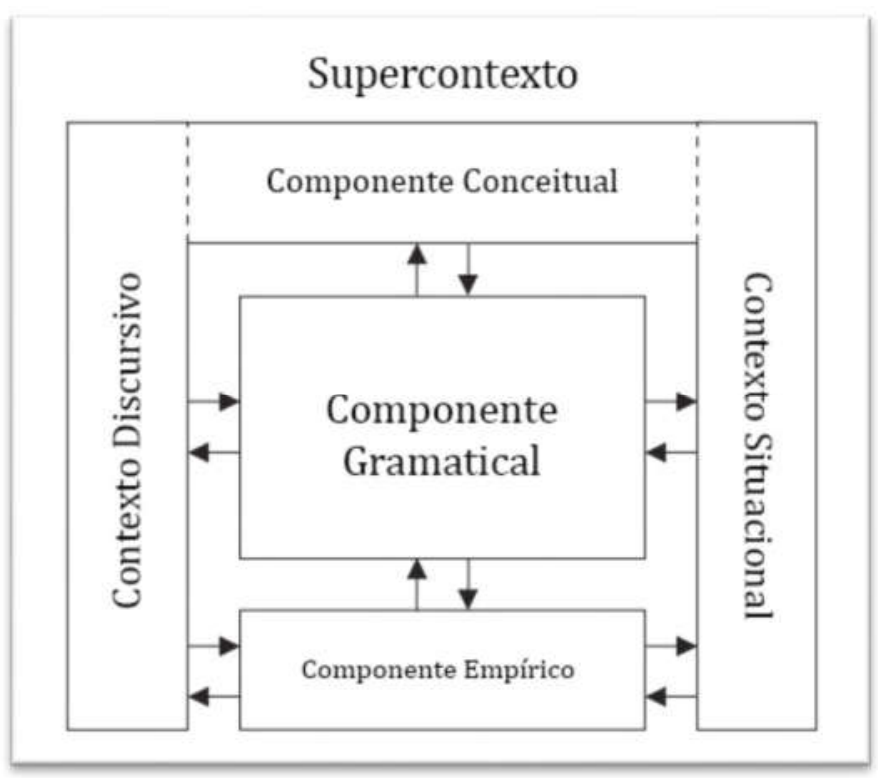

Figura 11 - Esboço modificado do layout geral da GDF

(Adaptado de CONNOLLY, 2007, p. 21)

Assumimos, assim como argumentado por Connolly (2007), que a ordenação dos constituintes (ou ordem das Palavras) é altamente dependente do contexto, e é a partir desse pressuposto que o presente trabalho é construído.

Todas essas ideias de Connolly (op. cit.) entram em conjunção com as ideias de Cornish (2008, apud PEZATTI, 2010), para quem:

[...] contexto é o domínio de referência, que envolve o co-texto, o gênero do evento de fala, o discurso já previamente construído, a situação específica de enunciação de um dado texto e o ambiente sociocultural pressuposto, que inclui o conhecimento pessoal mútuo bem como conhecimento enciclopédico e cultural. É por evocar um contexto apropriado que o destinatário (ou leitor) pode criar discursos com base em sequências conectadas de pistas textuais que é o texto (PEZATTI, 2010, p. 6) ${ }^{34}$.

O Discurso, por sua vez, é o produto mentalmente representado de sequências de enunciados e de atos proposicionais e ilocucionários, sempre carregados de alguma intenção comunicativa (e de interpretações provisórias dessas intenções) e integrados em um dado contexto.

${ }^{34}$ Esclarecemos que, neste fragmento, Pezatti (2010) faz uma paráfrase das ideias de Cornish (2008) e nós citamos a autora, pois não tivemos acesso ao texto original do autor. 
Do ponto de vista do falante, o discurso é criado tanto em termos de suas intenções comunicativas quanto em função do feedback do texto produzido para compreender essas intenções dadas pelas reações do destinatário. Já do ponto de vista do destinatário, o discurso é construído por meio dos inputs provenientes do texto e do contexto, mas as textualizações do destinatário em reação às do falante naturalmente farão emergir um novo discurso via negociação com o falante. Assim o discurso claramente depende tanto do texto quanto do contexto. Texto, contexto e discurso, segundo Cornish (2008: 100), são interdependentes, interativos e interdefinidores (PEZATTI, 2010, p. 6)

A referência anafórica é o fenômeno diretamente relacionado ao Componente Conceitual previsto pela GDF. Esse assunto será retomado no capítulo 4, quando falarmos dos casos de duplicações e de anáforas em PB e em EP.

Seguindo a apresentação do layout geral da GDF, temos o Componente Gramatical, onde as representações conceituais advindas do Componente Conceitual são traduzidas pela Formulação em representações pragmáticas (no Nível Interpessoal) e em representações semânticas, no Nível Representacional. Para a GDF essas representações não são universais e por isso podem ser diferentes em cada língua, mesmo que as representações conceituais sejam semelhantes. Elas recebem codificações nos Níveis Morfossintático e Fonológico, para alcançar o estatuto de um enunciado completo e adequado, quando enviadas para o Componente de Saída, que por fim gera as expressões acústicas ou escritas que efetivamente serão usadas na comunicação.

A GDF só leva em consideração alguma dessas camadas se ela for relevante na língua analisada, ou seja, quando servir para explicar alguma questão estrutural da gramática dessa língua. Não há, portanto, um estatuto universal para todas as camadas.

Voltando ao quadro geral da GDF (figura 10), apresentado acima, as elipses representam as operações de Formulação e de Codificação; os quadrados, os primitivos usados nas operações; e os retângulos, os níveis de representação produzidos pelas operações. Além disso, a organização que a GDF dá ao Componente Gramatical demonstra um dos pressupostos dessa teoria: o de que a pragmática comanda a semântica e juntas, por sua vez, comandam a morfossintaxe, que comanda a fonologia, como mostramos no esquema seguinte: 


\section{Pragmática $>$ Semântica $>$ Morfossintaxe $>$ Fonologia}

Esquema 1 - - Hierarquia dos níveis do Componente Gramatical

Como vemos no esquema acima, o Componente Gramatical é composto por quatro níveis: o Interpessoal, o Representacional, o Morfossintático e o Fonológico, todos representados na figura por um retângulo. Cada um desses níveis é estruturado hierarquicamente em várias camadas, além de, para cada uma delas, estarem previstos um elemento nuclear, a incidência de operadores e de modificadores, e a presença de funções ${ }^{35}$. Como neste trabalho abordaremos conceitos que podem se confundir com a categoria pragmática Ênfase, os únicos tipos de operadores dos quais falaremos são os que funcionam para a marcação dessa categoria, por isso definimos esse conceito aqui, para depois retomá-lo em outros momentos.

Os operadores são elementos gramaticais que se aplicam a unidades de seu respectivo nível, indicando uma categoria gramatical (gênero, número, aspecto, tempo, modo, definitude, modalidade, entre outras). Conforme Hengeveld \& Mackenzie (2008), um operador corresponde a uma marcação morfossintática, prototipicamente uma flexão ou um contorno entonacional. Os operadores prototípicos não podem ser modificados e, caso sejam Palavras, são invariáveis e potencialmente passíveis de redução fonológica. No entanto, segundo Souza (2017), estudos no campo da Teoria da Gramaticalização têm problematizado esses limites e alguns autores, como Keizer (2007, apud SOUZA, 2017), já propuseram uma nova categoria que representaria esse interstício entre modificador e operador: são os operadores lexicais.

Apresentaremos, no subitem a seguir, os quatro níveis de organização do Componente Gramatical, representados na Figura 1 pelos retângulos, como já dito: o Interpessoal, o Representacional, o Morfossintático e o Fonológico.

\footnotetext{
${ }^{35}$ Não explicaremos os modificadores de nenhuma das camadas, visto que os excluímos de nossas análises, por não serem constituintes configuracionais. Quanto aos operadores, nos restringiremos aos que servem para marcação de Ênfase, como veremos no capítulo 4. As funções também serão explicadas detalhadamente nos capítulos 4 e 5.
} 


\subsection{Níveis do Componente Gramatical}

\subsubsection{Nível Interpessoal (NI)}

O Nível Interpessoal (NI) "[...] capta todas as distinções que dizem respeito à interação entre o falante e o Ouvinte" (HENGEVELD \& MACKENZIE, 2012, p. 51). Em outras palavras, representa as ações linguísticas do Falante para alcançar seu objetivo comunicativo, e seu sequenciamento reflete a ordem das estratégias utilizadas. Nas camadas mais altas, refere-se às escolhas retóricas de toda a estruturação do discurso e, nas camadas mais baixas, refere-se a distinções pragmáticas e gramaticalmente relevantes que demonstram como o Falante molda suas mensagens considerando o que ele espera sobre o conhecimento e os sentimentos do Ouvinte.

$\mathrm{Na}$ sequência, apresentamos cada uma das camadas que compõem o NI.

\subsubsection{Movimento}

O Movimento ou Move (M) é a camada mais alta do Nível Interpessoal e abriga o segmento inteiro de discurso que é considerado relevante no processo de interação. Sua complexidade pode variar enormemente, do silêncio até um longo trecho de discurso.

É uma categoria de difícil definição, mesmo para Hengeveld \& Mackenzie, que recorrem a uma definição dada por Hannay \& Kroon (2005 apud HENVEGELD \& MACKENZIE, 2008, ps ${ }^{36}$. 212-214) para tentar explicá-la: "[...] o Movimento é a unidade livre mínima de discurso que é capaz de entrar em uma estrutura de troca $[\ldots]^{37}$. Essa estrutura de troca a que se referem os autores pode ser entendida pelo fato de o Movimento ser a requisição de uma resposta ou ser ele mesmo uma resposta, ou seja, uma reação ao pedido feito pelo Falante (podendo ser, inclusive uma objeção). Nos textos conversacionais, essa categoria aparece mais claramente,

${ }^{36}$ Quase todas as citações e exemplos que citamos de Hengeveld \& Mackenzie (2008) ao longo de todo o trabalho são da versão eletrônica do livro (e-Book) e por isso usamos a abreviação ps para nos referimos às posições e não às páginas, tal como aparece nesta versão.

${ }^{37}$ Tradução nossa do original: [...] the minimal free unit of discourse that is able to enter into an exchange structure [...]. 
pois está delimitada prosodicamente. Sendo assim, há dois tipos de Movimentos: o de Iniciação (sendo o Movimento provocador) e o de Reação.

O Movimento está constituído por um ou mais Atos Discursivos (A). O núcleo do $M$ é, portanto, um ou mais (A); pelos Atos Discursivos (A), entendidos como a menor unidade linguística comunicativa, como veremos na sequência.

\subsubsection{Os Atos Discursivos}

Delimitar um Ato Discursivo, bem como o Movimento, nem sempre é uma tarefa simples. Os próprios Hengeveld \& Mackenzie (2008, ps. 364) dizem que não há uma correspondência única entre o Ato Discursivo e alguma unidade linguística, pois um Ato Discursivo pode ser expresso por Orações, Palavras ou Sintagmas, já que muitas vezes, para que o Falante atinja sua intenção comunicativa, não é necessário que haja uma estrutura oracional.

Os autores (ibidem, 2008, ps. 214) definem de maneira vaga essa categoria, como "[...] a menor unidade identificável do comportamento comunicativo" ${ }^{38}$. As únicas características que os autores apontam como índices definidores do Ato Discursivo são: (1) segmentos de mesma força ilocucionária tendem a formar um único Ato Discursivo e (2) Contornos Entonacionais distintos no Nível Fonológico marcam Atos Discursivos diferentes, mesmo quando constituídos por mesma força ilocucionária. $O$ A, portanto, corresponde a uma unidade de entonação, organizada sobre um esquema ilocucionário, que envolve ao menos dois participantes do discurso: o Falante $(S)^{39}$ e o Destinatário (D), além do Conteúdo Comunicado (C).

Estabelecer o Ato Discursivo como a unidade mínima de análise, como explicamos anteriormente, permite-nos considerar tanto elementos menores que a Oração, quanto elementos extraoracionais, que eram vistos à margem da gramática (como por exemplo, os marcadores discursivos e, no caso específico desta tese, os constituintes que ocupam posições anteriores ou posteriores à Oração, mas que fazem parte da Expressão Linguística, como os que desempenham as funções retóricas de Orientação e Esclarecimento, como explicaremos no capítulo 5).

\footnotetext{
38 Tradução nossa do original: [...] a Discourse Act as 'the smallest identifiable unit of communicative behaviour'.

${ }^{39}$ Mantém-se a sigla (S) usada no inglês, para referir-se a speaker.
} 
O exemplo seguinte, tomado de Lopes (2010), ilustra o que são os Atos Discursivos:

(1) Intensa, irreverente, contraditória, autodestrutiva, mas antes de tudo uma grande cantora. Assim era Maysa (1936-1977), nossa eterna diva da fossa e da dor de cotovelo, cuja história pessoal e, naturalmente, sua música, inspiraram a minissérie da Globo. [...]

Crítica 46 -"Maysa é a nossa versão de Amy Winehouse" Folha de São Paulo, 11/01/09

Segundo Lopes (2010, p. 62), "[...] acima, tem-se um Move (M) de descrição, constituído de apenas um Ato Discursivo (A), cuja unidade é mantida pela identidade na força ilocucionária (de valor DECLarativo) entre as predicações".

Abaixo, temos um exemplo de motivação fonológica, criado por nós, com base no exemplo dado por Hengeveld \& Mackenzie (2008, ps. 864-867).

(2) A: O que aconteceu ontem no campeonato?

B: Real Madrid ganhou. E o Grêmio perdeu.

No exemplo, o Movimento de iniciação do Falante A provoca o Movimento de reação de B. O Movimento de B está composto por dois Atos Discursivos, como podemos ver pelo contorno entonacional. O sinal de pontuação que separa os dois períodos de B é importante discursivamente, já que dizer Real Madrid ganhou e o Grêmio perdeu não é a mesma coisa que dizer como B disse. No primeiro caso o Falante quer apenas informar o resultado do campeonato, ao passo que, quando recorre à opção de usar dois períodos mais curtos de entonação mais marcada (representada pelo ponto entre eles), subentende-se o desejo do Falante de enfatizar a informação do segundo predicado.

Há três tipos de Atos Discursivos: (1) Expressivos; (2) Interativos; e (3) llocutivos. Os primeiros expressam os sentimentos do Falante, como, por exemplo, em Credo! Os Interativos são expressões fixas, invariáveis e frequentemente ritualizadas, como em Parabéns! Já os llocutivos envolvem um Conteúdo Comunicado e uma llocução lexical ou abstrata como em Eu vou ler isso.

Se voltarmos ao exemplo de Tem um cachorro enorme nesta casa!, cujo Conteúdo Composicional é a intenção de alerta, como dissemos anteriormente, a estratégia usada pelo Falante para alcançar essa intenção é o uso de uma llocução declarativa com um operador de ênfase no Nível Interpessoal (representado 
graficamente pelo ponto de exclamação), já que em português não há uma força ilocucionária específica para alertas. Essa estratégia se situa no Nível Interpessoal.

Além disso, o Ato Discursivo também pode conter operadores e modificadores. Os operadores, no nível do Ato Discursivo, servem para, por exemplo, marcar ironia, ênfase ou mitigação. Como explicamos anteriormente, nos interessa, neste trabalho, abordar alguns operadores de Ênfase. No nível do Ato Discursivo, por exemplo, a própria entonação da frase pode funcionar como operador de Ênfase. Algumas partículas (constituintes gramaticais) também podem desempenhar essa função, como ocorre no espanhol, quando se usa Que em llocuções Exclamativas em que o Que não é, no entanto, um pronome exclamativo, razão pela qual não é acentuado. Vemos isso no exemplo:

(3) ¡Que no me gusta nada esa película! (HENGEVELD \& MACKENZIE, 2008, ps. 1040). [ $\varnothing \quad$ Não gosto nada desse filme!]

De acordo com Hengeveld \& Mackenzie (2008), a relação entre Atos Discursivos pode ser de dependência ou de equipolência (em que não há uma relação hierárquica entre eles). As relações dependentes são representadas como uma função retórica do Ato Discursivo dependente, que pode ser de Motivação, Concessão, Orientação e Correção (ou Esclarecimento). Selecionamos, assim, duas funções retóricas para análise (portanto, só de Atos Discursivos dependentes, excluindo de nossa análise os Atos cujas relações são de equipolência): a Orientação e o Esclarecimento. Trazemos aqui apenas um exemplo para, de alguma maneira, ir antecipando o que veremos com mais detalhes no capítulo 4:

(4) ${ }^{*} B R U$ : mas a sua bolsinha é linda hhh // gente / o Tommaso / durante o negócio / ele tava vendo jogo de futebol na internet / cê acredita // (C-ORAL-BRASIL-bfamcv22)

No exemplo (4), o constituinte o Tommaso constitui um Ato Discursivo dependente do outro Ato Discursivo ele tava vendo jogo de futebol na internet, servindo como uma espécie de ancoramento do que se dirá depois, ou seja, servindo para indicar ao Destinatário a intenção do Falante de introduzir um referente no discurso. Como se quisesse mostrar ao seu Ouvinte: Olha, é disso que vou falar: do Tommaso. Esse constituinte é extraoracional e tem a função retórica de 
Esclarecimento. Mas, como já dissemos, esse assunto será retomado com mais detalhes no capítulo 4.

\subsubsection{A llocução}

Os Atos Discursivos têm suas propriedades formais e lexicais capturadas pelas llocuções, apesar de não haver uma relação direta entre uma intenção comunicativa específica e uma llocução. A llocução pode ser entendida como a tentativa de o Falante produzir certo efeito e implica certa modificação da situação interlocutiva.

Vejamos a definição de llocução, dada por Hengeveld \& Mackenzie (2008, ps. 1057-1060) $)^{40}$ :

A llocução de um Ato Discursivo captura as propriedades lexicais e formais desse Ato Discurso que podem ser atribuídas ao seu uso interpessoal convencionado para alcançar uma intenção comunicativa. As intenções comunicativas incluem Atos Discursivos tais como chamar atenção, afirmar, ordenar, questionar, advertir, solicitar, etc., que podem ser expressos em llocuções como Vocativa, Declarativa, Imperativa, etc. Não há uma relação unívoca (de um para um) entre uma intenção comunicativa específica e uma llocução, pois as línguas podem usar diferentes meios linguísticos para expressar diferentes intenções comunicativas.

Hengeveld \& Mackenzie (2008, ps. 1079) elencam um total de doze categorias de llocução, mas cada língua pode dispor de apenas algumas dessas categorias. Para este trabalho, selecionamos Atos Discursivos com basicamente dois tipos de llocuções, embora essa delimitação não seja rígida: as Declarativas e as Interrogativas. Enquanto nas Ilocuções Declarativas o Falante informa ao Interlocutor sobre o Conteúdo Proposicional evocado por um Conteúdo Comunicado, nas Ilocuções Interrogativas, o Falante requer uma resposta do Interlocutor sobre o Conteúdo Proposicional evocado pelo Conteúdo Comunicado. As Ilocuções

40 Tradução nossa do original: The Illocution of a Discourse Act captures the lexical and formal properties of that Discourse Act that can be attributed to its conventionalized interpersonal use in achieving a communicative intention. Communicative intentions include such Discourse Act types as calling for attention, asserting, ordering, ing, questioning, warning, requesting, etc., which may map onto Illocutions such as Vocative, Declarative, Imperative, etc. There is no one-to-one relation between a specific communicative intention and an Illocution, as languages may differ significantly in the extent to which they make use of linguistic means to differentiate between communicative intentions. 
Interrogativas são ainda subdivididas em dois tipos (as Polares e as de Conteúdo), para os quais dedicamos o capítulo 6 .

Além das categorias citadas, Hengeveld \& Mackenzie (2008) apontam que uma llocução também pode ser representada por vocativos e por interjeições e expressões que manifestem as reações do Falante em relação à situação discursiva (e que constituem Atos Discursivos independentes).

\subsubsection{O Conteúdo Comunicado (C)}

O Conteúdo Comunicado (C) representa a totalidade do que o Falante pretende comunicar ao seu Ouvinte. Vejamos os exemplos (5a) e (5b): 41

(5a) Rebeca traz a bolinha.

(5b) Rebeca, traz a bolinha!

No primeiro caso, há C porque o Falante enuncia uma asserção, um Ato Discursivo de llocução Declarativa. No segundo, há $\mathrm{C}$, pois se trata de uma ordem, isto é, um Ato Discursivo de llocução Imperativa.

Cada Conteúdo Comunicado contém pelo menos um Subato, que será explicado a seguir.

\subsubsection{Os Subatos}

Como o próprio nome já sugere, o Subato é hierarquicamente subordinado ao Ato Discursivo. Os Subatos podem ser de atribuição (T), quando o objetivo do Falante é evocar uma propriedade, e de referência $(R)$, quando se evoca um referente. Hengeveld \& Mackenzie (2008, ps. 1284), exemplificam que se um Falante diz: Está chovendo, ele apenas está descrevendo algo, sem evocar nenhum referente. Por isso, essa fala é um Subato de atribuição. Se o Falante evoca algum referente, como em $A$ chuva está muito forte (em que o termo $A$ chuva é o referente), então temos um Subato Referencial. Para nossa pesquisa, selecionamos apenas Subatos de referência, e as razões dessa seleção serão explicadas no capítulo 4.

\footnotetext{
${ }^{41}$ Exemplos criados por nós.
} 
Subatos são pragmaticamente funcionais, servindo de Moldes de Conteúdo. Chegamos, portanto, a um nível bastante importante para nosso trabalho. É justamente neste nível, o dos Subatos, que se centrará praticamente toda nossa pesquisa.

A hierarquia de todas as unidades discursivas (camadas) relevantes para o Nível Interpessoal apresentadas no subitem 2.1.1 pode ser expressa resumidamente por meio do seguinte esquema:

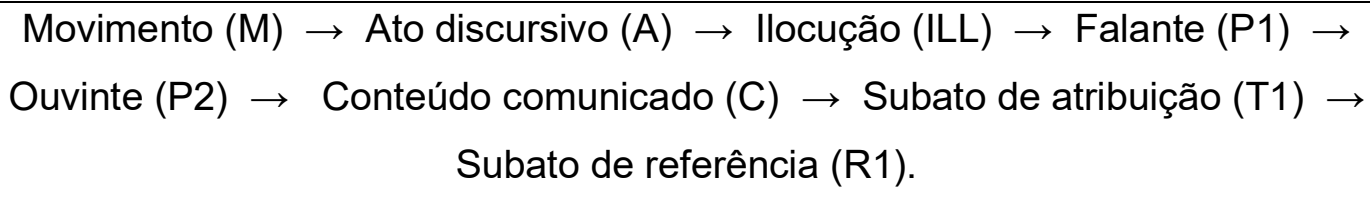

Esquema 2 - Camadas do Nível Interpessoal

Passemos, então, às explicações sobre o segundo nível do Componente Gramatical: o Representacional.

\subsubsection{Nível Representacional (NR)}

É no Nível Representacional (doravante NR) que se estabelece a relação de uma unidade linguística com o mundo real ou imaginário que ela descreve. Por isso, também pode ser chamado de Nível Semântico, pois "[...] se ocupa da manifestação de conteúdos que estejam ligados à experiência que o Falante possui do mundo concreto, real ou de seu universo subjetivo, interior" (LOPES; 2010, p. 71). Por descrever esses mundos, o NR refere-se à designação e não à evocação (como ocorre no Nível Interpessoal).

Da mesma maneira como ocorre no $\mathrm{NI}$, O NR lida com três primitivos: esquemas, lexemas e operadores primários. Devido ao escopo deste trabalho, nos limitaremos a abordar os esquemas, que revelam a existência de recursos gramaticais em cada língua para que se possam distinguir categorias semânticas, como as de designação (animado/inanimado), as funções semânticas (Ator, Inativo e Locativo) e as oposições de número (singular, plural). Por se tratar de um tema central à nossa pesquisa, dedicamos um subitem exclusivamente para abordar as funções semânticas previstas na GDF, mas preferimos apresentá-lo no final deste item (2.1.2), 
quando já tivermos apresentado todas as suas camadas, pois, para explicar as funções semânticas, nos valeremos da designação de Estados-de-coisas, que ainda será explicado.

O NR também é constituído por camadas. O item que ocupa a posição mais alta do nível Representacional é o Conteúdo Proposicional ( $p$ ), que explicaremos na sequência, seguido das demais camadas.

\subsubsection{O Conteúdo Proposicional}

O Conteúdo Proposicional $(p)$ é um construto mental que representa as crenças e os desejos do Falante. Como construto mental, não pode ser localizado espaço-temporalmente, mas, segundo Hengeveld \& Mackenzie (2012), pode ser avaliado em termos de sua verdade e qualificado em termos de atitudes proposicionais (certeza, dúvida, etc.) e/ou em termos de sua origem ou fonte (conhecimento partilhado, evidência sensorial, inferência).

Os Conteúdos Proposicionais, segundo Hengeveld \& Mackenzie (2008, ps. 1927) dividem-se em factuais, quando estão relacionados ao conhecimento ou uma crença sobre o mundo real, e em não-factuais, quando são desejos ou expectativas com relação a um mundo imaginário. Enquanto o Conteúdo Comunicado (C) é sempre atribuído ao Falante, o Conteúdo Proposicional (p) pode ser atribuído ao Falante ou também a outras pessoas como em (6):

(6) Marcos foi viajar porque talvez tivesse que atender clientes.

Nesse exemplo, o (p) é a parte destacada, encaixada, atribuída ao termo Marcos e que expressa uma atitude proposicional por meio do uso de talvez.

O Conteúdo Proposicional contém um ou mais Episódios (ep), que será o próximo item a ser explicado.

\subsubsection{O Episódio}

Episódio pode ser entendido como as partes coerentes de um discurso narrativo. Segundo Hengeveld \& Mackenzie (2008, ps. 1809), Episódio corresponde a uma série de Estados-de-Coisas tematicamente coerentes, com unidades de tempo, 
espaço e indivíduos. O Episódio (ep), como vemos, contém um ou mais Estados-deCoisas (e), dos quais nos ocuparemos no próximo subitem.

\subsubsection{Estado-de-Coisas ${ }^{42}$ (ou Eventos)}

Os Estados-de-Coisas (doravante EsCos) indicam eventos ou estados que podem ou não acontecer/ocorrer em qualquer intervalo de tempo, e podem ser localizados no tempo relativo e avaliados em termos de sua realidade. A diferença entre as categorias de Episódio e Evento, segundo Hengeveld \& Mackenzie (2012), é que a primeira admite modificadores de tempo absoluto (hoje, semana que vem, anteontem, etc.), enquanto o Evento admite apenas modificadores de tempo relativo (antes da viagem, em uma hora, no período da tarde, etc.).

Como exemplo, podemos considerar as desinências verbais dos verbos finitos, conforme nos mostram Hengeveld \& Mackenzie:

(7) Ao sair, parando para verificar a caixa de correio, dando uma olhada para a calçada e parando para ajustar o seu chapéu, ele caminhou até seu carro (HENGEVELD \& MACKENZIE, 2012, p. 56).

Os autores explicam que, nesse exemplo, o Episódio é descrito por uma série concatenada de formas verbais narrativas não finitas (sair, verificar, dando, parando, ajustar) e pela forma final finita (caminhou). Como se vê, o Episódio é localizado em tempo absoluto (passado, no nosso exemplo, representado pelo verbo finito), enquanto os EsCos são localizados em tempo relativo (no nosso exemplo, constituído por toda a descrição, anterior ao ele caminhou até seu carro). Assim, temos vários Estados-de-coisas para um Episódio.

O exemplo (8) mostra também que é possível combinar um Episódio (cujo tempo absoluto é exemplificado pela expressão ela tava viva ainda) com EsCos (cujo tempo é relativo é exemplificado pela expressão antes de chegar):

(8) *MAR: <mas diz> + <uai / mas diz que> [/2] diz que \&e [/2] que ela [/1] levaram ela prum hospital / que ela no [/1] antes de [/2] antes de chegar / ela [/1] ela tava viva ainda // <como é que é isso> // (C-ORAL-BRASIL-bfamcv15).

42 Nos textos que consultamos, há divergências quanto à forma de grafar o termo Estado de Coisas, que ora é grafado com hífen, ora sem hífen, ora com iniciais maiúsculas, ora com minúsculas. Nós adotamos a grafia Estado-de-Coisas, tomando por base a grafia usada por Hengeveld \& Mackenzie (2008): State-of-Affairs. 
O que é mais relevante em nossas análises, é diferenciar EsCos e Episódios dinâmicos de EsCos e Episódios não dinâmicos. Os dinâmicos designam uma mudança de estado, com um input de energia (algo acontece) e correspondem ao que tradicionalmente se chama de predicado verbal. Já nos não dinâmicos não há mudança de estado (nada acontece, nada se transforma) e são formados, por exemplo, com uma predicação adjetiva e, principalmente, marcados pela ausência de um constituinte com função semântica Ator e pela presença de um Inativo. Corresponde ao que a tradição gramatical denomina predicado nominal.

EsCos são, em última instância, constituídos pelo que na GDF se designa Propriedade Configuracional. A Propriedade Configuracional corresponde ao predicado e seus argumentos, e é formada por categorias semânticas equivalentes, ou seja, que não mantêm relação hierárquica entre si, sobre as quais tratará o próximo subitem.

\subsubsection{Propriedade Configuracional}

Destacamos que essa definição é bastante importante para nosso trabalho, uma vez que selecionamos apenas constituintes Configuracionais para nossas análises.

Propriedades são entidades de ordem zero, o que significa "[...] que não podem ser caracterizadas por parâmetros de espaço e tempo e não têm existência independente" (LOPES, 2010, p. 77). Portanto, as Propriedades Configuracionais "[...] representam o inventário dos esquemas de predicação relevantes para uma língua, prevendo questões de valência, função semântica e grau de definitude dos argumentos, etc." (LOPES; 2010, p. 77-78)43. Em outras palavras, a Propriedade Configuracional refere-se ao conjunto formado pelo predicado, que pode ser verbal, nominal, adjetival ou adverbial, e seus argumentos, com funções sintáticas e semânticas.

43 Segundo Hengeveld \& Mackenzie, Configurational Properties constitute the inventory of predication frames relevant to a language, and non-Configurational Property layers host the lexemes of a language. (HENGEVELD \& MACKENZIE, 2008, ps. 2331) 
Aqui, consideram-se, por exemplo, o que a na tradição gramatical chama-se de verbos intransitivos ou transitivos (e seus requeridos argumentos). Tanto em PB como em EP, há os seguintes tipos de Propriedades Configuracionais: de predicaçãozero, de propriedades Configuracionais de predicados de um, de dois e de três lugares, como mostramos a seguir.

- Propriedades configuracionais de predicação de zero lugar

Nas propriedades de predicação-zero (zero-place predication) se incluem as construções existenciais. Como exemplos, podemos citar as construções com verbos impessoais que designam fenômenos da natureza, como chover e nevar (no PB) e llover e nevar (em E), como vemos nos exemplos de (9) e (10):

(9) Várias vezes que a gente tava aqui, fez esse tempo e choveu lá noutro lugar, né (CORAL-BRASIL-bfamdl03).

Casi nunca llueve en el desierto de Atacama (exemplo criado por nós).

[Quase nunca chove no deserto do Atacama]

Integram também esse grupo as construções existenciais (ou apresentativas), formadas com os verbos ter e haver (em PB), como em (11), (12) e haber (em E) ${ }^{44}$, como em (13):

Tem o Sesc que é bom pra caramba (C-ORAL-BRASIL-bfamcv01).

Há muitas pessoas aqui (exemplo criado por nós).

Hay miles de millones de gente (C-ORAL-ROM-efamcr02).

[Há milhares de pessoas]

A análise deste tipo de construção não está prevista em nosso trabalho, já que não gera questões referentes à ordenação de constituintes Configuracionais ${ }^{45}$.

\footnotetext{
44 Ao contrário do que ocorre no PB, em E, o verbo tener (ter) não pode indicar existência.

45 Segundo Pezatti (2012, p. 373): "Esse tipo de predicação contém somente uma unidade semântica, que não é argumento de nenhum predicado. Para marcar o tempo, é então introduzida uma cópula vazia como haver, ter ou ser [...]".
} 
- Propriedades configuracionais de predicação de um lugar

Nas Propriedades de um lugar (One-place Property), o Predicado seleciona apenas um argumento. Correspondem às estruturas com verbos que a tradição gramatical ou teorias outras que não a GDF designam de intransitivos ou monoargumentais. Como exemplos, podemos citar as construções com verbos do tipo acontecer, acordar, morrer (no PB), como em (14) e (15) ou acontecer/suceder/pasar, despertar(se) e morir(se) (no E), como em (16) e (17):

${ }^{*} B R U$ : o cara vai fazer um documentário / num / deserto / ${ }^{*} P R I$ : hum hum //

*BRU: / sobre uma família de camelos // e aí acontece uma coisa interessante // <que / uma das> camelas / ela pare o filhote / só que ela rejeita o filhote // (C-ORAL-BRASILbfamcv22).

(15) *JUN: <a minha mãe falou assim / não> / mas \&he / \&he / isso ${ }^{46}$ acontece / a gente tá sujeito // (C-ORAL-BRASIL-bfamcv15)

(16) $\quad$ *PIE: $[<]<$ <es que> el Figo parece que se [///] ya es / ya / el no va más //\$ eso ya es / $<q u e>\ldots \$$

${ }^{*} P A Z:[<]<e s$ que / eso es muy> fuerte / tía //\$

${ }^{*} P I E:<e n$ el> $[/ \$$

${ }^{*} P A Z:[<]<$ no / pero que $>$ siempre pasa eso $/ / \$<$ cuando $>+\$$

${ }^{*} \mathrm{PIE}:[<]<$ en el Madrid> / como si no hubiese otro jugador nada más que Figo //\$ (CORAL-ROM-efamdl33).

[Sempre acontece isso] ${ }^{47}$

(17) $\quad$ *ANA: $[<]<$ pero eso $0^{48}>$ pasa siempre $/ / \$$ siempre está la posibilidad de conocer a alguien ... \$ (C-ORAL-ROM-efamcv10)

[mas isso acontece sempre].

Constatamos, nos exemplos de (14) a (17), que a ordem dos constituintes nas Propriedades configuracionais de predicado de um lugar ocorre de maneira semelhante em PB e em E, podendo o único argumento do verbo aparecer à esquerda

46 O constituinte isso refere-se ao assassinato do filho da Falante.

${ }^{47}$ Por razões práticas, preferimos traduzir, neste em outros exemplos em $\mathrm{E}$, somente o fragmento que nos interessa para a análise.

${ }^{48} \mathrm{O}$ constituinte eso refere-se a não ser correspondido nas relações amorosas. 
ou à direita do Predicado. Essa é uma característica importante que retomaremos no capítulo 4, ao falarmos sobre as funções pragmáticas, e por isso, oportunamente retomaremos os exemplos dados aqui, bem como os demais exemplos desta seção.

Neste grupo também podem ser expressas as construções de identificação, mas essas últimas não compõem nossos objetos de análise ${ }^{49}$.

- Propriedades configuracionais de predicação de dois lugares

Nas Propriedades de dois lugares (two-place Property), o Predicado seleciona dois argumentos. Correspondem às estruturas com verbos que a tradição gramatical ou teorias outras que não a GDF designam de transitivos diretos (no PB). Como exemplos, podemos citar as construções com verbos do tipo entender e traduzir (no PB), como em (18) e (19) e hacer [fazer] e tener [ter] (no E), como em (20) e (21):

(19) *PAU: [231] cê entendeu direitinho / <o desenho> dele?

${ }^{*} R O G$ : [232] <entendi> // [233] é / eu entendi direitinho o desenho que e' fez pra mim / uai // (C-ORAL-Brasil-bpubdl01)

(20) *MAR: aí ela deu uma folha / aí me falaram que era trabalho // aí eu nũ tinha entendido a folha / traduzi a folha toda e nũ entendi o que que era // (C-ORAL-BRASILbpubdl11).

(21) *DOL: vive en Las Rozas / y su teléfono es / noventa y uno / seis / treinta y seis ...\$ ésta ha hecho primaria // \$ (C-ORAL-ROM-epubdI07)

[Esta fez o primário]

${ }^{*} P R I$ : y tiene trabajo allí el chaval / no ?\$

*NAT: hhh //\$ ahora acaba de abrir una [/] una clínica //\$ (C-ORAL-ROM-epubdl06)

[e tem trabalho lá o moço, não?]

[e o moço tem trabalho lá, né?]

Vemos que, nos exemplos dados, o esquema de predicação é o seguinte:

49 Segundo Pezatti (212, p. 376), "Em construções de identificação, as duas unidades semânticas representam modos alternativos de visão da mesma entidade, não havendo, portanto, atribuição de propriedade". Exemplos: "[...] Mauro e Filhos é um time muito legal [...]" (C-ORAL-BRASILbfamcv01) e "[...] es verdad / que el periodista es él [...]" (C-ORAL-ROM-efamdl20). 


\begin{tabular}{|c|c|c|}
\hline Predicado & Argumento $^{\mathbf{5 0}}$ & Argumento B \\
\hline entendi & eu & o desenho que ele fez pra mim \\
\hline entendi & eu (implícito) & a folha \\
\hline traduzi & eu (implícito) & a folha \\
\hline ha hecho & ésta & primaria \\
\hline tiene & el chaval & trabajo \\
\hline
\end{tabular}

Como já dissemos, todos esses exemplos serão retomados mais adiante, ao falarmos sobre as funções semânticas, ainda neste capítulo, e sobre os esquemas de posicionamento e as funções pragmáticas, no capítulo 4.

- Propriedades configuracionais de predicação de três lugares

Nas Propriedades de três lugares (three-place Property), o Predicado seleciona três argumentos. Correspondem às estruturas com verbos que a tradição gramatical ou teorias outras que não a GDF designam de transitivos diretos e indiretos (no PB). Como exemplos, podemos citar as construções com verbos do tipo mandar e dar (para ambas as línguas) e dizer/decir, como vemos nos exemplos seguintes:

*PAU: <mas tem> que saber ler projeto também / né //

${ }^{*} R O G$ : aquele <carinha> do Alexandre lá51 ele me deu o desenho dele //

*PAU: <claro> // (C-ORAL-Brasil-bpubdl01)

(24) *GIL: <no \&ca> + <os times antigos> //a gente nũ vai jogar um e-mail / quem quiser participar participa // a gente vai <mandar / o'> / e-mail pra / tal pessoa / <pra falar $>$ + (CORAL-BRASIL-bfamcv01).

*PAZ: sabes cuánto le daba / diarios / tía / semanales ?\$ *PIE: quién ?\$<Telemadrid> ?\$ *PAZ: [<] <yo xxx> +\$ sí //\$ cien millones // $\$$ le daba Tómbola a Telemadrid / tía

*PIE: ;madre mía! //\$ (C-ORAL-ROM-efamdl33)

[(O)Tómbola dava cem milhões para o Telemadrid, guria/amiga $\left.{ }^{52}\right]$

50 A nomenclatura A e B não indica nenhum tipo de hierarquia entre eles, e a adotamos aqui apenas para evidenciar que se trata de dois argumentos.

51 O constituinte aquele <carinha> do Alexandre lá tem a função retórica de Orientação, que será explicada no capítulo 5.

52 Segundo Jorgesen (2008, p. 388), em seu estudo sobre marcadores discursivos na linguagem juvenil de Madrid, "En el lenguaje juvenil tío/a es usado como marcador vocativo o de control de contacto [...]". 
(26) *PIE: qué suerte //\$ además es que te voy a decir una cosa si / ir a [/] ir / a la televisión / es a ganar dinero //\$ (C-ORAL-ROM-efamdl33)

[te vou dizer uma coisa]

[vou te dizer uma coisa]

O esquema de predicação desses exemplos é resumido no quadro abaixo:

\begin{tabular}{|c|c|c|c|}
\hline PREDICADO & ARGUMENTO A & ARGUMENTO B & ARGUMENTO C \\
\hline deu & ele & o desenho dele & me \\
\hline vai mandar & a gente & o e-mail & pra tal pessoa \\
\hline daba & Tómbola & cien millones & a Telemadrid/le \\
\hline voy a decir & yo (implícito) & una cosa & te \\
\hline
\end{tabular}

Além das Propriedades configuracionais elencadas nesta seção, a GDF também prevê Propriedade Relacional ${ }^{53}$ e Construções de classificação ${ }^{54}$, que, por designarem EsCos não dinâmicos, não fazem porte do escopo de análise desta pesquisa.

Os constituintes argumentais selecionados pelos verbos têm funções semânticas e podem ter funções pragmáticas (Tópico, Foco e Contraste), cujas combinações representam diferentes Moldes de Conteúdo (Categóricos e Téticos). Por isso, o que acabamos de assinalar nesta seção será retomado mais adiante, quando já tivermos explicado essas funções.

As últimas camadas do Nível Representacional (NR) são as Propriedades Lexicais, que não serão abordadas em nosso trabalho, por representarem os constituintes não configuracionais, ou seja, aqueles que não fazem parte do molde de predicação da língua; trata-se, portanto, dos modificadores e operadores de vários

Assim, sugerimos duas opções de traduções para esse termo em PB: guria, vocativo amplamente usado na região sul do Brasil (motivada pela nossa experiência pessoal de vivência nessa região) e amiga, que julgamos menos marcado regionalmente.

53 Construída com um verbo de cópula seguido de um sintagma preposicionado, como em [...] a borracha / é de primeira / tá // borracha látex mesmo // (C-ORAL-BRASIL-bpubdl02) e [...] la carrera es de cinco años //\$ (C-ORAL-ROM - epubdl06).

${ }^{54}$ Formadas por um verbo de cópula seguido de um predicado nominal/adjetival, com função de atribuir uma qualidade ao constituinte com função semântica Inativo (essa função será explicada no capítulo 3, mas, em linhas gerais, corresponderia ao que em outras vertentes teóricas se chama de Paciente), como vemos nos exemplos: [...] esse povo do Galáticos é muito palha [...] (C-ORAL-BRASILbfamcv01) e [...] pero / eso es una buena señal (C-ORAL-ROM-efamdl01). 
tipos, excluindo-se, é claro, o predicado e seus argumentos. Os Indivíduos ( $\mathrm{x}$ ) também não são foco de nosso trabalho, por isso não nos deteremos em explicá-los. Portanto, para resumir o que viemos explicando até aqui, as camadas do Nível Representacional podem ser expressas pelo seguinte esquema:

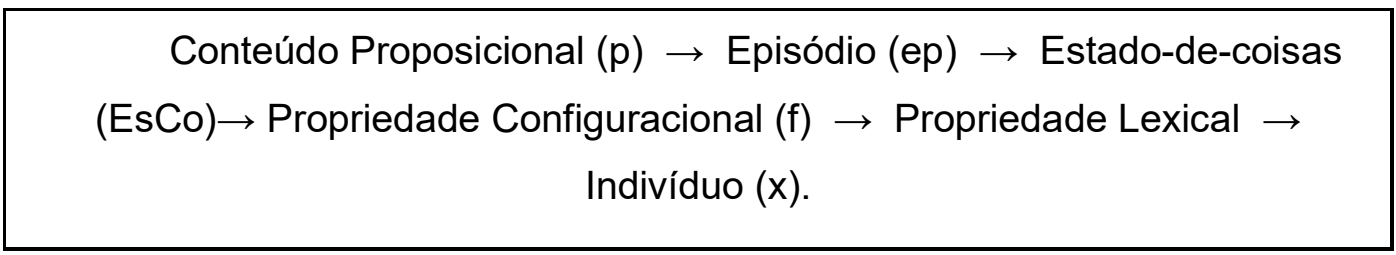

Esquema 3 - Camadas do Nível Representacional

O próximo subitem tratará das funções semânticas do NR, agora que já temos algumas definições que julgávamos pertinentes conhecer previamente.

\subsection{2.a ${ }^{55}$ As funções semânticas na GDF}

Para a GDF, os predicados, por serem elementos nucleares, não apresentam função semântica. No entanto, no Nível Representacional, as funções semânticas e a designação da categoria semântica desempenham um papel muito importante na colocação dos constituintes Configuracionais (argumentos dos predicados), tanto em PB como em EP. Contudo, essas línguas, como veremos, dispõem de mecanismos muitas vezes diferentes para a marcação dessas funções. Segundo Pezatti \& Fontes (2010, p. 180) "As funções semânticas são reflexos gramaticais de consciência cognitiva de que os participantes de um estado-de-coisas desempenham (i) diferentes papéis, (ii) o mesmo papel, ou (iii) nenhum papel no estado-de-coisas".

Hengeveld \& Mackenzie (2008) consideram que as línguas podem dispor de três funções semânticas, universalmente relevantes: Actor, Undergoer e Locative. Alguns autores, tais como Pezatti \& Fontes (2010), propõem as respectivas traduções para essas funções: Ativo, Inativo e Locativo. No entanto, como explicaremos logo mais, o Actor pode corresponder a constituintes com o traço [- volitivo] e, para tentar

\footnotetext{
55 Preferimos não colocar uma numeração hierárquica à 2.1.2 (ou seja, não indicar esse tópico com a numeração 2.1.2.1) porque reservamos essa hierarquia de quarto nível para as camadas deste nível, enquanto a numeração 2.1.3 corresponderá ao terceiro nível do Componente Gramatical, o Morfossintático, que explicaremos mais adiante. Uma solução encontrada foi indicar a nova seção com a letra (a).
} 
evitar possíveis confusões com o que em outras vertentes teóricas se denomina Agente, preferimos propor o termo Ator como tradução para Actor (ao invés de Ativo). Usando os termos em português, nos referiremos a essas funções, respectivamente, pelas siglas $\mathrm{At}^{56}$ (para Ator), I (para Inativo) e L (para Locativo).

Segundo Hengeveld \& Mackenzie (2008), constituintes Atores prototípicos estão envolvidos voluntariamente no EsCo, ou seja, carregam o traço [+ volitivo], enquanto constituinte Inativo prototípico é afetado de maneira involuntária no EsCo, ou seja, carrega o traço [- volitivo] ${ }^{57}$. A associação entre a função semântica e essas categorias de volitividade (voluntariedade), por exemplo, é que diferencia, sentenças como (27) e (28):

\section{César destruiu a cidade.}

\section{A tempestade destruiu a cidade ${ }^{58}$.}

Em (28), apesar de o constituinte a tempestade não ter volitividade, ele não é a entidade afetada pelo EsCo (e, por isso, não pode ser considerada como Inativo).

Apesar de a nomenclatura Locativo talvez induzir a que pensemos que essa função designa apenas a localização de um EsCo (o que, tradicionalmente, poderia ser expressa por adjuntos adverbiais de lugar, por exemplo, e que, na GDF são atribuídas a modificadores e operadores), na GDF o Locativo é um termo argumental com o traço [+loc] e apresenta uma vasta gama de possibilidades de sentidos, indicando não só o lugar onde ocorre o EsCo, mas podendo indicar, também, por exemplo, a fonte do movimento (Origem), o caminho do movimento (a direção ou o Destinatário), o ponto final do movimento (ou seja, a meta espacial), a entidade causadora do movimento, entre outros. É o que ocorre no exemplo (24), que retomamos abaixo agora de maneira simplificada, e do exemplo (29), que acrescentamos para o EP:

(24) a gente vai <mandar / o'> / e-mail pra / tal pessoa / <pra falar> + (C-ORAL-BRASILbfamcv01).

\footnotetext{
56 Preferimos usar a sigla $A t$, para diferenciá-la da sigla $A$, que usamos para indicar Ato Discursivo.

57 The prototypical Actor is volitionally involved in the State-of-Affairs and the prototypical Undergoer is non-volitionally affected by the State-of-Affairs [...] (HENGEVELD \& MACKENZIE, ps. 2484).

58 Exemplos adaptados de Hengeveld \& Mackenzie (2008).
} 
(29) $\quad{ }^{*} \mathrm{CRI}:[<]<j a h$ ! / claro $>/ / \$$ me llamaste desde el $+\$$ es que me [/] se fue a la sierra / y me llamó desde la sierra // $\$$ [Ah, claro, me ligaste da $+\$$ é que me [/] se foi à serra e me ligou desde a serra] / [Ah, claro, você me ligou da $+\$$ é que me [/] foi embora pra serra e me ligou de lá] (C-ORAL-ROM-efamdl08).

[se foi à serra]

[foi embora pra serra]

Em (24), o termo para tal pessoa é o argumento Locativo com o sentido de ponto final do movimento, ou seja, indica o Destinatário. Em (29), o Locativo é representado pelo termo a la sierra, indicando Destino. Vale observar que o termo desde la sierra indica lugar de origem do Movimento, mas não o consideramos em nossa análise por não ser um constituinte argumental/Configuracional, que é o foco de nosso trabalho.

Em EsCos dinâmicos com Propriedades configuracionais de predicação de dois lugares, no Nível Morfossintático, é possível combinar as três funções semânticas de diferentes maneiras $(A t+I / I+A t / A t+L / L+A t / I+L / L+I)^{59}$, enquanto nas de três lugares, necessariamente as três funções semânticas estarão presentes $(A t+1+L / A t+L+\mid$ / $I+A t+L / I+L+A t / L+A t+I / L+I+A t)$. Essas diferentes combinações são muito importantes para nossas análises, pois, como pretendemos demonstrar, em PB, a função semântica é fundamental para o posicionamento dos constituintes nos Moldes Predicativos, como veremos na próxima subseção, ao apresentarmos o terceiro Nível do Componente Gramatical: o Morfossintático.

\subsubsection{Nível Morfossintático}

No Nível Morfossintático ocorrem as representações estruturais das unidades linguísticas. É onde, portanto, manifestam-se as diferentes ordenações dos constituintes. No nosso exemplo a respeito da intenção de aviso de alerta sobre a existência de um cachorro enorme, a ordem das Palavras característica de construções existenciais, construídas, em PB, como vimos antes, pelos verbos ter ou haver seguido de um sintagma nominal, é um exemplo de como as configurações dos níveis Interpessoal e Representacional são traduzidas em estruturas morfossintáticas. Essa tradução nos indica algo fundamental: muito do que ocorre no nível

\footnotetext{
59 Lembrando que At: Ator; I: Inativo e L: Locativo.
} 
Morfossintático é funcionalmente motivado, embora haja também arbitrariedade (por exemplo, em uma ordem básica de constituintes oracionais que não é funcionalmente motivada).

Assim como os outros níveis, este também é hierarquicamente organizado, sendo constituído pelas seguintes camadas:

$$
\begin{gathered}
\text { Expressão Linguística (Le) } \rightarrow \text { Oração }(\mathrm{Cl}) \rightarrow \text { Sintagma }(\mathrm{XP}) \rightarrow \text { Palavra } \\
(\mathrm{XW}) \rightarrow \text { Raiz }(\mathrm{XS}) \rightarrow \text { Afixos }(\text { Aff }) .
\end{gathered}
$$

Esquema 4 - Camadas do Nível Morfossintático

Como se vê no esquema acima, a Expressão Linguística é a camada mais alta deste nível e se refere ao conjunto de pelo menos uma unidade morfossintática. Uma Expressão Linguística é qualquer conjunto de pelo menos uma unidade morfossintática, incluindo holófrases (como Socorro!, Bem-vindo! e Silêncio!) e expressões não sentenciais, já que podem ser formadas por Orações, Sintagmas ou Palavras.

Retomando as funções semânticas que descrevemos no Nível Representacional, constatamos que, no $\mathrm{PB}$, Ator iconicamente assume a posição à esquerda do predicado, enquanto Inativo e Locativo, assumem a posição à sua direita. Assim, em construções de EsCos dinâmicos e Propriedades de dois e três lugares, Ator se coloca, geralmente, à esquerda do Predicado, enquanto Inativo e Locativo, à direita do Predicado. Recuperamos, de maneira simplificada, alguns dos exemplos que citamos anteriormente, a fim de mostrar essa iconicidade do posicionamento dos constituintes argumentais em relação ao Predicado, no PB.

Nas Propriedades de predicação de um lugar, como vimos anteriormente, é possível que os únicos argumentos se posicionem à direita ou à esquerda do predicado, como sintetizamos no quadro a seguir. 


\begin{tabular}{|c|c|c|c|}
\hline Molde de Predicação & Exemplo & \multicolumn{2}{|c|}{ Posicionamento } \\
\hline \multirow{3}{*}{$\begin{array}{c}\text { Propriedade configuracional } \\
\text { de predicação de um lugar }\end{array}$} & $\begin{array}{c}\text { acontece uma coisa } \\
\text { interessante }\end{array}$ & acontece & $\begin{array}{c}\text { uma coisa } \\
\text { interessante }\end{array}$ \\
\cline { 2 - 4 } & & predicado & Inativo \\
\cline { 3 - 4 } & isso acontece & isso & acontece \\
\cline { 3 - 4 } & & Inativo & predicado \\
\hline
\end{tabular}

Esquema 5 - Molde de Predicação de Propriedades de predicação de um lugar

O esquema de posições dos constituintes de Propriedades Configuracionais de dois e três lugares, em PB, é mostrado no quadro seguinte:

\begin{tabular}{|c|c|c|c|c|c|}
\hline Molde de & Exemplo & \multicolumn{4}{|c|}{ Posicionamento } \\
\hline \multirow{2}{*}{$\begin{array}{l}\text { Propriedade } \\
\text { Configuracional } \\
\text { de predicação } \\
\text { de dois lugares }\end{array}$} & \multirow{2}{*}{$\begin{array}{c}\text { Eu entendi } \\
\text { direitinho o } \\
\text { desenho que ele } \\
\text { fez pra mim, uai }\end{array}$} & $E u$ & entendi & \multicolumn{2}{|c|}{$\begin{array}{c}\text { o desenho que ele fez } \\
\text { pra mim } \\
\text { 60 }\end{array}$} \\
\hline & & Ator & predicado & \multicolumn{2}{|c|}{ Inativo } \\
\hline \multirow{2}{*}{$\begin{array}{l}\text { Propriedade } \\
\text { Configuracional } \\
\text { de predicação } \\
\text { de três lugares }\end{array}$} & \multirow{2}{*}{$\begin{array}{l}\text { A gente vai } \\
\text { mandar o e-mail } \\
\text { pra tal pessoa }\end{array}$} & A gente & vai mandar & o e-mail & $\begin{array}{l}\text { para tal } \\
\text { pessoa }\end{array}$ \\
\hline & & Ator & predicado & Inativo & $\Rightarrow$ \\
\hline
\end{tabular}

Esquema 6 - Posições dos constituintes de Propriedades Configuracionais de dois e três lugares, em PB

O quadro acima mostra que, nos nossos exemplos, em PB realmente os constituintes com função semântica Ator posicionam-se iconicamente à direita dos predicados, enquanto os com funções Inativo e Locativo, posicionam-se à sua direita. No entanto, motivações pragmáticas, informatividade dos constituintes e tipos de predicados e de argumentos podem interferir nesses posicionamentos icônicos, como ocorre, por exemplo, se o Falante deseja enfatizar ou contrastar algum constituinte e, para alcançar tal efeito, reordena os constituintes de maneira não icônica e usa estruturas específicas, que detalharemos nos capítulos 4 e 5. Por ora, podemos supor

60 Não nos interessa aqui analisar os termos desse constituinte complexo, por isso, ainda sendo uma Oração subordinada, cujos termos têm diferentes funções semânticas, a analisamos como um bloco único, que funciona como o Inativo em relação ao predicado da Oração principal. 
que, ao invés de dizer algo como Eu esqueci de perguntar isso pra eles lá, o Falante recorresse a uma sentença clivada como Foi isso que eu esqueci de perguntar pra eles lá, em que o constituinte Inativo isso, que aparecia iconicamente à direita do predicado, aparece agora à sua esquerda, sendo, portanto, o constituinte com função pragmática de Contraste.

Vejamos agora se essas tendências de posicionamento de constituintes com funções semânticas são as mesmas em E, acrescentando outros exemplos aos já citados, a fim de mostrar algumas assimetrias entre as duas línguas e retomando também de maneira simplificada, os exemplos dados anteriormente. Vejamos primeiro os novos exemplos, para depois sistematizar todos em um quadro, como fizemos para o PB, relacionando as posições ocupadas pelos constituintes com funções semânticas dos três Moldes de predicação que selecionamos.

(30) *PAT: por eso / por eso la adelantaron //\$ es que dice ella que la adelantaron porque / tenían + \$ bueno / la casa la llevan haciendo como tres años //\$ o sea / tiene que tener una casa / alucinante //\$ porque el \&pa / \&eh [///] todos xxx meter allí mano //\$ y / es una casa muy grande / de dos pisos / de <estos antiguos> +\$ (C-ORAL-ROM-efamcv05)

[a casa a levam fazendo como três anos] [estão fazendo a casa há mais ou menos três anos]

(31) *PAC: Tolueno / Sileno ...\$ como / desde biferilo / xxx / hay un montón de / compuestos tóxicos //\$ y / la mayoría de estos se los comen / las seudómonas //\$ entonces la cosa es / \&comprend +\$ porque lo que pasa es que a ver / nosotros en el laboratorio / conseguimos que \&cre [/] que crezca comiendo Sileno / no (C-ORAL ROM epubdl15)

[a maioria desses $\varnothing$ os comem as pseudômonas]

[As pseudômonas comem a maioria deles (dos compostos)].

Pareceu-nos interessante apontar que pouquíssimas ocorrências em nosso corpus nas quais aparece o verbo decir [dizer] em $\mathrm{E}$, em qualquer tempo, teve um constituinte sintagmático (ou seja, não oracional) Inativo à sua direita. De fato, as ocorrências mostraram que o tipo de complemento mais recorrente para este verbo foi oracional como Me vas a decir que lo sabías (C-ORAL-ROM-efamcv07), porém, como esse tipo de estrutura foge ao escopo desta pesquisa, não a analisaremos aqui. O que nos interessa observar é que não houve nenhuma ocorrência da estrutura Ativo + dizer + Inativo + Locativo, como em sentenças como Yo dije eso a mi madre [Eu disse isso a/para minha mãe]. Vejamos outros dois exemplos com o verbo decir: 
(32) ${ }^{*} E L E:[<]<c l a r o>/ / \$$ pero es que yo eso se lo he dicho cien mil veces $/ / \$$ le he dicho Fran / yo no te quiero hacer daño / de verdad / o sea / es que no quiero //\$ el otro / que no $/ / \$$ que no $/ / \$$ que yo estoy bien $/ / \$$ que yo <estoy bien> $/ / \$$ (C-ORAL-ROM-efamcv10)

[mas é que eu isso lhe o disse cem mil vezes]

[mas é que eu disse isso cem mil vezes para ele] ${ }^{61}$.

(33) *UEL: bueno / pues eso //\$ que / la obra / a Cristina le gustó bastante //\$ pero bueno / coincidimos al final en que la puesta / en / no sé cómo / <lo dice / Cristina > //\$

${ }^{*}$ OÑO: $[<]<$ la puesta en> escena?\$

*UEL: sí //\$ o la dirección artística / o no sé //\$ o la dirección / \&eh [/] dirección de escena / no sé / cómo lo decía ella // \$ (C-ORAL-ROM-efamdI20)

[o diz Cristina] / [diz Cristina]

[o dizia ela] / [ela dizia].

O mesmo ocorreu com outros predicados de três lugares, como vemos a seguir com os predicados dar (como vimos no exemplo 25 - cien millones le daba Tómbola a Telemadrid ) e pegar [bater/dar uma surra], como vemos em (34).

*PAL: juro / que quiero que gane el Real Madrid //\$ <totalmente / eh> ?\$

*USE: $[<]<$ ya $/ / \$$ ya $>/ / \$$

*PAL: o sea $/<10>\$$

${ }^{*} P R I:[<]<y a>/ / \$$

${ }^{*} P A L:$ / juro / total> //\$

${ }^{*} P R I:$ ya $/ / \$$

${ }^{*} P A L:<$ pero $>$...\$

${ }^{*} P R I:[<]<$ para> que no te pegue tu marido <una paliza> //\$ (C-ORAL-ROMefamcv07)

[para que não te bata teu marido uma surra]

[para que teu marido não te dê uma surra].

Vejamos, portanto, no quadro a seguir o esquema de posicionamento dos constituintes argumentais e suas respectivas funções semânticas:

61 Aqui, preferimos traduzir o pronome se, do E, por para ele, em PB, por se tratar de uma terceira pessoa (disse isso para o Fran), como identificamos no contexto, e para manter a informalidade, já que o pronome lhe, em PB, parece ser mais formal, além de poder ser usado, em determinadas variedades da língua, para referir-se a uma segunda pessoa, como equivalente de te. 


\begin{tabular}{|c|c|c|c|c|c|c|}
\hline $\begin{array}{l}\text { Molde de } \\
\text { Predicação }\end{array}$ & Exemplos & \multicolumn{5}{|c|}{ Posicionamento } \\
\hline \multirow{4}{*}{$\begin{array}{l}\text { Predicação } \\
\text { de um lugar }\end{array}$} & \multirow{2}{*}{$\begin{array}{l}\text { eso pasa } \\
\text { siempre }\end{array}$} & \multicolumn{2}{|c|}{ eso } & \multicolumn{3}{|c|}{ pasa } \\
\hline & & \multicolumn{2}{|c|}{ Inativo } & \multicolumn{3}{|c|}{ Predicado } \\
\hline & \multirow{2}{*}{$\begin{array}{c}\text { siempre pasa } \\
\text { eso }\end{array}$} & \multicolumn{2}{|c|}{ pasa } & \multicolumn{3}{|c|}{ eso } \\
\hline & & \multicolumn{2}{|c|}{ Predicado } & \multicolumn{3}{|c|}{ Inativo } \\
\hline \multirow{8}{*}{$\begin{array}{c}\text { Predicação } \\
\text { de dois } \\
\text { lugares }\end{array}$} & \multirow{2}{*}{$\begin{array}{c}\text { ésta ha } \\
\text { hecho } \\
\text { primaria }\end{array}$} & ésta & ha hecho & \multicolumn{3}{|c|}{ primaria } \\
\hline & & Ator & Predicado & \multicolumn{3}{|c|}{ Inativo } \\
\hline & \multirow{2}{*}{$\begin{array}{c}y \text { tiene } \\
\text { trabajo allí el } \\
\text { chaval }\end{array}$} & tiene & trabajo & & el cha & val \\
\hline & & Predic. & Inativo & & Ato & \\
\hline & la casa la & la casa/la & Ilevan hac & iendo & & \\
\hline & $\begin{array}{l}\text { llevan } \\
\text { haciendo }\end{array}$ & Inativo & Predica & do & & \\
\hline & $\begin{array}{c}\text { la mayoría de } \\
\text { estos se los } \\
\text { comen las }\end{array}$ & $\begin{array}{l}\text { la } \\
\text { mayoría } \\
\text { de estos }\end{array}$ & $s e^{62}$ & $\operatorname{los}^{63}$ & omen & $\begin{array}{c}\text { las } \\
\text { seudómonas }\end{array}$ \\
\hline & seudómonas & Inativo & ------ & Inativo & redic. & Ator \\
\hline & te voy a decir & (yo) & te & voy & a decir & una cosa \\
\hline Predicação & una cosa & $\begin{array}{c}\text { Ator } \\
\text { (implícito) }\end{array}$ & Locativo & Pre & dicado & \\
\hline lugares & yo eso se lo & yo & eso & se & 10 & he dicho \\
\hline & $\begin{array}{c}\text { he dicho cien } \\
\text { mil veces }\end{array}$ & Ator & Inativo & Locativo & Inativo ${ }^{64}$ & Predicado \\
\hline & no te pegue & te & pegue & & narido & una paliza \\
\hline & tu marido una & Locativo & Predicad & & Ator & Inativo \\
\hline & $\begin{array}{c}\text { cien millones } \\
\text { le daba }\end{array}$ & $\begin{array}{c}\text { cien } \\
\text { millones }\end{array}$ & le & daba & Tómbola & $\begin{array}{c}a \\
\text { Telemadrid }\end{array}$ \\
\hline & $\begin{array}{l}\text { Tómbola a } \\
\text { Telemadrid }\end{array}$ & Inativo & $\begin{array}{l}\text { Locativo } \\
65\end{array}$ & Predicado & Ator & Locativo \\
\hline
\end{tabular}

Esquema 7 - Posicionamento dos constituintes argumentais e suas respectivas funções semânticas

62 Este constituinte não tem função semântica, de acordo com a GDF, já que faz parte do verbo, que, na verdade, é comerse. Em E, o pronome, neste caso, indica que a ação de comer foi realizada em sua totalidade, como se estivesse se falando que as seudómonas comem tudo, sozinhas.

63 Correferente a la mayoría de estos.

${ }^{64}$ Correferente a eso.

${ }^{65}$ Correferente a a Telemadrid. 
Como podemos visualizar no quadro acima, a princípio, parece não haver diferença de posicionamento dos constituintes de sentenças de Propriedade Configuracional de predicação de um lugar nas duas línguas, já que em ambas encontramos Inativos tanto à direita quanto à esquerda do predicado. Já em sentenças de Propriedade Configuracional de predicação de dois e de três lugares, em EP não há o mesmo grau de restrição de posicionamento de constituintes com função pragmática que existe em PB. Na maioria dos casos, aliás, a tendência de posicionamento em ambas as línguas é contrária: enquanto em $\mathrm{PB}$, como vimos, Ator tende a ocupar uma posição à esquerda do Predicado e Inativo e Locativo, uma posição à sua direita, em EP, frequentemente Ator aparece à direita do Predicado. Essa diferença entre as duas línguas é percebida de maneira ainda mais clara ao compararmos as traduções dos exemplos de EP para o PB, pois, na maioria dos casos, acreditamos que a forma mais usual em PB não mantenha a mesma ordenação que em EP.

Essa característica do EP se deve a diferentes fatores, como, por exemplo, algumas marcas morfológicas para marcar determinados tipos de Inativos, uso de clíticos correferenciais, uso de dativos, entre outros, dos quais falaremos ao longo deste e do próximo capítulo. Mas, por ora, os dados nos levam a uma constatação reveladora: as funções semânticas são mais restritivas para o PB que para o EP, com relação à ordem dos constituintes, ou, em outras palavras, as funções semânticas são mais relevantes para a ordenação em PB que em EP, que parece priorizar outras funções (especificamente as pragmáticas, como explicaremos no capítulo 5) como critério para a ordenação.

Os exemplos que demos aqui foram de $\mathrm{EsCos}$ que dizem respeito à realidade externa. Mas deve-se considerar também a existência de EsCos de realidade interna, ou seja, aqueles relacionados a processos, estados psicológicos e experiências. As experiências normalmente envolvem dois participantes: um Experienciador (com função Inativo) e o fenômeno que está sendo experimentado (com função Locativo). É o que ocorre nos exemplos (35), em que o constituinte eu tem a função de Inativo/Experienciador e o constituinte de inglês tem a função de Locativo/entidade causadora da experiência, e (36), em que os termos pronominais a mí e me indicam o Experienciador (referindo-se a um yo [eu] e o termo el sitio ese, ainda tendo a função sintática de Sujeito, indica o Locativo. Aqui, temos uma diferença entre o PB e o EP, 
já que, em EP, não é o Sujeito que tem a função de Experienciador, como ocorre no PB:

(35) *MAR: ah / eu acho que é + ah / é por causa que eu gosto mesmo de inglês / <né> // (C-ORAL-ROM-bpubdl11).

*PAT: [<] <ya / a mí no me gustó> nada el sitio ese (C-ORAL-ROM-efamcv05).

Os casos que analisamos de constituintes com a função retórica de Orientação compõem a Expressão Linguística, mesmo estando fora dos limites da Oração. É o que ocorria em nosso exemplo (4), que usamos para explicar Ato Discursivo dependente, e que agora retomamos (marcado agora como 37) para exemplificar o nível de Expressão Linguística:

(37) *BRU: mas a sua bolsinha é linda hhh // gente / o Tommaso / durante o negócio / ele tava vendo jogo de futebol na internet / cê acredita // (C-ORAL-BRASIL-bfamcv22).

Como já explicamos anteriormente, o sintagma nominal o Tommaso tem a função de dar a orientação do próximo Ato Discursivo e está fora da Oração (sendo, portanto, um constituinte com função retórica de Orientação, da qual falaremos com detalhes no capítulo 4), que é durante o negócio, ele tava vendo jogo de futebol na internet. Nota-se que a Oração está sintaticamente completa, ou seja, o molde de predicação está completo: o predicado ver, de Propriedade de dois lugares, tem seus dois argumentos expressos na Oração: ele (desempenhando a função sintática Sujeito e a função semântica Ator) e jogo de futebol (com o modificador na internet), com função semântica de Inativo. Assim, o constituinte o Tommaso aponta para o assunto, fornecendo uma direção discursiva ao Interlocutor (tanto que é retomado dentro da Oração por meio do pronome ele), e faz parte da Expressão Linguística, mas não da Oração.

A Oração $(\mathrm{Cl})$, formada por um ou mais Sintagmas $(\mathrm{XP})$ e provavelmente por Palavras (gramaticais), caracteriza-se por uma espécie de molde para a ordenação desses Sintagmas e Palavras e por apresentar expressões morfológicas de conexão entre eles (por exemplo, de regência e concordância). 
Os Sintagmas podem ser de vários tipos, dependendo do tipo de seu núcleo: Verbais, Nominais, Adjetivais, Adverbiais, etc. Cada língua particular apresentará seus tipos de Sintagmas, que não estão necessariamente presentes em todas as línguas.

A Palavra (XW) é formada por Radicais (XS) e Afixos (Aff) e em algumas línguas, também por Sintagmas e Orações. É interessante notar que a GDF diferencia Palavras de Lexemas, pois enquanto estes operam no Nível Representacional, as Palavras operam no Nível Morfossintático.

Também há uma diferenciação entre Palavras Lexicais e Palavras Gramaticais, já que as lexicais são introduzidas no Nível Morfossintático e são classificadas de acordo com sua distribuição sintática e conteúdo lexical. Já as Gramaticais correspondem a um operador ou a uma função no Nível Representacional ou Interpessoal.

Assim como nos outros Níveis do Componente Gramatical, o Nível Morfossintático abriga núcleos, modificadores e funções. Interessam-nos em particular as funções, para as quais abrimos um novo subitem.

\subsubsection{As funções sintáticas}

A GDF reconhece apenas duas funções sintáticas: o Sujeito (Subject) e o Objeto (Object), porém, segundo essa teoria, nem todas as línguas dispõem dessas funções. Em pesquisas bibliográficas e até mesmo em consultas que fizemos a pesquisadores da área, não encontramos uma definição clara para a função de Objeto (que se oporia à função de Locativo em determinadas línguas). As funções semânticas de Inativo e Locativo da GDF já são suficientes para as análises que propomos em PB e em EP, pois entendemos que, nessas línguas, a função Objeto, também nos moldes da GDF, não é muito pertinente, ao menos para nossas análises, e essa nomenclatura só será adotada neste trabalho para traçarmos um paralelo com o que já se tem dito amplamente pelos estudos de ordenação sob diferentes perspectivas teóricas. Lembramos que, para a GDF, Inativo e Locativo, bem como Ator, são funções que estão no Nível Representacional e não podem ser interpretadas como equivalentes a funções que seriam do Nível Morfossintático. No entanto, o que na GDF se denomina Ativo corresponde ao que tradicionalmente seria o Sujeito; o que se denomina Inativo corresponde ao Objeto Direto; e o Locativo, ao Objeto Indireto. 
Assim, em PB, retomando a questão que discutíamos na seção anterior, em uma Oração formada por dois constituintes argumentais igualmente adequados semanticamente para designarem tanto Atores como Inativos, sua ordenação em relação ao argumento é que os diferenciará e determinará suas respectivas funções. Se pensarmos, por exemplo, em constituintes que designam pessoas, como a Júlia, cognitivamente, sabemos que esse constituinte pode ser tanto um Ator (volitivo ou não), como um Inativo, ou ainda como um Locativo. Esse constituinte, portanto, poderia assumir diferentes funções sintáticas, como mostramos a seguir, a partir desse par de exemplos criados por nós:

A Júlia encontrou (a) Maria.

(39) Eu encontrei a Júlia no mercado.

Em (38), a Júlia é um constituinte com função semântica Ator e, sintaticamente, é o Sujeito. Em (39), é Inativo, com função sintática de Objeto. Vemos que, em PB, não dispomos de nenhum morfema para a diferenciação dessas categorias. A distinção entre (38) e (39) se dá pelo posicionamento desse termo em relação ao predicado: como vimos anteriormente, em $\mathrm{PB}$, iconicamente e em EsCos dinâmicos, de Propriedades Configuracionais de predicados de dois e três lugares, a posição à esquerda do predicado marca Ativo e a posição à direita, marca Inativo (ou Locativo), ou seja, a diferenciação das funções ocorre por meio do alinhamento.

Em (39) o constituinte Ator eu tem a função de Sujeito, pois é ele que corresponde à desinência verbal número-pessoal, já que encontrei seleciona um argumento Ator que corresponda ao Falante. Em outras palavras, o Sujeito é uma categoria gramatical (por isso é atribuído no Nível Morfossintático) que se relaciona à concordância do verbo. O Sujeito, portanto, é uma categoria morfossintática que, em PB e em EP, muitas vezes coincide com a função semântica de Ator (em EsCos dinâmicos), no Nível Representacional, e com a função pragmática de Tópico, no Nivel Interpessoal. Essas foram as razões pelas quais preferimos diferenciar essas categorias ao invés de simplesmente falar da ordenação do Sujeito e do Objeto em relação ao verbo (ou seja, falar de ordenações do tipo SVO e suas diferentes configurações), como tradicionalmente têm-se feito nos estudos sobre ordenação, conforme apresentado no capítulo Zero. 
Como já apontamos na seção anterior, o espanhol tem uma maior liberdade de ordenação que o PB, já que depende em menor grau da ordenação em si para diferenciar as funções semânticas de seus constituintes. Isso é possível porque, entre outras características dessa língua, no espanhol há a marcação morfológica (preposição a) antes de constituintes com função semântica Inativo e que se refiram a outro constituinte com o traço [+específico]. Essa característica permite uma maior liberdade dos constituintes com função de Inativos, diferentemente do PB, como dissemos anteriormente, que depende em maior medida do posicionamento desses constituintes para ser diferenciado de Ator. Vejamos o seguinte exemplo em EP:

(40) ${ }^{*} E L E:[. .$.$] y entonces estamos en casa de Aitana / y de pronto se empieza a agobiar$ Aitana un montón / pensando que vaya plan de mierda / hemos hecho para ir a la sierra //\$ (C-ORAL-ROM-efamdl08)

[e de repente começa a se agoniar/se irritar Aitana um monte]

[e de repente a Aitana começa a se irritar um monte ]

Nenhum hispanoparlante interpretaria o constituinte Aitana como Inativo: não haveria dúvidas de que se trata do Sujeito/Ator da Oração. Essa certeza deve-se à ausência da preposição $a$, obrigatória para atribuir a função de Inativo a constituintes desse tipo. Se compararmos (40) com a hipotética ocorrência (41), criada por nós, teríamos:

\section{[...] y de pronto se empieza a agobiar a Aitana un montón [...]}

[e de repente começam a irritar/a incomodar a Aitana]

Em (41), portanto, o constituinte preposicionado a Aitana tem a função de Inativo, enquanto a desinência do verbo, acompanhada do pronome se indicaria um Sujeito/Ator indeterminado (o que caracterizaria um enunciado passivo).

Temos em (40) uma daquelas estruturas a que nos referimos na Introdução deste trabalho e que geram muitas dificuldades de interpretação para os alunos brasileiros de espanhol como língua estrangeira, visto que tendem a interpretar o constituinte à direita do predicado como o Objeto da Oração, como fazem no PB.

Embora na maioria dos materiais didáticos de $\mathrm{E}$ como língua estrangeira, explique-se que a preposição a deve ser usada antes de objetos diretos [+humanos], 
Yokota (2001) nos alerta para a problemática dessa generalização. Ao estudar a marcação de caso acusativo nas produções em $\mathrm{E}$ de alunos brasileiros, a pesquisadora observa que "A presença de a com complemento indireto é obrigatória, entretanto, no caso do objeto direto, a preposição pode ser: opcional, obrigatória ou proscrita" (YOKOTA, 2001, p. 63).

Dentre os casos de proscrição, independentemente de o Objeto carregar ou não o traço [+humano], a autora cita as orações passivas e as existenciais construídas com o verbo haber. Como exemplos agramaticais, Yokota (2001, p. 63) traz as seguintes sentenças:

${ }^{*}$ Fueron visitadas a varias delegadas del congreso.

[*Foram visitadas a várias delegadas do congresso]

*Hay a varias delegadas en la sala.

[Há a várias delegadas na sala].

Segundo a pesquisadora, a preposição a geralmente é opcional antes de objetos indefinidos, mas essa não é uma regra, já que determinados verbos exigem a preposição. O que a autora conclui é que o uso da preposição é obrigatório quando acompanha um objeto direto que designa uma entidade animada e afetada pelo verbo, daí a diferença entre esse trio de exemplos trazidos por ela:
(44a) Odia a un vecino [Odeia a um vizinho]
(44b) *Odia un vecino [Odeia um vizinho]
(44c) *Odia a las acelgas [Odeia às acelgas]

Se o objeto é definido, no entanto, há a obrigatoriedade da preposição, daí a agramaticalidade de (45a) em comparação a (45b):

$\begin{array}{lll}\text { (45a) } & \text { *Trajeron el policía } & \text { [Trouxeram o policial] } \\ \text { (45b) } & \text { Trajeron al policía } & \text { [Trouxeram ao policial] }\end{array}$

Yokota (2001) aborda, então, um ponto crucial para nossa pesquisa, ao comparar as seguintes sentenças: 
(46a) (?) Perseguía el guardia el ladrón

[?Perseguia o guarda o ladrão]

(46b) Perseguía al guardia el ladrón

[Perseguia ao guarda o ladrão] / [O ladrão perseguia o guarda]

46c) Perseguía el guardia al ladrón

[Perseguia o guarda ao ladrão] / [O guarda perseguia o ladrão]

A pesquisadora diz que:

Em certas situações sintáticas, a animacidade e a especificidade do objeto preposicional fazem com que se produza ambiguidade nas funções gramaticais de sujeito e objeto. A preposição, ao marcar o objeto, desfaz a ambiguidade. Note-se que neste caso [dos exemplos dados] a mobilidade dos termos da oração gera a ambigüidade. Se tivéssemos a sequência SVO, a identificação de sujeito e objeto não seria um problema. Em português, apesar de esta situação estar prevista na gramática normativa, não é uma estrutura comum, sendo mais usual a sequência SVO (O guarda perseguia o ladrão / O ladrão perseguia o guarda). Em espanhol, ao contrário, a presença da preposição é um elemento desambiguador mais comum que a ordem SVO (YOKOTA, 2001, p. 64-65).

A citação acima corrobora aquilo que havíamos dito na seção anterior, sobre o E ter mais marcas morfossintáticas para diferenciar Sujeito e Objeto, o que lhe permite uma maior flexibilidade de ordenação que o PB, já que este depende em maior grau unicamente da ordenação para veicular funções semânticas e sintáticas dos constituintes. Vejamos mais um par de exemplos de nosso corpus:

(47) *PIL: eso si //\$ te tienes que buscar formas / porque si no / puedes entrar en picado / si no <sales $>/ / \$$ (C-RAL-ROM-efamdI01).

[você tem que procurar maneiras]

(48) *SEV: pues yo / \&mm / andaba / buscando una persona para / cuidar a una persona mayor $/ / \$$ a una <mujer> //\$ (C-RAL-ROM-epubdl07).

[pois eu andava procurando uma pessoa para cuidar a uma pessoa idosa, a uma mulher] [pois eu ando procurando uma pessoa para cuidar de uma pessoa idosa, (de) uma mulher] 
Embora (47) e (48) tenham o mesmo molde de predicação, construídas inclusive com o mesmo verbo (buscar), vemos que em (47), o constituinte formas, com função de Inativo, não aparece preposicionado, justamente por ter o traço [- humano]. Isso já basta para que ele não seja preposicionado (sem a necessidade de recorrer à definitude/especificidade). Já em (48), o contexto conversacional é o de um senhor que chega a uma agência de recrutamento de funcionários, procurando contratar os serviços de alguém que cuide de seu pai, que está doente. O argumento Inativo de buscar tem o traço [+humano] e se manifesta de duas maneiras: na primeira, o Inativo não contempla o traço [+específico/determinado] e, por isso, aparece sem a preposição. O Falante, porém, sente a necessidade, depois, de especificar que a pessoa que está procurando deve ser mulher. Para isso, recorre a um constituinte extraoracional $^{66}$ (a una mujer), que, por conter o traço [+ específico], é marcado com a preposição a. É interessante observar que apenas o contexto maior da conversa nos permitiu interpretar esse termo como específico (una mujer em contraste com una persona), pois, ainda que não se saiba qual mulher (não se busca uma mulher específica), ainda assim há a especificidade mulher (a pessoa contratada não pode ser homem). No caso do Predicado cuidar, temos um Inativo que se refere ao pai do Falante, portanto a uma pessoa específica, por isso, também aparece preposicionado (a una persona). É preciso observar, no entanto, que essa diferenciação dos tipos de Ativos no espanhol não altera a função semântica do constituinte, nem lhe dá um estatuto sintático. O mesmo ocorre em PB, quando temos sentenças com o que a GT chama de objeto direto preposicionado.

Embora tenhamos marcado os traços definitude/especificidade entre barra, não significa que sejam termos sinônimos. Para explicar e diferenciar os termos definido/indefinido e específico/não específico, trazemos as palavras de Pezatti \& Fontes (2010, p. 187):

Identificabilidade envolve dois aspectos: o primeiro relaciona-se à concepção do Falante sobre a identificabilidade do referente pelo Ouvinte. Isso se refletirá nos operadores $\{+i d,-i d\}$ para identificável e não-identificável respectivamente. O segundo, por sua vez, relacionase à indicação pelo Falante da identificabilidade do referente para si próprio. Isso se refletirá nos operadores $\{+s,-s\}$ para específico e nãoespecífico.

\footnotetext{
${ }^{66}$ Funcionando aqui com a função retórica de Correção/Esclarecimento. Vemos que as barras duplas (//) na transcrição marcam uma pequena pausa e uma mudança de tessitura (que pode ser corroborada pelo áudio), comprovando que esse constituinte está fora do campo da Oração.
} 
Portanto, a explicação acima pode ser esquematizada da seguinte maneira:

- Determinado/indeterminado $\rightarrow$ Falante

- Específico/inespecífico $\rightarrow$ Ouvinte

Segundo Leonetti (1999, p. 38), "A definitude é a indicação de que o referente do SN [Sintagma Nominal] é identificável para o receptor no contexto de uso67". O conceito de identificabilidade é explicado por Leonetti (1999, p. 39) como a pressuposição de que o leitor pode construir uma representação mental adequada do referente, sem ambiguidade. Um referente não ambíguo significa um referente único, o que corresponde ao que o autor denomina condição de unicidade (condición de unicidad), segundo a qual "[...] o referente deve ser o único objeto (ou grupo de objetos) que satisfaça a descrição trazida pelo SN no contexto de uso 68" (LEONETTI, 1999, p. 39). A ideia de unicidade não significa que o referente seja único no mundo, mas sim que seja o único relevante para aquela situação discursiva em curso, e compartilhada pelo emissor e pelo receptor. Assim,

Em poucas palavras, os supostos que o receptor deve acessar para que o referente seja univocamente identificável podem estar contidos no SN definido, ou no contexto linguístico anterior, ou na situação de fala, ou também no conhecimento de mundo dos falantes (LEONETTI, 1999 , p. 40) ${ }^{69}$.

O autor diz ainda que essa noção de definitude muitas vezes é interpretada de maneira diferente por alguns gramáticos, que supõem que os Sintagmas nominais definidos são aqueles conhecidos ou familiares para o receptor. De fato, embora não seja uma condição necessária, esse conhecimento compartilhado existe na maioria dos casos, quando há a presença de artigos, pronomes ou demonstrativos. Esses

67 Tradução nossa do original: "La definitud es la indicación de que el referente del SN es identificable para el receptor en el contexto de uso".

68 Tradução nossa do original: "[...] el referente debe ser el único objeto (o grupo de objetos) que satisfaga la descripción aportada por el SN en el contexto de uso".

69 Tradução nossa do original: "En pocas palabras, los supuestos a los que el receptor tiene que acceder para que el referente sea unívocamente identificable pueden estar contenidos en el SN definido, o en el contexto lingüístico anterior, o en la situación de habla, o también en el conocimiento del mundo de los hablantes". 
traços também são essenciais para a identificação das funções pragmáticas de Tópico e Foco, como mostraremos no capítulo 4.

Além da natureza do Objeto, outros fatores também influenciam o uso ou a ausência da preposição a em E, como o tipo de Sujeito (Sujeitos não agentivos/não causantes proscrevem a preposição), telicidade ${ }^{70}$ dos verbos, a presença ou não de quantificadores e de possessivos, entre outros. Não abordaremos essas questões em nosso trabalho. No entanto, Yokota (2001) aponta para outra questão de fundamental interesse para nós: a relação entre topicalização e duplicação, dos quais falaremos nos capítulos 3 e 4, após termos explicado o conceito de Tópico do ponto de vista da GDF.

Ainda sobre o Sujeito nas línguas, Hengeveld \& Mackenzie (2008) nos falam que, devido ao caráter antropocêntrico da linguagem, os Falantes tendem, cognitivamente, a identificarem-se mais com Ativos que com Inativos ou Locativos. Em outras palavras, os Falantes têm uma percepção linguística do constituinte que desempenha a função de Sujeito em uma Oração, com fortes tendências cognitivas a sempre relacionar o constituinte Ativo a essa sintática ${ }^{71}$. Os autores apresentam, inclusive, baseados na Teoria da Otimidade, de autores como Comrie (1989) e Aissen (2003) (ambos apud HENGEVELD \& MACKENZIE, 2008, ps. 632), uma hierarquia de constituintes que cognitivamente são mais ótimos para desempenharem a função de Sujeito nas línguas (ou seja, são mais prototípicos):

\footnotetext{
Pronome pessoal $\rightarrow$ Nome próprio $\rightarrow$ Sintagma nominal definido $\rightarrow$ Sintagma nominal indefinido e específico $\rightarrow$ Sintagma nominal não específico
}

Esquema 8 - Hierarquia de Otimidade dos Sujeitos

\footnotetext{
70 Torrego Salcedo (1999, p. 1787, apud YOKOTA, 2001, p. 65) toma esta classificação e explica que: “La idea central sobre los verbos clasificados como 'realizaciones' y 'logros' es que expresan eventos con un límite temporal intrínseco. Se trata de verbos que, sin adverbios u otras frases delimitantes de tiempo, implican una acción terminada (...) Estos verbos se agrupan bajo el término 'télicos'.

${ }^{71}$ Isso é muito evidente em muitas situações em PB, quando, por exemplo, os Falantes tendem a interpretar sentenças como Ninguém lembrou do meu aniversário como orações sem Sujeito (já que não conseguem identificar um constituinte com função semântica de Ativo). Outra evidência para esse fato é a dificuldade em reconhecer o Sujeito Inativo em orações passivas como Vendem-se casas, em que muito provavelmente, o termo casas seria interpretado como Inativo (como Objeto Direto). Claro que estamos falando de análises cognitivas (de conhecimento inato da linguagem), que independem de instrução escolar.
} 
Terminamos aqui uma seção importante, que explica vários fatores que geram consequências nas diferentes ordenações dos constituintes no EP e no PB. Antes, porém, de falar sobre questões específicas de ordenação, resta-nos, ainda, apresentar, muito brevemente, o último Nível do Componente Gramatical da GDF: o Fonológico.

\subsubsection{Nível Fonológico}

O Nível Fonológico ${ }^{72}$ completa a codificação da gramática e contém tanto a representação segmental quanto a representação supra-segmental de um enunciado. Esse nível recebe o input dos três níveis anteriores e fornece o input para o componente de Saída. Esse nível ainda está dentro da gramática, pois é representado por fonemas (diferentemente do Componente de Saída, que trata de duração, intensidade, etc.).

As unidades componentes desse nível são as seguintes:

$$
\begin{gathered}
\text { Enunciado }(\mathrm{U}) \rightarrow \text { Frase Entonacional }(\mathrm{IP}) \rightarrow \text { Frase Fonológica }(\mathrm{PP}) \rightarrow \\
\text { Palavra Fonológica }(\mathrm{PW}) \rightarrow \text { Pé }(\mathrm{F}) \rightarrow \text { Sílaba }(\mathrm{S}) .
\end{gathered}
$$

Esquema 9 - Camadas do Nível Fonológico

Dessas unidades, a única que nos interessa abordar, mesmo que muito brevemente, é o Enunciado (U), que é a maior e mais importante parte com a qual lida o nível Fonológico. Hengeveld \& Mackenzie (2008) falam da dificuldade em delimitar precisamente essa camada, mas indicam que os Falantes tendem a utilizar pausas marcadas para separar Enunciados, sem que elas sejam interpretadas pelo ouvinte como hesitações. O Enunciado é, portanto, uma sequência autônoma.

Terminamos aqui nosso percurso pelos quatro níveis do Componente Gramatical: o Interpessoal, o Representacional, o Morfossintático e o Fonológico, detendo-nos nas camadas que são especialmente relevantes para nossa pesquisa.

O quadro seguinte sintetiza a hierarquia de todos os subníveis desses quatro níveis maiores:

\footnotetext{
${ }^{72}$ Faremos apenas uma breve apresentação deste nível, já que ele não constitui nosso objeto de estudo nesta tese, embora falemos, em alguns casos, de marcações prosódicas. Por isso não explicaremos cada um de seus níveis.
} 


\begin{tabular}{|c|c|}
\hline $\begin{array}{c}\text { Nível } \\
\text { Interpessoal }\end{array}$ & $\begin{array}{c}\text { Movimento }(\mathrm{M}) \rightarrow \text { Ato discursivo }(\mathrm{A}) \rightarrow \text { llocução } \\
(\mathrm{ILL}) \rightarrow \text { Falante }(\mathrm{P} 1) \rightarrow \text { Ouvinte }(\mathrm{P} 2) \rightarrow \text { Conteúdo } \\
\text { comunicado }(\mathrm{C}) \rightarrow \text { Subato de atribuição }(\mathrm{T} 1) \rightarrow \text { Subato } \\
\text { de referência }(\mathrm{R} 1) .\end{array}$ \\
\hline $\begin{array}{c}\text { Nível } \\
\text { Representacional }\end{array}$ & $\begin{array}{c}\text { Conteúdo Proposicional }(\mathrm{p}) \rightarrow \text { Episódio }(\mathrm{ep}) \rightarrow \\
\text { Estado-de-coisas }(\text { EsCo }) \rightarrow \text { Propriedade Configuracional } \\
(\mathrm{f}) \rightarrow \text { Propriedade Lexical } \rightarrow \text { Indivíduo }(\mathrm{x})\end{array}$ \\
\hline $\begin{array}{c}\text { Nível } \\
\text { Morfossintático }\end{array}$ & $\begin{array}{c}\text { Expressão Linguística (Le) } \rightarrow \text { Oração }(\mathrm{Cl}) \rightarrow \\
\text { Sintagma }(\mathrm{XP}) \rightarrow \text { Palavra }(\mathrm{XW}) \rightarrow \text { Raiz }(\mathrm{XS}) \rightarrow \text { Afixos } \\
\text { (Aff). }\end{array}$ \\
\hline Nível Fonológico & $\begin{array}{c}\text { Enunciado }(\mathrm{U}) \rightarrow \text { Frase Entonacional }(\mathrm{IP}) \rightarrow \text { Frase } \\
\text { Fonológica }(\mathrm{PP}) \rightarrow \text { Palavra Fonológica }(\mathrm{PW}) \rightarrow \text { Pé }(\mathrm{F}) \rightarrow \\
\text { Sílaba }(\mathrm{S}) .\end{array}$ \\
\hline
\end{tabular}

Esquema 10 - Hierarquia de todas as camadas dos quatro Níveis da GDF

Cabe lembrar que, na arquitetura geral da GDF, acima do Componente Gramatical, que abrange todas as camadas expressas no quadro, está o Componente Conceitual e, no nível mais baixo, está o Componente de Saída. Esses três níveis são permeados pelo Componente Contextual.

No capítulo seguinte, abordaremos, sob a perspectiva da GDF, a questão central deste trabalho, que é a ordenação dos constituintes. Para tal, nos basearemos principalmente nas camadas e nas inter-relações entre os níveis Interpessoal e Morfossintático, e principalmente nos Moldes de Conteúdo e de Predicado e nas funções semânticas, explicados neste capítulo. 


\title{
CAPÍTULO 3
}

\section{A ORDENAÇÃO DOS CONSTITUINTES NA GDF}

\author{
Uno quiere entrar en el desorden para ver qué orden \\ hay, uno quiere encontrarles leyes, encontrar \\ elementos comunes a ese desorden. Eso es lo que \\ hacemos nosotros.
}

(Roberto Markarian)

\subsection{Princípios Gerais}

Como já fomos apresentando nos capítulos anteriores, segundo a GDF, a ordenação dos constituintes não ocorre de maneira aleatória, pois é motivada pelas intenções comunicativas dos Falantes, o que vale dizer que é regida por questões relativas à Pragmática e à Semântica, como lemos na seguinte citação:

A ordenação dos constituintes na sentença, vista sob o arcabouço teórica da GDF, representa um dos meios de expressão formal de relações e funções, resultante de princípios pragmáticos e semânticos que determinam a colocação dos elementos na oração, de tal modo que ordens alternativas podem ser usadas em diferentes condições e para diferentes propósitos. Dito em outros termos, a ordenação dos constituintes é um dos meios de expressar formalmente relações e funções que variam de acordo com as intenções comunicativas do falante [...]. (PEZATTI \& CAMACHO, 2017, p. 161).

Se a ordenação está relacionada à expressão formal, está, portanto, localizada no nível da codificação da língua, ou seja, no nível Morfossintático do Componente Gramatical. Há diferentes domínios de ordenação dos constituintes (a Oração, o Sintagma e a Expressão Linguística). Cada domínio está formado por constituintes lexicais (núcleos e dependentes) e por constituintes gramaticais (relatores/conectores e operadores). Cada domínio contém um tipo de núcleo (head) lexical, que é o constituinte principal do domínio e é o ponto de orientação para os 
demais elementos do mesmo domínio. No domínio da Oração, o núcleo é o verbo, enquanto o núcleo da expressão é a Pcentro, que corresponde à Oração.

Como a GDF se vale de alguns pressupostos teóricos estipulados por Dik (1997) como fonte para sua própria vertente teórica, nos parece interessante traçar um percurso, bastante breve, na verdade, sobre algumas ideias da GF (a Gramática Funcional) que podem ser consideradas precursoras do que a GDF versará sobre a ordenação dos constituintes. A seguir, portanto, recuperamos algumas reflexões de Dik.

Dik (1997, p. 391) afirma que "[...] nós precisamos de regras que assignem posições para os constituintes da estrutura subjacente na sequência linear em que eles podem realmente aparecer"73. Essas regras são chamadas de regras de colocação (placement rules). Nenhuma língua se adequa a todas as regras, mesmo porque muitas delas podem entrar em uma relação de tensão e competição e, por isso, segundo Pezatti (2014, p. 63), "Podem ser encontrados contraexemplos reais ou aparentes para alguns desses princípios e muitas complicações podem surgir [...]". A pesquisadora nos alerta, ainda, que é provável que alguns fenômenos de ordenação não sejam explicados por esses princípios, mas que, de modo geral, eles são suficientes.

As observações iniciais que Dik (1997, p. 392) faz sobre os princípios de ordenação são as seguintes:

(i) Regras de colocação são regras de expressão (Placement rules are expression rules): as regras de colocação fazem parte do componente de expressão de uma gramática funcional. Em outras palavras, a ordenação dos constituintes é uma das maneiras pelas quais as relações e funções da estrutura subjacente podem ser expressas formalmente.

(ii) As regras de colocação não são regras de movimento (Placement rules are not movement rules): os constituintes não são movidos de uma posição para outra (como defendem outras teorias linguísticas). Eles são alocados em sua posição final, ou seja, não passam por posições intermediárias até chegarem onde devem estar. Não existem, nessa teoria, portanto, os

\footnotetext{
73 Tradução nossa do original: [...] we need rules which assign position to the constituents of the
} underlying structure in the linear sequences in which they can actually appear. 
conceitos de inversão nem de deslocamento, por exemplo, em que se toma uma sequência como sendo a básica (as sentenças declarativas do inglês, por exemplo, em que o verbo aparece posposto ao Sujeito) e as compara com as sentenças interrogativas (em que o verbo aparece anteposto ao Sujeito). Ao invés disso, as regras atribuem posições para elementos que ainda não têm posição e relacionam as funções subjacentes com a expressão (sequência superficial). Com isso, criam-se esquemas de posições (templates).

(iii) A ordenação dos constituintes não é uma propriedade profunda das línguas (Constituent ordering is not a deep property of languages): a ordenação é mais um recurso superficial que, em maior ou menor medida, pode ser usado para expressar as relações subjacentes. Isso significa que não existe uma ordem básica e que a teoria da GF (e também da GDF) é apropriada para descrever quaisquer tipos de ordenação em línguas particulares. Isso também implica dizer que línguas tipologicamente classificadas como de ordem livre são, na verdade, línguas cujas regras de colocação veiculam uma carga funcional menor que as línguas de ordem fixa. (iv) Não há línguas de ordem livre (there are no free word order languages): uma língua que realmente tivesse uma ordenação de constituintes livre deveria permitir qualquer tipo de combinação entre eles, com a mesma comunicabilidade, o que não é possível, já que não existem línguas que não excluam certas sequências e quando há diferentes sequências em uma língua, elas refletem diferenças significativas entre elas. Desse modo, precisamos das regras de colocação mesmo nos idiomas considerados de ordem livre.

A partir desses apontamentos iniciais, Dik (1997) cria uma teoria multifuncional da ordenação dos constituintes e elenca nove princípios gerais de ordenação e doze princípios específicos. Os específicos são os que servem para estabelecer o padrão (ou os padrões) de ordenação das línguas particulares. Os gerais, como a nomenclatura já indica, são universais, podendo, portanto, ser verificados em todas as línguas naturais.

Também tomando por base os 21 princípios elencados por Dik (1997), a GDF estipula seus únicos três princípios de ordenação: o da Integridade de Domínio, o da 
Iconicidade e o da Preservação das Relações de Escopo, dos quais falaremos no subitem a seguir.

\subsubsection{Princípio de integridade de domínio}

Este princípio está baseado no Princípio Geral 4 (PG4) de Dik (1997), com o mesmo nome adotado pela GDF, Princípio de integridade de domínio, e estipula que os constituintes preferem permanecer dentro de seu próprio domínio e que há uma preferência para que os domínios não sejam interrompidos por constituintes de outros domínios. Assim, por exemplo, se um constituinte é oracional, ele se manterá no domínio da Oração.

\subsubsection{Princípio de ordenação icônica}

A ideia de iconicidade não é um conceito exclusivo do Funcionalismo ou da GDF. Ela já era discutida por filósofos clássicos, depois foi retomada por Peirce (2017) no final do século XIX na distinção entre ícone, índice e símbolo, e também estava prevista em autores como Greenberg (1966), segundo o qual a ordem dos elementos na língua é fruto da ordem de conhecimentos decorrentes da experiência física. É também um conceito caro para autores funcionalistas como Givón (1991), por exemplo, e Dik (1997, p. 399), ao dizer que "[...] a ordenação de orações em um texto deverá, no caso não marcado, refletir a ordem dos elementos que ela descreve". De fato, o Princípio de ordenação icônica está baseado no Princípio Geral 1 (PG1) de Dik (1997).

Vimos anteriormente que, de acordo com a GDF, a eficiência de uma teoria linguística é proporcionalmente maior quanto maior for seu grau de aproximação ao modelo cognitivo dos Falantes. Dizer isso significa prever que o Princípio de Iconicidade permeia toda a teoria da GDF, já que a Iconicidade se baseia no estabelecimento de uma relação motivada entre forma e sentido. A GDF, portanto, sendo uma teoria funcionalista, se apropria desse princípio também. Para o funcionalismo, assim, a estrutura da língua não é arbitrária, já que reflete, de alguma forma, o pensamento e a estrutura da experiência humana. 
O princípio geral da Iconicidade se manifesta através de três subprincípios: princípio da ordenação sequencial, princípio da quantidade e princípio da adjacência, a partir dos quais, de acordo com Givón (1991), a gramática é construída.

\subsubsection{Subprincípio de ordenação sequencial}

Este subprincípio defende que há uma relação entre a ordenação de Sintagmas e o tipo de informação veiculada por eles. Existem duas tendências de ordenação sendo que, uma delas, de acordo com Marques (2012, p. 34-35), "[...] relaciona-se ao chamado subprincípio da relação entre ordem sequencial e topicalidade, segundo o qual a ordem dos elementos em um enunciado evidencia a ordem de sua importância para o falante"; a outra "[...] corresponde ao chamado subprincípio da ordenação linear, que prevê o reflexo da ordem que os fatos realmente se deram na ordenação das orações de um período". Neste caso, a iconicidade se manifesta em seu sentido básico, ou seja, obedece à sequência real dos acontecimentos, revelando a motivação cognitiva que gerou esta estrutura.

Como exemplo, podemos citar uma narrativa cujas sentenças aparecem no texto na mesma sequência em que os fatos narrados ocorreram na realidade, como Ela acordou, se trocou, tomou café e saiu para trabalhar. Essa sequência foi gerada graças à motivação cognitiva do Falante, que tentou reproduzir iconicamente a ordem dos acontecimentos.

\subsubsection{Subprincípio da quantidade}

Conforme Marques (2012, p. 35), segundo esse subprincípio, "[...] quanto maior a informação, maior é a estrutura da construção gramatical utilizada para expressá-la. Assim, a complexidade de pensamento tende a refletir-se na complexidade de expressão.". Quanto maiores forem a frequência e a previsibilidade da informação, mais o elemento linguístico que a transmite tende a ter menos material linguístico, respeitando o princípio de economia da linguagem. Vejamos o seguinte exemplo: 
(1) *LEO: <não> // <se bem que tinha> tinha uns dois que falaram assim / gente / a gente perdeu no campo // a gente nũ perdeu por causa disso não // tipo / tinha + dois falaram isso // não / <a gente perdeu no campo / e tal> // (C-ORAL-BRASIL-bfamcv01).

O exemplo (1) nos mostra que o primeiro não, que frequentemente precede o verbo (e, portanto, é mais previsível), aparece em sua forma átona, reduzido foneticamente a uma nasalização. Em contrapartida, o segundo não, que aparece posposto ao verbo com a intenção de reforçar a ideia de negação, é usado em sua forma tônica, com mais material fonético, pois é menos previsível. Assim, o uso desse segundo não tem motivação icônica: recebe mais codificação por ser mais imprevisível.

\subsubsection{Subprincípio da adjacência}

O terceiro e último subprincípio que integra o princípio de Iconicidade é o da adjacência, em que:

(a) Entidades que estão próximas funcional, conceptual ou cognitivamente serão colocadas uma próxima da outra no nível da codificação, isto é, temporal e espacialmente.

(b) Operadores funcionais serão colocados próximos, temporal e espacialmente, no nível da codificação, às unidades conceptuais às quais eles são mais relevantes (MARQUES, 2012, p. 35-36)

Exemplificaremos o princípio da Iconicidade mais adiante, quando falarmos das posições ocupadas pelos constituintes hierárquicos, como Modificadores e Operadores de Atos Discursivos, por exemplo.

Como visto nesta subseção, o princípio de Iconicidade se opõe ao princípio da Arbitrariedade. No entanto, precisamos considerar a existência de forças que podem concorrer com a motivação icônica, resultando num aparente paradoxo. É o que pode ocorrer, por exemplo, se houver o traço [+contraste] em um enunciado, em que um constituinte, ao contrário do que se esperaria, pode ocupar uma posição diferente da que ocupa normalmente, como veremos mais adiante. 


\subsubsection{Princípio da Preservação das Relações de Escopo}

Este princípio está baseado no Princípio Geral 3 (PG3) de Dik (1997), chamado de Princípio de orientação centrípeta, segundo o qual a ordem é determinada pela distância relativa dos constituintes em relação ao núcleo. Segundo Dik (1997, p. 402) "[...] a orientação centrípeta dos constituintes reflete a proximidade do vínculo entre os dependentes e o núcleo e as relações de escopo entre os dependentes". Como também veremos nas seções seguintes, os constituintes que ocupam PM obedecem a esse princípio, ocupando posições na sentença que vão das extremidades direita ou esquerda em direção ao centro, onde está o núcleo da sentença.

Esses são os três princípios da GDF nos quais nos basearemos para descrever as questões de ordenação de constituintes que selecionamos para este trabalho. A seguir, falaremos sobre as posições que a GDF propõe, bem como quais constituintes são aptos a ocuparem cada uma delas.

\subsection{O Esquema de posições na GDF}

\subsubsection{O sistema hierárquico}

Para a GDF, é necessário distinguir os elementos hierárquicos dos não hierárquicos para entender a ordenação dos constituintes em qualquer língua. Os hierárquicos são os que pertencem a camadas diferentes e que subordinam outros constituintes ou são a eles subordinados, enquanto os não hierárquicos (os da Propriedade Configuracional) pertencem à mesma camada e, portanto, têm o mesmo estatuto dentro da Oração. Lembramos aqui, como explicamos no capítulo 2, que as camadas são as partes que compõem os quatro níveis do Componente Gramatical (o Interpessoal, o Representacional, o Morfossintático e o Fonológico).

$\mathrm{Na}$ GDF, os elementos hierárquicos ocupam posições de acordo com um fluxo descendente, ou seja, das camadas mais altas de um nível em direção às camadas mais baixas, baseando-se em considerações de escopo. Os não hierárquicos, por sua vez, ocupam posições com base nas considerações de alinhamento. Os subitens a seguir tratarão de explicar esses dois tipos de ordenação. Porém, como nosso foco 
de análise neste trabalho são os constituintes não hierárquicos, apenas apresentaremos brevemente o sistema de ordenação hierárquico, visto que, apesar de não os analisarmos, não é possível simplesmente excluí-los dos esquemas de ordenações.

\subsubsection{Ordenação dos constituintes hierárquicos}

Os constituintes hierárquicos têm prioridade sobre os não hierárquicos para ocupar as posições absolutas periféricas e seguem o Princípio de Iconicidade. Assim, começamos colocando funções, modificadores $(\Sigma)$ e operadores ( $\pi$ ) de Movimento nas posições apropriadas e terminamos com operadores e modificadores de Propriedades Configuracionais e de EsCos. Dentro de cada grupo, as funções são expressas antes dos operadores e modificadores, uma vez que as funções são hierarquicamente superiores à unidade que escopam. Os constituintes com essas atribuições são ordenados de maneira centrípeta, ou seja, do exterior para o interior, ou em outras palavras, das posições mais extremas em direção à $\mathrm{P}^{\mathrm{M}}$. Assim, o $\Sigma$ da camada mais alta deve ser o primeiro a ser alocado e deve ocupar as posições externas à Oração (Pre e $P^{\text {pos }}$ ). Se não existir esse $\Sigma$, essa posição fica livre para ser ocupada por um modificador de uma camada mais baixa, e assim sucessivamente.

Vejamos um exemplo, tomado de Pezatti (2014, p. 81):

(2) por exemplo, em S. Vicente, isso já não acontece dessa maneira (CV95:Rapariga:76) (PEZATTI, 2014, p. 81).

A pesquisadora explica que, nesse exemplo, os termos isso e acontece são elementos configuracionais, ou seja, não hierárquicos, pois pertencem à estrutura nuclear, já que acontecer é um verbo que seleciona um argumento inativo, como isso. Esses dois constituintes, então, formam nossa base predicativa, sem que haja prioridade de um sobre o outro, e ambos pertencem à mesma camada: à Propriedade Configuracional (f) do nível Representacional. O constituinte dessa maneira serve para restringir a Propriedade Configuracional, ou seja, tem escopo sobre isso acontece, e por isso (por funcionar como um modificador da Propriedade Configuracional), deve também ser considerado não hierárquico, pois localiza-se na mesma camada do elemento que escopa. O constituinte já não é um operador (pois é 
um recurso gramatical - e não mais lexical - que especifica o núcleo) que nega o EsCo isso acontece dessa maneira (composto pela Propriedade Configuracional isso acontece e pelo modificador dessa maneira) e por isso, também é um constituinte não hierárquico. O constituinte em $\mathrm{S}$. Vicente também modifica o EsCo. Vemos aqui, portanto, que há uma hierarquia descendente: EsCos (que abarcam dois modificadores, um de modo e outro locativo, além de um operador de negação), que abarcam a Propriedade Configuracional (que abarca um operador). Além disso, o constituinte por exemplo restringe o Ato Discursivo em S. Vicente isso já não acontece dessa maneira, ao indicar seu estatuto dentro do Movimento (e lembramos que Ato Discursivo e Movimento são as camadas mais altas do Nível Interpessoal). Para tentarmos visualizar melhor as relações de escopo dos constituintes do exemplo (2) vejamos esquema a seguir: 


\section{Componente Conceitual (intenção do falante)}

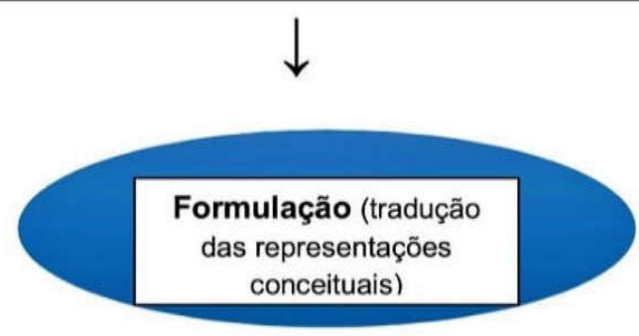

Movimento (M): por exemplo, em S. Vicente isso já não acontece dessa maneira.

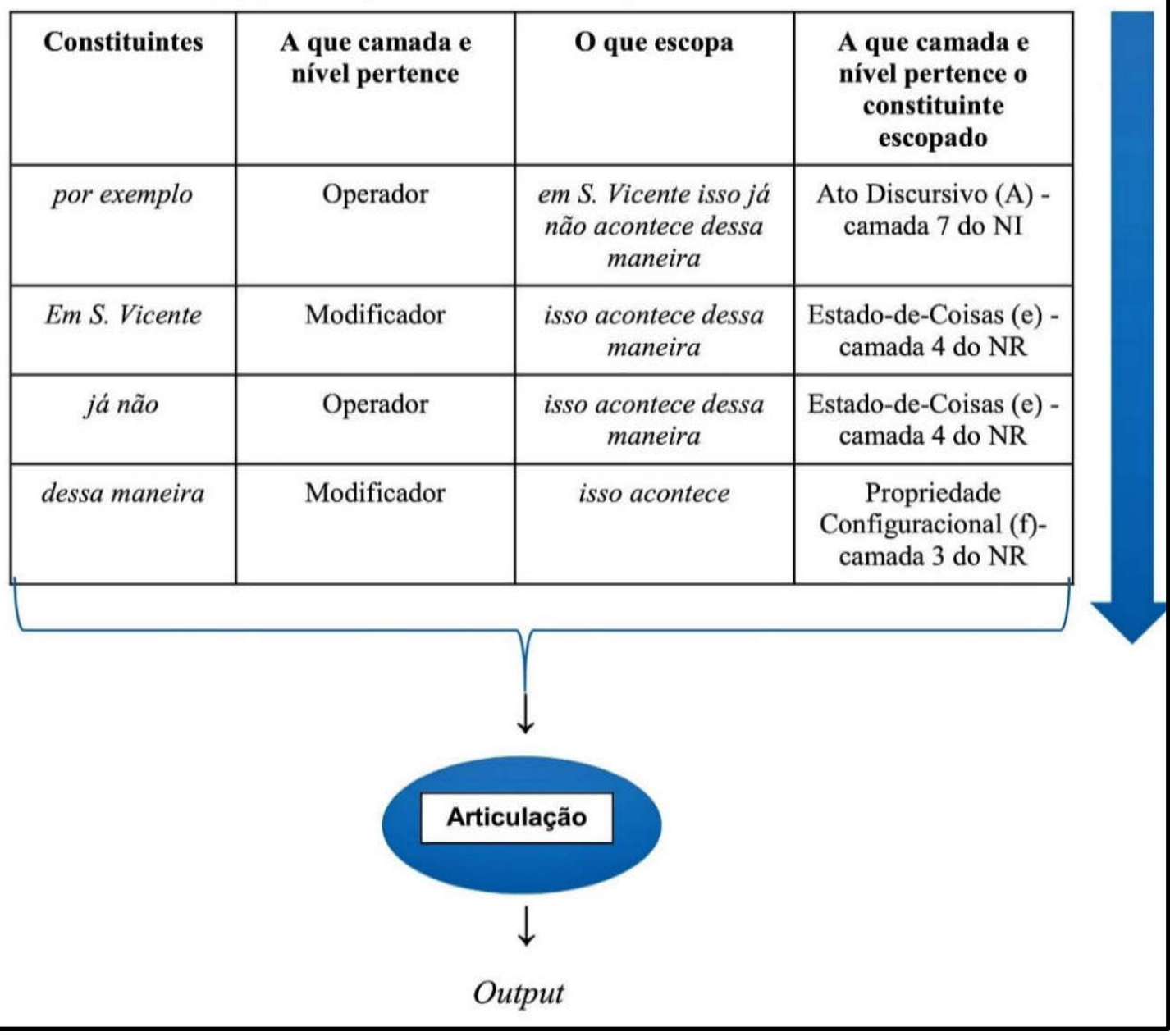

Figura 12 - Exemplo de ordenação de constituintes hierárquicos 
Vemos, portanto, que o enunciado como um todo, ou seja, o Movimento (definido, lembremos, como a menor unidade livre do discurso), constitui a camada mais alta do $\mathrm{Nl}$ e é o que se recebe no Output. Antes, porém, de chegar a esse Componente de Saída, os elementos do Componente Conceitual passaram pelo Componente Gramatical para receber formulação e codificação. Todo o processo de codificação foi influenciado pelo Componente Contextual. Dentro do Componente Gramatical, os elementos passam pelas várias camadas dos quatro níveis (NI, NR, $\mathrm{NM}$ e NF), seguindo a lógica de a pragmática (NI) comandar a semântica (NR), e esta comandar a morfossintaxe (NM), que comanda a fonologia (NF): daí o esquema descendente e hierárquico do modelo. Assim, portanto, em nosso esquema acima, todo o quadro está dentro do Componente Gramatical e as camadas, em nosso exemplo, também são descendentes, seguindo a ordem Movimento (M) - camada 8 do $\mathrm{NI} \rightarrow$ Ato Discursivo (A) - camada 7 do $\mathrm{NI} \rightarrow$ Estado-de-coisas (e) - camada 4 do NR $\rightarrow$ Propriedade Configuracional (f) - camada 3 do NR, como representamos no esquema abaixo:

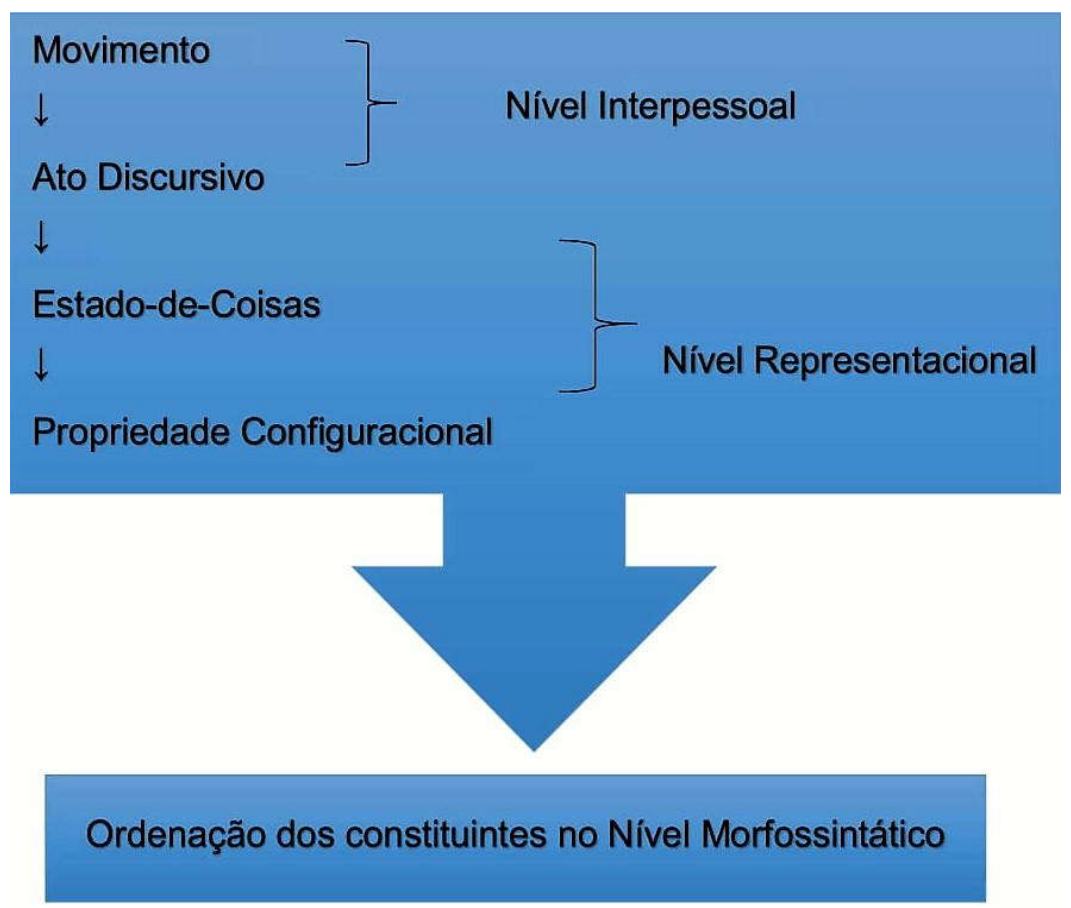

Esquema 11 - Esquema de ordenação dos constituintes 
O Nível Morfossintático (NM) abriga padrões para moldes hierárquicos e não hierárquicos, ou seja, esquemas de posições que podem ser ocupadas por constituintes. Assim, baseados nas ideias de Dik (1997), Hengeveld \& Mackenzie (2008) postulam a existência de quatro posições absolutas que podem existir nas línguas, além de posições relativas a essas quatro, chamadas de intermediárias, como mostra o esquema a seguir 74 :

\begin{tabular}{|c|c|c|c|c|c|c|c|c|c|c|}
\hline $\mathbf{P}^{\mathrm{I}}$ & $\mathbf{P}^{\mathrm{I}+1}$ & $\mathbf{P}^{\mathrm{I}+\mathrm{n}}$ & $\mathbf{P}^{\mathrm{M}-\mathrm{n}}$ & $\mathbf{P}^{\mathrm{M}-1}$ & $\mathbf{P}^{\mathrm{M}}$ & $\mathbf{P}^{\mathrm{M}+1}$ & $\mathbf{P}^{\mathrm{M}+\mathrm{n}}$ & $\mathbf{P}^{\mathrm{F}-\mathrm{n}}$ & $\mathbf{P}^{\mathrm{F}-1}$ & $\mathbf{P F}^{\mathrm{F}}$ \\
\hline
\end{tabular}

Esquema 12 - Posições absolutas e relativas dos constituintes na Oração

Todas as posições do esquema acima pertencem à camada da Oração, no NM. As três posições absolutas relevantes para nós estão representadas pelas siglas $\mathrm{P}^{\mathrm{I}}$, que indica posição inicial, $\mathrm{PM}$, indicando posição medial, e $\mathrm{PF}$, a posição final. Quando essas posições já estiverem preenchidas por algum material linguístico, as posições relativas tornam-se disponíveis, tais como $\mathrm{P}^{\mathrm{l+1}}, \mathrm{P}^{\mathrm{M}+n}$, etc. Há regras e tendências de ocupação de cada uma dessas posições nas línguas particulares, que apresentaremos a seguir.

Segundo Hengeveld \& Mackenzie (2008) e Pezatti (2014, p. 82), "As duas posições periféricas ( $\mathrm{P}^{\mathrm{I}}$ e $\left.\mathrm{P}^{\mathrm{F}}\right)$ são psicologicamente salientes [...]" e, tal como várias pesquisas em diferentes línguas têm mostrado, têm preferência para abrigar constituintes com funções pragmáticas (que, como veremos no item 3.3, a seguir, são três: Tópico, Foco e Contraste). A partir disso, Pezatti (2014) propõe que, em PB, a PI é ocupada por constituintes com função de Tópico, $\mathrm{PM}$ por constituintes hierárquicos e $\mathrm{P}^{\mathrm{F}}$ por constituintes com função de Foco. O domínio da posição medial $\left(\mathrm{P}^{\mathrm{M}}\right)$ é o menos saliente e é ocupado por constituintes não hierárquicos da Oração, ou seja, pelo predicado e seus argumentos.

Usa-se o termo domínio de uma posição para indicar que cada uma pode ainda ser subdividida em posições intermediárias. Assim, o núcleo de $\mathrm{P}^{\mathrm{M}}$ pode ser ocupado por um predicado (verbo ou locução verbal), e a partir disso, abrem-se as posições intermediárias ( $\mathrm{P}^{\mathrm{M}+1}$, por exemplo), que seriam ocupadas pelos argumentos do predicado.

\footnotetext{
${ }^{74} \mathrm{O}$ modelo da GDF prevê também a $\mathrm{P}^{2}$ e suas posições intermediárias, mas como essa posição não
} está disponível nem para o PB nem para E, não a consideramos no nosso esquema. 
No entanto, se qualquer constituinte argumental tiver função pragmática, ele não ocupará mais domínio de $\mathrm{P}^{\mathrm{M}}$, mas sim as posições periféricas, ou seja, $\mathrm{P}^{\mathrm{I}}$ ou $\mathrm{P}^{\mathrm{F}}$. Vejamos abaixo como ficaria a ordenação dos constituintes em $\mathrm{P}^{\mathrm{M}}$ :

(3) ${ }^{*}$ CAl: ô / a minha irmã comprou um laptop de dois-mil reais //. (C-ORAL-BRASIL bfamcv20).

\begin{tabular}{|c|c|c|}
\hline $\mathbf{P}^{\mathrm{I}}$ & \multicolumn{2}{|c|}{$\mathbf{P}^{\mathrm{M}}$} \\
\hline a minha irmã & comprou & um laptop de dois mil reais \\
\hline TOP & $\mathrm{PM}^{\mathrm{M}}$ & $\mathrm{PM}^{\mathrm{M}+1}$ \\
\hline
\end{tabular}

No exemplo (3), o constituinte minha irmã, apesar de ser argumental, não ocupa domínio de $\mathrm{PM}^{\mathrm{M}}$, mas sim de $\mathrm{P}^{\mathrm{I}}$, por ser o constituinte com função pragmática Tópico, como veremos em detalhes mais adiante. A PM, portanto, é preenchida pelo predicado comprou e por seu argumento com função semântica Inativo um laptop de dois mil reais.

O mesmo protocolo se aplica ao EP, como demonstramos no exemplo a seguir:

(4) *PIE: y el Madrid tiene muy buenos <jugadores> //\$ (C-ORAL-ROM-efamdl33).

[e o Madri tem muito bons jogadores]

\begin{tabular}{|c|c|c|}
\hline $\mathbf{P}^{\mathbf{I}}$ & \multicolumn{2}{|c|}{$\mathbf{P}^{\mathbf{M}}$} \\
\hline el Madrid & tiene & muy buenos jugadores \\
\hline TOP & $\mathbf{P}^{\mathbf{M}}$ & $\mathbf{P}^{\mathbf{M}+1}$ \\
\hline
\end{tabular}

A comparação entre (3) e (4) nos revela uma semelhança de posicionamento de constituintes nas duas línguas. No entanto, veremos mais adiante que em muitos casos essa semelhança não se mantém. Por enquanto, o que nos interessa aqui é 
explicar as regras de colocação propostas pelas GDF e mostrar que elas são suficientes para explicar a ordenação em ambas as línguas.

No entanto, não é necessário que as quatro posições absolutas sejam preenchidas (ou, em PB e em EP, que as três posições absolutas disponíveis sejam preenchidas). Pode, assim, existir Orações constituídas por apenas $\mathrm{PM}^{\mathrm{M}}$ e $\mathrm{PF}^{\mathrm{F}}$ ou $\mathrm{P}^{\mathrm{I}} \mathrm{e}$ $\mathrm{PM}$ ou apenas $\mathrm{PF}$, etc., como veremos no decorrer deste capítulo.

A PF pode ser ocupada por constituintes com função pragmática ou por modificadores e operadores de todas as camadas do NR, que é o que ocorre no exemplo (2) que trouxemos acima e retomamos aqui como (5):

(5) por exemplo, em S. Vicente, isso já não acontece dessa maneira (CV95:Rapariga:76) (PEZATTI, 2014, p. 81).

Nesse exemplo, o constituinte dessa maneira ocupa $\mathrm{PF}^{\mathrm{F}}$ e é um Modificador da Propriedade Configuracional (isso acontece).

Já a $\mathrm{P}^{\mathrm{I}}$, além de abrigar constituintes com função pragmática, pode também abrigar marcadores de llocução (os pronomes interrogativos, como que, qual, etc. que serão retomados na seção na qual falaremos sobre as llocuções Interrogativas), modificadores e operadores do $\mathrm{NI}$ e do NR, modificadores de Ato Discursivo e de Conteúdo Comunicado (NI) e modificadores de Conteúdo Proposicional (NR). Voltando uma vez mais ao exemplo (5), o Modificador do EsCo em S. Vicente ocupa o domínio de $\mathrm{P}^{\mathrm{I}}$, bem como o Tópico isso. Dessa maneira, (5) pode ter suas posições representadas no esquema abaixo:

\begin{tabular}{|c|c|c|c|c|c|}
\hline Ppre 75 & $\mathbf{P}^{\mathbf{l}}$ & $\mathbf{P}^{\mathbf{1 + 1}}$ & \multicolumn{2}{|c|}{$\mathbf{P M}^{\mathbf{M}}$} & $\mathbf{P F}^{\mathbf{F}}$ \\
\hline $\begin{array}{c}\text { Por } \\
\text { exemplo }\end{array}$ & $\begin{array}{c}\text { em S. } \\
\text { Vicente }\end{array}$ & isso & já não & acontece & dessa maneira \\
\hline & & & $\mathbf{P}^{\mathrm{M}-1}$ & $\mathbf{P}^{\mathrm{M}}$ & \\
\hline
\end{tabular}

Como não é nosso objetivo nesta pesquisa descrever a ordenação de todos os tipos de constituintes em PB e em EP, restringindo-nos aos configuracionais, em nossas análises muitas vezes apontaremos apenas que determinados constituintes ocupam domínio de $\mathrm{P}^{\mathrm{I}}$, ou domínio de $\mathrm{P}^{\mathrm{F}}$. Procederemos assim para que não

${ }^{75}$ Explicaremos a Pre mais adiante. 
tenhamos que especificar as posições de modificadores e operadores ou de outros constituintes, que fogem ao escopo de nossa pesquisa, mas que ocupam essas posições, talvez a mesma ocupada por constituintes com as funções que nos interessam, como ocorre no esquema de (5), em que o constituinte com função de Tópico (isso) ocupa domínio de $\mathrm{P}^{\mathrm{I}}$ (especificamente $\mathrm{P}^{\mathrm{I}+1}$ ), já que a posição absoluta de $\mathrm{P}^{\mathrm{I}}$ já está ocupada por um modificador.

O esquema de posições que representa o domínio da Oração (Pcentro) é, portanto, o seguinte (lembrando que poderiam ser abertas quantas posições intermediárias forem necessárias):

\begin{tabular}{|c|c|c|c|c|c|c|c|c|}
\hline \multicolumn{9}{|c|}{ Pcentro (Oração) } \\
\hline \multicolumn{3}{|c|}{$\mathbf{P l}^{\mathbf{l}}$} & \multicolumn{3}{|c|}{$\mathbf{P}^{\mathrm{M}}$} & \multicolumn{3}{|c|}{$\mathbf{P F}^{\mathrm{F}}$} \\
\hline $\mathrm{Pl}^{\prime}$ & $\mathrm{P}^{\mathrm{I}+1}$ & $\mathrm{P}^{1+n} \ldots$ & $\ldots P^{\mathrm{M}-1}$ & $\mathrm{PM}^{\mathrm{M}}$ & $P^{M+1} \ldots$ & $\ldots P^{\mathrm{F}-1}$ & $\mathrm{PF}$ & $\mathrm{P}^{\mathrm{F}+1} \ldots$ \\
\hline
\end{tabular}

Esquema 13 - Esquema de posições da P centro $^{-}$

No entanto, essas posições não são suficientes para abrigar todos os constituintes da língua, uma vez que os Falantes recorrem frequentemente a expressões que fazem parte da Expressão Linguística, mas que extrapolam os limites da Oração, como já comentamos anteriormente. A GDF, então, prevê mais duas posições marginais para abrigar os constituintes extraoracionais: a $\mathbf{P}^{\text {pre }}$ (para a posição pré-oracional) e a Ppos (para a posição pós-oracional). Essas posições abrigam constituintes com função retórica (Orientação, Esclarecimento, Concessão e Motivação), como veremos no capítulo 5.

Isso posto, podemos atualizar o esquema de posições previstas na GDF como indicamos abaixo:

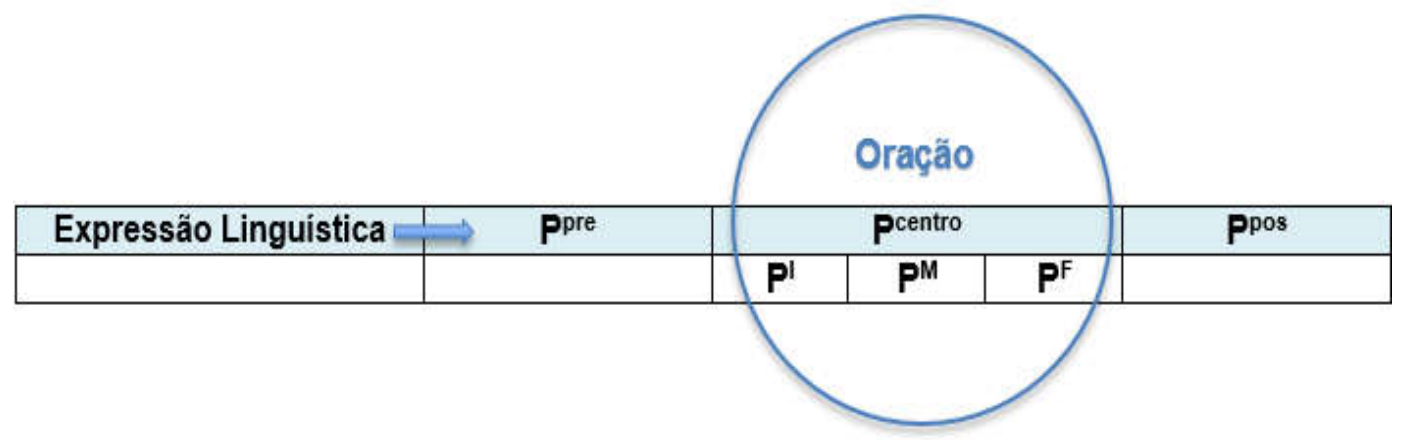


No quadro abaixo, sistematizamos quais tipos de constituintes são candidatos possíveis de ocupar cada uma das posições:

\begin{tabular}{|c|c|c|c|c|}
\hline \multicolumn{5}{|c|}{ Expressão linguística } \\
\hline \multirow[t]{2}{*}{ Ppre } & \multicolumn{3}{|c|}{ Pcentro (Oração) } & \multirow[t]{2}{*}{ Ppos } \\
\hline & $\mathbf{P}^{\prime}$ & $\mathbf{P}^{\mathrm{M}}$ & $\mathbf{P F}^{\mathrm{F}}$ & \\
\hline $\begin{array}{c}\text { Constituintes } \\
\text { hierárquicos } \\
\text { com função } \\
\text { Retórica ou } \\
\text { modificadores } \\
\text { e operadores de } \\
\text { Movimento e } \\
\text { Ato Discursivo }\end{array}$ & $\begin{array}{c}\text { Constituintes } \\
\text { hierárquicos } \\
\text { com função } \\
\text { pragmática } \\
\text { operadores do } \\
\mathrm{NI} \text { e do NR, } \\
\text { modificadores } \\
\text { de Ato e } \\
\text { Conteúdo } \\
\text { Comunicado } \\
\text { (NI) e } \\
\text { modificadores } \\
\text { de Conteúdo } \\
\text { Proposicional } \\
\text { (NR) }\end{array}$ & $\begin{array}{c}\text { Constituintes } \\
\text { não hierárquicos } \\
\text { (argumentais da } \\
\text { camada da } \\
\text { Propriedade } \\
\text { Configuracional) }\end{array}$ & $\begin{array}{c}\text { Constituintes } \\
\text { hierárquicos com } \\
\text { função } \\
\text { pragmática e } \\
\text { modificadores e } \\
\text { operadores de } \\
\text { Estados-de } \\
\text { coisas e de } \\
\text { Propriedades } \\
\text { Configuracionais } \\
\text { de todas as } \\
\text { camadas do NR. }\end{array}$ & $\begin{array}{c}\text { Constituintes } \\
\text { hierárquicos } \\
\text { com função } \\
\text { Retórica ou } \\
\text { modificadores } \\
\text { e operadores } \\
\text { de Movimento } \\
\text { e Ato } \\
\text { Discursivo. }\end{array}$ \\
\hline
\end{tabular}

A seguir, abordaremos de maneira um pouco mais detalhada a organização dos constituintes não hierárquicos, nos quais se centra nossa pesquisa.

\subsubsection{Alinhamento dos constituintes não hierárquicos}

Depois que os constituintes hierárquicos já estiverem posicionados, ocorre o alinhamento dos constituintes não hierárquicos, que, como já dissemos anteriormente, referem-se aos constituintes da Propriedade Configuracional, ou seja, ao predicado e seus argumentos.

O alinhamento refere-se a como o predicado se relaciona com seus argumentos, ou seja, aos moldes de predicação de cada língua, como explicamos no

76 Apesar de apresentarmos aqui todos os tipos de constituintes que funcionam como candidatos a ocuparem as cinco posições, os modificadores e operadores fogem do escopo de nossa pesquisa, como já explicamos anteriormente, e por isso serão retomados de maneira apenas genérica nas seções seguintes. 
capítulo 2. Esse arranjo pode se dar de maneiras diferentes nas línguas, considerando-se aspectos pragmáticos, e/ou semânticos e/ou sintáticos, sendo que, para a GDF, os aspectos sintáticos só são considerados quando há neutralização de distinções semânticas e pragmáticas. Hengeveld \& Mackenzie (2009, p.185-6) nos dizem que podemos distinguir três tipos básicos de alinhamento:

1. Alinhamento interpessoal: a organização morfossintática reflete a organização do Nível Interpessoal no que diz respeito quer às funções pragmáticas (Tópico, Foco, etc.) quer às propriedades referenciais (identificabilidade, especificidade, etc.).

2. Alinhamento representacional: a organização morfossintática reflete a organização do Nível Representacional no que diz respeito quer às funções semânticas (Ator, Paciente, etc.) quer à designação (oposição animado/inanimado, pessoa gramatical, etc.).

3. Alinhamento morfossintático: a organização morfossintática não é um espelho fiel nem da organização do Nível Interpessoal nem do Nível Representacional, exibindo, portanto, a sua própria organização. Esse nível diz respeito quer às já mencionadas funções sintáticas (Sujeito, Objeto) quer à complexidade dos constituintes (palavra, frase, oração, etc.).

A partir de tais pressupostos, podemos classificar as línguas de acordo com a organização da gramática de que dispõem; dito de outro modo: se uma gramática se organiza segundo princípios interpessoais, segundo princípios representacionais, ou, alternativamente ainda, segundo princípios morfossintáticos. O que é certo é que se trata de tendências, uma vez que, muitas vezes, as línguas podem exibir mistura de alinhamentos.

Tanto o PB como o EP mesclam os três tipos de alinhamentos, já que a ordenação de constituintes nessas línguas sofre influência tanto da pragmática, quanto da semântica e da morfossintaxe, embora acreditemos que os graus de influência de cada uma dessas esferas não sejam idênticos nas duas línguas. $O$ alinhamento representacional pode ser exemplificado pelo que abordamos no item 2.1.2.b, do capítulo 2, quando tratamos das funções semânticas na GDF.

Vimos que, em PB, a tendência é que constituintes com função Ator ocupem posições à esquerda do predicado, enquanto constituintes com funções Inativo e Locativo, ocupem posições à sua direita. Essa tendência, como também já explicamos anteriormente, pode ser alterada por fatores pragmáticos (e, nestes casos, temos um alinhamento interpessoal). Não entraremos em detalhes nesse tipo de alinhamento por enquanto, devido ao fato de não termos, ainda, explicado as funções pragmáticas. É válido assinalar, por enquanto, como já o fizemos nos exemplos (3) - a minha irmão comprou um laptop de dois mil reais - e (4) - el Madrid tiene muy buenos jugadores 
- que constituintes que ocupariam domínio de $\mathrm{PM}^{\mathrm{M}}$ podem passar a ocupar $\mathrm{PI}^{\mathrm{I}}$ ou $\mathrm{PF}^{\mathrm{F}}$. Assim, tentaremos explicar o esquema de posicionamento seguindo, na medida do possível, a sequência: constituintes que ocupam domínio de $\mathrm{P}^{\mathrm{M}}$, depois constituintes que ocupam domínio de $\mathrm{Pl}^{\mathrm{I}}$ e $\mathrm{PF}^{\mathrm{F}}$ (quando tivermos explicado as funções pragmáticas) e, por último, constituintes que ocupam domínio de Pre e Ppos (quando tivermos explicado as funções retóricas que nos interessa analisar neste trabalho).

Comecemos, portanto, pela $\mathrm{PM}$. Como já explicamos anteriormente, a primeira posição da $\mathrm{P}^{\mathrm{M}}$ a ser ocupada é seu núcleo, ou seja, a posição absoluta $\mathrm{PM}$. Os candidatos a essa posição podem ser um verbo, um nome, um adjetivo ou um advérbio. A partir daí, é possível disponibilizar as posições intermediárias ( $\mathrm{P}^{\mathrm{M}-1}, \mathrm{P}^{\mathrm{M}+1}$, $\mathrm{P}^{\mathrm{M}+2}$, etc.), ocupadas iconicamente pelos argumentos do predicado. Assim, é o Molde de predicação (de Propriedades configuracionais de predicados de um, dois e três lugares), como explicamos no capítulo 2, que determinará quantas posições intermediárias serão disponibilizadas.

A seguir, retomaremos alguns poucos exemplos que demos antes, agora para indicar o esquema de posições que cada constituinte ocupa. A escassez de exemplos aqui se deve ao fato de que é necessário explicar as funções pragmáticas e retóricas (principalmente Tópico e Foco) para que se entendam os esquemas de posições. Por isso, neste primeiro momento, só traremos alguns exemplos de Propriedades configuracionais de predicação de dois e três lugares, reservando as de um lugar para quando tivermos explicado tais funções.

(6) *MAR: aí ela deu uma folha / aí me falaram que era trabalho // aí eu nũ tinha entendido a folha / traduzi a folha toda e nũ entendi o que que era // (C-ORAL-BRASIL bpubdl11).

\begin{tabular}{|c|c|c|c|}
\hline \multicolumn{2}{|c|}{$\mathbf{P}^{\mathbf{I}}$} & $\mathbf{P M}^{\mathrm{M}}$ & $\mathrm{P}^{\mathrm{M}+1}$ \\
\hline$e u$ & não & tinha entendido & a folha \\
\hline TOP & $\mathrm{Pl}+1$ & & \\
\hline \multicolumn{2}{|c|}{ [eu] } & traduzi & a folha toda \\
\hline \multicolumn{2}{|c|}{ TOP } & & \\
\hline
\end{tabular}

(7) ${ }^{*}$ GIL: <no \&ca> + <os times antigos> // a gente nũ vai jogar um e-mail / quem quiser participar participa //a gente vai <mandar / o'> / e-mail pra / tal pessoa / <pra falar > + (CORAL-BRASIL-bfamcv01). 


\begin{tabular}{|c|c|c|c|}
\hline $\mathbf{P l}^{\mathbf{1}}$ & $\mathbf{P M}$ & $\mathbf{P}^{\mathbf{M}+1}$ & $\mathbf{P}^{\mathbf{M}+2}$ \\
\hline $\begin{array}{c}\text { a gente } \\
\text { TOP }\end{array}$ & vai mandar & o e-mail & pra tal pessoa \\
\hline
\end{tabular}

Nesses esquemas de posicionamentos, constatamos que, canonicamente ${ }^{77}$, para o tipo de Ato Discursivo que selecionamos para análise, em PB:

(i) os constituintes que ocupam posição central de $\mathrm{P}^{\mathrm{M}}$ são verbos ou locuções verbais (tinha entendido, traduzi e vai mandar);

(ii) que posições relativas à direita de $\mathrm{P}^{\mathrm{M}}$ são ocupadas por constituintes com as funções semânticas Inativo (a folha, o e-mail) ou Locativo (para tal pessoa);

(iii) que os constituintes que ocupam $\mathrm{P}^{\prime}$ (eu e a gente) acumulam três funções: sintática, semântica e pragmática, ou seja, são Sujeitos, Atores e Tópicos.

Vejamos como podemos esquematizar o posicionamento de constituintes nesses dois exemplos do EP:

(8) *DOL: vive en Las Rozas / y su teléfono es / noventa y uno / seis / treinta y seis ...\$ ésta ha hecho primaria //\$ (C-ORAL-ROM-epubdI07) (C-ORAL-ROM-epubdl07)

[Esta fez o primário]

\begin{tabular}{|c|c|c|}
\hline $\mathbf{P}^{\mathbf{I}}$ & $\mathbf{P}^{\mathbf{M}}$ & $\mathbf{P}^{\mathbf{M}+1}$ \\
\hline ésta & ha hecho & primaria \\
TOP & & \\
\hline
\end{tabular}

(9) PRI: y tiene trabajo allí el chaval / no ?\$

*NAT: hhh //\$ ahora acaba de abrir una [/] una clínica //\$ (C-ORAL-ROM-epubdl06)

77 Sempre que usamos o termo canônico estamos nos referindo à alta frequência e naturalidade das expressões, que, por isso, são tidas como não marcadas na língua. 
[e tem trabalho lá o moço, não?]

[e o moço tem trabalho lá o moço, né?]

\begin{tabular}{|c|c|c|c|c|}
\hline $\mathbf{P}^{\mathrm{M}}$ & $\mathbf{P M}^{\mathrm{M}+1}$ & $\mathbf{P}^{\mathrm{F}-1}$ & $\mathbf{P F}^{\mathrm{F}}$ & $\mathbf{P}^{\text {pos }}$ \\
\hline tiene & trabajo & alli & $\begin{array}{c}\text { el chaval } \\
\text { TOP }\end{array}$ & no \\
\hline
\end{tabular}

Embora não possamos ainda afirmar nada categoricamente em relação à comparação dos esquemas de posicionamento do PB e do EP, devido à escassez de exemplos analisados por enquanto, os dois esquemas acima já apontam para uma semelhança do EP com o PB: os constituintes que ocupam posição central de PM também são verbos ou locuções verbais (ha hecho, tiene). Também apontam para o que já havíamos constatado anteriormente: enquanto em $\mathrm{PB}$, canonicamente, Ator/Tópico ocupa $\mathrm{P}^{\mathrm{I}}$, em EP, como ocorre em (9), muito frequentemente, Ator/Tópico ocupa $\mathrm{P}^{\mathrm{F}}$, como argumentaremos no capítulo 4.

Os critérios do posicionamento dos constituintes no molde de posições previsto pela GDF podem ser assim sistematizados e resumidos: 
ESQUEMA DE PREENCHIMENTO DAS POSIÇÕES PELOS CONSTITUINTES SELECIONADOS PARA ANÁLISE

\begin{tabular}{|c|c|c|c|}
\hline $\begin{array}{l}\text { ORDEM DE } \\
\text { COLOCAÇÃO }\end{array}$ & POSIÇÕES & $\begin{array}{c}\text { TIPO DE } \\
\text { CONSTITUINTE } \\
\text { OCUPANTE }\end{array}$ & $\begin{array}{l}\text { CRITÉRIO E } \\
\text { SENTIDO DA } \\
\text { OCUPAÇÃO }\end{array}$ \\
\hline $1^{\circ}$ & $\begin{array}{c}\text { Posições absolutas } \\
\text { de Pre e Ppos }\end{array}$ & $\begin{array}{c}\text { Extraoracional com } \\
\text { funções retóricas de } \\
\text { Orientação e } \\
\text { Esclarecimento }\end{array}$ & $\begin{array}{l}\text { Relações de } \\
\text { escopo }\end{array}$ \\
\hline $2^{\circ}$ & $\begin{array}{c}\text { Posições relativas de } \\
\text { Pre e Ppos }\end{array}$ & $\begin{array}{c}\text { Extraoracional com } \\
\text { funções retóricas de } \\
\text { Orientação e } \\
\text { Esclarecimento }\end{array}$ & $\begin{array}{l}\text { Relações de } \\
\text { escopo }\end{array}$ \\
\hline $3^{\circ}$ & $\begin{array}{c}\text { Posições absolutas } \\
\text { de } \mathrm{Pl}^{\mathrm{I}} \text { e PF }\end{array}$ & $\begin{array}{l}\text { Oracional, } \\
\text { Configuracional, } \\
\text { com funções } \\
\text { pragmáticas }\end{array}$ & $\begin{array}{c}\text { Princípio de } \\
\text { Iconicidade, com } \\
\text { direção centrípeta }\end{array}$ \\
\hline $4^{\circ}$ & $\begin{array}{c}\text { Posições relativas de } \\
\text { Pl e PF }\end{array}$ & $\begin{array}{l}\text { Oracional, } \\
\text { Configuracional, } \\
\text { com funções } \\
\text { pragmáticas }\end{array}$ & $\begin{array}{c}\text { Princípio de } \\
\text { Iconicidade, com } \\
\text { direção centrípeta }\end{array}$ \\
\hline $5^{\circ}$ & $\begin{array}{c}\text { Posição absoluta de } \\
\text { PM }\end{array}$ & $\begin{array}{c}\text { Oracional, } \\
\text { Configuracional, } \\
\text { sem funções } \\
\text { pragmáticas nem } \\
\text { retóricas }\end{array}$ & $\begin{array}{c}\text { Princípio de } \\
\text { Iconicidade, com } \\
\text { direção centrífuga }\end{array}$ \\
\hline $6^{\circ}$ & $\begin{array}{c}\text { Posições relativas de } \\
\text { PM }\end{array}$ & $\begin{array}{l}\text { Oracional, } \\
\text { Configuracional, } \\
\text { sem funções } \\
\text { pragmáticas nem } \\
\text { retóricas }\end{array}$ & $\begin{array}{c}\text { Princípio de } \\
\text { Iconicidade, com } \\
\text { direção centrífuga }\end{array}$ \\
\hline
\end{tabular}

Esquema 16 - Preenchimento das posições pelos constituintes selecionados para análise 
O esquema acima pode ser ainda representado pelo seguinte vetor:

\section{VETOR DO ESQUEMA DE POSIÇÕES}

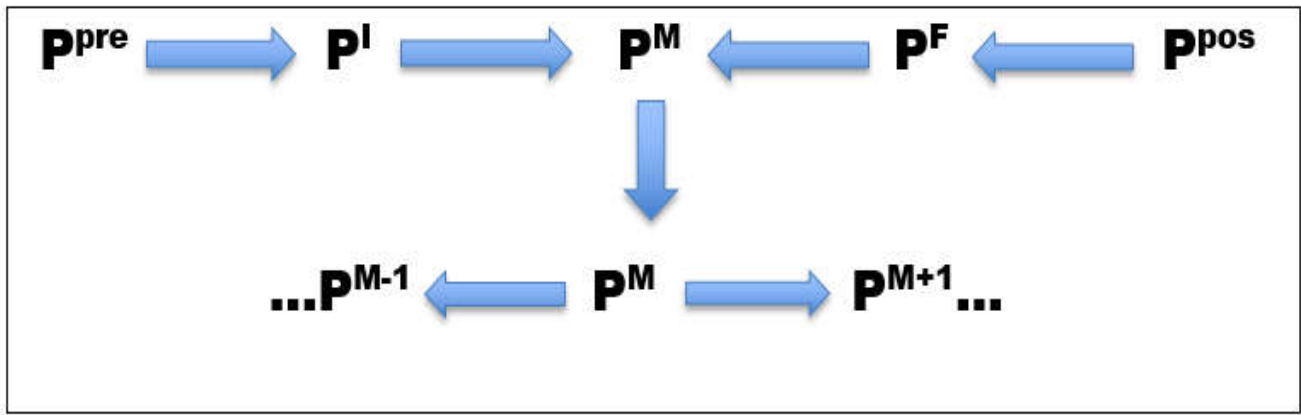

Esquema 17 - Vetor do esquema de preenchimento das posições

Já conseguimos explicar as duas primeiras funções (semânticas e sintáticas). Resta-nos explicar a terceira. Por isso, o capítulo seguinte é dedicado às funções pragmáticas. Nesses quatro primeiros capítulos (considerando o Zero), que constituíram a parte I desta tese, tentamos (i) retomar alguns dos principais estudos sobre a ordenação nas duas línguas; (ii) apresentar os projetos de onde extraímos nossos corpora e nossa metodologia; (iii) apresentar as ideias gerais da GDF e (iv) mostrar os princípios de ordenação dos constituintes a partir dessa linha teórica. Fica pendente, ainda, a descrição, nas duas línguas, dos parâmetros de ordenação dos constituintes que selecionamos para análise. Por isso, na parte II deste trabalho apresentamos os conceitos teóricos que são os centrais em nossa pesquisa (Tópico, Foco, Contraste, Orientação e Esclarecimento) e descrevemos, comparativamente, suas realizações no PB e no EP. 
PARTE II

FUNÇÕES PRAGMÁTICAS E RETÓRICAS E SUAS REALIZAÇÕES EM PB E EM EP 


\section{CAPÍTULO 4}

\section{AS FUNÇÕES PRAGMÁTICAS DE TÓPICO, FOCO E CONTRASTE}

Neste capítulo, em primeiro lugar abordaremos as três funções pragmáticas previstas pela GDF: Tópico, Foco e Contraste. Também falaremos sobre a categoria de Ênfase, para diferenciá-la de Foco e de Contraste. Em segundo lugar, trataremos de duas funções retóricas: a Orientação e o Esclarecimento, sempre comparando PB e EP.

Muito do que falaremos neste capítulo tem relação com a colocação de constituintes com função sintática de Sujeitos em $\mathrm{PF}^{\mathrm{F}}$, que se reflete em ordenações VS, OVS e VOS, ou seja, correspondem às estruturas de posposição do Sujeito em relação ao Predicado/verbo. Neste capítulo, nosso intuito é justamente mostrar as diferentes motivações para essas ordenações, argumentando que há forte influência da pragmática sobre esses parâmetros. Antecipamos, portanto, alguns resultados, para justificá-los no decorrer das três partes que compõem este capítulo, cada uma abordando uma função pragmática.

A diferença de frequência que notamos entre o PB e o EP tem uma forte representação se comparamos a quantidade dessas ordenações em nossos corpora: em EP, encontramos 114 ocorrências dos casos da chamada ordem inversa (ou seja, com Sujeitos em $\mathrm{PF}^{\mathrm{F}}$ ), com 51 tipos de verbos diferentes. Em contrapartida, em PB tivemos apenas 11 ocorrências, com 7 verbos diferentes. Colocamos esses dados em forma de gráfico, para melhor visualizá-los: 


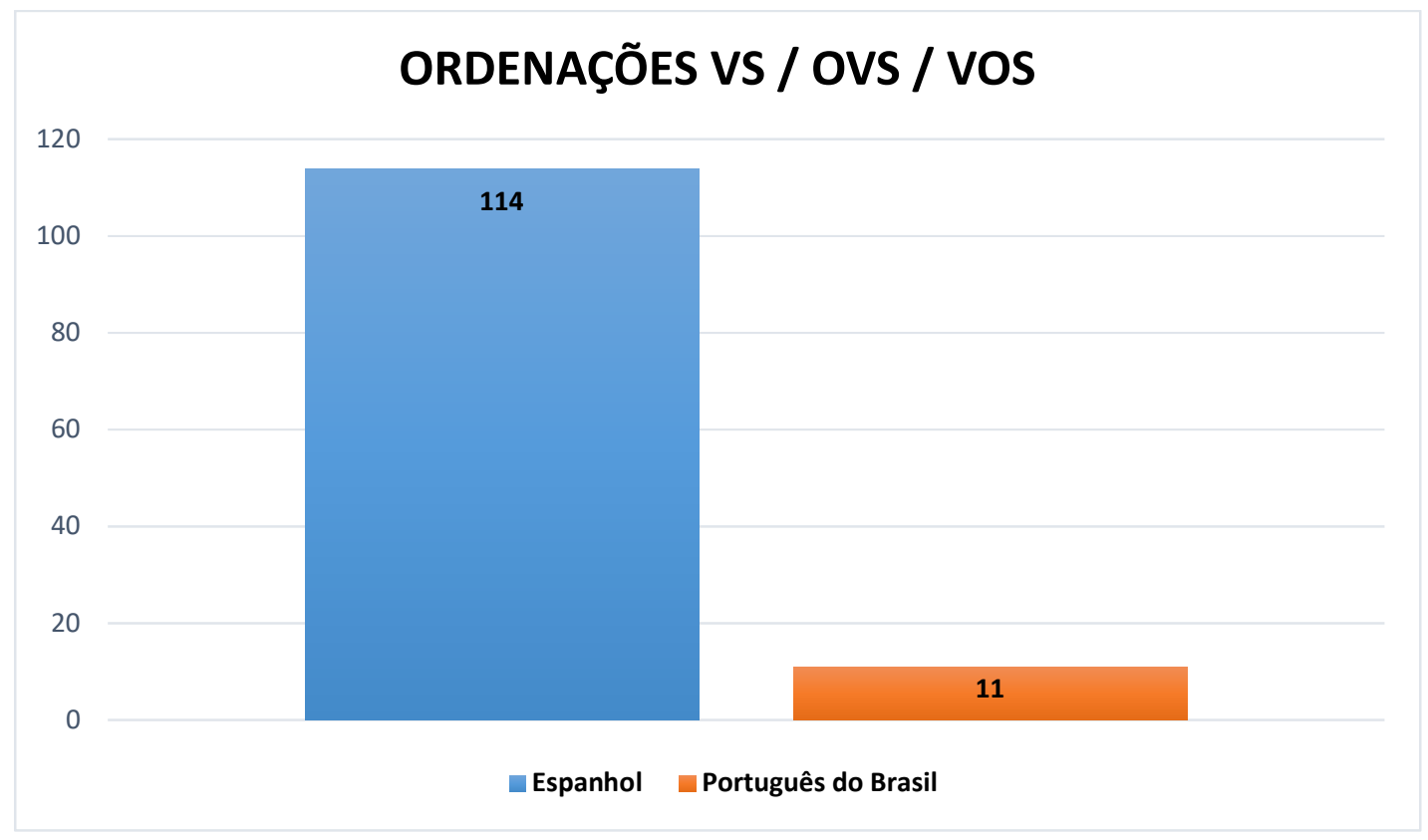

Gráfico 1 - Ocorrências ordenações VS / OVS /VOS em EP e em PB em nossos corpora

Como constatamos, em EP há uma variedade bastante grande de tipos de verbos que permitem a posposição de Sujeitos, ocorrendo em estruturas de Propriedade Configuracional de um, de dois e de três lugares, em construções Téticas, em llocuções Declarativas, Imperativas e Interrogativas. No entanto, em nosso corpus alguns verbos foram mais recorrentes: decir, estar, ir, tener, venir, ver, empezar, saber e caer. Acreditamos que há diferentes razões para os dados aqui apresentados: mais frequência de Sujeitos pospostos em EP e com uma maior variedade de verbos que em PB. Tentaremos explicá-las ao longo deste capítulo, baseando-nos nas funções pragmáticas e retóricas dessas ordenações.

Segundo Hengeveld \& Mackenzie (2008), as funções pragmáticas se localizam no Nível Interpessoal, que, como vimos, é onde são estruturados os participantes do acontecimento, a relação entre eles, o contexto e as funções informativas.

Já sabemos que o Falante recorre a diferentes estratégias para alcançar seu objetivo comunicativo. Para a GDF, as estratégias, que são intencionais, referem-se à pragmática e à retórica. Nesta seção, nos dedicaremos a explicar as funções pragmáticas e, no subitem 3.5 deste mesmo capítulo, explicaremos as funções retóricas. Nas próprias palavras de Hengeveld \& Mackenzie (2008, ps. 784-786): 
A pragmática será aqui entendida como o estudo de como os falantes moldam suas mensagens em vista de suas expectativas sobre o atual estado mental do Destinatário. Isso influencia, por exemplo, quais partes de uma unidade linguística serão apresentadas como particularmente salientes, que são escolhidas como ponto de partida do Interlocutor, e que são tomadas para serem partilhadas pelo Falante e pelo Destinatário. A influência dessas considerações sobre a estrutura das unidades linguísticas será examinada sob a rubrica de funções pragmáticas. ${ }^{78}$

Dik (1997) divide a informação pragmática em: geral (referente ao mundo, seus traços naturais e culturais, e outros mundos possíveis e imaginários), situacional (derivada da percepção e da experiência dos participantes da interação) e contextual (derivada das expressões linguísticas que ocorrem em qualquer ponto anterior ou posterior da interação verbal). Todos esses âmbitos devem ser considerados quando analisamos a influência da pragmática no Conteúdo Comunicado e seus Subatos.

Lembrando que o objetivo do Falante é ocasionar alguma mudança na informação do seu Destinatário, é preciso conhecer quais informações são novas e quais são dadas ou velhas/conhecidas por seu interlocutor. Assim, a informação dada é a que está contida na informação pragmática do parceiro de interação, e a informação nova é a que não está aí contida. Muitas vezes essas noções de dado e novo se sobrepõem e criam um continuum, por isso alguns elementos podem ao mesmo tempo ser Tópicos e Foco. Um Tópico pode ser mantido e retomado de diferentes maneiras a fim de manter a coesão do texto, por exemplo, por anáforas, por paralelismos sintáticos, etc.

Já as informações focais dizem respeito às mudanças que o usuário quer trazer à informação pragmática do Destinatário e podem ser, por exemplo, um acréscimo ou uma substituição. Por isso, são informações apresentadas como novas e relevantes para o Destinatário.

Essas escolhas mentais têm influência na estrutura das unidades linguísticas, motivadas pelas intenções, e, portanto, pela pragmática, e isso recebe o nome de função pragmática. As funções pragmáticas, portanto, constituem aspectos contextuais que trazem consequências para a forma final da Expressão Linguística,

78 Tradução nossa do original: Pragmatics will here be understood as studying how speakers mould their messages in view of their expectations of the Addressee's current state of mind. This influences, for instance, which parts of a linguistic unit will be presented as particularly salient, which are chosen as the Speaker's point of departure, and which are taken to be shared by Speaker and Addressee. The influence of these considerations upon the structure of linguistic units will be examined under the rubric of pragmatic functions. 
ou seja, constituem aspectos formais da unidade linguística que refletem seu papel na interação entre Falante e Destinatário.

A GDF reconhece três funções pragmáticas: Tópico, Foco e Contraste, que são linguisticamente marcadas de diferentes maneiras nas línguas. Em inglês, por exemplo, prefere-se marcar as funções pragmáticas por meio de recursos fonológicos, enquanto outras línguas preferem usar recursos morfossintáticos. Falaremos sobre cada uma dessas funções na sequência.

\subsection{Eso lo veo dificil x Isso eu acho difícil: a função Tópico}

O Tópico (representado pela sigla TOP) é um conceito importante para várias linhas teóricas da língua e cada uma delas, logicamente, tem-lhe dado definições e funções diferentes. Dentro da linha de cunho funcionalista, talvez uma das concepções mais conhecidas seja a de Dik (1997), para quem o Tópico é um conceito discursivo, ou, em outras palavras, é a entidade sobre a qual se fala. Para Hengeveld \& Mackenzie (2008, ps. 1331), no entanto, a função primordial do Tópico é relacionar o Conteúdo Comunicado a informações existentes no Componente Contextual. ${ }^{79}$ Assim, neste trabalho, Tópico deve ser entendido não só como o constituinte sobre o qual se predica/se comenta (porque, como veremos, essa também é uma característica dos constituintes com função de Orientação), mas também como "[...] como um reflexo linguístico de uma instrução para o Destinatário resgatar uma informação" (HENGEVELD \& MACKENZIE, 2008, ps. 1331-1334), podendo ser interpretado, portanto, como uma espécie de recurso anafórico. Essa informação a ser resgatada pode ser inferida do Supercontexto, que, como vimos no capítulo 2 , abrange diversos aspectos, tais como contexto situacional, discursivo, mental, sociocultural, físico, etc. É, portanto, um elemento identificável pelo Interlocutor, e sobre o qual se faz uma predicação, ou seja, se faz um Comentário, conforme mostra o exemplo (1):

79 No original: Topic function will be assigned to a Subact which has a special function within the Discourse Act, that of signalling how the Communicated Content relates to the gradually constructed record in the Contextual Component. The information not assigned the Topic function constitutes the Comment. 
(1) *PRI: <o Bruno tá contando uma coisa pra Janayna> // (C-ORAL-BRASIL bfamcv22).

Nesse exemplo, o constituinte o Bruno é o Tópico da enunciação, já que é o elemento conhecido tanto pelo Falante como pelo Interlocutor e sobre quem se predica. Essa é, portanto, uma informação compartilhada e que se resgata da memória. E é sobre ela que se fará um comentário: ta contando uma coisa pra Janayna. O Comentário, portanto, é a contraparte do Tópico, ou seja, enquanto o Tópico é a parte marcada (com uma função pragmática, psicologicamente saliente), o Comentário não é marcado. É justamente essa dupla funcionalidade dos Tópicos (retomar um constituinte e marcar o ponto de partida do Comentário) que faz com que, em nosso exemplo, o constituinte pra Janayna não seja considerado um Tópico, pois, apesar de ser um elemento conhecido pelos Falantes, não funciona como marco para um Comentário. A mesma justificativa se aplica a pronomes correferenciais, tanto em PB como em EP, como veremos ao longo desta seção. Tais pronomes, pelo motivo de não funcionarem como marcos discursivos, mas apenas retomarem ou anteciparem marcos discursivos, não são considerados Tópicos.

Apesar de Hengeveld \& Mackenzie (2008) não considerarem os traços de especificidade e definitude para estipular o que é Tópico, algumas pesquisas na área da GDF, e também em outras linhas teóricas, consideram que esses traços devam ser considerados como distintivos e essenciais para analisar alguns aspectos de algumas línguas, como é o caso do PB e do EP. Uma vez cumprido o requisito de o Tópico ser o resgate de uma informação, torna-se evidente que informações resgatadas/conhecidas possam ter uma forma linguística especial que contemple essa característica. Em outras palavras, há marcas morfossintáticas que revelam a especificidade/inespecificidade e determinação/indeterminação de certos constituintes, tal como vimos no capítulo 2 , quando apresentamos algumas ideias de Leonetti (1999) e Pezatti \& Fontes (2010).

Antes de continuarmos falando sobre Tópico, nos aprofundaremos nesses conceitos, já que são fundamentais para a interpretação do que são Tópico e Foco nas línguas, e para explicar características do EP, como o uso da preposição a diante de alguns tipos de argumentos, ou ainda para os inúmeros casos de duplicações, que explicaremos mais adiante. Para isso, nos apoiaremos nas ideias de Lyons (1999), Connolly (2008) e Pezatti (2010). 
Em seu livro Definiteness [Definitude], Lyons (1999) faz um extenso estudo sobre o conceito de definitude, tomando a língua inglesa como ponto de partida, mas comparando-a com diversas outras línguas. Segundo o autor, em uma visão bastante simplificada sobre o assunto, os Sintagmas indefinidos parecem ser reconhecíveis somente pelo Falante, enquanto nos definidos há um conhecimento partilhado e familiar entre Falante e Interlocutor(es). No entanto, o pesquisador argumenta que a identificabilidade parece ser um traço mais adequado que a familiaridade para estipular o que é definitude.

No que se refere aos conceitos de Tópico e Foco, que são os que nos interessam neste momento, é necessário distinguir que uma informação dada é diferente de uma informação familiar ou identificável. Um sintagma definido pode representar uma informação nova, em que o referente não tenha sido introduzido previamente, ou que não seja saliente na consciência dos participantes. Vejamos como as sentenças Téticas ${ }^{80}$ podem nos ajudar a entender essa ideia: considerando que elas são "[...] uma resposta a uma pergunta sem contexto prévio [...]" (PINHEIROCORREA, 2018, p. 234), ou seja, são emitidas em um contexto em que nenhum dos elementos mencionados é previsível, toda a informação é nova, como se o enunciado fosse "tirado do nada".

De acordo com Pinheiro-Correa $(2015,2018)$, quem, por sua vez, baseia-se em Lambrecht (1994) e em Sasse (1987, 2006), existem, universalmente, duas classes básicas de orações, diferenciadas entre si pragmaticamente por seus Moldes de Conteúdo: as Categóricas (ou Categoriais) e as Téticas (também chamadas de foco sentencial). Segundo Pinheiro-Correa (2018):

As orações categóricas têm estrutura informativa bipartida: expressam um actante e uma predicação acerca desse actante. As Téticas, por sua vez, expressam um estado de coisas ou, alternativamente, a existência de um actante (PINHEIRO-CORREA, 2018, p. 234).

Portanto, os enunciados Categoriais são bipartidos entre Tópico e Comentário, ${ }^{81}$ sendo uma atualização da informação que o Interlocutor possui, enquanto os Téticos formam uma unidade com função de Foco.

80 Pedimos desculpas aos leitores deste trabalho, por não vermos outra alternativa que não a de adiantar um assunto que ainda será tratado na seção seguinte, mas, realmente não conseguimos falar de Tópico sem falar de sentenças sem Tópico.

${ }^{81}$ Aqui, nos referimos especificamente ao espanhol e ao português, que são línguas do tipo categorial tópico-orientada. Pezatti $(2012,2014)$ fala dessa orientação para o português, mas nós acreditamos 
Suponhamos uma situação em que uma pessoa com esfoliações pelo corpo e roupa rasgada entrasse em uma loja e dissesse: o meu carro capotou. Esse enunciado veicula um EsCo, sem predicar exclusivamente sobre o carro, pois não há um elemento base para a predicação. Trata-se, portanto, de um enunciado Tético, inteiramente focal (inteiramente novo e relevante), sem Tópico. Observe-se que o artigo definido e o pronome possessivo que compõem o sintagma o meu carro remontam a uma informação definida, mas não identificável, não dada, não referencial. No entanto, se esse enunciado fosse a resposta à pergunta: o que aconteceu com seu carro?, teríamos um enunciado constituído por um Tópico (o meu carro), por ser o constituinte que carrega a informação já conhecida pelo Interlocutor e que é retomada do contexto discursivo, e por um Comentário sobre esse Tópico (capotou), que traz a informação nova.

Concluímos, portanto, que marcas morfossintáticas, como o uso artigos, de possessivos, de quantificadores, de nomes próprios, entre outros, podem funcionar como indício de topicalidade ou focalidade, mas o que, de fato, determinará essas funções é o contexto e as informações compartilhadas ou não entre os participantes da situação discursiva. Isso é o que vai diferenciar os exemplos que trazemos a seguir:82

El eclipse total sólo se pudo disfrutar en El Calafate (CLARÍN, 11/07/2010).

[O eclipse total só pôde ser desfrutado em El Calafate]. ${ }^{83}$

O autor explica que essa notícia foi publicada um dia após esta outra:

Desde el sur de la cordillera se verá mañana un eclipse total (CLARÍN, 10/07/2010).

[No sul da cordilheira, amanhã será visto um eclipse total].

que ela pode, perfeitamente, ser estendida ao E. No entanto, outras línguas podem ser do tipo categorial foco-orientada. Isso equivale a dizer que, de maneira geral, as construções categoriais não são aquelas formadas necessariamente pela sequência Tópico + Comentário, mas sim por qualquer combinação em que haja ao menos um Tópico ou um Foco que não seja um foco sentencial.

82 Os exemplos (2) e (3) são manchetes de dois jornais brasileiros e dois argentinos, tomados de um estudo de Pinheiro-Correa (2018), o qual retomaremos na seção sobre o Foco.

${ }^{83}$ Para as manchetes em questão, nós mantivemos as traduções propostas por Pinheiro-Correa (2018). 
Ao analisar (2), Pinheiro-Correa (2018) explica que o eclipse já é tido como algo sabido, como um elemento dado, e que isso se manifesta sintaticamente pela presença do artigo definido (el), determinando o sintagma. Além disso, aparece no início da sentença e tem a função de sujeito tópico. Em contrapartida, em (3) o sintagma que se refere a esse mesmo evento aparece antecedido por um artigo indefinido (un) e ocupa uma posição final na sentença (un eclipse total), indicando que se trata de uma informação não pressuposta, nova, e que, portanto, não se trata de um Sujeito Tópico.

Gostaríamos de acrescentar à análise de Pinheiro-Correa (2018) que, caso houvesse uma manchete como a que aparece em (4), a seguir, criada por nós com intuito de comparação, o constituinte Un eclipse total, segundo a interpretação do pesquisador, com a qual concordamos, não seria considerado um Tópico e toda a sentença seria focal, isto é, carregaria uma informação completamente nova, sem nenhuma parte pressuposta. Teríamos, portanto, uma sentença Tética, sem Tópico ${ }^{84}$.

\section{Un eclipse total podrá ser observado en El Calafate.}

[Um eclipse total poderá ser observado em El Calafete].

Veremos, na seção seguinte, ao falarmos sobre as sentenças Téticas, outras estratégias disponíveis em PB e em EP para a não realização do Tópico. Por ora, o que nos interessa aqui é mostrar a importância dos traços de determinação e especificidade para ambas as línguas, como se pode notar inclusive pelas traduções ao PB dos exemplos em EP.

Para darmos mais um exemplo, analisemos esse grupo de sentenças (5), criadas por nós:

A dona Dulce chegou.

Chegou a dona Dulce.

Uma senhora chegou.

Chegou uma senhora.

${ }^{84}$ Nós explicaremos melhor as sentenças Téticas no próximo subitem deste capítulo, quando falarmos sobre a função pragmática de Foco. Mas, como não é possível dissociar essa discussão do que estamos defendendo aqui, que é a possibilidade de posicionamento de TOP em uma posição diferente de PI, no PB, vimos a necessidade de adiantar o conceito de Foco da GDF: o Foco é uma instrução de atualização do Destinatário, é a informação nova relativamente mais importante ou saliente num dado contexto de interação verbal. 
(5e) Aquela senhora chegou.

(5f) Chegou aquela senhora.

(5g) A encomenda chegou.

(5h) Chegou a encomenda.

(5i) Uma encomenda chegou.

(5j) Chegou uma encomenda.

O uso de um artigo definido seguido de um nome próprio, em (5a) e (5b) indica que esse seja o constituinte que carregue a parte conhecida pelos participantes do discurso (identifica-se o referente de $A$ dona Dulce). Tanto é assim que, se alguma dessas sentenças fosse enunciada sem contexto prévio e sem que o Interlocutor conhecesse seu referente, provavelmente ele perguntaria algo como Quem é dona Dulce? Em (5a) e (5b), portanto, o constituinte definido e especificado é o Tópico da Oração, podendo aparecer tanto em $\mathrm{Pl}^{\mathrm{I}}$ como em $\mathrm{PF}$.

O mesmo raciocínio se aplica a (5e) e (5f), já que o determinante aquela pressupõe um conhecimento prévio sobre o referente e, por isso, em ambas, o constituinte aquela senhora também é o Tópico. Observemos que os traços [+animado] e [+humano] não interferem na atribuição dessa função pragmática, já que, igualmente $(5 \mathrm{~g})$ e $(5 \mathrm{~h})$ têm Tópicos (a encomenda). Assim, somente as construções (5c), (5d), (5i) e (5j) são, em primeira instância, desprovidas de Tópicos (são, portanto, sentenças Téticas).

Dizemos em primeira instância, pois essas marcas morfossintáticas servem apenas como índices para expressar as informações novas ou pressupostas/conhecidas pelos participantes do discurso, mas é o contexto da situação comunicativa que determinará se de fato trata-se de Tópico ou não (daí a importância de, em nossas análises, sempre considerar usos reais da língua, em situações concretas, e considerando os contextos em que ocorrem).

Essa relação entre o traço [+determinado] e o Tópico que fomos mostrando aqui também tem embasamento em estudos sobre os nomes nus, ${ }^{85} \mathrm{ou}$, em espanhol, singulares y plurales escuetos, que serão definidos na sequência. Segundo González (2014), este tema ainda é pouco estudado a partir de uma perspectiva comparada entre o PB e o EP, por isso, e por entendermos que se trata de uma questão central para a definição de Tópico que adotamos aqui, nos demoraremos um pouco nele.

${ }^{85}$ Sobre esse assunto, podem ser consultadas as pesquisas de Müller $(2003,2004)$. 
De acordo com González (2014), estudar comparativamente questões relacionadas à genericidade e à especificidade no PB e no EP é um grande desafio, já que elas envolvem inúmeros fatores e motivações:

De forma geral, os diversos trabalhos que estudam este tema lidam, dependendo do referencial teórico em que se inscrevem, não com fatores únicos, como presença vs. ausência de artigo diante de um nome, mas com um conjunto de variáveis relacionadas ora com a natureza semântica dos substantivos determinados ou não (contínuos/não contáveis vs. descontínuos/contáveis, por exemplo, conceitos que explicaremos em 1), ora com a função sintática que desempenham esses sintagmas num enunciado (sujeitos, complementos verbais) e com sua posição em relação ao verbo, e outras vezes, ainda, com seu caráter tópico, que os coloca em posição externa ao enunciado, entre outras coisas (GONZÁLEZ, 2014, p. 115)

Como viemos delineando anteriormente, entre todas essas possibilidades de fatores a serem considerados, nos interessa particularmente a relação entre topicidade e genericidade / especificidade.

Em PB, os nomes no singular e sem determinantes (nomes nus) representam uma das maneiras de marcar genericidade, ou seja, de representar toda uma classe ou conjunto de seres. "São denominados nomes nus aqueles nomes ou sintagmas que aparecem nas sentenças sem determinante explícito" (MARTINS \& BORGES, 2015, p. 455). Sentenças com nomes nus "[...] parecem conduzir a um certo grau de 'sedimentação das categorias em protótipos e em estereótipos', socialmente compartilhados" (MONDADA \& DUBOIS, 2003 apud GONZÁLEZ, 2014, p. 124)

Martins \& Borges (2015), assim como González (2014), trazem, ao longo de seus textos, vários exemplos de enunciados genéricos, dos quais selecionamos 3 para dizer que em (6) e em (7) os termos brasileiro e mulher são usados de maneira genérica e por isso podem ser expressos por um nome nu (sem determinantes, portanto). Já (8) não admite um nome nu, pois o termo mulher não está sendo usado de maneira genérica, pois é o Sujeito de uma sentença episódica e tem leitura específica.

(6) Brasileiro deixa tudo pra última hora.

(7) Mulher adora maquiagem.

(8) *Mulher comprou roupa naquela loja. 
Adaptando a constatação de Martins \& Borges (2015) ao que discutimos aqui e aos termos da GDF, interpretamos que os nomes nus de (6) e (7) não podem funcionar como Tópicos. Assim, as duas sentenças são inteiramente focais, ou seja, são Téticas. Já em (8), o termo mulher é o Tópico da Oração e, por isso, exige uma determinação. Assim, nomes nus, segundo esse ponto de vista, não podem ser Tópicos. González (2014) nos chama a atenção para o fato de que sentenças com nomes nus, em ambas as línguas, só são coerentes com verbos no presente do indicativo, já que mudar o tempo do verbo significaria produzir um enunciado episódico, que exigiria, portanto, um Tópico, ou seja, um nome não nu. É por isso que (8) é tida como agramatical no PB: o pretérito do verbo indica um episódio, e por isso não admite o nome nu como Sujeito/Tópico.

Müller (2004, apud GONZÁLEZ, 2014) já abordava em seus trabalhos a impossibilidade de que esses singulares nus em PB desempenhassem a função de Sujeito (aparente) em enunciados episódicos, como (8). Como vimos que, em PB, muito frequentemente os Sujeitos são Tópicos, nós reinterpretamos a análise proposta por Müller pela seguinte: a impossibilidade não é exatamente que singulares nus sejam Sujeitos, mas sim que sejam Tópicos.

Ainda para explicar a relação entre nomes nus e tempos verbais, González (2014) recupera o exemplo (9a), dado por Müller (2003, p. 159, apud GONZÁLEZ, 2014, p. 122) e que poderia ser reformulada como (9b) e (9c), todas podendo ser interpretadas como sentenças genéricas, ${ }^{86}$ e as compara com (9d), tida como agramatical:

Cachorro precisa de carinho. Cachorros precisam de carinho. Os cachorros precisam de carinho. ${ }^{*}$ Cachorros precisavam/precisaram de carinho.

${ }^{86}$ Segundo nossa interpretação, (9c) pode ou não ser genérica, já que a presença do determinante pode servir para recuperar um Tópico enunciado anteriormente: fala-se de determinados cachorros, especificamente, e não necessariamente à classe canina como um todo. Isso mostra, novamente, que a presença dos determinantes não é o fator primordial para diferenciar sentenças categoriais $\mathrm{e}$ episódicas (com Tópico) daquelas genéricas ou Téticas (sem Tópico), porque deve-se considerar os contextos de enunciação e as informações compartilhadas entre os seus Participantes. No entanto, a ausência dos determinantes sim, parece ser um indicativo de genericidade e, portanto, uma das marcas de sentenças Téticas. 
González (2014, p. 122) compara as sentenças de (9) com a única possibilidade de tradução ao EP, que reproduzimos abaixo:

Los perros necesitan cariño.

Baseando-se nas ideias de Laca (1999), González (2014) conclui que "[...] o emprego de singulares sem determinante em função de sujeito seria possível somente no âmbito da fraseologia (ditados, expressões idiomáticas), como em Perro que ladra no muerde 87 " (GONZÁLEZ, 2014, p. 122). Essa única possibilidade de expressar um enunciado genérico em $\mathrm{E}$, que equivale a três possibilidades em $\mathrm{PB}$, nos mostra que, claramente, existe uma diferença referente à questão dos nomes nus nas duas línguas. Essa diferença é evidente também em muitos outros exemplos trazidos pela pesquisadora, principalmente quando se analisam enunciados produzidos por aprendizes brasileiros de ELE (espanhol como língua estrangeira): González (2014) constata que muitas vezes se reproduz, na língua estrangeira, o parâmetro do PB, em sentenças que não seriam produzidas por hispanoparlantes, como em Vino es caro, por eso no tomo ou Libro aquí en Brasil es muy caro.

González (2014) também aponta uma construção bastante típica do E, não só em refrãos ou ditos populares, mas também em contextos conversacionais coloquiais, em que o Falante usa um Sujeito que parece referir-se a uma terceira pessoa (no singular ou no plural), mas com o verbo na primeira pessoa do plural, como ocorre em (11), exemplo que tomamos da autora:

Las madres somos todas iguales.

Segundo Zoppi Fontana, 2004 (apud GONZÁLEZ, 2014), essa é uma estratégia para apagar diferenças materiais entre as distintas posições sociais, ou seja, de evitar segregação entre classes: o Falante, ao usar o recurso de (11), se integra ao grupo das mães. A tradução mais provável, num estilo mais coloquial, proposta por González (2014) para a sentença (11) é a seguinte:

Mãe é tudo igual.

${ }^{87}$ Perro que ladra no muerde poderia ser traduzida ao PB por cachorro que ladra/late não morde. 
Como já dissemos, dentre todas as questões suscitadas por essas diferentes realizações dos nomes nus em PB e E, que vão muito além das que suscintamente apresentamos aqui, o que nos interessa neste momento é a compreensão da função pragmática Tópico. Assim, concluímos que as sentenças 6, 7, 9 (a, b, c), 10, 11 e 12, apesar de usarem estratégias diferentes, são todas desprovidas de constituintes com função de Tópico, ou seja, são todos exemplos de sentenças Téticas. Todos esses exemplos nos mostram claramente que Sujeito e Tópico são categorias distintas, já que em todas elas temos Sujeitos (brasileiro, mulher, (os)cachorro(s), los perros, mãe e las madres), mas nenhum deles desempenha a função de Tópico.

O exemplo (11) traz à tona, ainda, uma outra questão central na nossa pesquisa: o constituinte las madres, que como vimos tem função de Sujeito, tem uma finalidade discursiva bastante evidente, de inclusão, como dissemos anteriormente, ou seja, de mostrar que um indivíduo pertence a um grupo. Diríamos até, que tem uma função de demostrar empatia e solidariedade. O Sujeito pré-verbal, portanto, não está sendo usado de maneira neutra ou não marcada, como se costuma afirmar para sentenças com ordenações SVO. Isso vem ao encontro da nossa tese central neste trabalho e que ainda trataremos de argumentar em diversas ocasiões: o $E$ tende a não topicalizar seus Sujeitos. Uma das maneiras de destopicalizá-los é alocando-os em $\mathrm{PF}$, como citamos no início deste capítulo e como mostraremos detalhadamente mais adiante. Outra, como vimos agora, é mantê-lo em uma posição inicial da sentença ${ }^{88}$ mas com sentido genérico.

Assumimos, assim, uma interpretação um pouco diferente para a função de Tópico daquela defendida por outras vertentes teóricas e mesmo pela GDF. Nessa outra perspectiva que não a nossa, usa-se como critério para diferenciar sentenças com Tópico de sentenças sem Tópico basicamente duas variantes: (i) o tipo de verbo (ou o Molde de predicação, na GDF), considerando que somente verbos monoargumentais ou Propriedade Configuracional de um lugar podem ser desprovidas de Tópico; (ii) o arranjo de ordenação dos constituintes, considerando que somente sentenças com a ordem VS podem ser desprovidas de Tópico. Nós

\footnotetext{
88 Não nos referimos aqui à $\mathrm{P}^{\prime}$, já que interpretamos que essas sentenças Téticas estão alocadas inteiramente em domínio de $\mathrm{PF}$, por serem inteiramente focais, como mostraremos mais detalhadamente na próxima seção. Assim, em (11), por exemplo, o constituinte las madres ocuparia $\mathrm{P}^{\mathrm{F}-1}$. Quando dizemos, portanto, que esses constituintes ocupam uma posição inicial nestes casos de sentenças Téticas, significa simplesmente que ocupam uma posição à esquerda do Predicado, correspondente à ordem SVO.
} 
continuaremos argumentando, no entanto, que isso seria sobrepor categorias do Nível Morfossintático a categorias do Nível Interpessoal (que, como lembramos é o nível das representações pragmáticas), o que iria em direção contrária à proposta Topdown da GDF, como explicamos no capítulo 2, em que a pragmática comanda a semântica, que comanda a sintaxe, que comanda a fonologia. Seguimos, desse modo, na defesa de que:

Qualquer abordagem de língua que merece o epíteto 'funcional' tem levar em consideração não somente os recursos lexicais, morfossintáticos e semânticos disponíveis no sistema linguístico, mas também os modos pelos quais esses recursos podem ser usados para o propósito da comunicação. Um fato importante sobre comunicação é que ela sempre ocorre em um contexto; [...] (CONNOLLY, 2007, p.11)..$^{89}$

Voltando ao exemplo (1), apresentado antes, vemos que ele nos mostra, ainda, que a estrutura Tópico-Comentário é a menos marcada em PB, pois segue a estrutura sintática do que tradicionalmente se denomina ordem SVO, ou seja, ordem direta, sem inversões. Em PB, portanto, como já apontamos no capítulo 3, é frequente que o constituinte que exerce a função sintática de Sujeito coincida com o que desempenha a função pragmática de Tópico.

Embora muito frequente, essa coincidência entre Sujeito e Tópico em PB nem sempre ocorre e, portanto, não pode ser tomada como regra, como podemos ver no seguinte exemplo:

(13) ELI: uhn / é // na verdade /o'// fluência oral a gente nũ avalia no [/1] no homework // né // a gente avalia na [/1] nas aulas // (C-ORAL-BRASIL-bpubdl08)

O exemplo (13) nos mostra uma estratégia da Falante em preferir não deixar o termo fluência oral no domínio de $\mathrm{PM}$, como apareceria em sua forma não marcada (em uma Oração como A gente não avalia fluência oral no homework, em que fluência oral exerceria a função semântica de Inativo e sintática de Objeto). Ao invés disso, ela opta por colocar esse constituinte em $\mathrm{P}^{\mathrm{I}}$, para dar-lhe relevo pragmático, sendo que, no caso, sua intenção era retomar o marco de referência do discurso, já que o tema

89 Tradução nossa do original: Any approach to language that merits the epithet 'functional' has to take into account not only the lexical, morphosyntactic and semantic resources afforded by the language system, but also the ways in which those resources may be deployed for the purposes of communication. An important fact about communication is that it always takes place in a contexto; [...] 
do diálogo entre eles (a coordenadora pedagógica de uma escola e um professor) é justamente as tarefas e habilidades das aulas de inglês. Temos, portanto, um caso de construção com dois Tópicos: fluência oral, sendo apenas o Tópico da Oração, e a gente sendo Tópico e também Sujeito. Como um constituinte com função diferente de Sujeito é o TOP também, a sentença é considerada marcada/não icônica (ordem OSV, do ponto de vista de outras abordagens gramaticais).

A ordem SVO poderia ser representada, na GDF, com o Sujeito/Tópico ocupando $\mathrm{P}^{\mathrm{I}}$, o predicado/verbo ocupando o centro de $\mathrm{PM}^{\mathrm{M}}$ e os argumentos (no nosso exemplo, um constituinte com função semântica Inativo: fluência oral) ocupando as posições relativas de $\mathrm{P}^{\mathrm{M}}$.

Os quadros seguintes apresentam essas reflexões de maneira sintetizada:

ORDEM NÃO MARCADA EM PB:

\begin{tabular}{|l|c|c|c|c|c|}
\hline Constituinte & A gente & não & avalia91 & fluência oral & $\begin{array}{c}\text { no } \\
\text { homework }^{92}\end{array}$ \\
\hline Função Semântica & Ator & ---- & --- & Inativo & --- \\
\hline Função Sintática & Sujeito & ---- & ---- & Objeto & ---- \\
\hline Função Pragmática & TOP & ---- & --- & --- & --- \\
\hline Posição que ocupa & $\mathrm{Pl}$ & $\mathrm{PM}-1$ & $\mathrm{PM}$ & $\mathrm{PM}+1$ & $\mathrm{PF}$ \\
\hline
\end{tabular}

Esquema 18 - Ordem não marcada em PB

ORDEM MARCADA EM PB (INVERTIDA):

\begin{tabular}{|l|c|c|c|c|c|}
\hline Constituinte & $\begin{array}{c}\text { fluência } \\
\text { oral }\end{array}$ & a gente & não & avalia & $\begin{array}{c}\text { no } \\
\text { homework }\end{array}$ \\
\hline Função Semântica & Inativo & Ator & ---- & --- & --- \\
\hline Função Sintática & Objeto & Sujeito & ---- & ---- & ---- \\
\hline Função Pragmática & TOP & TOP & ---- & ---- & ---- \\
\hline Posição que ocupa & $\mathrm{P}^{\mathrm{l}}$ & $\mathrm{P}^{\mathrm{l}+1}$ & $\mathrm{P}^{\mathrm{M}-1}$ & $\mathrm{PM}$ & $\mathrm{P}^{\mathrm{F}}$ \\
\hline
\end{tabular}

Esquema 19 - Ordem marcada em $P B$

90 Do ponto de vista da GDF, o constituinte não não tem função sintática, já que, como vimos, a GDF só prevê duas funções sintáticas: Sujeito e Objeto.

91 Lembramos que, para a GDF, os verbos compõem um tipo de Predicado (verbal) e, por serem elementos nucleares, não apresentam funções semânticas, sintáticas ou pragmáticas.

${ }^{92} \mathrm{O}$ constituinte no homework é um modificador semântico que indica Locação, e não compõe nossa análise. 
Como vemos, o exemplo (13) deixa evidente que é perfeitamente possível que mais de um constituinte desempenhe a função de TOP em PB.

Ao analisar textos de corpora orais em português, Pezatti (2014) concluiu que a função pragmática de Tópico sempre ocupa o domínio da $\mathrm{P}^{\mathrm{I}}$, dentre as três posições absolutas disponíveis na língua ( $\mathrm{P}^{\mathrm{I}}, \mathrm{P}^{\mathrm{M}}$ e $\left.\mathrm{P}^{\mathrm{F}}\right)$, argumentando que exemplos como (1) e (2), em que constituintes com função de Tópico ocupam $\mathrm{P}^{\mathrm{I}}$, são a única possibilidade para marcação dessa função em Português. Nós concordamos em que, de fato, há uma forte tendência a que TOP ocupe $\mathrm{P}^{\mathrm{I}}$ em $\mathrm{PB}$, mas ressaltamos que, diferentemente da pesquisadora, acreditamos que isso seja uma tendência, com grau bastante elevado de frequência, mas não uma regra absoluta, de acordo com a interpretação que fizemos de algumas ocorrências em nosso corpus, como tentaremos mostrar com os exemplos a seguir.

(14) *MAR: <mas / \&he> + eu queria que cê me desse uma orientação aí / porque eu sei que / \&he / \&he / se foi /1 foi culpa minha também / o fato d' eu \&te + \&fico /1 virou uma bolha de /2 bola de neve / essas atividades / <né> // ${ }^{*}$ ELI: <hum hum> // (C-ORAL-BRASIL-bpubdl08)

O contexto de (14) é o mesmo que explicamos em (13): a coordenadora pedagógica e um professor conversando sobre as atividades das aulas de inglês. Fica claro, portanto, que o constituinte essas atividades já é conhecido pelos Falantes e retomado do contexto conversacional. É, portanto, um constituinte que carrega a informação compartilhada entre a coordenadora e o professor e funciona como anáfora discursiva. Retomamos e repetimos aqui a definição de Tópico que trouxemos no início desta seção: para Hengeveld \& Mackenzie (2008, ps. 1331) a função primordial do Tópico é relacionar o Conteúdo Comunicado a informações existentes no Componente Contextual. Assim, para a GDF, o Tópico é "[...] entendido como um reflexo linguístico de uma instrução para o Destinatário resgatar uma informação" (HENGEVELD \& MACKENZIE, 2008, ps. 1331-1334), podendo ser interpretado, portanto, como uma espécie de recurso anafórico. Parece-nos, portanto, que em (14), o constituinte essas atividades desempenha claramente a função pragmática de Tópico da Oração. No entanto, como vemos, ele não está ocupando PI da Oração.

Para autores como Kato (1989) e Pezatti (2012, 2014), ocorrências como (14) seriam sentenças Téticas, ou seja, inteiramente focais, já que o constituinte com função de Sujeito não é o Tópico da Oração. De acordo com Pezatti $(2012,2014)$, 
esse constituinte ocuparia $\mathrm{P}^{\mathrm{F}}$ (na verdade, segundo a pesquisadora, toda a sentença ocuparia $\mathrm{PF}^{\mathrm{F}}$ ). Assim, todo enunciado que corresponda à ordem VS, segundo essa perspectiva, é Tético. Nós acreditamos, porém, junto com Pinheiro-Correa (2015, 2018), que essa perspectiva restringe as construções Téticas às construções de Propriedade Configuracional de predicação zero e de um lugar, ou seja, aquelas que, como vimos no capítulo 2, contêm verbos intransitivos ou monoargumentais. Como exemplos desse tipo de sentenças, Pezatti (2012) cita sentenças como começou a relampejar e aconteceram vinte e um, vinte e uma erupção.

No entanto, como dissemos anteriormente, defenderemos, com autores como Pinheiro-Correa (2015, 2018) e Martínez Caro (2008), e baseando-nos em outros estudos que não tratam exatamente sobre esse tema mas que são essenciais, segundo nossa interpretação, para entendê-lo, como é o caso dos estudos de González (2014) aos quais nos referimos anteriormente, que a Propriedade Configuracional não é o fator que determina se uma sentença é ou não Tética.

Pensamos que essa decisão teórica vai ao encontro do que a própria GDF preconiza: a supremacia da Pragmática sobre a Semântica e a Sintaxe. Por isso, nossa proposta de análise para (14) é a seguinte:

\begin{tabular}{|c|c|c|c|}
\hline $\mathbf{P}^{\mathrm{M}}$ & $\mathbf{P}^{\mathrm{M}+1}$ & $\mathbf{P}^{\mathrm{F}}$ & $\mathbf{P}^{\mathrm{pos}}$ \\
\hline virou & uma bola de neve & essas atividades & né \\
\hline
\end{tabular}

Propomos que o constituinte essas atividades, por ser o Tópico, ocupe $\mathrm{PF}$, seguindo a proposta da GDF, de que $\mathrm{P}^{\mathrm{I}}$ e $\mathrm{P}^{\mathrm{F}}$ são posições que abrigam constituintes com funções especiais.

Vejamos mais um exemplo em que, segundo nossa interpretação, TOP ocupa $\mathrm{PF}$. O contexto é o seguinte: um professor e uma professora estão conversando sobre dois concursos para docentes em uma universidade. Eles dizem que, para uma das vagas, já há dois fortes candidatos que provavelmente serão os aprovados (Ronan e Giovana). O constituinte essa aí, portanto, refere-se a essa vaga (outra vez, sendo a parte de informação compartilhada entre os Falantes e retomada do contexto) e é o Tópico, ocupando PF da Oração. 
*LAU: <tem o Ronan> / e tem a / <Giovana > //

*LUZ: e tem a Giovana // [82] <então> vai ser muito disputada / essa aí //

*LAU: é // (C-ORA-BRASIL-bfamdI03)

Portanto, em (15), temos novamente uma ordem VS que, segundo o que defendemos, não constitui uma sentença Tética. ${ }^{93}$ Percebemos, portanto, que em PB a ordem VS não ocorre apenas com predicados monoargumentais, já que virar, no sentido de transforma-se, como ocorre em (14), rege dois argumentos. Sendo assim, o posicionamento de Tópico em $\mathrm{P}^{\mathrm{F}}$ (ou, melhor dito, fora de $\mathrm{P}^{\mathrm{l}}$ ) não se restringe a Propriedades configuracionais de zero e de um lugar. Além disso, o tipo de dinamicidade do EsCo não parece ser um fator determinante, já que em (14) temos um EsCo [+dinâmico], pois há uma transformação, uma mudança, enquanto em 15 e em (4) - Un eclipse total podrá ser observado en El Calafate - temos EsCos [dinâmicos], construídos com um verbo de cópula. A função semântica do Tópico também não parece ser determinante. Embora (14) e (15) tenham Sujeitos/Tópicos com função semântica de Inativo, isso não ocorre em (16), como mostramos a seguir:

(16) *ANC: <nũ pode nem mexer> direito / ela queria sair // queria ir no shopping / mostrar os peito // botou um decote em vê / com aquele sutiã horroroso que eles colocam de [/1] <de pós-operatório> / foi ela lá pro shopping // (C-ORAL-BRASIL-bfamcv20)

No exemplo acima, o termo ela refere-se a uma vizinha de uma das Falantes, que havia acabado de colocar seios de silicone, e que já era o tema da conversa, tanto que aparece anteriormente no fragmento ela queria sair. Trata-se, portanto, do Tópico da sentença, com função semântica de Ator e não aparece em $\mathrm{P}^{\prime}$. Neste caso, o constituinte ela, com função pragmática, ocupa uma posição relativa à $\mathrm{PF}$, porque a posição absoluta de $\mathrm{PF}^{\mathrm{F}}$ já está ocupada pelo modificador lá pro shopping. E, como vimos no capítulo 3 , constituintes hierárquicos têm prioridade de posicionamento nas posições mais extremas, indo em direção centrípeta à $\mathrm{PM}^{\mathrm{M}}$. O esquema de posições que propomos para (16), portanto, é o seguinte:

93 Na verdade, esse exemplo não integra o tipo de construção que constitui nosso objeto de pesquisa neste trabalho, já que se trata de um EsCo não-dinâmico e de uma estrutura com o verbo ser, de identificação. No entanto, nos pareceu interessante trazê-la para explicar nossa ideia de possibilidade de que Tópico ocupe $\mathrm{P}^{\mathrm{F}}$ em $\mathrm{PB}$. 


\begin{tabular}{|c|c|c|}
\hline $\mathbf{P M}^{\mathrm{M}}$ & $\mathbf{P}^{\mathrm{F}-1}$ & $\mathbf{P F}^{\mathrm{F}}$ \\
& TOP & \\
\hline foi & ela & lá pro shopping \\
\hline
\end{tabular}

Nossa conclusão até aqui, portanto, é que, em PB, constituintes com função de Tópico podem ocupar tanto domínio de $\mathrm{P}^{\mathrm{I}}$ como domínio de PF, embora a ordenação mais frequente seja em $\mathrm{P}^{\mathrm{I}}$, coincidindo com a função sintática de Sujeito.

Como já havíamos visto no capítulo 3 , em EP, Tópicos também podem coincidir com a função de Sujeito e ocupar $\mathrm{P}^{\prime}$, em sentenças como (17) e (18), que retomamos: ${ }^{94}$

\begin{tabular}{|c|c|c|}
\hline $\begin{array}{c}\mathbf{P}^{\mathbf{I}} \\
\text { TOP }\end{array}$ & $\mathbf{P}^{\mathbf{M}}$ & $\mathbf{P}^{\mathrm{M}+1}$ \\
\hline el Madrid & tiene & muy buenos jugadores \\
\hline
\end{tabular}

(18)

\begin{tabular}{|c|c|c|}
\hline $\mathbf{P I}^{\mathbf{I}}$ & $\mathbf{P M}^{\mathbf{M}}$ & $\mathbf{P}^{\mathbf{M}+1}$ \\
TOP & & \\
\hline ésta & ha hecho & primaria \\
\hline
\end{tabular}

Os exemplos (17) e (18), assim, evidenciam uma semelhança de ordenação em ambas as línguas. Outra semelhança é que em EP também há Tópicos múltiplos, como vimos em (2) no PB, e como mostramos em (19):

94 Como esses exemplos já foram apresentados nos capítulos anteriores, com seus contextos maiores, seus arquivos de áudio e suas referências, optamos por retomar, neste capítulo, somente o fragmento que nos interessa para a análise das funções pragmáticas e retóricas. Sempre que apresentarmos um novo exemplo, no entanto, voltaremos a indicar todos esses itens. 


\begin{tabular}{|c|c|c|c|c|c|}
\hline $\mathbf{P l}^{\mathbf{1}}$ & $\mathbf{P}^{\mathrm{l}+1}$ & $\mathbf{P M}^{\mathrm{M}-2}$ & $\mathbf{P}^{\mathrm{M}-1}$ & $\mathbf{P M}^{\mathrm{M}}$ & $\mathbf{P F}^{\mathrm{F}}$ \\
TOP & TOP & & & & \\
\hline yo & $e s o$ & $s e$ & $l o$ & he dicho & cien mil vezes \\
\hline
\end{tabular}

O exemplo (19) já nos indica outra semelhança entre as duas línguas: em EP, também é possível que Tópico não coincida com o Sujeito, já que eso tem função de Objeto.

Em EP, assim como vimos nos exemplos (14), (15) e (16) do PB, Sujeitos Tópicos também podem ocupar domínio de $\mathrm{PF}$, o que ocorre em (20), que retomamos a seguir. Outros casos de Sujeito Tópico apareceram no corpus, mas deixaremos para abordar essa questão um pouco mais adiante, na seção sobre as sentenças Téticas.

\begin{tabular}{|c|c|c|c|c|}
\hline $\mathbf{P M}^{\mathbf{M}}$ & $\mathbf{P}^{\mathrm{M}+1}$ & $\mathbf{P}^{\mathrm{F}-1}$ & $\begin{array}{c}\mathbf{P F}^{\mathbf{F}} \\
\text { TOP }\end{array}$ & $\mathbf{P}^{\text {pos }}$ \\
\hline tiene & trabajo & allí & el chaval & no \\
\hline
\end{tabular}

Até agora, a partir dos exemplos dados até aqui pareceria que não há grandes diferenças com relação à ordenação de Tópico nas duas línguas. No entanto, ao analisar e comparar os dois corpora, percebemos uma nítida diferença quanto à frequência de uso dessas estruturas nas duas línguas. Como já dissemos, o PB prefere manter TOP em $\mathrm{P}^{\mathrm{I}}$ e sobrepor as funções sintáticas e pragmáticas de Sujeito e Tópico. Por outro lado, constatamos que o EP recorre muito mais frequentemente a TOP em PF, sendo eles Sujeitos ou Objetos.

Como dissemos anteriormente, o Tópico também pode retomar informações referentes ao espaço e ao tempo, que fazem parte do Componente Contextual. É por isso que "[...] a função Tópico pode ser atribuída a Subatos que servem para indicar o cenário (setting) do estado-de-coisas evocado [...]" (PEZATTI, 2012, p. 366). Neste caso, Palavras dêiticas como agora e aqui, por exemplo, ou constituintes que tradicionalmente desempenham a função sintática de Adjunto Adverbial podem desempenhar a função pragmática de Tópico. É o que ocorre no seguinte exemplo: 

quem compra só eu / né / minha filha // (C-ORAL-BRASIL-bfamcv02).

No exemplo (21), os constituintes lá em casa e presente da minha família constituem dois Tópicos: o primeiro indica o cenário, o lugar de ocorrência do EsCo: supõe-se que o Interlocutor conheça como é lá em casa (como as coisas acontecem), conhecimento pressuposto reforçado, inclusive, pela expressão cê sabe. Esse TOP é constituído por um Modificador (lá), que, por ser dêitico/genérico, precisa de um termo que funcione como Aposto Especificador (em casa), a fim de esclarecer o termo anterior. Assim, esse primeiro TOP é formado por um modificador mais um Aposto Especificador, indicando um cenário. Já o segundo Tópico indica a entidade sobre a qual se constrói o comentário e que retoma o assunto em discussão: presentes. $\mathrm{O}$ exemplo (14) nos mostra que é perfeitamente possível haver Tópicos múltiplos em PB, ou seja, existir mais de um TOP no mesmo Conteúdo Comunicado. Em nosso trabalho, não nos interessa analisar este tipo de TOP, devido a ele não ser um constituinte Configuracional (e que, portanto, foge ao escopo do que nos propomos neste momento) e, por esta razão, não o exemplificaremos em EP.

Outro constituinte interessante que pode ocupar $\mathrm{Pl}^{\mathrm{I}}$ com a função de TOP em PB é um verbo no infinitivo, como no exemplo (22), e, neste caso, tem função semântica de Inativo:

\section{*EDE: ô Fifi // fofocar nũ vale não hhh // (C-ORAL-BRASIL-bfamcv15)}

Em (22), o termo ô Fifi, exercendo a função sintática de vocativo (segundo a classificação consagrada em nossas gramáticas mais usadas), configura um Ato Discursivo Interativo Nuclear, ou seja, não dependente de outros Atos Comunicativos. Por isso, ele deve ser analisado como uma unidade autônoma e não apenas como constituinte extraoracional, que, mesmo não compondo a Oração, não é um Ato Discursivo independente. A função desse termo é a de chamar a atenção do interlocutor, designando-o. Na língua, também existem Atos Interativos sem designação, tais como Oi! e Ei! Isso explicado, o esquema de posições de (22) pode ser assim representado: 


\begin{tabular}{|c|c|c|c|}
\hline P'/TOP & $\mathbf{P}^{\mathrm{M}-1}$ & $\mathbf{P}^{\mathbf{M}}$ & $\mathbf{P}^{\mathbf{M}+1}$ \\
\hline fofocar & não & vale & não \\
\hline
\end{tabular}

Não encontramos nenhum caso de verbo no infinitivo com função de Tópico em nosso corpus do EP.

A seção a seguir tratará de uma característica muito marcante no EP, que são os Tópicos duplicados.

\subsubsection{Os Tópicos Duplicados}

De acordo com Groppi (2008, p. 1), "As duplicações pronominais são estruturas oracionais com dois elementos que têm o mesmo referente e que estão relacionados com um mesmo complemento do verbo". ${ }^{95}$ Considerando os tipos de pronomes em espanhol (tônicos - tais como yo, tú, mí, ti, entre outros - e átonos - tais como me, te, nos, entre outros), Groppi (2008, p. 2) chama a atenção para sua funcionalidade: são as formas tônicas que servem para "[...] chamar a atenção do ouvinte, para iluminar um contraste, para ajudar a memória do interlocutor [...]". ${ }^{96}$

A pesquisadora ressalta as razões pragmáticas para o uso das duplicações, já que elas não são necessárias para a boa formação estrutural de uma sentença, do ponto de vista sintático. Portanto, optar por usar uma duplicação é uma escolha do Falante, a partir de suas intenções comunicativas, e por isso estão, segundo a autora, relacionadas às funções de tópico e/ou foco. ${ }^{97}$ Apesar de talvez as noções de Tópico e Foco que adotamos neste trabalho poderem divergir das adotadas pela pesquisadora, o que nos interessa aqui é assinalar que já se indicava a funcionalidade dessas estruturas.

Groppi (2008) afirma que não é possível duplicar elementos que não sejam específicos, ou seja, "[...] é necessário que para o falante exista um referente

\footnotetext{
95 Tradução nossa do original: Las duplicaciones pronominales son estructuras oracionales con dos elementos que tienen el mismo referente y que están relacionados con un mismo complemento del verbo.

96 Tradução nossa do original: [...] llamar la atención del oyente, para iluminar un contraste, para ayudar la memoria del interlocutor [...].

${ }^{97}$ Escritos aqui com iniciais minúsculas para manter a forma usada pela autora.
} 
identificável, do contrário o clítico não pode ser usado". ${ }^{98}$ Nós corroboramos essa constatação, pois em todas as ocorrências em nosso corpus, o clítico é correferente a um constituinte que aparece anteriormente, sempre determinado. Além disso, essa obrigatoriedade vem ao encontro do que explicamos no início deste capítulo, da relação unívoca entre Tópico e determinação/especificação.

Esses constituintes retomados são, nos dois exemplos a seguir, Tópicos (esa partitura e eso). E, como esclareceremos ainda melhor na seção seguinte, é justamente o uso do clítico que vai diferenciar estruturas de TOP ocupando $\mathrm{P}^{\mathrm{I}}$, como essas que acabamos de mostrar, de estruturas de Foco ocupando $\mathrm{P}^{\prime}$. Observe-se que, nesse caso, os constituintes focalizados não são retomados por clíticos, como ocorre em Un Óscar se lleva, em que un Óscar não é retomado por um clítico por ser o Foco da sentença. Centremo-nos, por ora, na ideia dos Tópicos duplicados.

Houve 23 ocorrências de duplicações em nosso corpus de EP, aos quais atribuímos interpretações diferentes. Nesta seção traremos somente alguns exemplos que acreditamos ter relação com a marcação de Tópico, embora algumas vezes possa-se sobrepor a função de Contraste, como veremos:

(23) *LOL: [<] <mira> / llevo tres días / que me [///] digo bueno me voy a acostar //\$ entonces paso por la habitación del teclado y digo /\$ jhum! / jay! esa partitura debería / mirármela un momento /(C-ORAL-ROM-efamdl01) $)^{99}$

[essa partitura deveria olhá-la um momento] [eu deveria olhar essa partitura um momento]

(24) $\quad{ }^{*} D E B: /[<]<a l$ final> acabas / entre los cinco primeros //\$ no voy a decir / que ganes a Schumacher / porque eso <lo veo / muy difícil $>/ / \$$

${ }^{*}$ FUE: $[<]<$ no //\$ el tiempo de Schumacher> / está muy difícil //\$ (C-ORAL-ROMepubdl09)

[porque isso $\varnothing$ vejo muito difícil]

[porque isso eu vejo/acho muito difícil]

Vemos que a determinação e a especificidade dos constituintes é uma questão primordial para entendermos as duplicações (ou não) no Espanhol e

98 Tradução nossa do original: [...] es necesario que para el hablante exista un referente identificable, de lo contrario el clítico no puede ser usado.

${ }^{99}$ Mantemos aqui essa ocorrência para exemplificar um caso de uso de dativo, mas não a analisaremos por se tratar de uma sentença composta, o que extrapola nossos objetivos de pesquisa neste momento. 
diferenciar, muitas vezes, Tópico de Foco. Vemos também que em (24) houve a omissão do Sujeito: Eso $\varnothing$ lo veo muy difícil. Por isso, é gerada uma ordem que poderíamos representar por $\mathrm{O}^{2} \mathrm{~V}$, em que $\mathrm{O}^{2}$ indica um Objeto duplicado (e não múltiplo, já que são correferenciais). Vemos que, na tradução funcional que sugerimos dessa sentença ao PB, a ordem é diferente (OSV) e o Sujeito é realizado (eu).

Assim, o Falante hispano prefere enunciar algo como (24) ao invés de (24'), que criamos a modo de comparação, e que segue a ordem canônica com o Objeto posposto ao verbo:

\section{? (Yo) veo eso muy difícil.}

[Eu) vejo/acho isso muito difícil

Vemos que, caso fosse escolhida a ordem canônica (como em 24'), que nos parece muito pouco provável de ser enunciada dessa maneira na língua espanhola, não seria necessário o uso do clítico lo. Aqui, a ordenação mais estranha do EP, (S)VO, pareceria ser a menos marcada em PB. A diferença entre as traduções de (24) e (24') nos indica que (S)VO, com Sujeito sendo o Tópico, é de fato a ordem mais usual em PB e com sentido apenas declarativo, o que nos leva à hipótese de que a ordem OSV, como vimos acima, teria uma motivação especial, que entendemos ser de Contraste: dentre todas as coisas que poderiam ser fáceis ou difíceis, essa, à qual se refere o Falante, é especialmente difícil. Esse valor de contraste não está presente nessa ordenação do EP, justamente por essa ser a ordem menos marcada nessa língua. Assim, o valor de Contraste, em EP, será obtido justamente pela ordem que é a mais natural em PB.

Vejamos mais claramente essa diferença entre as duas línguas com os esquemas de posição de (24) e suas traduções (não equivalentes entre si, já que na primeira há valor de Contraste). Acrescentamos nos esquemas as funções sintáticas dos termos para visualizarmos as ordenações dos tipos SVO, OSV e O²V:

\begin{tabular}{|c|c|c|c|}
\hline $\begin{array}{c}\mathbf{P}^{\mathbf{l}} \\
\text { TOP }^{2}\end{array}$ & $\begin{array}{c}\mathbf{P}^{\mathrm{I+1}} \\
\text { TOP }\end{array}$ & $\mathbf{P}^{\mathrm{M}}$ & \\
\hline eso & lo & veo & muy dificil \\
\hline OBJ. & OBJ. & & \\
\hline
\end{tabular}




\begin{tabular}{|c|c|c|c|}
\hline $\mathbf{P}^{\mathbf{I}}$ & $\mathbf{P}^{\mathrm{I}+1}$ & $\mathbf{P}^{\mathrm{M}}$ & $\mathbf{P}^{\mathrm{M}+1}$ \\
TOP & TOP & & \\
\hline isso & $\mathrm{eu}$ & acho & muito difícil \\
\hline OBJ. & SUJ. & & \\
\hline
\end{tabular}

No esquema de posicionamentos da sentença em EP, alocamos o clítico lo em posição absoluta de $\mathrm{P}^{\mathrm{I}}$ e o sintagma eso em $\mathrm{P}^{\mathrm{l}-1}$, marcando-o com a sigla TOP ${ }^{2}$ para indicar Tópico duplicado, com base nas propostas de Groppi (1993, 2004, 2016) e de Zorzo-Veloso $(2009,2016)$ de que "Por estruturas com pronomes clíticos e duplicação entendemos a presença de um pronome clítico e um sintagma correferente com o clítico na mesma oração" (GROPPI \& ZORZO-VELOSO, 2016, p. 259). ${ }^{100}$ As autoras defendem, assim como nós, que há uma motivação pragmática para o uso das duplicações em EP. Isso se vê claramente se se comparam sentenças gramaticais como (a) Lo vi e (b) Lo vi a él e a agramatical (c) *Vi a él: as autoras explicam que, a terceira sentença mostra que é impossível preencher argumentalmente o verbo por um sintagma com pronome forte (él) sem a presença do clítico. Isso indica que é o clítico que ocupa o lugar argumental. Como o sintagma não é o argumento, o clítico é, portanto, essencial para satisfazer a exigência argumental do Predicado. Por isso, "De um ponto de vista sintático, os clíticos são analisados como os elementos argumentais e os sintagmas correferentes, como elementos adjuntos." (GROPPI \& ZORZO-VELOSO, 2016, p. 260) ${ }^{101}$

Podemos, ainda, acrescentar a sentença (c) às já apresentadas: (c) Lo vi a Juan. Nesse caso, assim como em (b), o sintagma redundante (a Juan) pode servir a dois propósitos: (i) simplesmente aclarar o referente do clítico, funcionando como elemento anafórico; ou (ii) desambiguar o referente do clítico e contrastá-lo com algum outro referente possível: lo vi a Juan y no a María. Para essa segunda funcionalidade, no entanto, além da duplicação seria também necessário recorrer à marcação prosódica sobre o constituinte contrastado. Nesse caso, o constituinte a Juan amalgamaria as funções pragmáticas de Tópico e de Contraste.

100 Tradução nossa do original: Por estructuras con pronombres clíticos y duplicación entendemos la presencia de un pronombre clítico y un sintagma correferente con el clítico en la misma oración.

101 Tradução nossa do original: Desde el punto de vista sintáctico, los clíticos son analizados como los elementos argumentales y los sintagmas correferentes, como elementos adjuntos. 
Todo esse percurso nos permite voltar àquela divergência à qual nos referimos anteriormente entre as sentenças (13) - fluência oral a gente não avalia no homework e (19) - yo eso se lo he dicho cien mil veces. Comparando (13) e (19), que são sentenças com Tópicos múltiplos, vemos que, enquanto no PB se topicalizou um Objeto seguido de um Sujeito, o que gerou uma ordem OSV, em EP se topicalizou um Sujeito seguido de Objeto, o que gerou uma ordem SOV. Parece-nos muito menos frequente, embora possível, essa ordenação SOV em PB: acreditamos que o Falante prefira manter a ordem OSV e enunciar a sentença Isso eu lhe disse cem mil vezes, como equivalente à do EP que apresentamos, ao invés de manter a ordem preferida em EP: Eu isso Ihe disse cem mil vezes.

A comparação dessas 3 sentenças (13), (19) e (24) com suas respectivas traduções nos indica duas preferências diferentes em cada uma das línguas: o PB prefere manter os Sujeitos expressos e gera Tópicos múltiplos quando o Objeto ocupa $\mathrm{P}^{\mathrm{I}}$, ou seja, Objeto e Sujeito serão Tópicos, ambos em $\mathrm{P}^{\mathrm{l}}$. Em EP, a preferência é de não expressar os Sujeitos por meio lexical ou pronominal, como ocorre em (24) - Eso $\varnothing$ lo veo muy difícil. Por isso, é gerada a ordem $\mathrm{O}^{2} \mathrm{~V}$. Isso mostra uma clara tendência do EP de topicalizar Objetos e ao mesmo tempo não topicalizar Sujeitos. Desse modo, quando esses Sujeitos são topicalizados e expressos em EP, como ocorre em (19), a interpretação sugerida é de que alguma função especial há nessa ordenação. Essa função especial, segundo nosso ponto de vista, especificamente no exemplo dado, é o de marcar irritação (valor reforçado pela hipérbole do número cien mil veces), o que indica que o Falante já está cansado de repetir a mesma coisa. Esse yo expresso, portanto, parece indicar que o que ele podia fazer, ele já fez: há uma marca de isenção de culpa, e, pragmaticamente, pensamos que esse Tópico yo coincida com a função de Contraste (não sei se outras pessoas disseram, mas EU disse).

Em outros exemplos, em que o constituinte retomado teria a função sintática de Objeto Direto na GT, como em (25) e (26), ocorre algo semelhante.

\section{[...] a mi padre le han operado también [...]}

[o meu pai o operaram também]

[o meu pai eles operaram também]

Aqui, o Falante escolhe colocar o constituinte a mi padre na P' para marcar a função de Contraste, já que, anteriormente, o Falante diz que sua mãe foi operada: 
"[...] luego operaron a mi madre [...]" [depois operaram a minha mãe]. Note-se que, nesse primeiro Ato Discursivo, o Falante opta por manter a ordem canônica dos constituintes e, portanto, não há necessidade de duplicação. Sugerimos que essa escolha se deve ao fato de não haver aí intenção de marcar nenhuma função comunicativa especial, pois deseja-se apenas dar uma informação. Por outro lado, quando o Falante quer comparar e contrastar essa informação com a seguinte (a operação do pai), ele opta por colocar o constituinte que expressa a informação nova (a mi padre) antes do constituinte já conhecido, por ser comum à informação anterior (o verbo operar).

Algo interessante sobre a colocação do Objeto Indireto (entendido como o receptor da ação verbal e que na GDF corresponde à função semântica de Locativo) em $\mathrm{P}^{\mathrm{I}}$ é o que se observa em (26): a ausência da preposição a antes do constituinte antecipado:

[...] todos los niños que son feitos se les dice que son graciosos [...]

[todas as crianças que são feinhas se lhes diz que são graciosas] [pras crianças feinhas a gente sempre diz que são bonitinhas]

Note-se que o Falante prefere suprimir a preposição, ao invés de dizer a todos los niños que son feitos se les dice que son graciosos, o que manteria a marca morfológica, que, neste caso, indicaria o Objeto Indireto (ou, nos termos da GDF, o Locativo). Acreditamos que essa supressão se deva à possibilidade de o constituinte todos los niños que son feítos ser interpretado/sentido pelo Falante como sendo o Tópico da Oração. Essa nossa interpretação é reforçada pelo uso do verbo na terceira pessoa do singular concomitante ao uso de se (se les dice), que indeterminam o Sujeito Agente. Novamente, cremos que essa seja mais uma estratégia de não topicalização dos Sujeitos em EP, o que explica muito da alta frequência de Sujeitos pospostos nessa língua, que parece ser a grande motivação por trás de várias ordenações nessa língua, diferente do PB, que prefere manter os Sujeitos topicalizados.

Antes de continuarmos comparando as estruturas com Tópicos nas duas línguas, apresentaremos um dilema teórico com o qual nos deparamos para a análise dos Tópicos duplicados em EP, bem como nossa proposta de análise. Isso explicará 
nossas escolhas de posicionamento dos constituintes nos esquemas das sentenças (19) e (24), comparadas com três outras sentenças que criamos a seguir.

A primeira sentença imaginada é Vi a Juan en la plaza [vi (o) Juan na praça]. O contexto de enunciação corresponderia a uma conversa entre duas pessoas que conhecem o Juan e que se encontram. E, de repente, uma delas se lembra de dizer: ah, vi a Juan en la plaza, ou seja, tem mero valor declarativo, informativo. O esquema de posições dessa sentença seria o seguinte:

\begin{tabular}{|c|c|c|}
\hline $\mathbf{P}^{\mathrm{M}}$ & $\mathbf{P}^{\mathrm{M}+1}$ & $\mathbf{P}^{\mathbf{F}}$ \\
\hline$v i$ & a Juan & en la plaza \\
\hline
\end{tabular}

No esquema acima, como o termo Juan não tem função pragmática, ocupa domínio de PM. O Sujeito, que corresponde ao Tópico, e ocuparia PI, é omitido.

A segunda sentença é imaginada como a resposta a uma pergunta. A pergunta seria: ¿Dónde viste a Juan? [Onde (foi que) você viu (o) Juan?], cuja resposta seria Lo vi en la plaza [Eu vi ele/o vi na praça]. Claramente o clítico lo se refere a Juan e é a informação conhecida entre os Interlocutores, sobre quem se requer uma informação. Lo, portanto, é o Tópico da sentença da resposta. Não cabe dúvida de que esse clítico, Tópico, por ganhar uma função pragmática, ocupe $\mathrm{P}^{\mathrm{I}} \mathrm{da}$ sentença:

\begin{tabular}{|c|c|c|}
\hline $\mathbf{P}^{\mathbf{I}}$ & $\mathbf{P}^{\mathrm{M}}$ & $\mathbf{P}^{\mathbf{F}}$ \\
TOP & & FOC \\
\hline lo & vi & en la plaza \\
\hline
\end{tabular}

Até aqui, não temos nenhum dilema teórico e tudo o que falamos anteriormente se encaixa perfeitamente: constituintes com função pragmática ocupando posições absolutas externas, ou seja, $\mathrm{Pl}^{\mathrm{I}}$ ou $\mathrm{P}^{\mathrm{F}}$ (nos nossos exemplos ocupam $\mathrm{P}^{\prime}$ ); tendência de Tópicos ocuparem $\mathrm{P}^{\mathrm{I}}$; tendência do EP não topicalizar os Sujeitos e topicalizar os Objetos. O dilema começa, no entanto, quando aparecem os Tópicos duplicados. Que posição ocupam os clíticos e que posição ocupam os Sintagmas correferentes a eles?

Imaginemos nosso terceiro contexto: uma mãe preocupada por não saber onde exatamente estão seus dois filhos, Juan e Lola. O pai Ihe diz então: $A$ Juan lo vi 
en la plaza. O que se pressupõe é que o pai sabe somente onde o Juan está, mas não viu onde está Lola. Há, portanto, um caráter aclarador e contrastivo na escolha do Tópico duplicado, conforme explicamos anteriormente, com base em Groppi (1993, 2004, 2016) e de Zorzo-Veloso $(2009,2016)$. A proposta de posicionamento que fazemos para essa sentença é a seguinte:

\begin{tabular}{|c|c|c|c|}
\hline $\mathbf{P}^{\mathrm{I}}$ & $\mathbf{P}^{\mathrm{I}+1}$ & $\mathbf{P}^{\mathrm{M}}$ & $\mathbf{P F}^{\mathrm{F}}$ \\
\hline A Juan & lo & vi & en la plaza \\
TOP $^{2}$ & TOP & & \\
+ CONTRASTE & & & \\
\hline
\end{tabular}

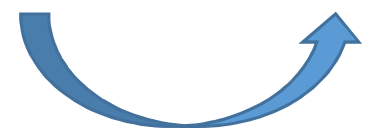

Conforme vimos no capítulo 3, segundo a GDF, as posições absolutas $\mathrm{Pl}^{\mathrm{I}}$ e $\mathrm{P}^{\mathrm{F}}$ têm preferência para abrigar constituintes com funções pragmáticas. Os Tópicos duplicados do EP nos mostram que essa língua, nessas construções, vai contra esse princípio de preferência proposto pela GDF. Para não contradizer esse princípio de preferência, havíamos pensado na possibilidade de manter a Juan em $\mathrm{P}^{\mathrm{I}}$ e colocar lo em $\mathrm{P}^{\mathrm{M}-1}$, o que caberia perfeitamente também com a proposta de Groppi (1993, 2004, 2016) de que o clítico é o verdadeiro argumento do Predicado. Assim, em domínio de $\mathrm{PM}^{\mathrm{M}}$, esse clítico estaria talvez melhor representado do ponto de vista de sua argumentalidade. No caso de ter assumido essa postura interpretativa, a Juan seria o único Tópico e o clítico seria correferente a ele. Isso equivaleria a repensar a nomenclatura Tópicos duplicados (ou duplicação de Tópicos), já tradicionalmente atribuída a esses casos. No entanto, foram sentenças como a (19) que nos levaram a repensar essa primeira postura interpretativa e a refutá-la. Vejamos novamente o esquema de (19):

\begin{tabular}{|c|c|c|c|c|c|}
\hline $\mathbf{P}^{\mathbf{I}}$ & $\mathbf{P}^{\mathrm{l}+1}$ & $\mathbf{P}^{\mathrm{M}-2}$ & $\mathbf{P}^{\mathrm{M}-1}$ & $\mathbf{P}^{\mathrm{M}}$ & $\mathbf{P}^{\mathrm{F}}$ \\
TOP & TOP2 & & TOP & & \\
+ \\
CONTR. & & & & & \\
\hline yo & eso & se & lo & he dicho & cien mil veces \\
\hline
\end{tabular}

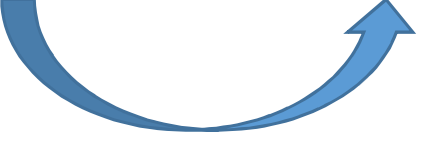


Ainda sem nem considerar o constituinte yo, imaginando que a sentença acima fosse constituída apenas por eso se lo he dicho cien mil veces, nosso dilema já se mostraria: como continuar alocando o clítico em domínio de $\mathrm{P}^{\mathrm{I}}$ nesse caso em que há um outro constituinte entre os dois que são correferentes (eso/lo)? Se fizéssemos isso, na tentativa de manter o Tópico, senão em posição absoluta de $\mathrm{P}^{\mathrm{I}}$ ao menos em posição relativa a ela, teríamos uma $\mathrm{P}^{\mathrm{l}}$ fragmentada, já que, entre os dois constituintes que a ocupariam, estaria o segundo argumento do verbo (se). ${ }^{102} \mathrm{O}$ esquema de posições seria o seguinte, bem estranho segundo nossa interpretação:

\begin{tabular}{|c|c|c|c|c|}
\hline $\begin{array}{c}\mathbf{P}^{\mathbf{l}} \\
\text { TOP}^{2} \\
\end{array}$ & $\mathbf{P}^{\mathrm{M}-1}$ ? & $\begin{array}{l}\mathbf{P}^{\mathbf{l + 1}} ? \\
\text { TOP }\end{array}$ & $\mathbf{P}^{M}$ & $\mathbf{P F}^{\mathrm{F}}$ \\
\hline eso & se & 10 & he dicho & cien mil veces \\
\hline
\end{tabular}

Como vemos na simulação acima, o constituinte se estaria em $\mathrm{P}^{\mathrm{M}-1}$ sem estar, no entanto, imediatamente à esquerda de $\mathrm{P}^{\mathrm{M}}$. E o constituinte 10 estaria em $\mathrm{P}^{\mathrm{I+1}}$ sem estar imediatamente à direita de $\mathrm{P}^{\mathrm{I}}$.

Nossa proposta para as sentenças com Tópicos clíticos e com os chamados Tópicos duplicados no EP é, então, a seguinte:

(1) quando há somente o clítico na sentença, sem o sintagma correferencial, o clítico ocupará posição absoluta de $\mathrm{P}^{\mathrm{I}}$ e será o Tópico;

(2) quando houver a combinação imediata (ou seja, sem outros constituintes entre eles) sintagma + clítico, correferentes (a Juan lo vi), o sintagma ocupará $\mathrm{P}^{\mathrm{I}}$ e o clítico, $\mathrm{P}^{\mathrm{l}+1}$, sendo ambos Tópicos e podendo acrescer-se a função Contraste ao constituinte que ocupa a $\mathrm{P}^{\prime}$;

102 Para o leitor que porventura não conheça o valor desse SE: trata-se do que, na perspectiva tradicional, tem-se denominado Objeto Indireto. É, em termos gerais, usado para substituir os termos a ele/a ela, indicando os receptores da ação (a quem se diz), já que em E não se diria yo ya he dicho eso para él. Esse para él, é representado pelo pronome clítico se, enquanto o clítico lo corresponde ao Objeto Direto (o que se diz), evitando-se, assim, uma cacofonia que seria produzida pelo grupo le lo. 
(3) quando houver a combinação imediata clítico + sintagma, correferentes (como seria na sentença Lo vi a Juan en la plaza), o clítico ocupará $\mathrm{P}^{\mathrm{I}}$ e o sintagma, $\mathrm{P}^{\mathrm{l}+1}$, sendo ambos Tópicos. Aqui, parece-nos que a função contrastiva não é tão forte quando em (2), entendemos que o sintagma a Juan está mais próximo de ter uma função simplesmente aclaradora, e isso justificaria que ele não ocupe posição absoluta de $\mathrm{P}$;

(4) quando houver combinação de clítico + sintagma não imediata (eso se lo he dicho), em que todos os constituintes ocupem posição à esquerda de $\mathrm{PM}^{\mathrm{M}}$ o clítico perde sua força pragmática e volta a ocupar domínio de $\mathrm{PM}^{\mathrm{M}} \mathrm{e}$ o sintagma é que será o Tópico, ocupando domínio de $\mathrm{P}^{\mathrm{I}}$ (ou posição absoluta de $\mathrm{P}^{\mathrm{I}}$, caso ela não esteja preenchida por outro constituinte).

A "regra" (4) que propomos acima nos fala sobre o clítico perder sua força pragmática. Explicamos: em casos como a sentença (19), acreditamos que a $\mathrm{P}^{\prime}$ é ocupada pelo constituinte que carrega, concomitantemente, duas funções pragmáticas: Tópico e Contraste. Isso Ihe dá, portanto, um caráter mais pragmático que o constituinte que carrega somente a função de Tópico. Isso nos parece condizente com a preferencialidade de que constituintes com função pragmática ocupem posições externas absolutas. O que estamos propondo, em outros termos, é que se considere uma escala gradual de pragmaticidade dos constituintes. Com isso, os constituintes mais pragmáticos ficariam mais externos e empurrariam os constituintes menos pragmáticos em direção à PM. É o que ocorre em (19) com o clítico: volta a ser mais argumental e sintaticamente importante, mas os valores pragmáticos mais fortes estão expressos pelos constituintes à sua esquerda.

Em (4) restringimos nossa proposição aos constituintes que ocupem posição à esquerda de $\mathrm{PM}$. Isso se deve a sentenças do tipo Lo vi a Juan en la plaza. Aqui, parece haver duas interpretações possíveis: a primeira delas seria considerar somente o clítico como Tópico e o termo a Juan como argumento que ocupa $\mathrm{P}^{\mathrm{M}+1}$. A escolha por essa decisão questionaria, novamente, o termo Tópicos Duplicados para esses casos. A segunda opção, que é a que nos parece mais coerente, seria a seguinte: 


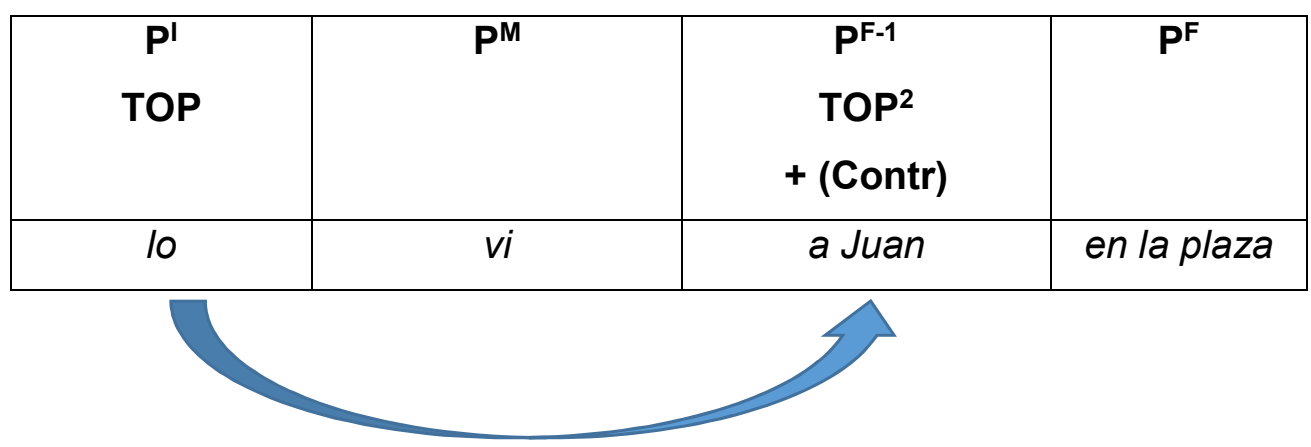

A proposta de posicionar a Juan em domínio de $\mathrm{P}^{\mathrm{F}}$ lhe garante o caráter pragmático de Tópico, já que, como já sabemos, tanto $\mathrm{P}^{\mathrm{I}}$ como $\mathrm{P}^{\mathrm{F}}$ são as posições que abrigam constituintes com função pragmática.

Paramos nossa divagação teórica por aqui, mas acreditamos que o que acabamos de apontar abre muitas possibilidades de análise e de pesquisa. Algumas perguntas que esse percurso nos sugere são: (i) o termo Tópicos Duplicados seria o mais adequado ao analisar sentenças como a (19), em que o clítico parece ir gradualmente perdendo sua função pragmática?; (ii) seria viável pensar em uma escala de gradualidade para os Tópicos, relacionada ao posicionamento desses constituintes na Oração?; (iii) é coerente propor que há constituintes mais carregados de pragmatismo, devido ao fato de carregarem concomitantemente funções de Tópico e Contraste ou de Foco e Contraste, como veremos na seção a seguir, e que por isso tenham preferência de posicionamento em $\mathrm{Pl}^{\mathrm{l}} \mathrm{e} \mathrm{PF}^{\mathrm{F}}$ ?

Além dessas perguntas, talvez essa incursão nos leve a pensar nas duplicações em EP de uma maneira ainda mais centrada em fatores pragmáticos, considerando os fatores semânticos (como definitude/determinação/genericidade/) como secundários. Por último, nos abre aqui um novo viés de comparação entre o PB e o EP: o PB tende a manter seus Tópicos muito mais frequentemente em $\mathrm{P}^{\mathrm{I}}$, enquanto a flexibilidade de ordenação do EP se revela também na flexibilidade de posicionamento de seus Tópicos: ora em $\mathrm{P}^{\mathrm{I}}$, ora em $\mathrm{PF}$, e ora, se considerarmos que os clíticos de sentenças como (19), são Tópicos duplicados, em domínio de PM. Terminamos assim, com muitas interrogações, isso que chamamos de dilema teórico. Não estamos certos de que nossas decisões quanto ao posicionamento desses Tópicos duplicados estejam corretas, mas foi necessário fazer uma escolha neste momento, ainda que frágil. 
As questões que apresentamos neste subcapítulo, relacionadas à expressão dos argumentos dos verbos em EP com formas pronominais, vazias ou duplicadas foram largamente estudadas e descritas por González (1994, 1998, 2000, 2005, 2008), que defende a tese de que o PB e o EP vêm passando por mudanças cruciais que se refletem em vários níveis da língua, e que revelam uma inversa assimetria ao que se refere à expressão desses argumentos nas duas línguas.

Retomaremos alguns exemplos apresentados nesta seção a fim de comentar e sintetizar alguns aspectos comparativos entre as duas línguas. Consideraremos apenas as traduções mais adaptadas, ou seja, aquelas que acreditamos manter a mesma funcionalidade discursiva da expressa na língua fonte e a mesma naturalidade, considerando contextos de falas coloquiais, embora saibamos que outras possibilidades de realizações seriam possíveis, em diferentes contextos, principalmente mais formais:

\begin{tabular}{|c|c|}
\hline Original & Tradução \\
\hline $\begin{array}{c}\text { 13. fluência oral a gente nũ avalia no } \\
\text { homework }\end{array}$ & $\begin{array}{c}\text { [la fluidez oral nosotros no la evaluamos en el } \\
\text { homework] }\end{array}$ \\
\hline $\begin{array}{c}\text { 20. tiene trabajo allí el chaval, ¿no? } \\
\text { 24. eso lo veo muy difícil }\end{array}$ & [esse moço tem trabalho lá, né?] \\
\hline $\begin{array}{c}\text { 25. a mi padre le han operado } \\
\text { también }\end{array}$ & [o meu pai eles operaram também] \\
\hline
\end{tabular}

De fato, se compararmos ocorrências acima com suas traduções, confirmamos o que defende González em vários de seus trabalhos sobre a expressão dos argumentos (tanto Sujeitos quanto complementos verbais) nessas duas línguas, ao dizer que é "[...] importante enfatizar que o espanhol admite anáfora zero de sujeito, mas não admite anáfora zero de objeto" (GONZÁLEZ, 1994, p. 126). Essas são nossas constatações, a partir das análises de nossos dados:

103 Por se tratar de uma conversa sobre aulas de inglês, preferimos manter o termo usado pela Falante nessa própria língua. 
(i) Em (13) o constituinte com função de Objeto em PB (fluência oral) ocupa $\mathrm{P}^{\prime}$ e é o Tópico do enunciado, que não é retomado/duplicado. Nossa tese é de que, quando topicalizados em $\mathrm{P}^{\mathrm{I}}$, os Objetos em $\mathrm{PB}$ tendem a ter valores contrastivos, como explicaremos na última seção deste capítulo. No nosso exemplo, é a fluência oral que não é avaliada no homework, o que pressupõe que outras habilidades linguísticas sim, são avaliadas no homework. $\mathrm{Na}$ tradução dessa sentença ao EP, vemos, no entanto, que o Tópico ganha um determinante que não existia no $\mathrm{PB},{ }^{104}$ e que, para se manter em $\mathrm{Pl}^{\mathrm{I}}$ deve obrigatoriamente ser retomado/duplicado por um clítico (la) e não expressa, necessariamente, um Contraste, já que essa é a estruturação mais frequente e menos marcada em EP. Em resumo, esse percurso nos leva a duas constatações: (1) Objetos Tópicos ocupando Pl em PB não é duplicado, e em EP, sim, por meio de um clítico; (2) o PB tende a gerar sentenças de Tópicos múltiplos com ordenação OSV, enquanto o EP com ordenação SVO.

(ii) O processo de (13) ocorre semelhantemente em (24) e (25), mas agora com o original em EP e a tradução ao PB: os constituintes com função sintática de Objeto no EP (eso e a mi padre) ocupam $\mathrm{P}^{\mathrm{I}}$ e são Tópicos dos enunciados. Por isso, são obrigatoriamente duplicados pelos clíticos $(l o, l e)$. Na tradução de (24) ao PB desaparece a duplicação, embora se mantenha o Objeto topicalizado em P'. Nota-se, porém, uma diferença importante entre a realização de (24) nas duas línguas que é a não realização do constituinte com função de Sujeito (que seria yoleu) em EP: não se diz eso yo lo veo muy difícil, enquanto no PB, ele é realizado. No PB, portanto, temos um caso de Tópico múltiplo (isso e eu), ambos ocupando $\mathrm{P}^{\mathrm{I}}$, o que indica que nas poucas vezes que se topicalizam Objetos em PB, se topicalizam, também, os Sujeitos. ${ }^{105}$ Enquanto isso, no EP temos um único Objeto/Tópico, duplicado, e a não realização do Sujeito/Tópico.

(iii) O mesmo que descrevemos em (ii) ocorre com os Objetos Indiretos, em (25): no EP são duplicados ao mesmo tempo que se apaga o Sujeito, por meio do uso de um verbo na terceira pessoa do plural, enquanto no PB não se

104 Por diversas razões, como comentamos brevemente quando falamos sobre os nomes nus.

105 Aqui não estamos considerando as construções clivadas, como ocorre em (21), por exemplo, em que se topicalizam os Objetos para focalizar e contrastar os Sujeitos. Nós retomaremos essa questão mais adiante. 
duplica o Objeto e se marca lexicamente o Sujeito (eles). Esses dados apontam, novamente, para a tese que defendemos de não topicalização dos Sujeitos em EP, em detrimento da topicalização dos Objetos. E em sua perfeita assimetria com o PB: um processo de topicalização dos Sujeitos e não topicalização dos Objetos.

(iv) A comparação de (20) confirma a tese que acabamos de anunciar acima, já que em EP o Sujeito está ocupando $\mathrm{P}^{\mathrm{F}}$, enquanto no $\mathrm{PB}$, está ocupando $\mathrm{P}^{\mathrm{I}}$. Como se trata de uma llocução Interrogativa, o que o Falante pretende é confirmar uma informação que ele pressupõe como correta (o moço tem trabalho lá). Como veremos na próxima seção sobre o Foco e mais detalhadamente no capítulo 6 , entendemos que todo esse enunciado compõe uma estrutura que chamamos de sentença semi-Tética, já que carrega um constituinte identificável pelos Participantes (o moço) e que por isso seria o candidato perfeito a Tópico, mas sobre quem não se comenta nada: o que se faz é requerer um comentário sobre ele, sendo, portanto, uma espécie de semi-Tópico. Por isso, em EP obrigatoriamente nas llocuções Interrogativas os Sujeitos devam ser pospostos aos predicados (colocados à sua direita), já que não se tratam de Tópicos em seu sentido pleno. Veremos, na seção seguinte, que esses semi-Tópicos não são exclusivos das sentenças Interrogativas. Em PB, no entanto, esse Sujeito, mesmo sendo semi-Tópico, continua ocupando $\mathrm{P}^{\mathrm{I}}$, pela tendência, como falamos, de manter Sujeitos em posições pré-verbais, dadas as maiores restrições semânticas impostas nessa língua.

Outro fenômeno a ser descrito aqui é o uso de pronomes demonstrativos pospostos aos Sintagmas nominais os quais determinam, como ocorre em (27), em que o nome piano é precedido pelo artigo definido el [o] e ao qual se pospõe o demonstrativo ése [esse]:

[...] el piano ése me lo /// va a venir muy bien para cuando vaya yo ${ }^{106}$

[o piano esse me $\varnothing$ vai vir muito bem para quando vá eu] [esse piano vai ser ótimo para mim quando eu for]

${ }^{106}$ Este exemplo também traz um dativo de afetação $(m e)$, do qual falaremos no item 4.2.4.1 da próxima seção. 
Segundo Leonetti (1999, p. 75), a condição imprescindível para que o demonstrativo apareça posposto ao nome é que esse esteja determinado por um artigo definido. Ocorre, então, segundo o autor, uma dissociação da definitude em duas posições conectadas, ou seja, a pré e a pós-nominal, sendo que o artigo, colocado numa posição inicial, indica o elemento de conteúdo mais geral e com traço [+definido], enquanto o demonstrativo, colocado em uma posição pós-nominal, indica o conteúdo mais específico e de localização dêitica. Assim, o uso do demonstrativo nessa posição revela um efeito interpretativo de orientação dêitica:

Portanto, enquanto que este libro apresenta o referente como algo conhecido, imediato e próximo, el libro este o situa em um espaço cognitivo mais remoto, como se o falante acrescentasse ao SN definido um marcador de familiaridade que não pode se antepor [...]. No entanto, os SNs com demonstrativos pospostos podem ser empregados para aludir a referentes já armazenados na memória do receptor, mas não presentes na situação nem no contexto discursivo (LEONETTI, 1999, p. 77). ${ }^{107}$

Sendo assim, essa construção Artigo + Nome + Demonstrativo, no EP, ao menos nos dados que obtivemos em nosso corpus, funciona justamente para resgatar uma informação, esteja ela apenas na memória do receptor ou também no contexto discursivo. Se resgatarmos o contexto maior do nosso exemplo (27a), vemos que o nome piano já havia sido mencionado anteriormente e que, portanto, o uso do demonstrativo posposto funciona como uma espécie de anáfora que chamaremos de mediato, pois resgata uma informação compartilhada pelos falantes e que apareceu anteriormente no discurso. Já o clítico lo funciona como elemento anafórico que chamaremos de imediato, pois retoma o constituinte que ocupa a $\mathrm{Pl}^{\mathrm{I}}$ e que funciona como Tópico:

(27b) *PIL: $[<]<$ hhh en bici> //\$ oye que $+\$$ porque Leonardo y \&c [//I] y eso [/] y llevaron el piano / pero el piano nada / para limpiarle el polvo //\$

*LOL: no //\$ el piano ése me lo [///] <va a venir muy bien / para cuando vaya yo> $+\$$ (C-ORAL-ROM-efamdl01)

107 Tradução nossa do original: Así, mientras que este libro presenta el referente como algo conocido, inmediato y cercano, el libro éste lo sitúa en un espacio cognitivo más remoto, como si el hablante añadiera al SN definido un marcador de familiaridad que no puede anteponerle [...]. Sin embargo, los SSNN con demostrativos postpuestos se pueden emplear para aludir a referentes ya almacenados en la memoria del receptor, pero no presentes en la situación ni en el contexto discursivo. 
Nesses casos, essa combinação de Palavras forma o constituinte que ocupa a $\mathrm{P}^{\mathrm{I}}$ (el piano ése) por ter a função de Tópico, sendo um recurso anafórico e coesivo do discurso.

A seguir, trataremos da segunda função pragmática prevista pela GDF: o Foco.

\subsection{Eu tenho é só vergonha $x$ Lo único que tengo es vergüenza: a função Foco}

\subsubsection{Noções gerais}

A segunda função pragmática considerada pela GDF é o Foco (representado pela sigla FOC). Hengeveld \& Mackenzie (2008), baseando-se em Dik (1989), propõem que a finalidade do Foco é indicar a escolha estratégica que o Falante faz em relação à informação nova de seu enunciado, para, por exemplo, preencher uma lacuna na informação do Destinatário, ou corrigir uma informação do Destinatário. O Foco é, portanto, uma instrução de atualização do Destinatário. ${ }^{108}$

Vemos que, para atribuir a função de Foco a um constituinte, não basta que esse constituinte carregue a informação nova do enunciado (como defendem outras teorias), pois essa é a finalidade do Comentário em relação ao Tópico. O Comentário é que informa, que acrescenta algum dado sobre o Tópico. Mais que isso, o Foco dá relevo/destaque a essa informação nova, indicando que essa é a parte mais importante de seu enunciado para o Interlocutor, como constatamos na seguinte afirmação de Pezatti (2012, p. 89):

A função Foco de uma expressão linguística é a informação relativamente mais importante ou saliente num dado contexto de interação verbal, e avaliada pelo Falante como essencial para ser integrada na informação pragmática do destinatário.

108 Tradução e adaptação nossa do fragmento original completo: The Focus function signals the Speaker's strategic selection of new information, e.g. in order to fill a gap in the Addressee's information, or to correct the Addressee's information. The Focus function is assigned only in those cases in which this is linguistically relevant, i.e. when languages use linguistic means to indicate that some part of a Linguistic Expression constitutes the relevant new information. The information not assigned the Focus function constitutes the Background. The linguistic marking of Background rather than new information seems to be very rare. In Smit (fc.) Focus is defined as an update instruction to the Addressee. 
Vale destacar que aqui estamos no campo da pragmática, nas relações discursivas e nas estratégias que o Falante usa para moldar seu conteúdo de fala a partir do conhecimento (ou da pressuposição que tem do conhecimento) de seu Interlocutor. Além disso, o Foco se aplica a Subatos discursivos e não a todas as camadas no Nível Interpessoal. São essas características que ajudam a diferenciar a função pragmática Foco da categoria pragmática Ênfase, da qual falaremos no item 4.3. Assim, um Comentário pode ser apenas um Comentário, como pode, também, ser o Foco do que se enuncia.

A contraparte do Foco, isto é, a porção de informação que não é nova e saliente, é o Fundo (background). Vale a observação aqui de que a contraparte do Foco não é o Tópico. A GDF não assume, portanto, a postura de outras linhas teóricas de que a estrutura de algumas línguas, como o português, por exemplo, é constituída de Tópico e Foco, em que tudo que não é um é outro.

No entanto, muitas vezes os enunciados, sim, coincidem com a estrutura TOP - FOC. Um bom exemplo dessa coincidência são os enunciados nos quais a marcação de Foco é realizada por meio de uma alteração prosódica, quando o Falante se vale de uma mudança na tessitura para destacar algum constituinte (e, portanto, atribuir-Ihe a função de Foco). ${ }^{109}$ Essa estratégia prosódica para marcação do Foco foge ao escopo deste trabalho, que se atem às estratégias de ordenação dos constituintes para a atribuição das funções pragmáticas. Desse modo, embora muito importante, não nos aprofundaremos nessa questão e apenas a apresentaremos como uma das estratégias que podem ser usadas em PB e em EP, mesmo que não nos detenhamos sobre ela.

Essa é a estratégia usada, por exemplo, nas respostas das perguntas do tipo $\mathrm{Q}^{110}$ em português e espanhol (Wh em inglês), como quem/quién, quando/cuándo, onde/dónde, etc. Sendo o Foco a informação nova relevante, é a informação veiculada por ele que responde e preenche essas lacunas na informação de Interlocutor. Vejamos o seguinte exemplo:

*LAU: Quem que falou?

*LUZ: gente / eu / te falei / a Fabíola / eu falei se ocê nũ faria // (C-ORAL-BRASIL - bfamdl03).

\footnotetext{
${ }^{109}$ Para maiores informações, ver Hengeveld \& Mackenzie, 2008, ps. 1296, quando se referem a [...] the focal status of constituents is manifested in prosodic diferences [...].

${ }^{110}$ Falaremos mais sobre as sentenças interrogativas no capítulo 6.
} 
Ao escutarmos o áudio do exemplo (28), percebemos que há uma diferença na tessitura dos constituintes eu e a Fabíola, que são os Focos da sentença e preenchem a informação requisitada pelo Interlocutor por meio do interrogativo quem. Assim, há duas respostas para a pergunta feita em (28), ou seja, há dois constituintes focais: eu te falei, a Fabíola [te falou], já que, como observamos pela entonação, esses constituintes preenchem a lacuna de informação do Interlocutor, ou seja, equivale a nós falamos (eu - Luzia - e a Fabíola).

Esse exemplo, portanto, nos mostra alguns aspectos importantes sobre o Foco em PB (e também em EP, apesar de não trazermos nenhum exemplo nessa língua, já que o Foco prosódico não é um tema central em nosso trabalho): (i) o Foco pode ser marcado prosodicamente; (ii) mais de um constituinte pode ser focal; (iii) quando se usa a estratégia prosódica, o Foco pode recair sobre qualquer constituinte e ocupar qualquer posição do esquema de posições proposto pela GDF, podendo, inclusive, ser concomitante a outras funções pragmáticas (como corre no nosso exemplo, em que Foco recai sobre um constituinte que também é o Tópico). Assim, a representação das posições de (28) seria:

\begin{tabular}{|c|c|}
\hline $\mathbf{P}^{\mathbf{l}}$ & $\mathbf{P}^{\mathrm{M}}$ \\
\hline Quem que & falou? \\
\hline
\end{tabular}

\begin{tabular}{|c|c|c|c|}
\hline Pre $^{\text {pre }}$ & $\mathbf{P}^{\mathbf{l}}$ & $\mathbf{P}^{\mathrm{M}-1}$ & $\mathbf{P}^{\mathbf{M}}$ \\
\hline gente, & eu & te & falei \\
& FOC + TOP & & \\
\hline
\end{tabular}

No exemplo (29), além da entonação, o Falante marca o Foco por meio do posicionamento do constituinte que carrega a informação nova relevante para o Interlocutor, alocando-o em PF:

*GIL: <é> // tem que olhar o trem com o Gilson //

${ }^{*}$ CAR: quem que é <esse Gilson>?

*VER: <isso> // Gilson <eletricista> // (C-ORAL-BRASIL-bfamcv12).

${ }^{111}$ A construção -que é um operador de Ênfase, que intensifica, no nosso exemplo, o operador de llocução quem, pois se posiciona sempre antes do elemento escopado. Os operadores de Ênfase, que escopam Subatos, referem-se à ordenação dos constituintes no âmbito do Sintagma e por isso fogem ao escopo do presente trabalho. No entanto, retomaremos essa questão um pouco mais adiante. 
Como vemos, existem diferentes recursos para a marcação dessa função pragmática. Há línguas que marcam o Foco somente pela entonação e outras que usam recursos especiais, como as Wh questions (ou perguntas $Q$ ). Conclui-se disso que "[...] a atribuição de um Foco a cada Conteúdo Comunicado é meramente uma preferência tipológica, não uma restrição universal" (HENGEVELD \& MACKENZIE, 2008, ps. 1308). ${ }^{112}$ A GDF concorda com Dik (1997a, p. 313), ao dizer que a atribuição do Foco pode ocorrer de diferentes maneiras nas línguas: (i) pela adaptação da forma; (ii) pela presença de um marcador (por exemplo, uma partícula); (iii) pela posição incomum na sequência de constituintes; (iv) por uma construção especial do Foco; (v) por um contorno prosódico especial (por exemplo, acentuação tônica) ${ }^{113}$.

Com base no conjunto de dados analisados nesta pesquisa, constatamos, que, nesse corpus, o PB dispõe dos seguintes recursos para a marcação de Foco: (i) prosódia; (ii) sentenças clivadas; (iii) construções passivas; (iv) posição incomum na sequência dos constituintes depois do Predicado e (v) uma construção especial, denominada Foco-ser. Já o espanhol, dispõe de (i) prosódia; (ii) sentenças clivadas (ou estruturas Equacionais); (iii) construções passivas e (iv) posição incomum na sequência dos constituintes depois do Predicado. Interessa-nos especialmente descrever os recursos (iv) e (v) do PB e o recurso (iv) do EP. No entanto, será inevitável não abordar os demais recursos, ainda que de maneira mais superficial. Isso porque muitas vezes um recurso que nos interessa descrever da língua $A$ só pode corresponder a um recurso que não é nosso foco de análise na língua $B$.

\subsubsection{A estratégia do Foco-ser na marcação de Foco em PB}

O PB pode se valer também de um operador de Ênfase para marcar o Foco, denominado Foco-ser ${ }^{114}$ (BRAGA, 2009; 2013). Trata-se do uso do verbo ser, flexionado no mesmo modo e tempo do verbo principal, e colocado antes do elemento escopado focalizado. Vejamos os exemplos:

\footnotetext{
112 Tradução nossa do original: Thus we may conclude that the assignment of one Focus to each Communicated Content is merely a typological preference, not a universal restriction.

113 Para maiores informações, ver Hengeveld \& Mackenzie, 2008, ps. 1308.

${ }^{114}$ Braga (2009; 2013) grafa a expressão Foco Ser sem hífen, enquanto Pezatti (2012) prefere grafá-la com hífen. Em nosso texto, adotaremos a forma de Pezatti.
} 
(30) *MAR: e cê [/1] cê [/1] cê usou lá foi esse cartão do [/1] do Banco do Brasil aqui / Ourocard internacional //\$ (C-ORAL-BRASIL-bfamdl21).

(31) *JON: <é o seguinte / eu acidentei> que eu lembro foi dia dois // quando eu vim voltar a mim mesmo / já era dia doze // (C-ORAL-BRASIL-bfamcv13)

(32) *RUT: <eu tenho é> só vergonha / de entrar <na igreja> // (C-ORAL-BRASILbfamcr02).

Pezatti (2014) defende que a estratégia de Foco-ser serve para focalizar exclusivamente constituintes que, canonicamente, já ocupariam $\mathrm{PF}$, mas que normalmente não constituiriam Foco (por exemplo, os Comentários, os constituintes com função semântica e os modificadores que indicam Causa, Locação e Modo): "Na verdade, construção de Foco-ser constitui uma estratégia para destacar elementos que, na ordenação canônica, já se posicionam no final da oração [...]" (PEZATTI, 2012, p. 92). A pesquisadora nos traz o seguinte exemplo:

\begin{tabular}{|c|c|}
\hline PM & PF \\
\hline (o canto da morna) saiu & foi destas raízes \\
\hline
\end{tabular}

(PEZATTI, 2014, p. 109)

Sobre (33), a autora explica que o constituinte destas raízes já constituía a informação nova requerida pelo entrevistador sobre a origem da palavra morna. Como esse constituinte aparece em sua posição canônica de Comentário (em PF), o Falante recorre ao uso do verbo ser, flexionado no mesmo tempo e modo do verbo principal (saiu) para sinalizar que essa é a informação mais importante de seu enunciado e que merece destaque, focalizando-a, portanto.

Essa mesma estratégia também pode ser verificada no nosso exemplo (31), em que o modificador dia dois, que indica Tempo, aparece em sua posição canônica $\left(\mathrm{P}^{\mathrm{F}}\right)$ e no nosso exemplo (30), cujas posições representamos abaixo:

\begin{tabular}{|c|c|c|c|c|}
\hline $\mathbf{P}^{\mathbf{I}}$ & $\mathbf{P}^{\mathbf{M}}$ & $\mathbf{P}^{\mathbf{M + 1}}$ & $\mathbf{P}^{\mathbf{F}}$ & $\mathbf{P}^{\mathbf{p o s}}$ \\
\hline cê & usou & lá & $\begin{array}{c}\text { foi esse cartão do Banco do } \\
\text { Brasil aqui }\end{array}$ & $\begin{array}{c}\text { Ourocard Internacional } \\
\text { (Esclarec.) }\end{array}$ \\
\hline
\end{tabular}


O Foco do exemplo (32), que é o complemento do verbo ter, é constituído por uma outra Oração e, como este tipo de estrutura foge ao escopo de nossas análises, preferimos alocar todo o constituinte em PF, embora saibamos que em uma análise mais pormenorizada o constituinte na igreja seria argumento de entrar e que de entrar, por sua vez, seria argumento de vergonha:

\begin{tabular}{|c|c|c|}
\hline $\mathbf{P}^{\mathbf{I}}$ & $\mathbf{P}^{\mathrm{M}}$ & $\mathbf{P}^{\mathbf{F}}$ \\
\hline eu & tenho & é só vergonha de entrar na igreja \\
\hline
\end{tabular}

Os dados nos indicam, portanto, que, em PB, realmente há uma tendência a que Focos ocupem $\mathrm{PF}^{\mathrm{F}}$, mas essa não pode ser tomada como uma regra para o $\mathrm{PB}$, que, além de casos como o acima, pode ter o Foco em $\mathrm{P}^{\mathrm{I}}$, como vimos no exemplo (26). Os dados também nos indicaram que as construções de Foco-ser, como observado por Braga (2009), são adequadas para a focalização de qualquer material que se coloque à direita do predicado verbal principal, nunca ocorrendo à sua esquerda.

Ainda sobre as construções de Foco-ser, Pezatti (2012, p. 97) nos diz que a "[...] construção Foco-ser determina as partes de uma unidade linguística que são apresentadas como particularmente importantes para o Destinatário acrescentar à sua informação pragmática ou corrigi-la. [...]." Ao dizer que as construções de Foco-ser podem corrigir informações do Destinatário, assume-se a possibilidade de existência do traço [+contrastivo] desse tipo de recurso. Isso significa que o Foco-ser pode indicar que um constituinte carrega, simultaneamente, as funções de Foco e de Contraste. Vejamos o exemplo (34):

$$
\begin{aligned}
& \text { *TER: < uhn> // aí / a Dani [/2] a Dani vai arrumar o dia todo na <casa da>+ } \\
& \text { *RUT: <tá quase na hora do Tetê chegar> // } \\
& \text { *TER: <ela vai> é pa casa das <noiva> (C-ORAL-BRASIL-bfamcv02). }
\end{aligned}
$$

No exemplo acima, ao ser interrogada pela interlocutora sobre onde vai a Dani, que é a noiva, tema da conversa, para se arrumar no dia do casamento, a Falante, ao invés de dizer, simplesmente, ela vai para a casa das noivas, preferiu usar uma construção de Foco-ser. Essa escolha pode ser explicada como uma tentativa de corrigir uma informação de sua Interlocutora, que pensa que a Dani vai se arrumar na casa de alguém (percebemos isso pelo trecho a Dani vai arrumar o dia todo na 
<casa da>+), em que o símbolo (+) na transcrição marca o final de um enunciado que é interrompido pelo interlocutor ou por eventos do ambiente. No nosso exemplo, a Falante é interrompida por sua Interlocutora, que, ao perceber que a amiga pressupunha uma informação errada, contrasta casa de alguém com casa das noivas, expressando, através do uso da estrutura Foco-ser, que a segunda informação é a única correta. Esse recurso, portanto, marca simultaneamente Foco e Contraste. O esquema de (34) pode ser assim representado:

\begin{tabular}{|c|c|c|}
\hline $\mathbf{P}^{\mathbf{I}}$ & $\mathbf{P}^{\mathbf{M}}$ & $\mathbf{P}^{\mathbf{F}}$ \\
& & FOC + CONT \\
\hline ela & vai & é pa casa das noiva \\
\hline
\end{tabular}

No exemplo acima, o constituinte é, por ser um marcador de função, fica dentro do sintagma que escopa, ou seja, dentro de $\mathrm{P} F$. Só dentro do sintagma é que ele vai ter uma posição, nesse caso a posição $\mathrm{P}^{\prime}$ do sintagma (e, como já dissemos, o estudo da ordenação sintagmática foge ao objetivo de nosso trabalho neste momento).

O verbo ser do Foco-ser pode estar, inclusive, combinado com outro verbo ser copulativo, em uma Oração atributiva como Ela é é linda. Imaginemos dois amigos conversando sobre uma garota e um deles diz: Ela é bonita. O segundo, então, corrigiria a informação sobre o grau de beleza da garota, usando nosso enunciado com o Foco-ser. Teríamos, novamente, um caso de Contraste.

Gostaríamos de destacar que o Foco-ser, segundo os exemplos dados por Braga (2009, 2013), por Pezatti (2012) e pelas ocorrências em nosso corpus, é um mecanismo geralmente usado para marcação de Foco de constituintes com função sintática de Objeto, ou, em outros termos, os constituintes Configuracionais que não coincidam com a função sintática de Sujeito. ${ }^{115}$ Para focalizar Sujeitos em PB, portanto, prefere-se recorrer a outras estratégias: as sentenças clivadas. ${ }^{116}$ Assim, como resposta à pergunta Quem toca o piano?, a resposta mais provável seria

\footnotetext{
115 Embora talvez não tão usuais, também são possíveis enunciados como Ficou foi o Pedro, em que a estratégia de Foco-ser está sendo usada para focalizar um constituinte com função sintática de Sujeito (Pedro).

116 Aqui, usamos o termo genérico clivadas para nos referirmos a todos os tipos de clivadas: pseudoclivadas, clivadas invertidas, etc. Justamente porque nosso intuito é apenas assinalar que esse é um dos recursos possíveis para marcação de Contraste em PB.
} 
simplesmente um sintagma que contivesse o Foco (como o João). ${ }^{117}$ Fora isso, as únicas possibilidades seriam (i) Quem toca o piano é o João / (ii) É o João que/quem toca o piano / (iii) O piano quem toca é o João. Porém, as duas últimas possibilidades, além de serem focais, são também contrastivas: em (ii) o que se contrasta é o termo João (é ele e não outra pessoa que toca); em (iii) o que se contrasta é o instrumento tocado (O João toca especificamente o piano, mas há outro(s) instrumento(s) que são tocados por outro agente).

Como nós não queremos falar sobre Contraste neste momento e como também o estudo das sentenças clivadas não fazem parte dos objetivos desta pesquisa, nos limitaremos a apontar que são essas as possibilidades para marcação de Sujeitos focais em PB (embora as sentenças clivadas funcionem para focalizar e contrastar qualquer outro tipo de constituinte, ou seja, não é uma estratégia exclusiva para os Sujeitos). Por outro lado, podemos dizer que a focalização dos Sujeitos só pode ser feita por meio das clivadas. Resumindo: em PB, as clivadas focalizam e contrastam qualquer constituinte. Mas Sujeitos só podem ser focalizados e contrastados por meio das clivadas (sempre desconsiderando as marcações prosódicas).

Os exemplos acima nos mostraram o que já havíamos explicado no capítulo e, que posições periféricas têm preferência de preenchimento sobre $\mathrm{P}^{\mathrm{M}}$, ou, em outras palavras, $\mathrm{P}^{\mathrm{I}}$ e $\mathrm{P}^{\mathrm{F}}$ são preenchidas antes que $\mathrm{P}^{\mathrm{M}}$, e em sua direção, ou seja, de $\mathrm{P}^{\mathrm{I}}$ para a direita e de $\mathrm{P}^{\mathrm{F}}$ para a esquerda, ambas em direção à $\mathrm{P}^{\mathrm{M}}$, como mostramos no esquema abaixo, de orientação centrípeta dos constituintes:

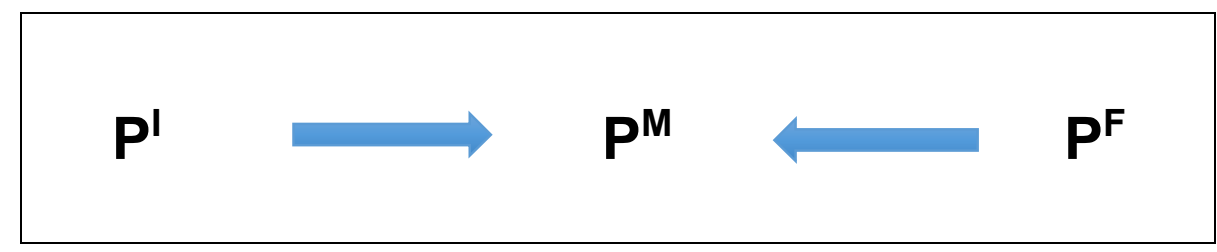

Esquema 20 - Orientação centrípeta dos constituintes

Em EP, não houve nenhuma ocorrência de sentenças com Foco-ser. Para verificar se nossa suspeita de que essa estratégia não existiria na língua espanhola,

\footnotetext{
117 Nós confirmamos e apresentamos esses dados no capítulo 5, quando abordamos as llocuções Interrogativas.
} 
ou seja, para ter certeza de que não fosse simplesmente uma coincidência a não ocorrência em nosso corpus e que a ausência dessas estruturas não se devesse ao gênero textual à variedade dialetal nele presentes, propusemos traduções literais para os exemplos das ocorrências em PB e consultamos sete hispanoparlantes nativos, sendo um deles argentino, uma chilena, uma mexicana, uma peruana e três espanholas (de Madri, que é a mesma variante do nosso corpus). Perguntamos se, segundo eles, essas sentenças poderiam ocorrer em sua variedade linguística, ou se as achavam estranhas. Todos os consultados disseram que todas são estranhas e que não as diriam em nenhum contexto. As traduções que nós propusemos e que não foram aceitas pelos nativos são as seguintes:

- $\quad$ Ela vai é pra casa das noivas. $\rightarrow$ Ella va es para la casa de las novias.

- $\quad$ Eu tenho é só vergonha. $\rightarrow$ Yo tengo es solo vergüenza.

- Você usou lá foi esse cartão de crédito do Banco do Brasil aqui? $\rightarrow$ ¿(Tú) usaste allá fue esta tarjeta del Banco do Brasil aquí?

- $\quad$ Eu acidentei foi dia dois. $\rightarrow(Y o)(m e)$ accidenté fue el día dos.

Embora não possamos afirmar categoricamente sem antes fazer um estudo ampliado a outras variedades da língua espanhola, os dados que obtivemos aqui (ou, melhor dito, a falta de dados) é um forte indício de que talvez o Foco-ser não seja uma estratégia para marcação de Foco em EP e que teríamos aqui mais uma assimetria em relação ao $\mathrm{PB}$. Como equivalentes funcionais a essas estruturas com Foco-ser do PB, o EP costuma recorrer ao que Gutiérrez Ordóñez (1997, p. 37), em sua reconhecida obra Temas, remas, focos, tópicos y comentários, denomina estruturas equacionais [estructuras ecuacionales]. ${ }^{118}$ Segundo o autor, essa é uma das possibilidades para destacar um constituinte, atribuindo-lhe ênfase. Essas estruturas estão compostas por três partes: (i) pelo constituinte que se pretende destacar; (ii) pelo restante da sequência introduzida por um relativo correferente ao constituinte enfatizado e (iii) pelo verbo ser. Como exemplos, o autor traz as seguintes possibilidades de focalização de constituintes a partir da sentença básica (sem focalização) El decano ha convocado junta para el lunes:

${ }^{118}$ Na verdade, Gutiérrez Ordóñez toma esse conceito de Alarcos (1994). 
(35a) El decano es quien ha convocado junta para el lunes.

(35b) Junta es lo que ha convocado el decano para el lunes.

(35c) Para el lunes es para cuando ha convocado junta el decano.

Vemos nos enunciados acima que se coloca em $\mathrm{Pl}^{\mathrm{I}}$ os constituintes que se quer enfatizar. As traduções que propomos para as sentenças acima são as seguintes:

(35a') [O reitor é quem convocou reunião para (a) segunda-feira]

(35b') [Reunião é o que convocou o reitor para (a) segunda-feira]

$\left(35 c^{\prime}\right) \quad$ [Para (a) segunda-feira é que o reitor convocou reunião]

Percebemos que, tanto nas sentenças trazidas por Gutiérrez Ordóñez (1997) quanto pelas traduções que propusemos, tratam-se, de estruturas clivadas, como falamos anteriormente. Defendemos, junto com Pezatti (2012), Braga \& Barbosa (2009) e Pinto (2008), que as clivadas são estruturas para marcação de Foco sobreposto a Contraste (Foco Contrastivo), tema que retomaremos, ainda que de maneira rápida, na seção seguinte deste capítulo, na qual falamos sobre a função pragmática de Contraste.

Assim, retomamos as construções com Foco-ser que ocorreram em nosso corpus em PB e que exemplificamos anteriormente para agora, então, propor traduções funcionais ao EP:119

- Ela vai é pra casa das noivas $\rightarrow$ Ella adonde va es a la casa de las novias / Adonde ella va es a la casa de las novias.

- $\quad$ Eu tenho é só vergonha $\rightarrow$ Lo único que tengo es vergüenza. / Vergüenza es lo único que tengo.

- Você usou lá foi esse cartão de crédito do Banco do Brasil aqui? $\rightarrow$ ¿La que usaste allá fue esta tarjeta de crédito (aquí) del Banco do Brasil?

- $\quad$ Eu acidentei foi dia dois $\rightarrow$ Me accidenté el día dos / El día dos fue cuando me accidenté.

119 Agradeço à Maite Celada Echeverría e ao Fernando Legón, que, junto com minha orientadora, me ajudaram a propor as traduções para essas sentenças, que se configuraram com um verdadeiro desafio para todos, aliás. 
As traduções acima nos indicam que a principal estratégia usada em EP, para os casos em que se recorre ao Foco-ser em PB, é algum tipo de sentença clivada (escindida), ${ }^{120}$ ou seja, todas usando um pronome relativo.

Quais seriam, então as maneiras de focalizar um constituinte em EP, sem necessariamente contrastá-lo? Vejamos, antes, a definição de Foco dada por Gutiérrez Ordóñez (1997, p. 34):

De forma semelhante ao que ocorre na óptica, o foco é um ponto no qual coincidem/se juntam os vetores intencionais do emissor. Seu propósito comunicativo costuma ser o de chamar a atenção do receptor com a finalidade de rejeitar uma predisposição contrária ou simplesmente de destacar sua importância no processo informativo no qual se encontram imersos. ${ }^{121}$

Na citação, podemos ver que o autor engloba em um mesmo rótulo o que, na GDF, se separa entre Foco e Contraste (e que em várias vertentes teóricas tem-se chamado de foco contrastivo). Por isso, nós distinguiremos essas duas funções, embora, como já dito, muitas vezes Foco e Contraste (e Tópico) se sobrepõem.

De acordo com Gutiérrez Ordóñez (1997), há cinco possibilidades para marcação de Foco em EP, que são as seguintes: (i) mudança de ordem; (ii) recursos léxicos; (iii) acento de insistência; (iv) reduplicação e (v) estruturas de ênfase (subdivididas em cinco subgrupos, dentre elas as equacionais das qual falamos acima). Apresentaremos nesta seção somente a primeira como realmente marcadoras de Foco, de acordo com a perspectiva teórica que adotamos, e que fazem parte do escopo de nosso trabalho, deixando algumas outras descritas pelo autor para as marcações da função de Contraste e da categoria pragmática de Ênfase, que serão explicadas ainda neste capítulo.

\footnotetext{
120 Outros exemplos de orações clivadas que apareceram em nosso corpus, para marcar a funcionalidade que descrevemos são: *NIE: Eso es lo que hay que mirar (C-ORAL-ROM-efamdl19) e ${ }^{*}$ NIE: Eso es lo que no tengo todavía muy claro (C-ORAL-ROM-efamdl19). Vemos que as estratégias focalizadoras são as mesmas das propostas pelos tradudores de nossas sentenças do PB.

121 Tradução nossa do original: De forma semejante a lo que ocurre en óptica, el foco es un punto en el que confluyen los vectores intencionales del emisor. Su propósito comunicativo suele ser el de llamar la atención del receptor con el fin de vencer en éste una predisposición contraria o simplemente de subrayar su importancia en el proceso informativo en el que se hallan inmersos.
} 


\subsubsection{A ordenação dos constituintes na marcação de Foco}

Como mecanismo de marcação de Foco pela ordenação para constituintes que aparecem pospostos ao Predicado, Pezatti (2014, p. 101) nos traz o seguinte exemplo (36):

\begin{tabular}{|c|c|c|c|}
\hline $\mathbf{P}^{\mathrm{M}}$ & $\mathbf{P F}^{\mathrm{F}-2}$ & $\mathbf{P F}^{\mathrm{F}-1}$ & $\mathbf{P}^{\mathrm{F}}$ \\
& & & $\mathbf{F O C}$ \\
\hline tínhamos & só no primeiro nível & em setenta e sete, & $\begin{array}{c}\text { um milhão e } \\
\text { vinte e seis mil }\end{array}$ \\
\hline
\end{tabular}

Em (36), o constituinte um milhão e vinte e seis mil é argumento de tínhamos e, como vimos anteriormente, ocuparia $\mathrm{P}^{\mathrm{M}+1}$, caso a sentença fosse apenas tínhamos um milhão e vinte e seis mil, e seria apenas um Comentário, cujo Tópico seria retomado do Componente Contextual por meio de uma anáfora zero. No entanto, outros constituintes, que canonicamente ocupariam $\mathrm{PF}$, interromperam a adjacência entre o predicado e seu argumento. Esses constituintes "interruptores" (que no nosso exemplo são os modificadores só no primeiro nível e em setenta e sete) continuam ocupando domínio de $\mathrm{PF}$, mas são então empurrados para posições mais baixas pelo constituinte que exerce a função de Foco e que ocupa, por isso, a posição absoluta. Essas interrupções na adjacência canônica é que trazem um relevo especial ao argumento do predicado.

Em EP essa estratégia também está disponível, como vemos no exemplo seguinte:

(37) *UEL: bueno / pues / que la obra eso / que está muy bien //\$ o sea el argumento está muy bien $/ / \$$ el Shakespeare este / es un tío $/ \$$

*UEL: / $[<]<$ listo $h h h>/ / \$$

*OÑO: lo mismo / le pagan de guionista / en Hollywood una pasta // $\$<h h>/ / \$$

*UEL: $[<]<x x x>/ / \$$ si se enteran / de lo bien que escribe / pues seguro que le fichan // $\$$ (C-ORAL-ROM-efamdl20)

[o mesmo/ lhe pagam como roteirista/ em Hollywood uma grana]

Em (37), o Tópico é retomado anaforicamente (El Shakespeare este) e o constituinte una pasta [uma grana] é argumento do verbo pagar. Logo, sua ordenação icônica seria logo após o verbo (le pagan una pasta), ocupando a posição $\mathrm{P}^{\mathrm{M}+1} \mathrm{e}$ mantendo os modificadores de guionista e en Hollywood em PF. No entanto, para dar 
releve a essa nova informação, o Falante opta por alocá-la na posição absoluta de $\mathrm{P}^{\mathrm{F}}$, atribuindo-Ihe a função de Foco. O esquema de posições de (37), portanto, é o seguinte:

\begin{tabular}{|c|c|c|c|c|}
\hline $\mathbf{P}^{\mathrm{M}-1}$ & $\mathbf{P M}^{\mathrm{M}}$ & $\mathbf{P F}^{\mathrm{F}-2}$ & $\mathbf{P}^{\mathrm{F}-1}$ & $\mathbf{P F}^{\mathrm{F}}$ \\
& & & & FOC \\
\hline le & pagan & de guionista & en Hollywood & una pasta \\
\hline
\end{tabular}

Como vemos, o recurso que acabamos de descrever funciona para a marcação de Foco para constituintes correspondentes sintaticamente aos Objetos da Oração. Falaremos agora um pouco sobre a estratégia de focalização do Sujeito em $E P$, que consiste em posicionar o constituinte focal em $\mathrm{PF}^{\mathrm{F}}$, antecipando para $\mathrm{P}^{\mathrm{I}} \mathrm{o}$ constituinte que, caso fosse apenas um Comentário, ocuparia domínio à direita de $\mathrm{PM}^{\mathrm{M}}$ (o que tradicionalmente seria a anteposição do Objeto). Segundo Gutiérrez Ordóñez (1997, p. 34), "A anteposição ao início da oração de uma sequência que normalmente não ocuparia essa posição é um dos recursos mais usuais."122 O autor se refere a essa estratégia como anteposição focalizadora (anteposición focalizadora) ou tematização (tematización). Segundo ele, a resposta mais natural à pergunta ¿Quién toca el piano? [Quem toca o piano?] seria El piano lo toca Juan [O piano o toca Juan]. Ou seja, a resposta mais típica seria uma sentença com ordem OVS com o seguinte esquema de posições:

\begin{tabular}{|c|c|c|c|}
\hline $\mathbf{P}^{\mathbf{I}}$ & $\mathbf{P}^{\mathbf{1 + 1}}$ & $\mathbf{P}^{\mathrm{M}}$ & $\mathbf{P}^{\mathrm{F}}$ \\
TOP & TOP & & FOC \\
\hline el piano & lo & toca & Juan \\
\hline
\end{tabular}

Se alguém dissesse Juan toca el piano [(O)Juan toca o piano], sem nenhum acento prosódico sobre o termo Juan, teríamos um caso de ambiguidade informacional, já que esse enunciado poderia responder tanto à pergunta anterior como a essa outra: ¿Qué toca Juan? [O que (o) Juan toca?]. O autor conclui, assim, que entre JUAN toca el piano (aqui com acento prosódico em Juan) e El piano lo toca Juan não há diferença informativa, já que, nos dois casos, independentemente da posição que ocupa na sentença, o constituinte Juan seria o Foco (que o autor chama

122 Tradução e adaptação nossa do original: La anteposición a la cabecera de la secuencia de un elemento al que no le corresponde esta distribución es uno de los medios más socorridos. 
de aporte ou rema) e o constituinte el piano seria o Tópico (que ao autor chama de soporte ou tema). ${ }^{123}$ Aqui fica claro que o Foco é justamente a parte da sentença que preenche a lacuna de informação expressa pelo pronome interrogativo da pergunta (ou, nos termos da GDF, pelos operadores de llocução), como afirma Zubizarreta (1999). ${ }^{124}$

Acreditamos que uma estratégia semelhante a essa são as estruturas passivas de ser + particípio, em ambas as línguas: El piano es tocado por Juan / O piano é tocado pelo Juan. Dentre outras funcionalidades, essas construções parecem ser, também, um recurso para alocar o constituinte focalizado em $\mathrm{PF}$. Apesar de as construções passivas não estarem contempladas em nossos objetivos de pesquisa, voltaremos a falar um pouco delas mais adiante. Por enquanto, basta-nos dizer que Araújo Jr. (2007, 2013, 2014), ao estudar contrastivamente as sentenças passivas em PB e em EP, concluiu que, apesar de serem estruturas evitadas em ambas as línguas, quando ocorrem, tendem a ocultar os Agentes. Quando, no entanto, esses Agentes são expressos nas passivas com ser + particípio, que são as que trazemos aqui, a tendência é tematizar os Pacientes e rematizar os Agentes. Nos termos da GDF: Sujeito Inativo com função de Tópico ocupa $\mathrm{P}^{\mathrm{I}}$ (o piano / el piano), enquanto Ator com função de Foco ocupa PF (Juan). Claro que nossa aproximação dessas estruturas passivas com as ativas dos tipos que descrevemos acima (El piano lo toca Juan) é muito mais cognitiva que sintática: sentimos que Juan, na passiva, corresponde semanticamente ao Juan da ativa, pois ambos são os termos que indicam os Agentes (Atores). Essa semelhança semântica e cognitiva é uma das razões para que justamente se prefira usar uma sentença ativa do tipo que apresentamos (OVS) como forma de evitar o uso da construção passiva em EP. Porém, obviamente, nas passivas não estamos falando de focalização de Sujeitos. Ainda segundo Araújo Jr. (2007, 2013, 2014), as passivas pronominais tendem a rematizar os Pacientes, ou seja, é

\footnotetext{
${ }^{123} \mathrm{Na}$ verdade, Gutiérrez Ordóñez (1997) faz distinção entre aporte e foco: o aporte tem caráter sintagmático e é a parte que carrega a informação nova (o que na GDF identificamos como o Comentário), enquanto o foco tem uma natureza paradigmática e, como dissemos anteriormente, pode ser entendido como uma correção de informação ou destaque de uma informação nova (essa segunda funcionalidade corresponde ao Foco da GDF). Assim, em um enunciado como JUAN toca el piano, o autor defende que o termo Juan é, concomitantemente, aporte e foco (o que, segundo nossa interpretação, seria um caso de sobreposição de Foco e Contraste).

${ }^{124}$ En la medida en que la pregunta y la respuesta correspondiente comparten la misma presuposición, podemos identificar el foco de una aserción como aquella parte de la aserción que sustituye al pronombre interrogativo en la pregunta correspondiente (ZUBIZARRETA, 1999, p. 4225).
} 
outra estratégia para focalizar constituintes alocando-o em $\mathrm{PF}$, em estruturas como Vende-se casa ou Se vende casa, em que o termo casa é o Foco nas duas línguas. Voltando às sentenças de EsCos [+dinâmicos], no entanto, que são as que selecionamos para análise, retomemos o exemplo El piano lo toca Juan: note-se que, ao colocar em $\mathrm{P}^{\mathrm{I}}$ o termo que é Tópico e retomá-lo obrigatoriamente com pelo clítico lo (duplicando o Tópico, portanto), automaticamente o constituinte com função de Foco passa a ocupar PF. Vale observar, porém, que, como vimos na seção anterior, a duplicação do Tópico não é uma estratégia exclusiva para marcação de Foco, já que esse Tópico duplicado pode ter em sua sequência apenas um Comentário (como nos vários exemplos que demos como Los yogures Danone los he visto hace muchísimos años). Aqui, novamente, o que determina a função pragmática dos constituintes são o contexto e as intenções dos Falantes, muito mais que as estruturas gramaticais usadas, que podem ser polivalentes.

O percurso analítico de Gutiérrez Órdóñez, que apresentamos acima, é muito parecido com o de Zubizarreta (1999), segundo a qual a ordem VOS em espanhol tem duas propriedades relevantes:

1. VOS não é ambígua do ponto de vista da divisão 'foco/pressuposição': o sujeito, e somente ele, é foco;

2. VOS não é ambíguo do ponto de vista prosódico: o acento nuclear neutro deve recair sobre o sujeito (ZUBIZARRETA, 1999, p. 4233). ${ }^{125}$

Vemos que, em Gutiérrez Ordóñez (1997), propõe-se que a ordem OVS seja a focalizadora de Sujeito. Já Zubizarreta (1999) fala de uma ordem VOS para cumprir essa finalidade. Como exemplo, a autora traz a seguinte pergunta:

¿Quién se comió un ratón?

[Quem devorou um rato?] ${ }^{126}$

[Quem um rato devorou?]

A pergunta (38), segundo a autora, pode ser respondida por (39):

\footnotetext{
125 Tradução nossa do original: 1. VOS no es ambiguo desde el punto de vista de la división 'foco/presuposición': el sujeto, y solamente este, es foco. 2. VOS no es ambiguo desde el punto de vista prosódico: el acento nuclear neutro debe recaer sobre el sujeto.

126 Traduzimos se comió por devorou porque, em E, há uma diferença entre comer e comerse: no segundo caso, quando se usa o dativo se junto com o verbo, o que se expressa é totalidade, uma conotação de gula, como se se quisesse dizer comeu tudo sozinho.
} 
Se comió un ratón el gato.

[Devorou um rato o gato]

[O gato (devorou um rato)].

Mas essa mesma estrutura Se comió un ratón el gato não poderia responder à pergunta ¿Qué ocurrió? [O que aconteceu?], já que, nesse caso, se esperaria uma sentença inteiramente focal e, por isso, o Sujeito apareceria no início da sentença e não no final, já que, no final, apenas ele seria o constituinte focalizado. A resposta para ¿Qué ocurrió?, portanto, provavelmente fosse El gato se comió un ratón (SVO) [O gato devorou um rato].

O exemplo (40) de nosso corpus é um caso de focalização do Sujeito, o que leva à ordem VS:

*PIE: quién estuvo ?\$

*PAZ: estuvo / la miss España / que salió <nueva $>$ /

*PIE: $[<]<j a h ! /$ sí> //\$ [ah, sim] (C-ORAL-ROM- efamdl33)

[ ${ }^{\star} \mathrm{PIE}:$ Quem esteve? / Quem estava?

${ }^{*}$ PAZ: Esteve a miss Espanha, que saiu nova/ Estava a miss Espanha, que surgiu nova.

${ }^{*} \mathrm{PIE}:$ ah, sim]

O que estamos dizendo aqui, portanto, é que, na verdade, a distinção não está na ordem OVS, VOS ou VS, mas sim na posição final do constituinte focalizado (nos casos de focalização dos Sujeitos, eles é que devem se manter em PF, portanto). Isso nos indica que, em EP, assim como em PB, constituintes focais ocupam PF, e, como vemos nos exemplos abaixo, se os constituintes focalizados forem os argumentos com função de Objeto, eles se manterão em sua ordem icônica, à direita dos predicados (o que constitui casos de focalização in situ), quando se tratar de respostas a perguntas:

- ¿Qué has comido de especial hoy?

- Pues he comido pan de muerto y calaveritas de azúcar. ${ }^{127}$

[O que você comeu de especial hoje?

(Pois) comi pão de morto e caveirinhas de açúcar].

127 Aqui, trata-se de uma pergunta que fizemos a um mexicano, por meio do aplicativo Whatsapp, com relação à celebração do Dia dos Mortos (02 de novembro). 
*UEL: pero con quién quedaste / al <final> ?\$

*OÑO: [<] <pues> / quedé con Vicky //\$ (C-ORAL-ROM-efamdI20)

[*UEL: mas com quem você ficou afinal?

*OÑO: (pois) fiquei com (a) Vicky]

Concluímos, assim, que a estratégia de mudança de ordem descrita por Gutiérrez Ordóñez (1997) se restringe à focalização de Sujeitos, que, como vimos, se realiza em PB por meio de sentenças clivadas. Acreditamos que esse recurso seja mais um indício da não topicalização dos Sujeitos em Espanhol, como afirmamos na seção anterior. Essa estratégia não está disponível no PB pelas próprias limitações semânticas que já comentamos: como o PB não dispõe de marcas morfossintáticas que diferenciem Sujeitos de Objetos (ou Atores de Inativos), a posição é o único meio de estabelecer essas funções (alocando Sujeitos/Atores à esquerda e Objetos/Inativos à direita do predicado). Como essa restrição não se aplica ao EP, devido à possibilidade da marcação morfossintática dos Inativos por meio da preposição a, essa língua torna-se mais flexível quanto à ordenação dos Sujeitos.

As sentenças clivadas também estão disponíveis em EP, tanto para marcação de Sujeitos como para marcação de Objetos, Predicados ou outros constituintes, embora estudos como os de Pinto (2008a, 2008b) tenham demonstrado várias assimetrias também quanto aos usos dessas estruturas entre o PB e o EP.

Queremos acrescentar algumas ideias sobre a estratégia de ordenação para marcação de Objetos focais em EP que apresentamos (a de posicionar os Sujeitos em $\mathrm{P}^{\mathrm{F}}$ ). Antes, porém, de mostrar nossos exemplos, nos basearemos no raciocínio, outra vez, de Gutiérrez Ordóñez (1997, p. 36), quando compara as seguintes sentenças:

$$
\begin{aligned}
& \text { El piano lo tocará Juan. } \\
& \text { EI PIANO Ø tocará Juan. }
\end{aligned}
$$

Somente (44) poderia ser a resposta a ¿Qué tocará Juan? [O que o Juan tocará?]. Ou seja, em (44), o constituinte el piano é o Foco (ocupando $\mathrm{P}^{\prime}$ ) e não é retomado por um clítico, enquanto o constituinte Juan é o Tópico. Já (43) responde a ¿Quién tocará el piano? [Quem vai tocar o piano?], tendo, desse modo, o constituinte Juan como Foco (ocupando PF) e el piano como Tópico. Por ser Tópico, em (43) o termo piano precisa ser retomado pelo clítico (lo). Algo importante a se destacar aqui 
é que, como vemos pelas letras maiúsculas da palavra piano em (44), esse recurso de alocar Foco em P', segundo Gutiérrez Ordóñez (1997) deve sempre ser usado concomitantemente ao recurso de marcação prosódica. Segundo nosso ponto de vista, trata-se, portanto de um recurso muito mais prosódico que propriamente de ordenação. Em resumo, "Quando nas anteposições focalizadoras o que se translada ao início é um implemento ou um complemento, essas funções não vêm reduplicadas por meio de um pronome átono" (GUTIÉRREZ ORDÓÑEZ, 1997, p. 36). ${ }^{128}$

A sentença (43) revalida o que dissemos na seção anterior, sobre os Tópicos duplicados. De maneira esquematizada, podemos expressar assim o que acabamos de desenvolver sobre as possibilidades de interpretação discursiva da ordem OVS em EP, considerando para a posição de Foco em $\mathrm{Pl}^{\mathrm{I}}$ a concomitância com o uso da marcação prosódica:

\begin{tabular}{|l|l|l|l|}
\hline Constituinte & Clítico & Função pragmática & Posição \\
\hline
\end{tabular}

(a)

\begin{tabular}{|c|c|c|c|}
\hline $\mathrm{O}$ & $\varnothing$ & $\mathrm{FOC}$ & $\mathrm{P}^{\mathrm{I}}$ \\
\hline $\mathrm{S}$ & - & TOP & $\mathrm{P}^{\mathrm{F}}$ \\
\hline
\end{tabular}

(b)

\begin{tabular}{|c|c|c|c|}
\hline $\mathrm{O}$ & + & TOP & $\mathrm{P}^{\mathrm{I}}$ \\
\hline $\mathrm{S}$ & - & FOC & $\mathrm{PF}^{\mathrm{F}}$ \\
\hline
\end{tabular}

Esquema 21 - Interpretação discursiva da Ordem OVS em EP

É importante assinalar que a função Contraste, que veremos na seção seguinte, pode coincidir e recair tanto sobre Tópicos quanto sobre Focos e, portanto, no esquema acima, poderia ser acrescentada essa terceira função pragmática às já indicadas. Assim, em (43), poderíamos ter um Foco + Contraste, indicando que não é Maria, por exemplo, quem tocará o piano, mas sim Juan; enquanto em (44) o Foco +

128 Tradução nossa do original: Cuando en las anteposiciones focalizadoras lo que se traslada al inicio es un implemento o un complemento estas funciones no vienen reduplicadas por medio del átono pronominal. 
Contraste indicaria que é um piano o que o Juan toca (e não outro instrumento, por exemplo). Vejamos agora alguns exemplos de nosso corpus retomados de capítulos ou seções anteriores, agora com a adição da informação sobre o Foco:

*NIE: pero cómo la calculas \$

*PAC: con $m$ dólar / igual a dos $m$ dólar más uno $/ / \$$

${ }^{*} N I E$ : pero tú $+\$$ éste [I/I] el primer $m$ dólar ...\$

*PAC: el primer $\boldsymbol{m}$ dólar se lo das tú aquí //\$ $m$ dólar / es igual a cero //\$ (C-ORAL ROM-epubdl5)

(46) $\quad$ *LUZ: $[<]<$ yo estaba encantada> / fijate / con esta chica / pero nada / de repente se ve que le ha salido algo / y [/ y / como son tan tímidas / y tan ...\$

*DOL: no dicen ni pío $/ / \$<$ <ésta> +\$

*LUZ: $[<$ < <no me> dijo ni mu / me dejó plantada / estaba preocupada / creía que la había pasado algo / pero se la encontró hhh mi hijo en el autobús / dio la casualidad / y no le había pasado nada //\$ < simplemente se fue> // \$ (C-ORAL-ROM epubdl07)

(47) *PAC: Tolueno / Sileno ...\$ como / desde biferilo / xxx / hay un montón de / compuestos tóxicos //\$ y / la mayoría de estos se los comen / las seudómonas //\$ entonces la cosa es / \&comprend +\$ porque lo que pasa es que a ver / nosotros en el laboratorio / conseguimos que \&cre [/] que crezca comiendo Sileno / no (C-ORALROM-epubdl15)

Nesses três exemplos, os constituintes tú, mi hijo en el autobús e las seudómonas são constituintes focais e por isso ocupam $\mathrm{PF}$, mesmo sendo Sujeitos. Em (46) temos um modificador de lugar ocupando a posição absoluta de $\mathrm{P}$, restando $\mathrm{P}^{\mathrm{F}-1}$ para o Sujeito. $\mathrm{E}$, como vimos na seção anterior, os constituintes que ocupam $\mathrm{P}^{\mathrm{I}}$ são Tópicos e, por isso, são retomados por clíticos.

Já os seguintes exemplos têm o constituinte focal em $\mathrm{P}^{\mathrm{l}} \mathrm{e}$, por isso, não são retomados por clíticos:

\%alt: (5) pa

*UEL: $[<]<x x x>/ / \$$ si se enteran / de lo bien que escribe / pues seguro que le fichan $/ / \$$

*OÑO: seguro que le fichan para Hollywood //\$

${ }^{*} U E L:<y>+\$$

*OÑO: [<] <un Oscar> se lleva / vamos //\$ (C-ORAL-ROM-efamdI20)

(49) $\quad$ *PAC: ijoder! //\$ <eso / menuda casa están haciendo > //\$

*PAT: $[<]<y$ han cogido de arriba a abajo $>$ [/]\$

*JOS: [<] <siéntate aquí si >quieres / eh?\$

*PAC: menuda <casa están haciendo> //\$ (C-ORAL-ROM-efamcv05) 
Como podemos constatar, não ocorre a estrutura un Óscar se lo lleva nem menuda casa la están haciendo. A ausência dos clíticos indica que não há retomada anafórica, e, portanto, que os elementos que aparecem em $\mathrm{P}^{\mathrm{I}}$ não são os Tópicos. Outra característica que nos mostra que esses constituintes que ocupam $\mathrm{PI}^{\mathrm{I}}$ não são os Tópicos é a ausência de determinantes especificadores em ambos os exemplos, já que em (48) temos um artigo indefinido (un). Observemos também que em ambas as ocorrências, os Falantes preferiram omitir os Sujeitos/Tópicos, já que poderiam ser retomados do contexto por uma anáfora zero. Em (48), o arquivo de áudio nos mostra que, de fato, parece haver uma proeminência prosódica no constituinte un Óscar ${ }^{129} \mathrm{e}$ em (49) temos a expressão menuda, que serve para enfatizar o constituinte focalizado casa. Ou seja, que nessas duas ocorrências o recurso de alocar Foco em $\mathrm{P}^{\prime}$ teve que ser usado concomitantemente a outros recursos (prosódia ou operador enfático) e não dependeu exclusivamente da ordenação. Gutiérrez Ordóñez fala desse recurso enfático:

Além da marcação prosódica, a língua se vale de recursos léxicos. Existem pistas como baita, lindo, bonito... ou o qué em seus usos de adjetivo exclamativo que contribuem para marcar a focalização. Normalmente vêm acompanhados da entonação exclamativa (GUTIÉRREZ ORDÓÑEZ, 1997, p. 36). ${ }^{130}$

Ainda neste capítulo, falaremos sobre a categoria de Ênfase. No entanto, o exemplo (49) já nos chamou a atenção para o fato de que Ênfase e Foco não são sinônimos, de acordo com a perspectiva teórica que adotamos.

O último assunto que queremos abordar sobre o Foco são os enunciados Téticos, sobre os quais já havíamos adiantado algumas coisas na seção sobre o Tópico. Para eles, abrimos a próxima seção.

${ }^{129}$ A falta de recursos tecnológicos apropriados para fazer uma análise apurada da prosódia nos impede de fazer uma afirmação categórica sobre a proeminência prosódica desse constituinte.

130 Tradução nossa do original: Aparte del acento de insistencia la lengua acude a recursos léxicos. Existen signos como menudo, lindo, bonito... o el qué en sus usos de adjetivo exclamativo que contribuyen a marcar la focalización. Normalmente vienen acompañados de la entonación exclamativa. 


\subsubsection{Ainda os enunciados Téticos}

Como já adiantamos quando falamos sobre os nomes nus, há algumas construções nas línguas que são inteiramente focais, ou seja, destituídas de Tópicos. Vimos que há duas classes básicas universais de Orações, diferenciadas entre si pragmaticamente por seus Moldes de Conteúdo: as Categóricas (ou Categoriais) e as Téticas. A diferença primordial entre esses dois grupos não é percebida em termos sintáticos, mas sim pragmáticos e informativos.

Segundo Pinheiro-Correa (2018, p. 236, baseando-se em Sasse, 1987, p. 522), as línguas têm diferentes maneiras para marcar gramaticalmente essa teticidade, podendo ser por meio da prosódia (como o inglês e o alemão), da ordenação de Palavras (como o espanhol e o italiano) e de construções cindidas (como o francês). Mas, de modo geral, a teticidade é gradiente, já que, quanto mais o enunciado romper com a expectativa sobre o tipo de informação que é esperada pelo interlocutor, mais teticidade ele apresenta.

Ainda segundo Sasse (2006, apud Pinheiro-Correa, 2015), as construções Téticas podem ser de diferentes tipos: anunciativas (subdivididas em transitivas e monoargumentais), de função introdutória, interruptivas, de função descritiva e Téticas explicativas. Não explicaremos cada uma delas, pois o que nos interessa, no âmbito desta pesquisa, é a ideia geral presente em todos os tipos de construções Téticas: a focalidade da sentença. No entanto, comentaremos alguns exemplos trazidos por Pinheiro-Correa (2015) relevantes para a análise do nosso corpus.

Pinheiro-Correa (2015) traz como exemplos de Téticas anunciativas com ordem VS no Espanhol sentenças extraídas de dois filmes argentinos (El secreto de sus ojos, de 2009; e Bombón, el perro, de 2004). ${ }^{131}$ A seguir apresentamos algumas sentenças em $\mathrm{E}$ exemplificadas pelo autor, com suas respectivas dublagens aos PB:

Señorita Secretaria, ¿se ha muerto un santo en el día de hoy?

[Senhora secretária, morreu algum santo hoje?]

¡Vino la modista!

[Chegou a costureira!]

131 O autor faz um estudo comparado das Téticas que aparecem nos dois filmes argentinos citados e em suas respectivas versões dubladas para o PB: O segredo de seus olhos e $O$ cachorro. 
Percebe-se que se manteve a ordem VS em PB, não necessariamente por serem sentenças Téticas, mas sim por se tratar de estruturas com verbos inacusativos (morir/morrer venir/chegar). Prova disso é a diferença de ordenação entre essa outra sentença Tética em $\mathrm{E}$, em que se mantém a ordem VS:

Salí boludo, está toda la policía acá, no te va a pasar nada, ¡dale!

[A polícia tá aqui, não vai te acontecer nada, viu?]

O autor nos chama atenção para o fato de que na dublagem de (52) ao PB, temos uma ordem SV, por não se tratar de um verbo inacusativo (estar).

Como exemplo de Tética com função introdutória, Pinheiro-Correa (2015) apresenta o seguinte par de sentenças, extraídas do mesmo corpus dos dois filmes argentinos:

\section{Ahí está Galván. Quiere hablar con usted.}

[O Galván está aí. Quer falar com você.]

Vemos, novamente, que enquanto o $\mathrm{E}$ recorre à ordem VS, o PB recorre à ordem SV, já que, novamente, não se trata de um verbo inacusativo. A inacusatividade, portanto, parece estar diretamente relacionada à ordem VS em PB, mas não necessariamente à ordem VS em $E$, que parece usar outros critérios. Pinheiro-Correa (2015) argumenta que essas são estruturas Téticas pois, apesar de o personagem ser conhecido pelos demais personagens, não é esperado que haja uma menção a ele naquele contexto. Aqui, nossa interpretação difere um pouco da de Pinheiro-Correa (2015), pois como mostraremos ainda nessa seção, nós interpretaríamos um enunciado como (53) como semi-tético. O exemplo dado pelo autor, no entanto, nos vale como uma amostra de que a ordem VS é muito mais frequente em $\mathrm{E}$ que em $\mathrm{PB}$, como comprovamos em nosso corpus.

Há muitas discussões sobre a estrutura argumental das construções Téticas: para Lambrecht (2000) e Sornicola (1995), por exemplo, há uma relação direta entre teticidade e monoargumentalidade. Já Smit (2010, apud PINHEIRO-CORREA, 2018) não faz essa associação, e Sasse (2006) diz que a monoargumentalidade não deve ser confundida nem com intransitividade nem com monovalência, já que muitas línguas que alternam as ordens SV e VS não são muito sensíveis à 
monoargumentalidade. Nós adotamos, neste trabalho, a perspectiva de PinheiroCorrea (2018) e assumimos que as construções Téticas não estão restritas às sentenças monoargumentais:

[...] a monoargumentalidade não é conditio sine qua non para a teticidade, uma vez que considerar Téticas somente as sentenças monoargumentais equivale a apor um critério semântico prévio à análise pragmática, que é o que de fato determina a estrutura informativa da asserção, o que enviesa os resultados, a nosso ver. Construções transitivas podem ter o status de Téticas se forem enunciadas, por exemplo, sem contexto prévio, já que, neste caso, constituem asserções inteiramente remáticas (PINHEIRO-CORREA, 2018, p. 237).

Ainda sobre a questão da monoargumentalidade em construções Téticas nas línguas, de modo geral, constatou-se o seguinte:

Entre as línguas que alternam entre SV e VS pesquisadas no estudo sobre a ordem VS, a monoargumentalidade pode ser vista às vezes, como uma tendência estatística, mas não, como uma restrição gramatical. Algumas línguas não são muito sensíveis à monoargumentalidade; (...) (SASSE, 2006, p. 278, apud PINHEIROCORREA, 2015, p. 202).

Em seus estudos, Sasse (2006) concluiu que o Espanhol é uma língua cuja teticidade é bastante sensível à monoargumentatividade.

Para o PB, Kato (1989) propõe que, a ordenação de Palavras é um mecanismo para diferenciar sujeitos tópicos de sujeitos não tópicos, sendo que enunciados como o pneu furou teria um sujeito tópico (e que, segundo a perspectiva que estamos adotando aqui, seria uma construção categorial), em contraste com o enunciado furou o pneu, em que o sujeito é não tópico (e, que, segundo nossa perspectiva, constitui um enunciado Tético).

Segundo Pezatti (2012, p. 381), as construções categóricas contribuem para o avanço do discurso, enquanto as Téticas "[...] contribuem para a descrição ou montagem do cenário no avanço do Discurso [...]”. A pesquisadora defende que, nos moldes da GDF, as construções Téticas ocupam $\mathrm{P}^{\mathrm{F}}$, já que, como vimos, essa é a posição que abriga constituintes com função de Foco em Português. Pezatti (2012) restringe as construções Téticas às construções de Propriedade Configuracional de predicação Zero e de Um lugar, ou seja, aquelas com verbos intransitivos ou 
monoargumentais, citando exemplos como começou a relampejar e aconteceram vinte e um, vinte e uma erupção. Ainda segundo Pezatti (2012), a ordem não marcada das construções Téticas no PB é a VS.

No entanto, como dissemos anteriormente, defenderemos, com autores como Pinheiro-Correa $(2015,2018)$ e Martínez Caro (2008), entre outros, que a Propriedade Configuracional não é o fator que determina se uma sentença é Categórica ou Tética. Pensamos que essa decisão teórica vai ao encontro do que a própria GDF preconiza: a supremacia da Pragmática sobre a Semântica e a Sintaxe. Além disso, pensamos que se mantém, com isso, o conceito de Foco que adotamos aqui. Portanto, diferentemente do que autores como Pezatti (2012, 2014) defendem, de que construções Téticas têm uma ordem VS, acreditamos que sentenças com ordem SV também possam ser interpretadas como Téticas, de acordo com o contexto em que aparecem e com a intenção comunicativa dos Falantes. Assumimos, desse modo, a postura de Pinheiro-Correa (2018, p. 240) ao dizer que:

Observando a definição de Pezatti $(2012,2014)$ chega-se à conclusão de que as sentenças Téticas por ela descritas estão diretamente associadas às construções com verbos meteorológicos, às construções apresentativas e às denominadas inacusativas, caracterizadas por serem monoargumentais com sujeitos não agentivos. Fica subentendido que todos os verbos de dois ou mais lugares, nas definições da autora, correspondem necessariamente a sentenças categóricas. Essa definição é contrária àquelas presentes em Sasse (1987) e Lambrecht (2000).

A partir do estudo das construções Téticas, comparando os diálogos originais dos dois filmes argentinos com suas dublagens ao português brasileiro PinheiroCorrea (2015) contatou que (i) sentenças Téticas do espanhol eram caracterizadas pela ordem VS e dubladas para o PB com a ordem SV, com exceção das construções com verbos inacusativos; e (ii) em PB, os Sujeitos não topicais, marcados nos diálogos originais em espanhol no caso dativo foram dublados usando-se Sujeitos nominativos, na ordem SV, mesmo em contextos não agentivos.

Em 2018, o pesquisador fez um novo estudo, comparando 48 manchetes de quatro jornais, sendo dois deles brasileiros e dois argentinos (sendo 24 manchetes em cada idioma). Os resultados foram os seguintes: Nas manchetes argentinas, 3 foram de sentenças categóricas, 19 de Téticas e 2 que o autor não classificou. Nas manchetes brasileiras, também apareceram 19 Téticas e apenas 5 Categóricas. 0 
autor constatou ainda que nos dois idiomas as Categóricas eram expressas pela ordem SV. Nas manchetes argentinas, as 3 únicas ocorrências de sentenças Categóricas se deram com um Sujeito Tópico já bastante notoriamente conhecido pelos leitores, por se tratar de assuntos bastante divulgados pela mídia naquele período (lembremos os exemplos de Pinheiro-Correa (2018) que demos anteriormente sobre as duas notícias a respeito do eclipse solar).

Pinheiro-Correa (2018) constatou que, em seu corpus, todas as sentenças Téticas em espanhol eram formadas por um verbo na terceira pessoa do plural ocupando a posição inicial e sem a presença de um constituinte com a função sintática de sujeito (ou seja, 100\% de suas ocorrências foram com sujeitos indeterminados). Diferentemente, em PB, as sentenças Téticas, em sua totalidade, estavam configuradas com a ordem SV. Vejamos esses pares de manchetes analisadas pelo pesquisador:

(54a) Jornal do Brasil: Chefe do ETA é preso em operação policial.

(54b) O Globo: Polícia da França prende líder militar do ETA.

(54c) La Nación: Detienen en Francia al jefe del aparato militar de ETA. (Detêm na França ao chefe do grupo militar de ETA).

(54d) Clarín: Detienen en Francia al máximo dirigente de ETA. (Detêm na França ao maior dirigente de ETA).

Os exemplos acima mostram que, em PB, manteve-se a ordem sintática SV, o que indica que essa é a ordem preferida em $\mathrm{PB}$, tanto para construções Categóricas como para Téticas, enquanto em E preferiu-se usar a ordem VO e os referentes equivalentes aos Sujeitos das sentenças em PB foram expressos como Objetos (complementos verbais) para indeterminar o Sujeito Agente. ${ }^{132}$ Segundo PinheiroCorrea (2018), estruturas como (54c) e (54d) são recursos gramaticais destopicalizadores, disponíveis na língua espanhola.

Veja-se, ainda, que (54a) é uma Oração passiva analítica. Como já mostrado em estudos como os de Araújo Jr. (2007, 2013, 2014), as construções passivas têm baixa frequência quando comparadas às construções ativas, tanto em PB como em E. No entanto, quando ocorrem, são mais frequentes em PB que em E, e apenas em

132 Aqui, mantemos as nomenclaturas agente/paciente, amplamente usada na literatura sobre as orações ativas/passivas, inclusive por Araújo Jr., embora saibamos que, de acordo com a GDF, as funções semânticas são Ativo, Inativo e Locativo, como já explicamos em outro momento. 
determinados gêneros textuais (os mais associados a funções informativas, tais como jornais, revistas, folhetos, etc.), uma vez que em E prefere-se usar outras estratégias para evitar a passiva, como, por exemplo, a construção de uma oração ativa com sujeito indeterminado, como ocorre em (54c) e (54d).

Segundo nosso ponto de vista, em PB também ocorre o que Pinheiro-Correa (2018) constatou em seu corpus sobre as Téticas em espanhol: coloca-se um verbo na terceira pessoa do plural ocupando a posição inicial e sem a presença de um constituinte com a função sintática de Sujeito (ou seja, uma construção com sujeito indeterminado, segundo a gramática normativa). Isso nos mostra que essa também é uma possibilidade em PB (apesar de não ter aparecido no corpus do pesquisador). Se pensarmos em sentenças bastante usuais desse tipo em PB, como ligaram pra você ou roubaram minha bolsa, veremos que claramente se tratam de enunciados Téticos.

Nós estamos de acordo, portanto, com a interpretação de Pinheiro-Correa (2018), ao considerar todas essas sentenças inteiramente como focais (sem Tópicos, portanto). Assim, a única marca gramatical do PB que, ao menos nesse gênero textual, poderia apontar para não topicalização dos constituintes que ocupam $\mathrm{P}^{\prime}$ é a falta de determinação (especificamente de artigos definidos) acompanhando-os. Nossa conclusão é que (54a) e (54b) se diferenciam por suas estruturas sintáticas e semânticas, mas não por seus Moldes de Conteúdo (ou informatividade). Sendo assim, a partir dos exemplos dados em (54), concluímos que há recursos gramaticais semelhantes em ambas as línguas para a expressão de sentenças Téticas, que se diferenciam apenas por suas frequências de usos em cada língua. Assim, vemos que os mesmos recursos estão disponíveis nas duas línguas: (i) ordem VS; (ii) verbo na terceira pessoa do plural com apagamento do Sujeito Agente, em uma ordem VO; (iii) colocação de um nome nu em $\mathrm{P}^{\mathrm{I}}$, como vimos no exemplo sobre o eclipse solar, na seção em que falamos sobre o Tópico. Os recursos são os mesmos nas duas línguas, portanto. O que as diferencia é o seguinte: (i) o PB prefere colocar um nome nu em $\mathrm{P}^{\mathrm{I}}$; enquanto o $\mathrm{E}$ prefere usar o verbo na terceira pessoa do plural, ou seja, indeterminar o agente; (ii) a ordem VS é muito mais usada em $E$ que em PB, já que essa ordem, no PB, está mais restrita aos verbos inacusativos.

Ainda que nosso corpus seja bastante diferente dos corpora estudados por Pinheiro-Correa $(2015,2018)$ e por Araújo Jr. $(2007,2013,2014)$, por não se tratar de textos predominantemente informativos, seus estudos nos valem como argumentação de que não é a ordem VS que determina se uma sentença é ou não Tética. Isso 
significa que a escolha da ordem VS no $E$ para a marcação de teticidade é perfeitamente condizente com o que argumentávamos sobre a alocação dos Sujeitos em $\mathrm{P}^{\mathrm{F}}$ para marcação de Foco sobre as sentenças Categóricas. Nossa tese, portanto, é que não é a ordem que determina a teticidade, mas sim a função pragmática que se atribui aos Sujeitos que determina a ordem.

Também estamos de acordo com a conclusão de Pinheiro-Correa (2015) de que o fator mais relevante para a ordem VS, em PB, é o papel semântico dos Sujeitos, e não fatores informacionais e pragmáticos, uma vez que as ocorrências de construções Téticas com ordem VS só apareceram com verbos inacusativos. Isso nos parece muito coerente com o fato de não existir uma marca morfossintática para a função sintática de Objeto em PB, diferentemente do espanhol que, como vimos, pode recorrer à preposição a antecedendo determinados Objetos, especialmente quando são [+específicos] e [+animados]. Já sabemos que essa marcação do Objeto em E permite uma maior flexibilidade de ordenação dos constituintes, já que nenhum Falante interpretaria um Sujeito à direita do predicado como sendo um Objeto. Portanto, "[...] teticidade e ordem de palavras são conceitos não relacionados em PB" (PINHEIRO-CORREA, 2015, p. 218).

Pinheiro-Correa (2015) suspeita que possa haver alguma relação entre modalizadores e marcadores conversacionais e a sinalização das sentenças Téticas do PB. Esse poderia ser um recurso, além da ordem de Palavras e da marcação de caso, para identificar a teticidade em PB. De qualquer maneira, essa hipótese ainda precisa ser investigada. Não o fazemos aqui, pois modalizadores e marcadores conversacionais fogem ao escopo desta pesquisa. Outro fenômeno descrito pelo pesquisador é o uso, em $\mathrm{E}$, de um dativo em uma estrutura ativa de Sujeito indeterminado, o qual reflete na sintaxe seu papel temático de paciente, como em $Y$ esto la tiene así, exemplo novamente extraído pelo autor das falas dos dois filmes argentinos aos quais nos referimos antes (El secreto de tus ojos e Bombón, el perro). Em PB, por sua vez, essa estrutura foi dublada como Por isso ela tá assim, usandose uma sentença Categórica, sem menção explícita ao Sujeito, em um contexto de continuidade tópica.

Vejamos agora como essas constatações e hipóteses sobre teticidade aparecem em nosso corpus. Todos os exemplos que daremos nesta seção referemse a construções com ordem VS, pois são as que nos interessam do ponto de vista da ordenação e porque foram as mais abundantes em nosso corpus. No entanto, 
voltamos a reiterar que essa não é a única maneira de construir sentenças Téticas, como explicamos acima. Acreditamos que, devido aos gêneros textuais que analisamos (conversas e diálogos espontâneos e informais, que muitas vezes mantêm uma estreita relação com narrativas, já que os Falantes contam/relatam eventos), um tipo de sentença Tética que apareceu em nossas análises foi a descritiva. Esse tipo de construção Tética está relacionada ao estabelecimento da cena em que vão se desenrolar os eventos. Vejamos algumas das ocorrências que encontramos de sentença Tética com a ordem VS em nosso corpus. Outra vez aqui a frequência dessa estrutura foi muito maior em EP que em PB, já que em PB as únicas ocorrências encontradas foram a que reproduzimos em (55) e (56):

*LUZ: <tava> // tava úmida / \&he / a coisa // agora não // *LAU: <é> //

*LUZ: <ressecou> mesmo // ai / lá vem outro caminhão // (C-ORAL-BRASILbfamdl03)

*BRU: chegou correio pra ela // (C-ORAL-BRASIL-bfamcv22)

O contexto de (55) são dois amigos conversando sobre a paisagem e o trânsito enquanto viajam de carro. Observamos que o termo outro caminhão, sendo o Sujeito da Oração e aparecendo à direita do predicado descreve uma cena, um evento: um elemento que surge no discurso, novo, sem função anafórica. O mesmo ocorre em (56), cujo contexto são colegas assistindo à cena de um filme e comentando que chegou correio para uma das personagens. Toda a sentença em (55) e (56), portanto, é focal e está ocupando PF. Sentenças como essas, segundo Sasse (2006, apud PINHEIRO-CORREA, 2015, 2018), seriam construções Tético-Apresentativas, já que simplesmente apresentam uma nova cena.

Em Espanhol, no entanto, encontramos muitas ocorrências de ordem VS que nos remetem às Téticas. Eis alguns exemplos:

*NAT: no sé //\$ porque después viene un primo mío de / Argentina $1 \$$ *PRI: si //\$ *NAT: / que es también / fisio / como yo //\$ (C-ORAL-ROM-epubdl06)

[vem um primo meu da Argentina] 
Em (57) observamos que o Sujeito aparece indeterminado pelo artigo un e pela posposição do possessivo mío: essa construção mostra que se trata se uma informação não pressuposta pela Interlocutora e que, portanto, não é o Tópico da sentença (diferente se a Falante enunciasse viene mi primo de Argentina). Se a escolha, portanto, fosse por mi primo, em lugar un primo mío, poderíamos ter uma sentença com Sujeito Tópico e não mais uma sentença do tipo Tética como a que estamos descrevendo aqui.

Outros dois exemplos de Téticas do nosso corpus em EP são as seguintes:

${ }^{*}$ CRI: / y claro / ves el Salto del Ángel / y te imaginas una cascada de agua impresionante / y claro / caía un chorrito de agua //\$ porque es la época seca //\$ de todas formas / está todo verde / y muy bien //\$ (C-ORAL-ROM-efamcv15)

[caía um fio de água]

(59) $\quad{ }^{*} C R l$ : no hay la humedad suficiente / para que ...\$

*LUI: para hacerlos <bien> //\$

${ }^{*}$ CRI: [<] <empieza> la lluvia ahora //\$ y [/] y fuimos un día / también en avioneta / pero de las buenas $/ / \$$ ya con comandantes y pilotos / profesionales $/ \$$ (C-ORAL-ROM efamcv15)

[começa a chuva agora]

Vemos que em (58) e (59) temos sentenças com verbos inacusativos (caer/cair e empezar/começar), o que, como já dissemos e como vários estudos já apontaram, são verbos que favorecem (embora não determinem), por questões históricas, a ordem VS, tanto em PB como em EP. Essa similaridade entre as duas línguas pode ser percebida pela comparação entre os exemplos em EP e suas respectivas traduções ao PB, que mantiveram a mesma ordenação.

Gostaríamos de comentar mais uma realização da ordem VS em EP:

(60) *LOL: [<] <estudia> muchísimo / con lo cual / \&eh / vamos a clase de solfeo //\$ y entonces están todos / a ver lee la partitura / veinte minutos //\$ (C-ORAL-ROMefamdl01)

Vemos que em (60) o Falante preferiu usar o verbo no tempo presente (están/estão), ao invés de usar um pretérito. Essa característica reforça a função descritiva desse Ato Discursivo em particular, dentro da narração expressa no 
Movimento. Portanto, não interessa predicar algo sobre todos, mas sim mostrar uma cena, um EsCo. A posposição do Sujeito ao verbo estar também é um tipo de construção Tética, aos moldes do que Pilati $(2002,2016)$ classifica como Orações apresentativo-descritivas, seguindo (VOTRE \& NARO, 1999, NASCIMENTO, 1984 e GUÉRON, 1980). Nas palavras da autora, orações como essas:

i) exercem função apresentativa; ii) são usadas em contextos descritivos não em contextos predicativos; iii) seus sujeitos recebem intepretação menos agentiva; iv) podem apresentar sujeitos definidos ou indefinidos; v) quando o sujeito for um NP definido deve ser um NP referencial tanto para o ouvinte quanto para o falante" (PILATI, 2002, p. 66).

Muitas ocorrências com ordenação VS ocorreram em EP com essa mesma funcionalidade de descrever ou de apresentar um EsCo. No entanto, nem todas parecem ser exatamente iguais, segundo nosso ponto de vista. Vejamos o exemplo (61):

//\$ Ilega él / el [/] mi Óscar / lee la partitura / treinta segundos //\$ Ilega la Lola / que es una repipi / menos ayer / que no me la había estudiado e hice el ridículo //\$ (CORAL-ROM-efamdI01)

[chega ele] [chega a Lola]

Nos deparamos aqui com pequeno dilema teórico: parece-nos que sentenças como (57) e (61), por exemplo, entre muitos outros pares que poderíamos ter formado aqui, não podem ser entendidas da mesma maneira. Seria injusto, digamos, simplesmente dizer que as duas, igualmente, são sentenças Téticas. Isso porque em (57) o constituinte que ocupa posição absoluta de $\mathrm{P}^{\mathrm{F}}$ é um constituinte realmente novo, tanto que aparece com o artigo indeterminado (un primo mío). Já em (61), nessa mesma posição temos constituintes altamente determinados e conhecidos tanto pelo Falante como pelo Interlocutor (él/ la Lola). Assim, em (61), esses constituintes aproximam-se muito mais da concepção de Tópico da GDF, como um recurso anafórico que resgata uma informação contida no contexto ou na memória episódica dos Interlocutores, como vimos no capítulo 3. Aproximam-se, mas ainda não podem ser considerados Tópicos, pois, apesar de serem anafóricos, a intenção comunicativa não parece ser comentar nada sobre ele, ou seja, discursivamente não se predica nada sobre eles, já que a intenção dos Falantes é, como dissemos acima, a de 
descrever ou apresentar um EsCo, uma cena. A nosso ver, abrem-se aqui algumas possibilidades interpretativas: (i) considerar essas construções como Téticas e desconsiderar esses diferentes níveis de informação partilhada que os constituintes em $\mathrm{PF}^{\mathrm{F}}$ carregam; (ii) considerar que sentenças como (61) não sejam sentenças Téticas, mas sim Categóricas, e que o Sujeito em $\mathrm{PF}^{\mathrm{F}}$ corresponderia ao Tópico, enquanto o Predicado, ao Foco (e nesse caso, o EP teria muito mais Tópicos ocupando posições diferentes de $\mathrm{P}^{\mathrm{I}}$ ); (iii) considerar a existência de uma categoria que seria um semi-Tópico, ou seja, que é conhecido e anafórico, mas sobre o qual não se predica nada. É essa terceira opção interpretativa que adotaremos. A natureza de semi-Tópico justificaria seu posicionamento à direita do predicado, a fim de diferenciá-lo do Tópico "verdadeiro", que tende a ocupar PI nas duas línguas.

Parece-nos, portanto, que seria coerente criar uma nova nomenclatura para referir-se a esse grupo de enunciados que contenham um semi-Tópico em suas estruturas. Nós sugerimos o termo sentenças semi-Téticas, para denotar um caráter de gradualidade entre as Téticas e as Categóricas. É essa terceira possibilidade interpretativa que decidimos adotar neste trabalho para construções dos tipos (61) e dos tipos (62) e (63), que mostramos a seguir:

${ }^{*} E L E:$ / a ver $/ / \$$ lo de la sierra / fue superagobiante $/ / \$$ porque / estábamos $+\$$ me voy / el día anterior a casa de Aitana // $\$$ y entonces estamos en casa de Aitana / y de pronto se empieza a agobiar Aitana un montón / pensando que vaya plan de mierda I hemos hecho para ir a la sierra //\$

${ }^{*}$ CRI: pero por qué ?\$ estaba muy bien / el plan //\$ (C-ORAL-ROM-efamdI08)

[começa a se incomodar Aitana] / [estava muito bem o plano]

[A Aintana começa a se incomodar] / [o plano estava muito bem]

(63) $\quad{ }^{*}$ CRI: $[<]<$ ibais > con el perro de Aitana / también / no?\$

${ }^{*} E L E:$ sí //\$ hhh //\$ pero porque iba / Ricardo / después de toda la historia ésta que te conté / entonces / (C-ORAL-ROM-efamdI08).

[ia (o) Ricardo]

Propomos incluir nesse grupo das sentenças semi-Téticas as construções com os verbos dicendi nas duas línguas, uma vez que são enunciados tipicamente descritivos dentro de narrações. Segundo Rodrigues (2005) os verbos dicendi são transitivos (do ponto de vista discursivo, por sempre haver um complemento para eles no discurso) e sempre reportam a uma fala. O que se pretende não é, essencialmente, 
mostrar o que foi dito, nem predicar nada sobre o Sujeito que diz, mas sim descrever o fato mesmo do dizer. São exemplos desse grupo:

(64) *MAR: $[<]<$ habría que construir > / una especie de / hhh / cómo le diría yo?\$ como de / cobertizo o algo así //\$ (C-ORAL-ROM-epubdl04)

[como lhe diria eu?]

(65) * $\quad$ LUI: $[<]<$ millones> //\$ millones / dijo tu madre //\$ (C-ORAL-ROM-efamcv02)

[disse sua/tua mãe]

(66) $\quad$ *PAT: $[<]<q u e$ ha abortado> / ya más de una vez //\$ porque dice la abuela / que la veía algún día así //\$ de esto [/] de esto \&ti / \&mm [///] blanca / blanca / blanca / y fatal //\$ (C-ORAL-ROM-efamcv05)

[diz a avó]

Como verificamos em nosso corpus em EP, o verbo que mais ocorreu com sujeito posposto foi justamente o decir (dizer) que, como afirmamos anteriormente, é um verbo do tipo dicendi (na verdade, é o verbo dicendi canônico), como podemos observar no gráfico:

\section{VERBOS COM SUJEITO POSPOSTO NO ESPANHOL PENINSULAR}

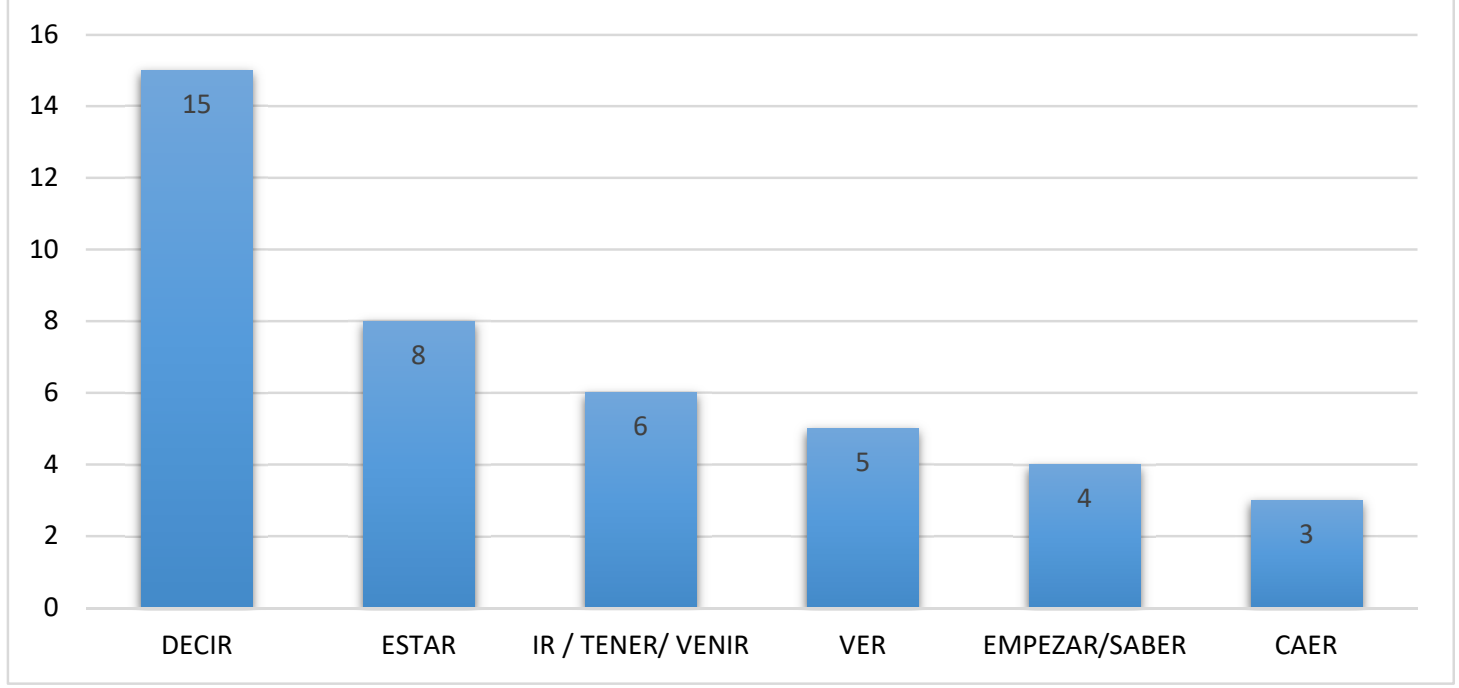

Gráfico 2 - Verbos com Sujeito Posposto mais frequentes nos dados do EP 
Em PB também tivemos ocorrências de sentenças semi-Téticas com o verbo dizer, mas em número muito menor que em EP: apenas 3 (contra 15 em EP), sendo duas delas pronunciadas pelo menos Falante em um mesmo Movimento:

*JUN: <diz ela que> nũ gravou não // C-ORAL-BRASIL-bfamcv15)

(68) *ROG: diz e' que esses dia agora e' nũ pôde vim não porque e' tá [/2] e' tá mexendo com um telhado aí // [159] hora que cabar lá diz e' que ia vim cá // (CORAL-BRASIL-bpubdI01)

Como comentamos no início desta seção, em nosso corpus do PB encontramos apenas 11 ocorrências da ordem VS, com apenas 7 verbos diferentes, sendo que a maioria deles só ocorreu uma única vez, como mostramos no gráfico abaixo:

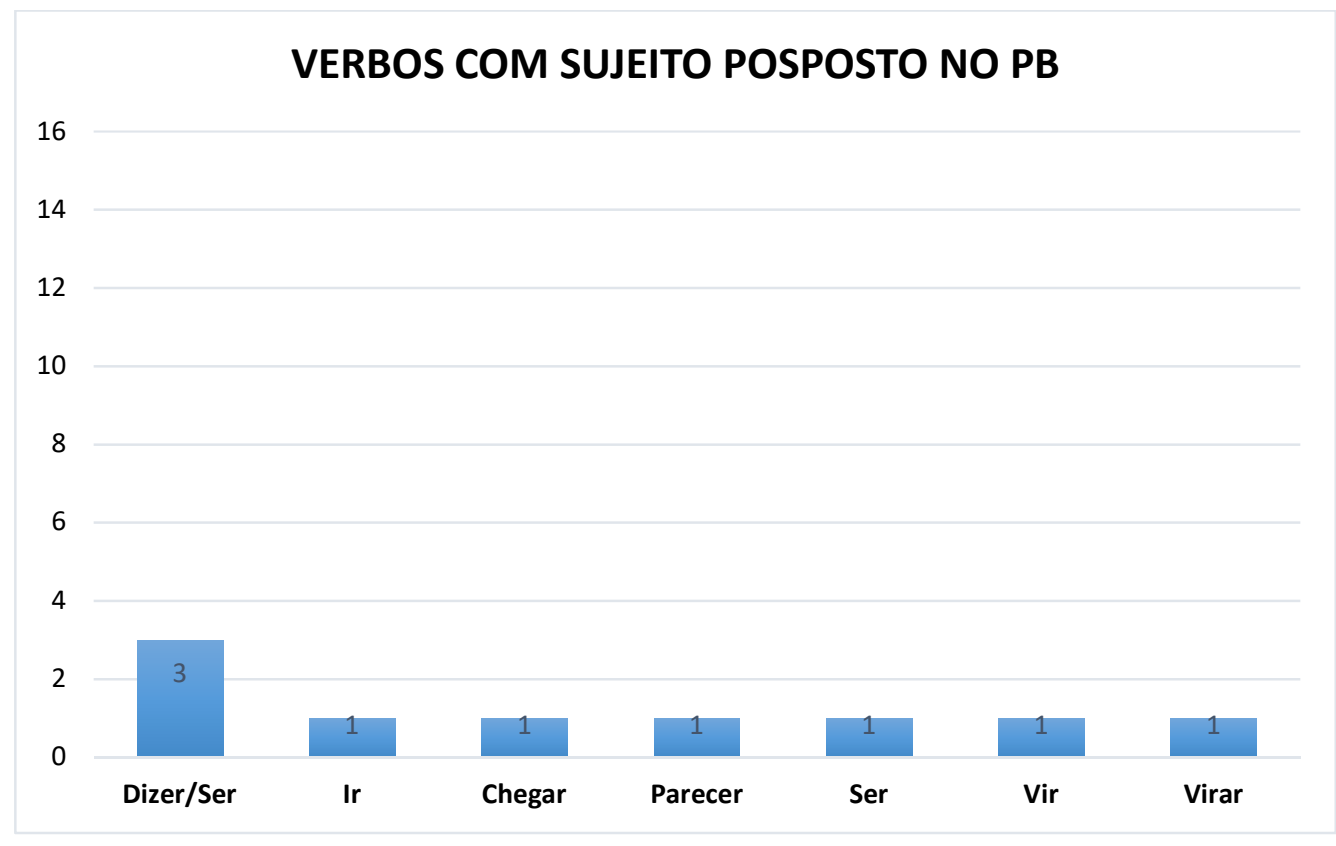

Gráfico 3 - Verbos com Sujeito posposto nos dados em PB

Se comparamos os gráficos 2 e 3, constatamos uma clara diferença na frequência de uso dessa ordenação entre o PB e o EP (e lembremos que no gráfico 2 só aparecem os verbos com 3 ou mais ocorrências de posposição dos Sujeitos e que, portanto, a maioria das ocorrências das 114 que apareceram no corpus, com 51 verbos diferentes, não estão aí registradas). As ocorrências com os verbos chegar e vir, como vimos em (55) e (56), são Téticas. Desconsiderando as 3 ocorrências com 
o verbo ser, por serem construções de identificação e não comporem nosso objeto de análise, restou-nos como semi-Téticas em PB as construções com o verbo dizer, como mostramos anteriormente, e duas mais que apresentamos na seção anterior, sobre Tópico, nos exemplos (7) e (9), que retomamos simplificadamente aqui: Foi ela lá pro shopping / virou uma bola de neve essas atividades. Isso nos mostra, mais uma vez, que o PB tem a ordem VS muito mais restritiva aos verbos inacusativos e aos verbos dicendi.

Para terminar essa seção sobre o Foco e, especialmente, sobre as construções Téticas, gostaríamos de abordar um tipo de construção bastante frequente no EP e atípica do PB, que são as construções com dativos afetados, para as quais abrimos o próximo subitem.

\subsubsection{As construções Téticas em EP com dativos afetados}

Em sua dissertação de mestrado, Gancedo Álvarez (2002) aborda a problemática das construções de dativos na produção de ELE por brasileiros. Segundo a autora, o caso dativo é uma das categorias flexivas do latim, que, junto com as categorias de nominativo, acusativo, genitivo, vocativo e ablativo, indicava a função sintática (e muitas vezes semântica) dos constituintes oracionais. Ao longo do tempo, essas formas de declinações foram desaparecendo, mas ainda deixaram marcas nas línguas românicas, como é o caso da preposição a e dos clíticos le/les em E para os casos de dativo. Com o tempo também, o termo acusativo passou a ser tomado como sinônimo de Objeto Direto, enquanto dativo, de Objeto Indireto.

Do ponto de vista da gramática tradicional, os dativos são as entidades que semanticamente podem expressar um dano, um benefício, um interesse, uma finalidade, um destino, uma origem etc. Esses valores podem ser expressos também por constituintes que não os dativos, mas não entraremos nessa discussão neste momento.

Muitas vezes esses dativos correspondem ao argumento de um predicado de três lugares, como, por exemplo, dar: dar algo a alguém, em que o termo que expressaria o alguém, seria o dativo, ou Objeto Indireto (ou o Locativo, segundo a GDF). Acontece, porém, que em EP muito frequentemente se recorre a estruturas com dativos sem que eles sejam argumentais. São esses casos que nos interessam 
aqui e que, junto com González (1994, 2008) e com Gancedo Álvarez (2002), chamaremos de dativos afetados ou de afetação.

Segundo Gancedo Álvarez (2002, p. 26), esses dativos "[...] supõem a existência de um complemento indireto afetado pela ação do verbo sem a interposição do complemento direto" e podem ter várias funcionalidades, dentre as quais nos interessa destacar os que indicam (i) involuntariedade e (ii) afetação psíquica de construções inacusativas, com verbos como gustar [gostar], encantar [encantar/adorar], preocupar [preocupar], admirar [admirar], molar [agradar], etc.

Não tivemos nenhuma ocorrência do grupo (i) em nosso corpus em E, por isso trazemos aqui alguns exemplos dados por Gancedo Álvarez (2002) e por González (2008):

(69) Se le han roto los anteojos.

[Os óculos dele quebraram]

[Ele quebrou os óculos]. ${ }^{133}$

Vemos que o que caracteriza a sentença (69) é o uso de um predicado com Sujeito inanimado, não-agentivo (Ios anteojos), que afeta um Experienciador construído como Objeto Indireto (dativo le). A involuntariedade da ação é expressa pelo pronome se. Constatamos pelas traduções que essa estruturação não é usual em PB e que nessa língua temos duas possibilidades: (i) para indicar involuntariedade, aloca-se o Sujeito não agentivo em $\mathrm{P}^{\mathrm{I}}$, como Tópico, e usa-se um possessivo (dele), em uma sentença de ordenação SV; ou (ii) para indicar voluntariedade, aloca-se o Sujeito agentivo em $\mathrm{P}^{\mathrm{I}}$, como Tópico, e mantém-se o Objeto em $\mathrm{P}^{\mathrm{M}+1}$, em uma sentença com ordenação SVO. Observe-se que nesta configuração, o clítico (le) do EP desaparece e, em seu lugar, aparece um pronome tônico (ele).

Em PB, portanto, mantém-se a preferência canônica de topicalizar os Sujeitos, sejam eles agentivos ou não, e de mantê-los em PI. Isso confirma a tese de González de que em PB "[...] os tópicos estão cada vez mais assumindo o papel do sujeito e consolidando a estrutura SV(O) na língua" (GONZÁLEZ, 1994, p. 423). Ao contrário, segundo a pesquisadora, há uma clara preferência do $E$ pelas formas átonas, que muitas vezes duplicam formas tônicas, bem como a predileção por estruturas de 
obliquidade por meio das quais o significado verbal recai sobre um Sujeito apenas lógico, mas não sintático.

De acordo com Gancedo Álvarez (2002, p. 35) o E diferencia três estágios de involuntariedade (os exemplos são tomados da autora):

(70a) Luis se rompió los lentes $\rightarrow$ estrutura agentiva com agente

(70b) Se me rompieron los lentes $\rightarrow$ estrutura inagentiva

(70c) Me rompieron los lentes $\rightarrow$ estrutura agentiva sem agente

As traduções que propomos para (70) são as seguintes:

(70a') [(O) Luís quebrou os óculos]

(70b') [Quebraram meus óculos]

(70c') [Meus óculos quebraram]

Vemos que em (70b') a estratégia usada para indeterminar o Sujeito Agente foi colocar o verbo na terceira pessoa do plural com a $\mathrm{P}^{\mathrm{I}}$ vazia. Entendemos que essa construção seja do tipo Tética, ou seja, desprovida de Tópico, assim como (70b) e (70c) em EP. Por outro lado, (70c') pode ser uma construção Categórica, com Sujeito Tópico não agentivo (a depender do contexto de realização). Vejamos que em PB a única marca morfossintática para diferenciar (70b') de (70c') é a ordenação dos constituintes.

O segundo uso dos dativos não argumentais ao qual nos referimos anteriormente são os que indicam afetação psíquica. Vejamos alguns exemplos desse tipo de construção que ocorreram em nosso corpus:

(71) $\quad{ }^{*}$ CRI: $[<]<$ erais $>$ cuatro $/ / \$$ con el perro $/ / \$$

${ }^{*} E L E:$ si $/ / \$$

${ }^{*} \mathrm{CRl}$ : $y$ el perro $/ / \$$ o sea cuatro / $<y$ el perro $>/ / \$$

${ }^{*} E L E:$ [ $\left.<\right]<y$ el perro> / que es gigante / no ?\$ entonces / Ana / todo el tiempo protestando por el perro //\$

${ }^{*}$ CRI: o sea / encima no le molan los perros / claro //\$ (C-ORAL-ROM-efamdl08)

[não lhe agradam os cachorros]

[ela não gosta de cachorros]

*NAT: $[<]<q u e$ se encuentra> mal / o qué?\$ 
*PRI: no //\$ que / ya está bien ahora / ya no la duele tanto la rodilla / y / nada / que la dado por no comer / y dice que no tiene ganas / y que no tiene apetito / y de ahí no hay quién la saque //\$ come muy mal // (C-ORAL-ROM-epubdl06)

[já não Ihe dói tanto o joelho]

[o joelho dela já não dói tanto]

${ }^{*} P R I:<$ te lo dije ?\$ te lo dije>?\$

${ }^{*} N A T:[<]<e l$ último día / que > te dolía toda la espalda / <de haber estado pintando> $1 / \$$

${ }^{*} P R I:[<]<$ sí sí //\$ (C-ORAL-ROM-epubdl06)

[Ihe doíam as costas]

[as costas dela doíam]

Nesses três exemplos, temos uma estrutura diferente das demais que já apresentamos, pois trata-se de EsCos que retratam uma realidade psicológica, interna aos Falantes, ou seja, que descrevem experiências. Segundo Hengeveld \& Mackenzie (2008):

Eventos típicos de experiências envolvem dois participantes, um experienciador e o fenômeno que está sendo experienciado. Observou-se que as experiências tendem a não ter sua própria gramática, mas que sua gramática é modelada a partir daquelas de não-experiências. Como nem o experimentador nem o fenômeno estão envolvidos voluntariamente, podemos esperar que a gramática da experiência seja restrita aos papéis de Inativo e Locativo, e de fato isso é regularmente encontrado (HENGEVELD \& MACKENZIE, 2008, ps. 2359-2542). ${ }^{134}$

Para citar exemplos de EsCos não-dinâmicos de experiência, Hengeveld \& Mackenzie (2008) usam justamente um enunciado em espanhol, com o verbo gustar [gostar] e o comparam com o português. Segundo os autores, o Experienciador é marcado pela preposição a ou por um pronome clítico no caso dativo, como a mí me, a ti te, por exemplo (especificamente nos nossos exemplos temos: le, $l a^{135}$ e te), enquanto o fenômeno experimentado têm a função de Inativo (nos nossos exemplos los perros, la espalda y la rodilla). Em português, diferentemente, o Experienciador é

\footnotetext{
134 Tradução nossa do original: Experiences typically involve two participants, an experiencer and the phenomenon being experienced. It has been observed that experiences tend not to have their own grammar, but that their grammar is modelled upon those of non-experiences. Since neither the experiencer nor the phenomenon is volitionally involved, we might expect that the grammar of experience will be restricted to the roles Undergoer and Locative, and indeed this is regularly found. ${ }^{135}$ Aqui, inclusive, temos um caso de Laísmo, que, segundo o DRAE (Diccionario de la Real Academia Española) é o "Empleo de las formas la y las del pronombre átono para el complemento indirecto femenino, en lugar de le y les" (DRAE, 2017, consulta online). Não nos deteremos em explicar os valores sociais desse uso, pois isso demandaria uma longa explanação que não nos convém agora.
} 
um Inativo e o fenômeno experienciado está marcado com um caso Ablativo (e a preposição de). Veja-se, no entanto, que propusemos duas traduções para cada exemplo em EP: uma mantendo a mesma ordem e mesma estrutura do EP (Experienciador marcado com dativo e fenômeno marcado como Inativo), o que mostra que essa também é uma possibilidade em PB. No entanto, as segundas propostas de tradução nos parecem mais usuais e coloquiais (o que não acontece no $E P$, já que, em nosso corpus, observamos que o mais usual é justamente manter o fenômeno à direita, reservando, na maioria dos casos, a estrutura fenômeno+experienciador para a função de Contraste ou para indicar que o fenômeno é a Orientação do enunciado). É o que ocorre em (74):

*UEL: bueno / pues eso //\$ que / la obra / a Cristina le gustó bastante // (C-ORALROM-efamdl20)

[a obra, a Cristina lhe gostou bastante] [a obra, a Cristina gostou bastante]

No exemplo acima, o constituinte la obra têm função de Orientação (ocupando

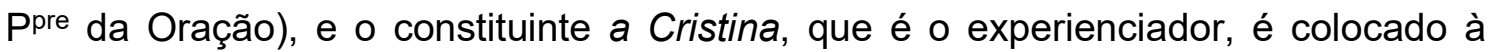
esquerda do predicado para indicar Contraste, já que, no contexto do diálogo, o Falante diz que ele não gostou muito da obra (mas a Cristina, sim). Como, no entanto, não abordamos essas funções ainda, não nos aprofundaremos nessa observação.

Os exemplos (71) a (74) nos mostram, em geral, que esses enunciados que descrevem EsCos de experiências em EP não trazem um Sujeito Tópico, pois a motivação não é falar algo sobre um Sujeito, mas sim, da experiência em si. Em PB, por outro lado, quando dizemos, por exemplo, Eu não gosto de cachorros, estamos predicando sobre um eu (que é o Sujeito Tópico): eu é o assunto, e não a experiência em si mesma. Pensamos que este seja mais um indício da não topicalização dos Sujeitos em EP. Assim, de maneira geral, em EP enunciados de experiência tendem a ser Téticos, enquanto os em PB tendem a ser categóricos (formados por Tópico e comentário).

Tudo o que expusemos nessa longa seção sobre a função pragmática Foco se divide em dois grandes grupos: (1) estratégias para focalizar determinados constituintes e (2) estratégias para não topicalizar determinados constituintes, 
construindo, assim, enunciados totalmente focais (Téticos). Essas ideias podem ser resumidas com os seguintes quadros:

\section{ESTRATÉGIAS DISPONÍVEIS NAS DUAS LÍNGUAS PARA FOCALIZAR UM CONSTITUINTE}

\begin{tabular}{|c|c|}
\hline PB & EP \\
\hline $\begin{array}{ll}\checkmark & \text { Prosódia; } \\
\checkmark & \text { sentenças clivadas; } \\
\checkmark & \text { construções passivas; } \\
\checkmark & \text { posição incomum na sequência } \\
& \text { dos constituintes depois do } \\
& \text { Predicado; } \\
\checkmark & \text { Foco-ser. }\end{array}$ & $\begin{array}{ll}\checkmark & \text { Prosódia; } \\
\checkmark & \text { sentenças clivadas (ou estruturas } \\
& \text { Equacionais); } \\
\checkmark & \text { construções passivas; } \\
\checkmark & \text { posição incomum na sequência } \\
& \text { dos constituintes depois do } \\
& \text { Predicado. }\end{array}$ \\
\hline
\end{tabular}

Esquema 22 - Estratégias de Focalização em PB e em EP

Dentre essas estratégias, escolhemos analisar as sentenças simples de EsCos [+dinâmicos]. O que significa que não analisaremos as clivadas nem as passivas. E como nosso estudo recai sobre fatores de ordenação, também excluímos, neste momento, as análises que considerem exclusivamente os recursos prosódicos. É importante ressaltar que, muitas vezes o Foco coincidirá com a função de Contraste, que explicaremos logo mais adiante. 


\section{ANÁLISE COMPARATIVA DAS ESTRATÉGIAS USADAS}

\begin{tabular}{|c|c|c|}
\hline \multicolumn{3}{|c|}{ PB } \\
\hline Intenção & Estratégia(s) & Exemplos \\
\hline $\begin{array}{l}\text { Focalizar Objetos (que } \\
\text { normalmente ocupariam } \\
\text { posição relativa à direita } \\
\text { de } \mathrm{PM}^{\mathrm{M}} \text { ) ou constituintes } \\
\text { que normalmente } \\
\text { ocupariam } \mathrm{P}^{\mathrm{F}} \text { (como } \\
\text { modificadores) }\end{array}$ & $\begin{array}{l}\text { (1)Foco-ser } \\
\text { (2)Alocar o constituinte } \\
\text { focalizado em posição } \\
\text { absoluta de PF } \\
\text { (3)Clivagem } \\
\text { (4)Passiva }\end{array}$ & $\begin{array}{l}\text { (1) Eu tenho é só vergonha } \\
\text { (2) Tínhamos, só no primeiro } \\
\text { nível, em setenta e sete, } \\
\text { um milhão e vinte e seis mil } \\
\text { (3) É piano que o Juan toca }{ }^{136} \\
\text { (4) O piano é tocado por Juan }\end{array}$ \\
\hline Focalizar Sujeitos & $\begin{array}{l}\text { (1) Prosódia } \\
\text { (2) Clivagem }\end{array}$ & $\begin{array}{l}\text { (1) O JUAN toca piano. } \\
\text { (2) Quem toca piano é o Juan }\end{array}$ \\
\hline
\end{tabular}

Esquema 23 - Estratégias de focalização usadas em PB

\begin{tabular}{|c|c|c|}
\hline \multicolumn{3}{|c|}{ EP } \\
\hline Intenção & Estratégia(s) & Exemplos \\
\hline $\begin{array}{l}\text { Focalizar Objetos (que } \\
\text { normalmente ocupariam } \\
\text { posição relativa à direita } \\
\text { de } \mathrm{P}^{\mathrm{M}} \text { ) ou constituintes } \\
\text { que normalmente } \\
\text { ocupariam } \mathrm{P}^{\mathrm{F}} \text { (como } \\
\text { modificadores) }\end{array}$ & $\begin{array}{l}\text { (1) Clivagem } \\
\text { (2) Alocar o constituinte } \\
\text { focalizado em posição } \\
\text { absoluta de } \mathrm{PF}^{\mathrm{F}} \\
\text { (3) Passiva } \\
\text { (4) Ordem (O)VS: } \\
\text { Tópico em } \mathrm{P}^{\prime} \text { duplicado } \\
\text { pelo clítico e Foco em } \\
\text { PF } \\
\text { (5) Ordem OVS, sem } \\
\text { retomada por clítico = } \\
\text { Foco em Pl + Prosódia }\end{array}$ & $\begin{array}{l}\text { (1) Lo único que tengo es } \\
\text { vergüenza } \\
\text { (2) le pagan de guionista en } \\
\text { Hollywood una pasta } \\
\text { (3) El piano es tocado por Juan } \\
\text { (4a) El piano lo toca Juan } \\
\text { (4b) Estuvo la miss España }\end{array}$ \\
\hline Focalizar Sujeitos & $\begin{array}{l}\text { (1) Prosódia } \\
\text { (2) Clivagem }\end{array}$ & $\begin{array}{l}\text { (1) JUAN toca el piano } \\
\text { (2) Quien toca el piano es Juan }\end{array}$ \\
\hline
\end{tabular}

Esquema 24 - Estratégias de focalização usadas em EP

${ }^{136} \mathrm{E}$ todas suas variantes. 


\section{SOBRE AS TÉTICAS E SEMI-TÉTICAS NAS DUAS LÍNGUAS}
$\checkmark$ Não dependem da ordem, mas sim do contexto e das intenções discursivas dos Falantes;
$\checkmark$ Não ocorrem somente com verbos monoargumentais (ou com propriedades Configuracionais de Predicado de um lugar;
$\checkmark$ Semi-Téticas: descrevem cenas = Orações Apresentativo-descritivas;
$\checkmark$ Formadas com verbos do tipo dicendi.

Esquema 25 - Síntese comparativa das sentenças Téticas e semi-téticas

\section{PREFERÊNCIAS ${ }^{137}$ DE ESTRATÉGIAS DE NÃO-TOPICALIZAÇÃO/ DE FORMAÇÃO DE ENUNCIADOS TÉTICOS}

\begin{tabular}{|c|c|c|c|}
\hline \multicolumn{2}{|c|}{ PB } & \multicolumn{2}{|l|}{ EP } \\
\hline Estratégia & Exemplo & Estratégia & Exemplo \\
\hline $\begin{array}{c}\text { (1) Alocar um } \\
\text { nome nu em } \mathrm{Pl}^{\mathrm{I}} \\
\text { mantendo a ordem } \\
\text { SV }\end{array}$ & $\begin{array}{l}\text { (1) Polícia } \\
\text { prende líder. }\end{array}$ & $\begin{array}{c}\text { (1) usar o verbo na } \\
\text { terceira pessoa do } \\
\text { plural, } \\
\text { indeterminando o } \\
\text { Agente e } \\
\text { mantendo a ordem } \\
\text { VO }\end{array}$ & $\begin{array}{l}\text { (1) Detienen al } \\
\text { jefe... }\end{array}$ \\
\hline & & $\begin{array}{l}\text { (2) usar Dativos de } \\
\text { afetação, com } \\
\text { ordem OVS, } \\
\text { Experienciador + } \\
\text { fenômeno } \\
\text { experimentado }\end{array}$ & $\begin{array}{c}\text { (2) No le molan } \\
\text { los perros }\end{array}$ \\
\hline
\end{tabular}

Esquema 26 - Preferências de recursos de cada língua para construir sentenças Téticas

\footnotetext{
137 Lembramos que estamos nos referindo a preferências (frequências de cada estratégia nas duas
} línguas) e não a restrições. 


\section{OUTRAS ASSIMETRIAS}

$\checkmark$ A ordem VS é muito mais usada em EP que em PB, já que essa ordem, no PB, está mais restrita aos verbos inacusativos e dicendi;

$\checkmark$ A maior incidência de Semi-Téticas no EP, com ordem (O)VS é resultante da maior flexibilidade de ordenação dos constituintes em EP que em PB e mais um indício do processo de não topicalização dos Sujeitos nessa língua;

$\checkmark$ O PB tende a manter a ordem SVO ou SV, ou seja, tende a manter os Sujeitos topicalizados em $\mathrm{P}^{\mathrm{I}}$, sejam em sentenças Categóricas ou Téticas.

Esquema 27 - Outras assimetrias entre as Téticas

Antes de encerrar esse subcapítulo, queremos destacar que, independente das estratégias usadas e das assimetrias entre as duas línguas, concluímos que a posição primordial para abrigar constituintes com função de Foco, tanto em PB como em EP, desconsiderando fatores prosódicos, é a posição absoluta de PF.

Como vimos, muitas estruturas VS que ocorreram no nosso corpus, no entanto, segundo nossa interpretação, não se configuram como Téticas, mas têm outras motivações pragmáticas, como, por exemplo, a marcação de Contraste, que é a terceira função pragmática prevista pela GDF e da qual falaremos a seguir.

\subsection{Esse eu nunca vi $x$ A ese no lo he visto nunca: a função Contraste}

\subsubsection{Noções gerais}

Em muitas abordagens teóricas, o Contraste (Contrast) é interpretado como um tipo de Foco, provavelmente porque tanto Ênfase, como Foco e Contraste envolvem saliência. Na GDF, porém, o Contraste é uma função pragmática específica, já que, tipologicamente, muitas línguas fazem uma distinção muito clara entre esses conteúdos pragmáticos (além disso, como vimos anteriormente, essa função pode coincidir com as funções de Foco e Tópico). Na GDF, portanto, o Contraste marca a intenção do Falante de diferenciar dois ou mais Conteúdos Comunicados, ou entre um Conteúdo Comunicado e informações disponíveis no contexto ou na situação discursiva, e envolve todos os tipos de Foco Contrastivo propostos por Dik (1989): 
Contrapressuposicional, Restritivo, Expansivo, Seletivo e Substitutivo. Não explicaremos cada um deles aqui, dado que, para a GDF, todos passam a receber a designação apenas de Contraste.

Em inglês, por exemplo, o constituinte em caixa alta na sentença seguinte marca o Foco (que, no inglês, é marcado por um acento prosódico - pitch- na última sílaba tônica do termo focalizado):

I like the green CAR. ${ }^{138}$

[Eu gosto do verde CARRO]

[Eu gosto do CARRO verde]

Se, no entanto, dentro do contexto, houvesse um interlocutor que dissesse que gosta do carro vermelho, o Falante de (61) acima provavelmente mudaria o acento prosódico de lugar, enunciando algo como:

\section{I like the GREEN car.}

Com essa mudança de acento, o Falante expressa seu objetivo comunicativo, que é o de contrastar sua opinião com a de seu interlocutor. Teríamos no exemplo (62), portanto, um caso de marcação de Contraste. A presença de carro vermelho no Componente Contextual é que garante a diferença entre Foco e Contraste. Esse mesmo recurso de entonação pode ser usado para marcar Contraste em PB, mas, como já explicamos, o estudo de fatores Entonacionais foge ao objetivo de nosso trabalho por enquanto.

Como dissemos acima, há línguas que marcam claramente a diferença entre Foco e Contraste, seja com sufixos, morfemas ou posições fixas no enunciado. Ainda assim, de acordo com a GDF, as três funções pragmáticas podem se sobrepor umas às outras. Desse modo, podem existir línguas em que haja uma sobreposição de Foco e Contraste; de Tópico e Contraste; de Foco e Tópico; e de Foco, Tópico e Contraste. Portanto, tanto Tópicos quanto Focos podem ser contrastados. As sentenças clivadas são exemplos de sobreposição de Foco e Contraste.

${ }^{138}$ Exemplos tomados de Hengeveld \& Mackenzie, 2008, ps. 1408. 
A sobreposição de Tópico e Contraste pode ser encontrada facilmente em coreano, por exemplo, pois essa língua dispõe de um marcador específico para essa função. Em PB, isso também é possível, quando, por exemplo, se marca prosodicamente o Tópico. A sobreposição de Tópico e Foco pode ser exemplificada pelas construções semi-Téticas, que vimos anteriormente.

Por último, pode haver a sobreposição das três funções em exemplos como (77), trazido de Hengeveld \& Mackenzie (2008, ps. 1430):

There is BEER without alcohol, not whisky.

[Há CERVEJA sem álcool, não whisky].

No exemplo (77), a combinação das funções Tópico e Foco é expressa pela escolha do tipo de construção apresentativa, enquanto a função Contraste é refletida na atribuição de acento prosódico sobre o termo beer.

Formalmente, o Contraste também pode ser expresso por meio de marcadores específicos, chamados pela tradição gramatical de Palavras denotativas, expletivos, advérbios de inclusão e de exclusão, etc. (em PB como: só, também, menos, etc. Em EP como solo, también, incluso, etc.). Essas Palavras aparecem junto com o constituinte que escopam. Assim, se escopam um constituinte com a função de Tópico, vão permanecer em PI. Da mesma maneira, se o Contraste recai sobre algum elemento que ocupa a $\mathrm{P}^{\mathrm{M}}$, é nesta posição que ele vai permanecer. É o que acontece no exemplo a seguir, em que o constituinte só escopa o constituinte que ocupa PF (na cabeça do fêmur), e que tem função de Locativo. A resposta do Interlocutor (só no fêmur) conjuga as funções de Foco (sintagmático, neste caso), por preencher a lacuna de informação do Destinatário, e Contraste, por meio do constituinte só (que restringe o lugar onde a prótese foi colocada, em contraposição a quadril inteiro):

(78) *ATA: mas ocê pôs a [/1] uma prótese só na cabeça do fêmur / aqui / ou é do quadril inteiro da <outra vez>?

*MNV: <não> // só no fêmur // (C-ORAL-BRASIL-bfamcv13).

Nas construções Téticas, o Contraste logicamente só pode aparecer em PF. Quando, ainda, o Contraste tem escopo sobre toda a Oração, vai ocupar as posições periféricas de $\mathrm{P}^{\mathrm{I}}$ ou $\mathrm{P}^{\mathrm{F}}$, obedecendo, assim, ao princípio de preservação de escopo, como no exemplo: 
(79) *TER: do lado da mãe / da Fafica / tudo pobrezim // mas é gente controladim / também // nũ é / assim / aques paupérrimo não / né // n' é gente paupérrimo não // então / $<$ tudo trabalhador> // (C-ORAL-BRASIL-bfamcv02).

No exemplo (79), o marcador também escopa toda a Oração mas é gente controladim, ocupando $\mathrm{PF}^{\mathrm{F}}$.

Tanto em PB como em EP, como comentamos rapidamente em outra seção, as estruturas clivadas constituem um dos principais recursos para a atribuição de Contraste. Por isso, embora não nos aprofundamos nesse tema, que, como já esclarecido, não integram um dos objetivos desta pesquisa, parece-nos que vale a pena fazer uma brevíssima apresentação sobre essas construções. Para isso, abrimos a seção a seguir.

\subsubsection{Breve nota sobre as sentenças clivadas (escindidas)}

Embora não haja consenso quanto ao estatuto sintático das construções clivadas na literatura linguística, o conceito de clivagem ao qual nos referimos aqui é o mesmo de Pinto (2008), considerando critérios sintáticos e semânticos, já que além da presença do verbo copulativo e da sentença relativa, as clivagens têm um caráter especificador e apresentam leituras de contraste, exclusividade e exaustividade.

Lambretch (2001, p. 401, apud PINTO, 2008a, p. 01), define a construção clivada como:

[...] uma sentença complexa contendo uma oração principal nucleada por uma cópula e uma oração relativa ou tipo relativa da qual o argumento relativizado é co-indexado ${ }^{139} \mathrm{com}$ o argumento da cópula, sendo que essas duas orações juntas expressam uma simples proposição lógica que poderia ser expressa de uma forma simples.

Ainda segundo Pinto (2008, p. 01):

[...] as sentenças clivadas são constituídas por duas orações bipartidas, cada qual com seu verbo; já as sentenças pseudo-clivadas são constituídas por uma sentença copulativa em que a relativa livre ocuparia a posição do predicado, que seleciona um sujeito, que satisfaz o valor da variável na relativa que constitui o predicado.

\footnotetext{
${ }^{139}$ A correferência (ou coindexação) é estabelecida quando o valor referencial do elemento anafórico e da expressão nominal antecedente coincidem.
} 
As estruturas dessas sentenças clivadas $^{140}$ são resultantes da dinâmica de elementos pressupostos ou novos entre os interlocutores. O conjunto de informações pressupostas e novas é estabelecido pela progressão informativa da sentença. Portanto, a única resposta possível para uma pergunta é a informação nova, pois só ela faz o discurso progredir. Simplesmente repetir a pressuposição sem acrescentar a informação nova gera uma resposta agramatical. A partir disso, pode-se entender a agramaticalidade da sentença (80c), mostrada a seguir:

\section{Quem fala?}

(80b) Quem fala é o João.

(80c) *O que o João faz é falar.

Aqui, assumimos o conceito de pressuposição de Lambrecht (2001), ou seja, aquilo que o falante assume como conhecido pelo ouvinte, e que precisa estar ativado ou "ativável" na mente do ouvinte e ser de interesse atual (no momento da enunciação). Assim, no exemplo acima, está pressuposto que alguém (x) fala. A informação nova, desconhecida pelo interlocutor, é dada pelo termo o João ( $x=$ João). Sendo assim, para que o falante B respondesse ao falante A "quem fala é o João", ele deveria supor ou imaginar que o seu interlocutor sabia ou esperava que alguém falasse naquele momento; caso contrário, uma Oração simples seria mais bemsucedida: O João fala.

Braga \& Barbosa (2009) agrupam dois tipos de estruturas, que se assemelham e também diferem entre si tanto formal como funcionalmente: as clivadas, com suas variantes (construção é que e construções que) e as pseudoclivadas, com suas respectivas variantes (pseudoclivada invertida, pseudoclivada extraposta e construção Foco-ser). As sentenças clivadas são constituídas por duas orações bipartidas, sendo que a primeira Oração é que atribui ênfase ao termo clivado e a segunda é uma Oração subordinada a essa primeira. Por outro lado, as sentenças pseudoclivadas são compostas por uma Oração copulativa em que o elemento enfatizado é o sujeito e a parte pressuposta é o predicado da miniOração. Mioto (2003) explica, da perspectiva da Gramática Gerativa, que a principal diferença entre as sentenças clivadas e as pseudoclivadas é que essas últimas se

\footnotetext{
140 Aqui, o termo clivada está sendo usado no sentido mais genérico, abrangendo todas as variantes das clivadas e das pseudoclivadas.
} 
constroem com uma expressão Wh e as clivadas, com um complementizador.

A seguir, exemplificaremos cada tipo de construção clivada, com sentenças criadas por nós e apenas em PB, pois nosso objetivo neste momento é somente mostrar as possibilidades existentes. Um pouco mais adiante, trazemos ocorrências nas duas línguas tiradas de nosso corpus.

a) Clivadas Básicas (estrutura básica: Ser + que)

(81) Tudo aqui sou eu que faço.

(82) Foi dois tombos que ele levou.

b) Construções é que:

(83) Ela é que gosta de pimenta.

c) Pseudoclivadas (estrutura básica: QU- + Ser):

(84) Naquela festa, quem se divertiu fui eu.

(85) Quem se deu bem foram os alunos. que):

(86) Produto de limpeza é o que sai mais caro.

e) Pseudoclivadas Extrapostas (estrutura básica: Ser + Quem)

(87) Foi a Mariany quem chegou.

Braga \& Barbosa (2009) defendem ainda que as construções de Foco-Ser, às quais nos referimos na seção sobre Foco, são também um tipo de clivada e que marcam Contraste. Além disso, argumentam que há diferenças relativas à distribuição de informação nessas construções, mostrando que o referente do segmento clivado nas construções que e nas clivadas tende a constituir informação [+ativada], ou seja, aquelas cujos referentes ou proposições estavam presentes na memória de curto prazo do ouvinte, no momento em que o enunciado clivado era proferido; enquanto as Pseudoclivadas apresentam taxas quase iguais para referentes [+ativados] e [ativados]. Propõem também que há variação quanto à leitura de contraste que pode ser atribuída a elas. Segundo as autoras, os contrastes explícitos são mais prováveis em construções é que; possíveis em construções que; e raras em clivadas, 
pseudoclivadas e construções Foco-Ser.

As estruturas clivadas tendem a funcionar como instrumento de organização do (sub)tópico discursivo: após a construção clivada com essa função, geralmente, se observa a mudança de subtópico, como se ilustra em (88):

I: "O que você quer?

F: O que eu quero? Eu quero continuar estudando, sabe? Se der para me formar, tudo bem, né? Se não der, eu ir arranjar uma coisa melhor para mim viver minha vida, eu sozinha, sabe? Sem ter que morar na casa dos outros. É isso que eu quero.

E: Os homens são sempre machões? (Amostra 80, fal.05, mulher)" (BRAGA; BARBOSA, 2009, p. 191).

Por outro lado, as pseudoclivadas, cujo constituinte enfatizado expressa informação [-ativada], introduzem um referente novo/inferível que é retomado como Tópico nos enunciados posteriores, como no exemplo (75) abaixo:

(89)

F.: "O Paulinho, né? Foi o mais sacrificado, os outro, a gente vai moderando o negócio, entende?

E.: É o mais velho?

F.: É o mais velho. O que MEnos apanhou foi o Marquinho. Esse que está no... o Marquinho é muito bom, ta... O Marquinho é bom demais. Marquinho é bom demais. É o filho mais novo." (Amostra 80, fal. 33, homem). (BRAGA; BARBOSA, 2009, p. 192).

O que se pode resumir pelo que foi exposto até aqui é que, de maneira geral, essas construções representam uma estratégia pragmática de enfatização de constituintes (na seção que segue se falará mais sobre a função de Ênfase). Além disso, podem funcionar como organizadoras do (sub)tópico discursivo: as clivadas, tendem a contribuir para a organização do (Sub)tópico e as pseudoclivadas tendem a introduzir Tópico no discurso.

Pinto (2008) faz diversos estudos comparando as estruturas clivadas em diferentes variedades da língua espanhola (europeia, cubana, mexicana e argentina, além de comparar esses dados com os usos em português, francês e italiano). Segundo o autor, cada variedade do espanhol apresenta dados que diferem tanto quantitativa como qualitativamente em relação às construções clivadas. O espanhol europeu, por exemplo, apresenta menos variedades de estruturas clivadas que o espanhol americano, ao menos nos dados por ele analisados: enquanto o europeu apresenta apenas estruturas pseudoclivadas, as variedades do espanhol americano 
analisadas por ele, que além das pseudoclivadas, também apresentam as verdadeiras clivadas.

Vejamos algumas dessas ocorrências em nosso corpus:

Exemplos de clivadas em PB:

(90) *MAR: <isso aqui / digamos / é uma> segunda camada / também / né // ${ }^{*} F A B:<$ hum hum $>/ /$ - bpubdl09).

*MAR: <porque / a primeira> coisa que ele fez foi a peça / né // (C-ORAL-BRASIL

(91) *LUC: nũ é isso // foi na quinta série que cê começou a estudar inglês // *MAR: foi // (C-ORAL-BRASIL-bpubdl11).

(92) *VER: hum hum //

*GIL: / fantástico //

*VER: é isso que eu pensei // (C-ORAL-BRASIL-bfamcv12).

O esquema de representação das posições de (92) é o seguinte:

\begin{tabular}{|c|c|c|}
\hline $\mathbf{P}^{\mathbf{I}}$ & $\mathbf{P}^{\mathbf{l + 1}}$ & $\mathbf{P}^{\mathbf{M}}$ \\
TOP/CONT & TOP & \\
\hline é isso que & eu & pensei \\
\hline
\end{tabular}

Alguns exemplos de escendidas em EP são os seguintes:

(93) ELE: $[<]<$ sabes ?\$ prefería / que si> él lo sentía así / que lo dejara //\$ porque al final / lo que yo no quiero / es hacerle daño / tía //\$ y al final / esta historia / al final va a acabar mal / <obviamente> //\$ (C-ORAL-ROM-efamcv10)

[o que eu não quero é causar-lhe dano]

(94) $\quad{ }^{*} E L E:[<]<c l a r o>/ / \$$ es que yo lo que quería era eso $/ / \$$ dejaros un casete $\ldots \$$ sabes ?\$ tenía por ejemplo / cintas para el / (C-ORAL-ROM-efamdI08)

[é que eu o que queria era isso]

(95) *NIE: $[<]<$ no //\$ en cualquier> caso / lo que hay que hacer es / la pared para acá //\$ pero no traerla hacia acá $/ / \$$ eso es \&otr [/] era otra cosa $/ / \$<e s$ que hay dos posibilidades> //\$ (C-ORAL-ROM-efamdl19)

[o que tem fazer é a parede pra cá] 
Esclarecidas essas noções gerais sobre essa função, vamos ao cerne de nossa questão, que é saber qual a relação entre a ordem de constituintes Configuracionais e a atribuição de Contraste.

\subsubsection{Ordem dos constituintes para a atribuição de Contraste}

Hengeveld \& Mackenzie (2018) apresentam um exemplo do português europeu (e que pode ser estendido perfeitamente ao PB), a fim de mostrar como a flexibilidade sintática dessa língua pode funcionar como um recurso para diferenciar Foco de Contraste, considerando que em ambas as sentenças, a entonação seja ascendente:

\section{Eu prefiro que ela venha.}

Eu prefiro que venha ela. (HENGEVELD \& MACKENZIE, 2008, ps. 5272).

Em (96), os autores atribuem a função de Foco ao constituinte venha. Já em (97), atribuem a função Contraste a ela. Vale observar que em (96) não se estão levando em consideração as diferentes possibilidades de marcação de Contraste por meio da marcação prosódica em cada um dos constituintes. Considera-se, aqui, para fins de exemplo, apenas a ordenação dos constituintes, tendo ambas as sentenças a mesma entonação.

Tanto em PB como em EP, constatamos que um dos principais recursos para marcação de Contraste por meio da ordenação dos constituintes é alocar em $\mathrm{P}^{\prime}$ um constituinte que normalmente ocuparia domínio à direita de $\mathrm{PM}^{\mathrm{M}}$ (gerando ordenações OSV, OVS ou OV). A seguir, trazemos algumas análises de ocorrências em PB.

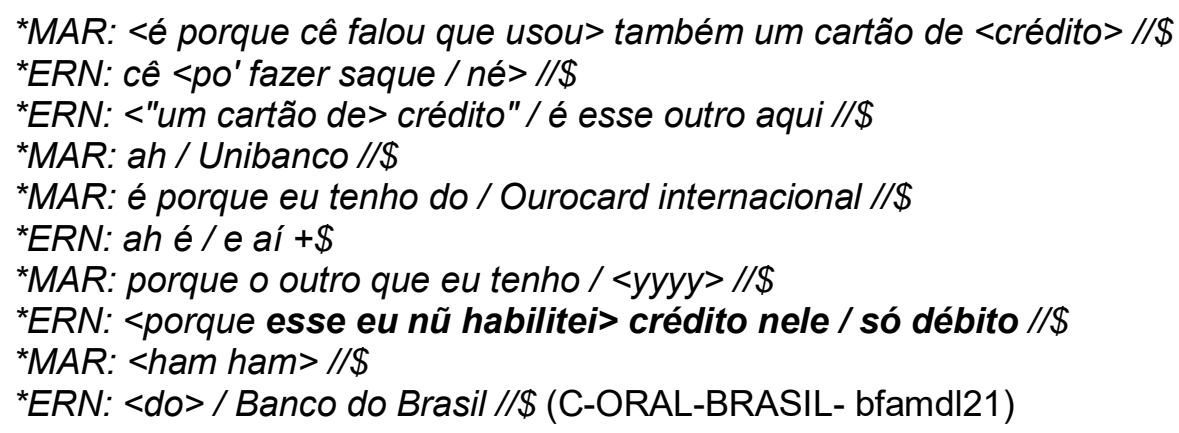


Em (98), a palavra esse, com função sintática de Objeto (e que, portanto, viria normalmente depois do verbo habilitar em uma sentença como eu não habilitei esse), funciona como Tópico e retoma cartão de crédito. No entanto, como há dois tipos de cartões no contexto (de crédito e débito e do Unibanco e do Banco do Brasil), o Falante prefere alocar esse constituinte em $\mathrm{P}^{\mathrm{I}}$, justamente para diferenciá-los e atribuir ao cartão tema da predicação a função de Contraste (que, portanto, coincide com o Tópico). O Contraste também se dá pelo marcador de restrição só, na segunda parte do enunciado.

O contexto do seguinte exemplo é o seguinte: dois homens, um tatuador e um cliente a ser tatuado, estão conversando sobre os desenhos de Escher (artista gráfico holandês). Ambos conhecem as obras do artista, mas, quando um dos Falantes se refere a um quadro em especial, o outro responde que esse ele nunca havia visto. Por essa razão, aloca o constituinte esse, outra vez com função de Tópico em $\mathrm{P}^{\prime}$ e sobrepõe-lhe função de Contraste, indicando que conhece os outros quadros, mas não esse. Notemos, também, que a função de Contraste é alcançada por meio da repetição dos constituintes de negação nos dois casos: primeiro, pelo uso concomitante de não e nunca; e, depois, pela repetição de não.

*MAR: <é tipo aqueles dos pássaros que > +

${ }^{*} F A B:<0$ [/1] um anjo daqui e o daqui> forma o [/1] o morcego <dali e vai indo> //

*MAR: <tipo uma plantação> que vai virando os pássaros //

${ }^{*} F A B$ : esse eu nunca vi não / é dele também?//

*MAR: é //

${ }^{*} F A B$ : <esse aí nũ vi não> // (C-ORAL-BRASIL-bpubdl09)

Podemos perceber a diferença de intencionalidade entre essa ordenação e a ordenação icônica eu nunca vi esse. Nessa segunda opção, provavelmente a intenção do Falante seria apenas a de declarar algo, sem contrastar nenhuma informação. Algo semelhante ocorre em (100), apesar de ser uma Oração composta/subordinada e que, por isso, não entrará diretamente em nossa análise:

(100) *LUC: aquele dia que a gente comentou lá no / eu tava em sala / cê comentou comigo a diferença de inglês pra espanhol // como é que é essa diferença // cê acha que // *MAR: ah / aque' negócio lá // \&he / por causa que / ah / espanhol / se ocê já [/2] cê for lá na Espanha lá / cê já sabe comunicar / cê entende um pouco as coisa que o [/2] que o pessoal fala lá / né //

*LUC: hum hum // 
*MAR: aí inglês não // inglês cê tem que pegar mais sério / porque / é poucas palavras que / têm semelhança com o português / né //

*LUC: então cê acha que cê tem que + \&he / que que cê [/3] que que cê chama de "pegar mais sério" //

*MAR: estudar / mais //

*LUC: hum hum // (C-ORAL-BRASIL-bpubdl11)

Em (100), temos uma nítida comparação entre as línguas inglesa e espanhola: segundo o Falante, o inglês é mais difícil e, como esse é o constituinte contrastado, é posicionado em $\mathrm{P}^{\mathrm{I}}$, ao invés, outra vez, de se manter no domínio de $\mathrm{PM}^{\mathrm{M}}$.

No exemplo (101), temos uma Ilocução Interrogativa. Os participantes estão em um hospital: um deles foi operado e o outro é a visita. Apesar de tratarmos desse tipo de llocução no capítulo 6, é pertinente antecipar aqui uma hipótese que temos: o Falante faz uma pergunta somente para confirmar a informação que ele julga ser verdadeira, a qual chamaremos de Foco Pressuposto, já que indica a informação nova mais relevante (e esperada), mas que ainda precisa ser confirmada (no nosso exemplo expressa pelo constituinte fratura exposta). Por isso, ele coloca esse constituinte em $\mathrm{P}^{\mathrm{I}}$ e reforça essa pressuposição pelo constituinte né, em Pre. Aqui, portanto, acreditamos haver uma sobreposição das funções de Foco e Contraste (já que o que se quer destacar é que o motivo da operação do Interlocutor foi uma fatura exposta e não outro qualquer:

*ATA: fratura exposta /cê operou, né?

* JON: operei (C-ORAL-BRASIL-bfamcv13)

Se o Falante não achasse que fratura exposta fosse o motivo da operação, em contraste com todas as outras possibilidades de causas para uma operação, provavelmente escolheria dizer: O que você operou? Nesse caso, se esperaria uma resposta tanto positiva quanto negativa (o grau de pressuposição de uma resposta positiva, portanto, seria menor que a expressa pela mudança de ordenação).

Gostaríamos de comentar um último exemplo em PB:

(102) *TER: escuta // do + não // lado des também nũ é rico não // mas é controlado // igual o nosso // a + do lado [/2] hhh do lado + o Zé Carlos vai dar a televisão // o outro tio do Anderson vai dar a máquina de lavar // Brastemp // o outro vai dar [/2] vai dar / <microondas> //

*RUT: <geladeira> //

*JAE: não / <geladeira a Fafica // já deu> // (C-ORAL-BRASIL-bfamcv02). 
Em (102), as participantes estão conversando sobre os presentes de casamento que a filha de uma delas vai ganhar. A Falante identificada pela sigla TER conta de vários itens que já foram prometidos por diferentes convidados para a cerimônia. Então, a Falante RUT pergunta sobre quem vai dar a geladeira e a Falante JAE responde que a geladeira já foi dada pela Fafica. Entendemos que no trecho analisado, temos três Atos Discursivos (A): o primeiro é constituído apenas por não, para indicar que a geladeira não será dada (não é uma ação futura, como no caso dos demais presentes), mas sim algo que já aconteceu. O segundo A é constituído por geladeira a Fafica. Aqui, entendemos que o a antecipação do constituinte geladeira assemelha-se ao recurso de uma estrutura clivada: a geladeira foi a Fafica (que deu). Por fim, o terceiro A é um Esclarecimento (uma das funções retóricas que explicaremos ao final deste capítulo) e que vem em Pre, fora da Oração (isso só pode ser constatado por meio da pausa que a Falante faz antes de enunciar esse Ato), funcionando como uma espécie de aliás: Geladeira quem vai dar é a Fafica. Aliás, já deu. Em conclusão, temos uma ordenação OS/V, em que o Objeto é colocado antes do Sujeito para marcar Tópico e Contraste (em comparação com os demais presentes). Notemos como a prosódia e as pausas são essenciais para a interpretação dessa ocorrência, já que, em outra configuração prosódica, poderíamos ter uma pausa depois de geladeira, atribuindo a esse constituinte a função de Orientação (que será o tema da próxima seção).

Todos os demais exemplos que obtivemos em PB nos levaram a concluir, ao menos com base em nosso corpus, que a ordenação usada para a marcação de Contraste é a OSV e em todas, com exceção da (102), que, como explicamos, é um caso especial, em que o verbo na verdade ocupa Pos, essa ordenação funciona para contrastar Objetos (e não Sujeitos, que, como vimos é focalizado e/ou contrastado em PB por meio ou da prosódia ou de estruturas clivadas). Esse é um dado muito relevante na comparação com os dados em EP, em que não obtivemos nenhuma ocorrência com essa ordenação, como mostramos nos exemplos a seguir.

(103) *PAZ: claro //\$ pero bueno //\$ yo no sé quién ganará la liga / este año / <tía $>/ / \$$

${ }^{*} P I E:[<]<$ bueno $>$ pues el Madrid / Mari //\$

${ }^{*} P A Z$ : pero / <\&hombr $>+\$$

${ }^{*} P I E:[<]<$ conforme $>$ va el Madrid / <de adelantado $>$...\$

*PAZ: [<] <no ihombre!\$ // si> hoy gana el Madrid / tía / es muy <probable> //\$

${ }^{*} P I E:[<]<y$ si> no gana / también / si le lleva nueve puntos al Barça //\$ (C-ORALROM-efamdl33) 
[hoje ganha o Madrid]

[Hoje é o Madrid que ganha]

Em (103), se contrasta o time Madrid com o time rival, com quem ele jogará e o Falante pretende expressar que o Madrid é que vai ganhar, e não o outro time. Para marcar esse contraste, coloca-se o constituinte el Madrid, Sujeito Tópico, em PF, refletindo uma ordenação VS.

No exemplo abaixo, ocorre algo semelhante, ou seja, posiciona-se o Sujeito Tópico (Aitana e yo) em $\mathrm{PF}^{\mathrm{F}}$ das orações para marcar Contraste: no primeiro caso, o Contraste corresponderia ao que Dik (1997) chama de Foco restritivo, já que somente a Aitana (vejamos a relevância do constituinte sólo para marcar essa restrição) é quem pode abaixar as patas do cachorro que viaja no carro com os participantes (ela e mais ninguém). No segundo caso, de todas as pessoas que poderiam ir sentadas ao lado do cachorro, cabe justamente à Falante esse "castigo" (expresso inclusive pela repetição da sentença me siento yo a su lado): o constituinte yo em $\mathrm{PF}^{\mathrm{F}}$, portanto, marca Contraste entre yo e as demais pessoas que viajam no carro.

(104) *ELE: $[<]<$ un perro grandote> / no?\$ entonces / para sentarle atrás / hay que bajarle las patas $/ / \$$ entonces / sólo lo puede hacer Aitana $/ / \$$ porque no se va a \&de $+\$$ sabes ?\$ por \&a [/] por mí / no se va a dejar / que le tire de las patas / y le ponga donde yo quiera //\$ entonces / le / dijimos a Ana / déjalo / tranquilo / y él se sienta //\$ lo pone Aitana / y luego ya déjalo //\$ sí / sí //\$ pero me siento yo a su lado //\$ me siento yo a su <lado> //\$ (C-ORALROM-efamdl08)

[só o pode fazer Aitana] / [me sento eu ao seu lado]

[só a Aitana pode fazer isso] / [sento eu ao lado dele]

O exemplo (105) marca claramente uma comparação entre o Falante e as demais pessoas (somente ela é quem o ajuda, enquanto os outros não ajudam em nada). Para isso, aloca-se o constituinte yo à direita de $\mathrm{PM}^{\mathrm{M}}$ (em mais uma ordenação OVS): ${ }^{141}$

*NAT: $[<]<y$ qué lo pintáis> ?\$ entre Miguel y tú ?\$

*PRI: Miguel es el que pinta //\$ nosotros le ayudamos //\$ bueno / le ayudamos / éstas no ayudan nada $/ / \$$

141 Para nossa análise, estamos considerando apenas a primeira ocorrência, pois a segunda é uma estrutura clivada, que, apesar de marcar Contraste, como já explicamos, foge ao escopo de nossa pesquisa. 
${ }^{*} P R I:[<]<$ le ayudo yo $>/ / \$$ porque se pone de enfadado / que luego empieza / que todo lo tengo yo que hacer solo $/ / \$$ que todo lo tengo yo que hacer solo $/ / \$$ que nadie me ayuda //\$ (C-ORAL-ROM-epubdl06)

[Ihe ajudo eu] / [tudo o tenho eu que fazer que fazer sozinho]

[eu é que/quem ajudo ele/ quem ajuda ele sou eu] / [eu é que/quem tenho que fazer tudo sozinho/ quem tem que fazer tudo sozinho sou eu]

Vejamos o exemplo (106), já citado em outro momento, mas aqui resgatado para mostrar algumas outras questões:

(106) *MAR: ella sigue estando ahi //\$ y luego operaron a mi madre / y estaba exactamente lo mismo //\$ y a mi padre le han operado también / y sigue exactamente lo mismo //\$ (CORAL-ROM-efamcv02)

[ $\varnothing$ meu pai o operaram também]

[(o) meu pai eles operaram também]

Aqui, o Falante escolhe colocar o constituinte a mi padre na $\mathrm{Pl}^{\mathrm{I}}$ para marcar a função de Contraste, já que, anteriormente, o Falante diz que sua mãe foi operada: "[...] luego operaron a mi madre [...]" [a seguir operaram a minha mãe]. Note-se que, nesse primeiro Ato Discursivo, o Falante opta por manter a ordem icônica dos constituintes, mantendo o Objeto em domínio de $\mathrm{PM}$, pois não há intenção de marcar nenhuma função comunicativa especial, pois deseja-se apenas dar uma informação. Por outro lado, quando o Falante quer comparar e contrastar essa informação com a seguinte (a operação do pai), ele opta por colocar o constituinte que carrega o Contraste (a mi padre) em $\mathrm{P}^{\mathrm{I}}$. Aqui, temos uma ordem OV (com O duplicado e Sujeito indeterminado pela desinência de terceira pessoa do plural do verbo).

No exemplo (107) temos o relato de uma situação em que vários amigos estavam dormindo em um mesmo local e um deles colocou o despertador. No entanto, eles discutem para ver quem teria que se levantar primeiro. Assim, usa-se os verbos no imperativo (ve levantándote e levántate) reforçados pelo uso dos pronomes com função de Sujeitos (tú). O uso desses pronomes é claramente contrastivo, uma vez que as desinências dos verbos, acrescidas dos pronomes oblíquos (te) já são mais que suficientes para evitar ambiguidades. A intenção da Falante, ao alocar tú em $\mathrm{P}^{\mathrm{F}}$, é de mostrar que a outra pessoa é que tem que se levantar, e não ela. Quando, ao perceber que isso não será possível, ela fica nervosa (o que se expressa pela expressão ijoder! [foder/caramba] que antecede o próximo Ato Discursivo, em que agora yo é que aparece em $\mathrm{P}^{\mathrm{F}}$ (ao invés do tú de antes). 
(107) *PAT: hhh y el otro / hhh / como Benito / y yo $+\$$ pues [/] pues nos pusimos en mi móvil de / despertador / no ?\$ y empieza Jose / venga / que +\$ digo / ijoder! / ve levantándote tú //\$ vete al baño $/ / \$$ no / levántate tú $/ / \$$ digo / será posible //\$ digo Dani / digo venga / ya te puedes levantar //\$ hhh / y el tío ahí //\$ digo ijoder! / me tendré que levantar yo //\$ y ya \&empeza $+\$$ a las nueve $/ / \$$ a las nueve y media nos levantamos al final $/ / \$$ fuimos a $[/]$ a desayunar donde la abuela / a despedirnos y eso / y ya nos vinimos $/ / \$$ pero bueno $/ / \$$ no sé //\$ nos cundió bastante / la verdad //\$ porque / hhh / para ir un día y medio / vimos a todo el mundo //\$ a todo el mundo vimos //\$ (C-ORAL-ROM-efamcv05)

[vai se levantando você] / [levanta você] / [me terei que levantar eu]

[idem] / [idem]/ [eu é que terei que (me) levantar]

O último exemplo que queremos comentar nessa seção é o (108):

(108) *PIE: a mí / es que no [///] me pone muy nerviosa estos partidos //\$

*PAZ: $h$ hh //\$

*PIE: yo no digo que a lo mejor / lo pongo / lo quito / pero / que no / no me gusta //\$

${ }^{*} P A Z$ : verlo //\$

*PIE: el Madrid Barça no me gusta //\$ (C-ORAL-ROM-efamdl33)

[(Eu) não gosto do Madrid Barça]

Quisemos trazer esse exemplo aqui para compará-lo com os (71), (72) e (73), dos quais falamos sobre os eventos de experiência. Nesses exemplos, havíamos indicado que parece haver uma tendência a manter a ordem experienciador+evento experienciado para as sentenças Téticas, nas quais o que se quer enfatizar é o evento em si. Em (108), no entanto, temos um caso (o único do nosso corpus) em que aparece a ordem evento experienciado+experienciador. Acreditamos que essa ordenação seja justamente para marcar Contraste no constituinte que indica o evento experienciado: no nosso exemplo, é do Madrid Barça que o falante não gosta, mas de outros times, sim.

Considerando todos os exemplos de EsCos dinâmicos (o que exclui o último exemplo, que trazemos a modo de curiosidade, mas que não integra nossos objetivos de pesquisa) e as sentenças clivadas ou subordinadas, chegamos à seguinte constatação: ao menos em nosso corpus, as ordenações mais frequentes de constituintes Configuracionais para marcar Contraste em EP foi OVS e VS. Houve 3 ocorrências de VS em (103) e (107 - 2 ocorrências), que eram compostas por verbos monoargumentais (de Propriedade Configuracional de um lugar: ganar e levantarse), sendo que o levantarse está em sua forma imperativa, o que dispensaria o pronome. 
Portanto, em EP, não é exatamente a posição em que o pronome Sujeito aparece, mas sim a sua própria presença que indica o Contraste (e isso também ocorre em PB, como veremos no quadro abaixo). Foram 3 ocorrências da ordem OVS em (104 - 2 ocorrências) e (105), sendo as 3 com Objetos em forma de clítico (lo, me, le). Todas essas ocorrências funcionaram para contrastar os Sujeitos Tópicos, alocando-os em PF. A única ordenação OV foi a (106): diferentemente das demais ocorrências, aqui a intenção era contrastar o Objeto e, por isso, não se usou apenas uma forma clítica, mas sim uma forma lexical (a mi padre) duplicada por um clítico (le) e preferindo indeterminar o Sujeito (já que não era o Tópico da Oração).

O fato interessante que os dados nos mostraram é que, inversamente ao PB, que só apresentou ordens OSV, em EP não obtivemos nenhuma ordenação desse tipo para marcar Contraste. Claro que são poucas ocorrências e de apenas uma variedade da língua espanhola, o que nos impede de fazer qualquer tipo de generalização sem o risco de cometermos incoerências. No entanto, essa rápida análise pode indiciar uma tendência nessas línguas, que merece ser melhor investigada.

No quadro a seguir, assim como fizemos com as funções anteriores, trazemos uma proposta de tradução funcional (ou seja, pensada para manter a intencionalidade expressa na língua fonte), tanto dos enunciados em PB para o EP, como o contrário. Lembramos que esse exercício se justifica apenas para nos ajudar a visualizar de forma mais clara as possibilidades e preferências de recursos para marcação de Contraste em ambas as línguas, sempre a partir dos dados que encontramos em nosso corpus, sem pretensões de generalizações, já que em outros contextos os Falantes poderiam recorrer a outras estratégias. A parte em azul do quadro refere-se às traduções do PB para o EP, e as em amarelo, às do EP para o PB. A sigla Cliv. refere-se às sentenças clivadas, $(S)$ refere-se à Sujeito Indeterminado ou omitido e $O^{2}$ indica Objeto duplicado: 


\begin{tabular}{|c|c|c|c|c|}
\hline $\begin{array}{c}\text { Fragmento } \\
\text { original }\end{array}$ & $\begin{array}{l}\text { Ordenação } \\
\text { do original }\end{array}$ & $\begin{array}{l}\text { Proposta de } \\
\text { tradução }\end{array}$ & $\begin{array}{c}\text { Ordenação } \\
\text { da } \\
\text { tradução }\end{array}$ & $\begin{array}{c}\text { Elemento } \\
\text { Contrastado }\end{array}$ \\
\hline $\begin{array}{l}\text { esse eu não } \\
\text { habilitei crédito } \\
\text { nele, só débito }\end{array}$ & OSV & $\begin{array}{c}\text { Ese no lo he } \\
\text { habilitado (para) } \\
\text { crédito, sólo } \\
\text { débito. }\end{array}$ & $\mathrm{O}^{2}(\mathrm{~S}) \mathrm{V}$ & Objeto Tópico \\
\hline $\begin{array}{c}\text { esse eu nunca vi } \\
\text { não }\end{array}$ & OSV & $\begin{array}{c}\text { ese no lo he visto } \\
\text { nunca }\end{array}$ & $\mathrm{O}^{2}(\mathrm{~S}) \mathrm{V}$ & Objeto Tópico \\
\hline $\begin{array}{c}\text { Fratura exposta } \\
\text { você operou, né? }\end{array}$ & OSV & $\begin{array}{l}\text { fractura expuesta } \\
\text { operaste, ¿sí? }\end{array}$ & $\mathrm{O}(\mathrm{S}) \mathrm{V}$ & Objeto Foco \\
\hline hoy gana el Madrid & VS & $\begin{array}{c}\text { Hoje ganha o } \\
\text { Madrid/ Hoje é o } \\
\text { Madrid que ganha }\end{array}$ & VS / Cliv. & Sujeito Tópico \\
\hline $\begin{array}{c}\text { solo lo puede hacer } \\
\text { Aitana }\end{array}$ & OVS & $\begin{array}{c}\text { Só a Aitana (é } \\
\text { que/quem) pode } \\
\text { fazer isso / Isso só } \\
\text { a Aitana (que) } \\
\text { pode fazer }\end{array}$ & $\begin{array}{l}\text { SVO / } \\
\text { OSV }^{142 / /} \\
\text { Cliv. }\end{array}$ & Sujeito Tópico \\
\hline $\begin{array}{c}\text { me siento yo a su } \\
\text { lado }\end{array}$ & $V^{143}$ & $\begin{array}{c}\text { sento eu ao seu } \\
\text { lado }\end{array}$ & VS & Sujeito Tópico \\
\hline le ayudo yo & OVS & $\begin{array}{c}\text { Eu é que/quem o } \\
\text { ajudo/ } \\
\text { Quem o ajuda sou } \\
\text { eu }\end{array}$ & Cliv. & Sujeito Tópico \\
\hline $\begin{array}{l}\text { a mi padre le han } \\
\text { operado también }\end{array}$ & $\mathrm{O}^{2}(\mathrm{~S}) \mathrm{V}$ & $\begin{array}{c}\text { o meu pai eles } \\
\text { operaram também }\end{array}$ & OSV & Objeto Tópico \\
\hline levántate tú & VS & levanta você & VS & Sujeito Tópico \\
\hline
\end{tabular}

142 As ordenações SVO e OVS, neste caso, só são possíveis devido ao uso concomitante do operador só. Como dissemos anteriormente, trata-se de um caso de Contraste restritivo. Haveria de se investigar se, em PB essas ordenações são especificamente para este tipo de Contraste, já que, para os Contrastes não restritivos, o que vimos foi o uso de uma estrutura clivada. Cremos, aqui, que se trate mais de um caso de Contraste ocasionado pelo uso de um operador, mais que pela ordem de palavras. $143 \mathrm{O}$ verbo sentarse, em E, é reflexivo/pronominal, assim também como pode ser em PB: sentar-se. No entanto, acreditamos que se a ordem fosse mantendo o sujeito em posição inicial, sem a marcação de contraste, teríamos: eu (me) sento. Para a marcação de contraste, o pronome oblíquo parece ser inviável: *me sento eu. Suspeitamos que haja alguma relação entre os pronomes oblíquos em EP como mais uma estratégia para evitar Sujeitos Tópicos. Essa suspeita está baseada em estruturas muito típicas dessa língua como Se me olvidó el libro, ao invés de (Yo) olvidé el libro, marcando involuntariedade no primeiro caso ou como em Me hice la comida, ao invés de (Yo) hice la comida (para mí), e tantos outros exemplos. Em PB o recurso do clítico no lugar do Sujeito Tópico é muito menos usual e, muitas vezes, agramatical em determinados contextos. Cremos que esse tema valeria uma pesquisa mais aprofundada. 
Tentamos sintetizar as análises do quadro acima da seguinte maneira (sendo que 1, 2 e 3 lugares se referem às Propriedades Configuracionais de predicação):

\begin{tabular}{|c|c|c|}
\hline Elemento contrastado & PB & EP \\
\hline Objeto Tópico & OSV & $\mathrm{O}^{2}(\mathrm{~S}) \mathrm{V}$ \\
\hline Objeto Foco & OSV & $\mathrm{O}(\mathrm{S}) \mathrm{V}$ \\
\hline \multirow{2}{*}{ Sujeito Tópico } & $\begin{array}{c}1 \text { lugar = VS } \\
\text { /Cliv. }\end{array}$ & VS \\
\hline & $\begin{array}{c}2 \text { ou } 3 \text { lugares } \\
=\text { OVS } \text { SVO }^{144} / \\
\text { Cliv }\end{array}$ & OVS \\
\hline
\end{tabular}

Esquema 28 - Ordenações de constituintes contrastados

É importante ressaltar que, em muitos casos, para a marcação das funções de Foco e de Contraste, é possível usar estruturas clivadas nas duas línguas, embora, como já apontamos anteriormente, elas não ocorram de maneira idêntica nem no PB em comparação com EP e nem na comparação de diferentes variantes do EP. Como, porém, essas sentenças não são tema de estudo neste trabalho, apenas as citamos quando uma estrutura da língua $A$ (seja o EP ou o PB) provavelmente seria expressa na língua $B$ valendo-se justamente de uma sentença clivada. Isso não significa que uma sentença clivada na língua A não possa ser expressa por uma clivada na língua B. Assim, por exemplo, ao invés de o Falante recorrer à estratégia de ordenação dos constituintes para marcar o Contraste em uma sentença como le ayudo yo, que traduzimos por Eu é que/quem o ajudo ou por Quem o ajuda sou, ele poderia ter optado por usar uma clivada em EP também, em algo como Quien le ayuda soy yo ou Yo soy quien le ayuda ou Soy yo el que le ayuda.

Há, ainda, uma estratégia extremamente produtiva em EP para a marcação de Contraste, da qual falaremos na seção a seguir.

\footnotetext{
144 Deixamos a sigla Cliv. em negrito para indicar que há uma suspeita de que essa seja a estratégia
} preferida em PB quando não se trata de Contraste restritivo. 


\subsubsection{Sujeitos plenos $x$ Sujeitos nulos na marcação de Contraste}

Conforme vimos no capítulo Zero, estudos como os de González (1994), Groppi (2006) e Freire Santos (2013) demonstraram que há uma forte tendência de omissão dos Sujeitos pronominais em Espanhol, que, à primeira vista e como já se disse em várias ocasiões, deve-se à preservação das desinências verbais nessa língua. No entanto, apesar da riqueza morfológica dos verbos em E e da aparente redundância que causaria a expressão dos pronomes Sujeitos, Fanjul (2014), assim como Fernández Soriano (1999) e as pesquisadoras citadas acima, observam que sua expressão não é um fator estilístico, mas que "[...] está relacionado à progressão da informação, com consequências na interpretação, especificamente na identificação da referência". (FANJUL, 2014, p. 35). Assim, a sua realização revela intenções comunicativas que ultrapassam questões de estilo e opcionalidade. Segundo González (1994, p. 97):

A escolha entre uma forma pronominal plena e uma forma pronominal nula para o argumento sujeito é, sem dúvida, uma questão extremamente complexa, pelos inúmeros fatores, das mais diversas ordens, que ela envolve, entre elas uma suposta opcionalidade. Se é verdade que espanhol e português são línguas às quais se aplica o parâmetro do sujeito nulo, também é verdade que as formas de aplicálo envolvem diferenças consideráveis que é preciso explicitar.

O que apresentamos neste subcapítulo (e também em outras partes de nossa tese, quando falamos, entre outros temas, do Parâmetro do Objeto Nulo) confirma um estudo feito por Fanjul (2014) ao analisar um trecho do romance de Clarice Lispector, Uma aprendizagem ou o livro dos prazeres, e de sua tradução para o E por Cristina Sáenz de Tejada e Juan García Gayo. Fanjul (2014) constatou que há um número muito maior de pronomes Sujeitos na versão em PB que na em E, além de que os pronomes eu e tu desaparecem e os de terceira pessoa (ele, ela) só se mantêm na tradução com função desambiguadora, já que a forma verbal desses casos pode referir-se a pessoas diferentes. $O$ pesquisador também constatou que algo inverso acontecia com os pronomes com função de complemento verbal (de Objetos): a tradução do trecho em $\mathrm{E}$ apresentou muitíssimos mais pronomes oblíquos (clíticos) que o original em $\mathrm{PB}$, onde ou aparecem vazios ou expressos por pronomes fortes (do caso reto). 
Enríquez (1984, apud GONZÁLEZ, 1994) constata que o uso de Sujeitos pronominais aumenta com verbos de apreciação, valorização e opinião. Também são mais frequentes em orações simples (não regidas), em construções comparativas e em contextos e que há dois ou mais participantes (como em diálogos e conversas, por exemplo). De todos os fatores analisados, o ponto em comum entre todos é a ideia de contraposição, ou seja, de contraste. Segundo González (1994), é esse o traço que efetivamente parece determinar os usos de Sujeitos pronominais ou nulos em $\mathrm{E}$.

A presença de constituintes com função sintática de Sujeitos, expressos em formas de pronomes (principalmente yo, tú e nosotros), no nosso corpus, confirmou esse caráter altamente contrastivo para esses constituintes. Os dados que obtivemos, portanto, corroboram com os estudos já realizados. O gráfico seguinte mostra a predominância do Sujeito nulo no Espanhol, em detrimento do pronominal (aqui, não estamos considerando os Sujeitos lexicais, como nomes próprios, por exemplo):

\section{Sujeitos pronominais $x$ Sujeitos nulos em EP}

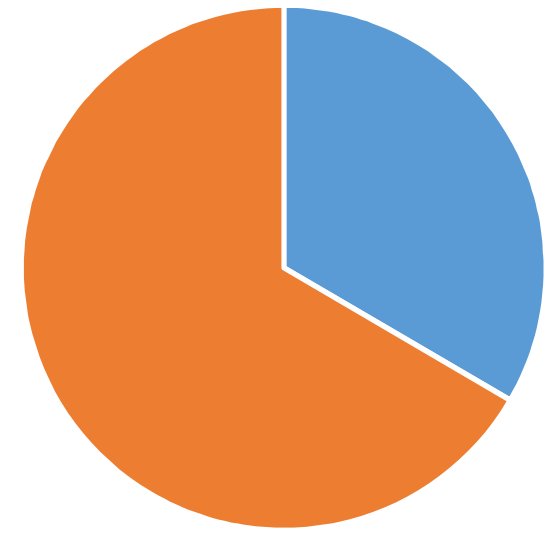

- Pronominais (383) - Nulos (763)

Gráfico 4 - Sujeitos pronominais $x$ Sujeitos nulos em EP

Assim, quando o Falante usa um Sujeito pronominal explícito, principalmente as formas de primeira e segunda pessoas, muito provavelmente sua intenção é contrastar esse Sujeito com algum outro. Os pronomes de terceira pessoa (él, ella), no entanto, geralmente são usados apenas para marcar referencialidade e evitar ambiguidades, já que a desinência verbal de terceira pessoa não tem um referente 
único (um verbo como canta, por exemplo, pode se referir a él, a ella ou até mesmo à segunda pessoa formal, usted). Como o nosso corpus é constituído por diálogos e conversas, o pronome que mais ocorreu foi o yo (e atribuímos esse dado à característica egocêntrica da linguagem, bem como ao destaque que se quer dar às ações desse eu em contraposição às ações dos interlocutores: tú, usted).

Sobre o egocentrismo da linguagem, nos baseamos em Benveniste (1989) e Toldo \& Valério (2016), ao dizerem que o discurso somente se instaura no momento em que o Falante emprega o pronome eu para referir-se a si próprio, sempre em oposição a tu e a ele/ela. Segundo o autor, essa instauração do Sujeito na linguagem (e aqui, o termo Sujeito não se refere à Sintaxe, mas sim ao Discurso), através da categoria de pessoa, é a condição mesma do discurso. De acordo com Toldo \& Valério (2016):

O fato de eu designar a cada vez uma pessoa - aquela que dele se apropria - concretiza a realização de uma experiência humana, a qual se instaura a cada vez que alguém enuncia e que revela o instrumento linguístico que a funda. Essa atualização da experiência na linguagem é algo essencial que jamais poderá faltar a uma língua, é a possibilidade mesma do discurso. Uma dialética singular é a mola desta subjetividade teoriza Benveniste e explica: é que os pronomes pessoais configuram-se, fora do discurso, em formas vazias, que somente são preenchidas a partir do instante em que alguém deles se apropria pelo ato de linguagem (TOLDO \& VALÉRIO, 2016, p. 32).

O gráfico seguinte representa os tipos de pronomes funcionando como Sujeitos pronominais explícitos que apareceram em nosso corpus do EP. A alta incidência do uso de yo, seguida (embora com número muito menor) pelo uso de tú comprova o que falávamos acima: 


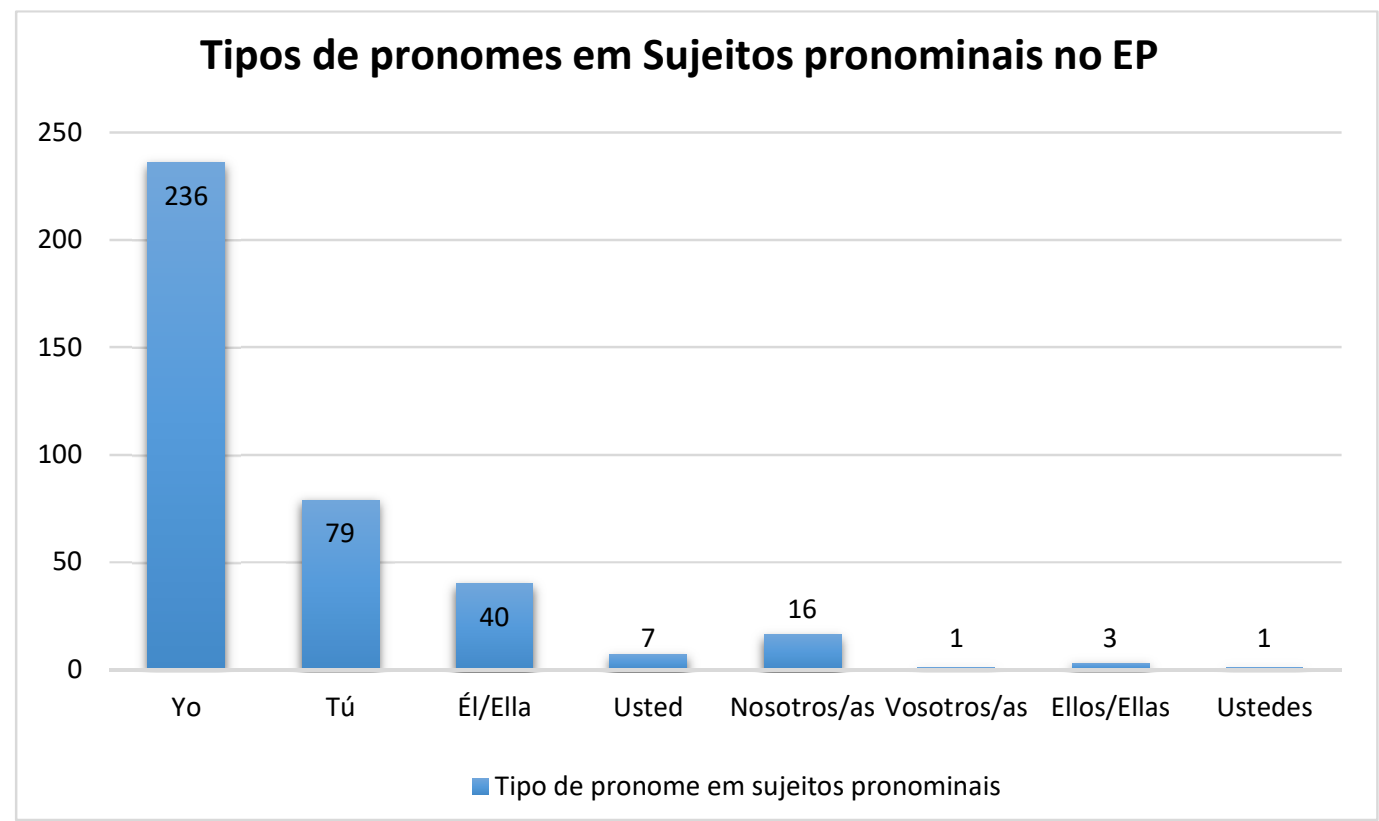

Gráfico 5 - Tipos de pronomes em Sujeitos pronominais no EP

Acreditamos, que, conforme argumenta Fanjul (2014), a funcionalidade desses pronomes Sujeito nas duas línguas ultrapasse o caráter egocêntrico da linguagem da qual falamos acima ou pode indicar valores além dos Contrastivos que apresentamos aqui. No entanto, uma descrição detalhada dessas outras funcionalidades nos levaria a estudos discursivos, que fugiriam de nossos objetivos de pesquisa atuais. Por isso, apenas indicamos, com a seguinte citação, que o que apresentamos aqui é apenas a ponta do iceberg:

No fim das contas, esses pronomes envolvem diretamente a representação da pessoa na linguagem, envolvida em todos os níveis de seu funcionamento e de seu existir como vínculo entre os seres humanos. Assim, eles são manifestações de uma categoria morfológica, mas também marcas da construção de entidades no texto, de perspectivas na enunciação, de subjetividades enfrentadas no discurso (FANJUL, 2014, p. 50)

Para nossos propósitos investigativos, no entanto, nos limitaremos a dizer que, na interlocução, o uso de um Sujeito pleno em EP, realizado em forma lexical ou pronominal, geralmente mostra tensão entre os Falantes (ou entre um Falante e alguém a quem se faz referência), divergência de opiniões. O pronome yo aparece também muitas vezes com expressões como ¿Qué sé yo? ou ¿Qué te digo/diría yo? 
No fragmento a seguir, avó (MAR) e neta (LUI) estão conversando sobre a situação dos hospitais de Madri. A avó fala que os hospitais de antigamente, os da época em que ela deu à luz a sua filha, eram precários, mas que agora, sua filha pôde conhecer bons hospitais. Trata-se, portanto, de contrapor as vivências da avó com as vivências da filha, por meio do jogo entre yo e tú. Os Sujeitos pronominais, assim, funcionam como estratégia para a marcação de Contraste. Vejamos:

*MAR: pero ése qué es \$ un hospital / <como el Doce de Octubre>?\$

*LUI: [<] <pues un hospital / cariño $>/ / \$$

*PAL: yo qué sé $/ / \$$ yo no he estado nunca en ese hospital $/ / \$$ yo he estado en el de Huercal Overa / que es donde había / en una habitación / seis / personas //\$ pero que es que / aparte de que tenían / dos dedos de mierda / los suelos y las paredes y hhh todo / es que eso es antihigiénico / cutre / \&eh $+\$ x x x$ eso no era un hospital / vamos // $\$$

\%act: (46) laugh

*MAR: pero tú porque $<x x x>+\$$

*PAL: $[<]<$ eso era> como cuando / hay guerras / y hacen campamentos $<$ de $>[/] \$$

*MAR: $[<]<$ sí> //\$

${ }^{*} P A L:$ de urgencia $/ / \$$ pues más o menos lo $<$ mismo $>/ / \$$

*MAR: [<] <pues vale> / hija //\$ porque tú por [I//] para ti por suerte / pues eso / has conocido la [/] la [/] \&ah / el Doce de Octubre $\$$

*LUI: que <cuánta potencia>\$

*MAR: $/[<]<\& e h>/ \$$

*LUI: / tiene <eso $>$ ?\$

*MAR: $/[<]<$ que son $><$ buenos $>/ / \$$

*PAL: $[<]<e l$ Doce $>/$ he conocido el $<$ San Rafael $>$...\$

*MAR: $[<]<$ claro $>/ / \$$

*LUI: $[<]<$ que cuánta potencia> no tiene eso ?\$

*PAL: he conocido muchos $/ / \$$ y no / tiene <nada que ver> $/ / \$$

\%alt: (7) na

*LUI: $[<]<x x x>/ / \$$ yo qué sé $/ / \$$

*MAR: pero / que eso que te estoy diciendo / que tú has conocido hospitales nuevos / y modernos //\$ pero \& [/] tú llegas a ver al Francisco Franco / como el Clínico que te estoy diciendo / como la maternidad de O'Donnell ...\$

*LUI: $x x x / / \$$

*MAR: claro //\$ tú te vas al [/] al Ramón y Cajal / o al / Severo Ochoa / todos esos / que son hospitales nuevos / que son virguerías //\$ pero si tú hubieras conocido las cutreces que había <en Madrid / no hace tanto tiempo> ...\$ (C-ORAL-ROM-efamcv22)

Neste fragmento, notamos que a Falante prefere usar o Sujeito pronominal em yo no he estado nunca en ese hospital //\$ yo he estado en el de Huercal Overa (eu não estive nunca nesse hospital // eu estive no de Huercal Overa), quando seria perfeitamente possível sua omissão, dado que a desinência verbal de he estado (estive) não causa ambiguidade sobre seu referente. O uso de yo, nesse caso, serve como contraponto ao que se continuará dizendo, ou seja, que a experiência ruim desse yo (avó) não é a mesma que a da filha (tú). Note-se que, do mesmo modo que 
o yo poderia ser omitido anteriormente, também seria possível omitir o tú, já que, mais uma vez, as desinências verbais e os demais pronomes (has conocido, llegas, te vas, hubieras) não possibilitam mais de uma interpretação. Concluímos, portanto, que o uso desses pronomes é uma estratégia pragmática para diferenciar Conteúdos Comunicados. Em termos de posicionamento, todos esses constituintes ocupam $\mathrm{P}^{\mathrm{I}} \mathrm{da}$ Oração a que pertencem, que seria sua posição icônica. Portanto, o Contraste não se dá por uma mudança na ordem, mas justamente em manter a ordem icônica SVO e explicitar o Sujeito. Vejamos alguns outros exemplos, dentre vários, encontrados em nosso corpus:

(110) *PIL: y [/] y bueno / eso a mí me xxx / como a una joven //\$ mira esto de las [/] la Fundación March //\$ hay unos conciertos <estupendísimos / eh>?\$

${ }^{*}$ LOL: $[<]<$ si $>/ / \$$ buenisimos $/ / \$$

${ }^{*} P I L:$ lo que pasa que son de / cultos / <xxx música $>/ / \$$

*LOL: [<] <yo iba ahí \&d> [/] en el cole //\$ cuando yo era alumna //\$ nos llevaban a la [/] <a la Fundación March $>/ / \$$ verdad $/ / \$$

${ }^{*} P I L:[<]<$ los [/] los sábados> por la mañana es / una delicia / eh ?\$ te lo digo de

${ }^{*} L O L:$ si $/ / \$$ pero $+\$$

${ }^{*} P I L:$ aunque / no puede $<$ ser $>/ / \$$

*LOL: / [<] <yo> ya / fines de semana / imposible //\$ (C-ORAL-ROM-efamdl01)

No fragmento (110), as Falantes usam o yo para demonstrar que, enquanto uma ia aos concertos na Fundação March aos sábados, a outra vê isso como impossível. Em (97), assim como em vários outros fragmentos no nosso corpus, yo aparece junto com o verbo creer (acreditar/achar), comprovando a ideia de Enríquez (1984, apud GONZÁLEZ, 1994) sobre a alta incidência de sujeitos pronominais com verbos que indiquem opinião.

(111) *MAN: $[<]<$ pero> / esa birria ahi te [/] te vale para algo?\$

\%alt: (8) pa

${ }^{*} N I E:$ no $/ / \$$ si no es por \&a [///] no //\$ si a mí no es / que me valga <por> +\$

*MAN: $[<]<$ por una> cuestión estética ?\$

${ }^{*} N I E:$ estética $/ / \$$

*MAN: \&este [I//] por la cuestión estética / yo creo que ya hace tan feo el pico / como hasta ahí //\$ es lo que / te quiero decir //\$

*NIE: sí ?\$ jah! / pues a lo mejor ganabas xxx +\$(C-ORAL-ROM-efamdl19)

Já em (112), as três participantes conversam sobre não acertarem as perguntas em um concurso televisivo que dá prêmios, dizendo que, para ganhar, teriam que usar dicionários e enciclopédias. Então, cada uma vai marcando, com o 
uso de yo, o que cada uma tem ou não tem, sempre em contraposição aos que as colegas têm ou não têm.

(112) $\quad$ *PAL: $[<]<$ por cierto> / deberíamos [///] yo tengo diccionario / pero lo que no tengo es enciclopedia $h$ hh $/ / \$$

${ }^{*} N U R: n o /<y o>+\$$

${ }^{*} P A L:[<]<$ porque $>$ claro / habrá que llevarse $/ \$$

${ }^{*} N U R$ : yo lo tengo <\&embala> [/]\$

${ }^{*} P A L:[<]<$ para hacerlo> profesionalmente / no ?\$

\%alt: (1) pa

*NUR: yo lo tengo embalado / todo //\$

${ }^{*} P A L:$ yo <tengo $>+\$$

${ }^{*} P R I:[<]<$ yo no $>$ tengo / enciclopedia //\$

${ }^{*} P A L$ : yo tengo diccionario / <pero es que después $>+\$$

${ }^{*} P R I:[<]<$ es que no la necesito $>/ / \$$ yo soy una <enciclopedia andante $>/ / \$$

(C-ORAL-ROM-efamcv07)

Esses exemplos foram apenas alguns dos muitos que apareceram em nosso corpus e nos mostraram que a função Contraste pode ser marcada em EP pela manutenção da ordem SVO desde que o Sujeito seja explícito. Isso só ocorre em PB vinculando essa estratégia à proeminência prosódica dos Sujeitos, o que equivale dizer que, em PB, é a prosódia e não a presença do Sujeito que marca o Contraste. A presença dos pronomes em PB é, geralmente, para suprir a perda de marcações morfológicas dos verbos. A falta de proeminência prosódica e, portanto, ausência da função Contraste em PB, ao menos na variante mineira, que é a que analisamos em nosso corpus, pode ser percebida muito frequentemente (embora não seja uma regra) pelo uso de formas átonas dos pronomes, típicas dos textos orais: e para ele, es para eles, cê para você e ocês ou ceis para vocês. Vejamos alguns exemplos:

(113) *GIL: né / es deve meter o pau // mas enfim // esse que é o ponto // e \&pr [/2] e principalmente / es tão querendo fazer / campeonato / sem a gente / também / então assim // espero que / isso nũ seja / coisa pros times que jogam com a gente deixar de jogar com a gente // mas +

${ }^{*} E V N$ : é //

*LEO: como o Chub fala / es vão pegar os caras que / tipo / tavam reclamando / e tal / es vão pegar / es vão pegar tentar fazer um negócio desse / e eu aposto que cê vai ver os caras que já conhecem a gente há mais tempo / tipo José [/1] Zé Mourinho / falando assim / não / o / campeonato d' ocês é bem melhor // eu nũ + tipo / eu [/1] eu acredito / tipo / cem por cento / nisso // (C-ORAL-ROM-cv01)

*MAR: <ah / cê tirou / o xerox> //\$

*MAR: a minha não / ainda es nũ me mandaram não (C-ORAL-ROM-bfamdl21) 
Observamos na primeira ocorrência em (113) - es deve - que não há marcação morfológica de plural no verbo e, por isso, poderia ser ambíguo, referindose a ele, ela, você, nós, a gente, eles, elas e vocês. Para indicar o Sujeito Tópico, portanto, foi necessário que o Falante usasse um pronome que correspondesse ao que ele queria. Para mostrar que o uso de Sujeitos pronominais é bem mais frequente em PB que em EP, fizemos a contagem de quantas vezes ocorreu o pronome eu na função de Sujeito e obtivemos 487 ocorrências (contra 236 do EP). Ou seja, em PB, esse pronome foi usado mais que o dobro do que foi usado em EP o que indica que, realmente, em EP prefere-se usá-lo (bem como os demais pronomes) primordialmente para intenções especiais.

Tudo o que expusemos neste subcapítulo, e em outras partes deste trabalho em que também abordamos a omissão dos Sujeitos lexicais em EP, especialmente os pronominais, confirma a tese de González (1994, 2008, 2014), Fanjul (2014), Groppi (2016) entre outros pesquisadores que também apontam para essa diferença entre o EP o PB, que deixam marcas nas produções de brasileiros aprendizes de espanhol como língua estrangeira:

A omissão do pronome na posição do sujeito [em E] acontece não somente na escrita mas também na fala. Esta característica dos pronomes tônicos sujeito diferencia a gramática do falante nativo de espanhol da gramática do falante brasileiro de português que, ao falar espanhol, vai ter a tendência de preencher sempre o lugar do sujeito (GROPPI, 2016, p. 115)

Antes de encerrar este subcapítulo, porém, queremos tentar interpretar tudo o que foi descrito aqui, agora do ponto de vista da tese que estamos defendendo de que o EP passa por um processo de não topicalização dos Sujeitos. Como ponto de partida de nossa argumentação, tomaremos uma reflexão de Fanjul (2014), a qual apresentamos a seguir.

Tomando por base as ideias de Chafe (1994, apud FANJUL, 2014), que apresenta uma abordagem cognitiva da linguagem e propõe que durante a interação verbal as informações na mente dos interlocutores se distingam entre dada, nova e acessível, Fanjul (2014, p. 37) conclui que "Um pronome nunca comporta informação 'nova', mas sim dada ou acessível”. Isso significa que, principalmente quando há um referente humano, o Sujeito sintático atua informativamente como o que Chafe denomina ponto de partida, ou informação nova. 
Cremos que no $\mathrm{E}$ a presença do pronome sujeito tem a capacidade de mudar o centro de interesse em direção a outro referente que já tenha sido dado e esteja acessível no contexto cognitivo dos interlocutores para agir como o ponto de partida seguinte. [...] enquanto nada indique o contrário, o referente que é "ponto de partida" se mantém, no $E$, na progressão do texto, sem necessidade de pronome que o retome. (FANJUL, 2014, p. 39)

Remodelando os conceitos usados por Chafe à GDF, de maneira geral, a informação nova não pode corresponder a um Tópico. Somente informações dadas e acessíveis é que podem ser Tópicos. As informações novas, por sua vez, podem corresponder a Comentários e a Focos (se são justamente essas informações novas as mais relevantes e que se queiram destacar). Pois bem. Se pronomes não comportam informação nova, isso significa que eles são sempre Tópicos, já que sempre são correferentes a outro constituinte expresso ou resgatado do contexto. Manter os pronomes Sujeito em PB, portanto, é uma maneira de expressar o Tópico repetidamente. É uma estratégia de manutenção de Topicalização desses Sujeitos. Assimetricamente, a não realização desses pronomes Sujeitos no EP revela que, de maneira geral, não é o Sujeito que se pretende topicalizar. É uma estratégia, portanto, de não topicalizar os Sujeitos. A presença dos pronomes Sujeito em EP, assim, só ocorre para indicar um novo Tópico na cadeia discursiva, mas quase sempre com a sobreposição da função pragmática de Contraste, que é o que entendemos da citação acima sobre esse pronome ter, portanto, a capacidade de mudar o centro de interesse em direção a outro referente (ao que está sendo contrastado).

Essa tese dos usos ou não usos dos pronomes Sujeitos tem seu espelhamento nos usos ou não usos dos pronomes Objetos nas duas línguas. Como no EP, não são os Sujeitos os constituintes que se costumam topicalizar, o que se topicaliza, nessa língua, são os Objetos. Como vimos, os Objetos são retomados por pronomes oblíquos nessa língua, mesmo em contextos informais. Isso explicaria a alta incidência desses pronomes no EP, em comparação com o PB: os clíticos (ou oblíquos) refletem a Topicalização dos Objetos, e reservam o uso dos pronomes fortes para marcar Foco e/ou Contraste ou para desambiguar algum termo. O PB, por sua vez, como tende a topicalizar os Sujeitos, tende também a não topicalizar os Objetos e, por isso, usa cada vez menos clíticos e apresenta forte preferência por Objetos vazios/nulos. Recorrer à expressão dos Objetos, assim, seria provavelmente uma 
maneira de marcar Foco e/ou Contraste ou de desambiguar algum termo. Esse raciocínio pode ser sintetizado com o sequinte quadro espelhado:

\begin{tabular}{|c|c|}
\hline EP & PB \\
\hline $\begin{array}{l}\checkmark \text { Menos pronomes Sujeito }=\text { Menos } \\
\text { Sujeitos Tópicos }\end{array}$ & $\begin{array}{l}\checkmark \text { Mais pronomes Sujeito }=\text { Mais } \\
\text { Sujeitos Tópicos }\end{array}$ \\
\hline $\begin{array}{l}\checkmark \text { Mais pronomes Objeto }=\text { Mais } \\
\text { Objetos Tópicos }\end{array}$ & $\begin{array}{l}\checkmark \text { Menos pronomes Objeto }=\text { Menos } \\
\text { Objetos Tópicos }\end{array}$ \\
\hline $\begin{array}{l}\checkmark \text { Realização de Sujeitos pronominais = } \\
\text { Foco, Contraste ou Desambiguação }\end{array}$ & $\begin{array}{l}\checkmark \text { Realização de Objetos não nulos }= \\
\text { Foco, Contraste ou Desambiguação }\end{array}$ \\
\hline
\end{tabular}

Esquema 29 - Tendências de não topicalização nas duas línguas

Entendemos que a função desambiguadora pode, muitas vezes, corresponder à função retórica de Esclarecimento proposta pela GDF, da qual falaremos no capítulo 5. Apesar dos contrastes entre o PB e o EP, há uma grande semelhança: ambas são línguas de tipologia TOP-Comentário.

Como apresentamos em outros momentos deste trabalho, já partíamos desse pressuposto para o PB, baseando-nos nos estudos de Pezatti (2014). Estendemos, agora, essa mesma constatação para o EP. Isso não significa afirmar o que tradicionalmente já se afirmou várias vezes de que as duas línguas partilham da mesma tipologia por serem do tipo SVO (o que pressuporia, am alguma medida, que os Sujeitos de ambas fossem os Tópicos).

Antes de iniciarmos nossa pesquisa, já suspeitávamos que essa ordem não fosse idêntica nas duas línguas, suspeita essa que, aliás, motivou que iniciássemos essa pesquisa, como explicamos na Introdução. No decorrer da pesquisa, no entanto, fomos constatando que a ordem OV(S) era muito mais abundante em EP do que imaginávamos. Não sabíamos, ainda, como justificar essa preferência pela posposição dos Sujeitos, que ultrapassasse questões estilísticas. O que as leituras dos diversos estudos que apresentamos aqui e das análises dos nossos dados nos mostraram é que essas ordenações diferentes nas duas línguas são reflexos de processos do Nível Interpessoal no Nível Morfossintático. Em outras palavras, a Sintaxe se mostrou claramente subjugada à Pragmática e, cognitivamente, em ambas as línguas tende-se a manter a estrutura informacional TOP-Comentário, porém, com 
diferentes recursos morfossintáticos, dentre eles a ordenação dos constituintes, a presença ou ausência de pronomes Sujeitos e de pronomes Objetos e a determinação ou indeterminação dos constituintes.

Terminamos, assim, nossa explanação sobre as três funções pragmáticas propostas pela GDF: Tópico, Foco e Contraste. Como viemos apontando em vários momentos, no entanto, é necessário, não confundir essas funções com a categoria Ênfase, da qual falaremos mais detalhadamente agora.

\section{4 Ênfase}

Segundo Pezatti (2012, p. 96)

A GDF distingue funções pragmáticas (Foco, Tópico e Contraste) de outras categorias do Nível Interpessoal, como Ênfase, Mitigação, Identificabilidade, Exatidão e Aproximação. Cada uma dessas categorias pragmáticas aplica-se a camadas específicas do Nível Interpessoal, com exceção da Ênfase que é atribuída a todos os tipos de unidades acionais: Ato discursivo, Ilocução, Conteúdo Comunicado e Subatos de Atribuição e de Referência.

Como dissemos anteriormente, na literatura linguística, a categoria pragmática de Ênfase (Emphasis) é com frequência confundida com a função pragmática Foco, isso, claro, do ponto de vista da GDF. Para esta, no entanto, a Ênfase é uma estratégia utilizada pelo Falante para atingir seu propósito comunicativo, intensificando um constituinte ou toda a Expressão Linguística. Ela tem, portanto, um lugar de proeminência, sendo entendida como uma categoria pragmática que perpassa todas as camadas do Nível Interpessoal (Ato, Ilocução, Conteúdo Comunicado e Subatos).

Operando no nível da llocução, os autores citam como exemplo a partícula dan do alemão, que é colocada no final da sentença, e serve para enfatizar llocuções imperativas. Há, ainda, línguas que expressam o operador de Ênfase morfologicamente, como é o caso do Evenki, ${ }^{145}$ que usa os sufixos $-r^{\prime} e:,-k^{\prime} e:$ ou $-e$, indicando descontentamento.

\footnotetext{
145 "Evenki é a língua mais falada dentre as Tungúsicas Norte, grupo que inclui também as línguas Even e Negigal. É falada pelos Evenkis na Rússia, Mongólia e China”. Consulta feita no site https://pt.wikipedia.org/wiki/L\%C3\%ADngua evenki. Acesso: 17 jan 2018.
} 
Segundo Hengeveld \& Mackenzie (2008), no nível do Ato Discursivo, por exemplo, pode haver um Operador Enfático. Neste caso, a própria entonação da frase, sendo exclamativa, por exemplo, pode indicar que há a intenção de enfatizá-la. No entanto, cabe esclarecer que a categoria Ênfase pode estar presente em llocuções que qualquer tipo, sejam declarativas, interrogativas, imperativas, etc. Os autores nos trazem exemplos do espanhol, em que se usa, além da llocução exclamativa e/ou interrogativa, a partícula que para enfatizar o Ato Discursivo:

(115) ¡Que no me gusta nada esa película! (HENGEVELD \& MACKENZIE, 2008, ps. 1040).

[Ø (Eu) não gosto nada desse filme!]

[Ø (Eu) detesto esse filme!]

¿iQue si vienes mañana!? (HENGEVELD \& MACKENZIE, 2008, ps. 1044).

[Ø Se você vem amanhã?]

Nesses casos, o que não é acentuado graficamente (tal como ocorreria se fosse um interrogativo ou exclamativo), já que sua função é apresentar uma Oração como reportativa, ou seja, que transmite informações em nome de outra pessoa. Notese também que as entonações das enfáticas e das reportativas não são iguais. Nesses exemplos, portanto, o operador de Ênfase que (que as gramáticas denominam expletivo) escopa todo o Ato Discursivo (e por isso ocupa $\mathrm{P}^{\prime}$ ), e "A ênfase é, portanto, o resultado da intensificação do Ato Discursivo"146 (HENGEVELD \& MACKENZIE, 2008, ps. 1040). Construções como (115) e (116) também podem ser interpretadas como elipses da Oração principal ( Te digo que... / Te pregunto [que] si..., nesta última, em variedades peninsulares como a madrilenha, se somam dois conectivos introdutórios de discurso indireto: que si) e também pode aparecer em respostas como Que sil/ Que no e em expressões como ¿[Apuesto] A que no (sabes/conoces etc.)?

De fato, constatamos em nosso corpus que esse é um recurso bastante usado no EP para marcar Ênfase (e que não está disponível em PB). Vejamos dois exemplos:

${ }^{146}$ Tradução nossa do original: Emphasis is thus the result of the Speaker's intensification of a Discourse Act. 
*PAC: $[<]<$ veintitrés> tiene ?\$

*PAT: pero vamos / que es muy joven / de todas maneras //\$ <bueno / es que [/] es que llevaba>\$(C-ORAL-ROM-efamcv05)

[mas vamos, $\varnothing$ é muito jovem]

[mas vamos, $\varnothing$ ele é muito jovem]

(118) *OÑO: $y$ estabais cerca del escenario?\$ no $+\$$ parece que te estoy haciendo una entrevista //\$ hhh //\$

*UEL: $h$ hh $/ / \$$ que yo soy el periodista aquí $/ / \$$

${ }^{*} O \tilde{N} O$ : es verdad / que el periodista es él //\$ que / estabas cerca del escenario / o os tocó bien ?\$ (C-ORAL-ROM-efamdl20)

[Ø Eu sou o jornalista aqui]

[Ø Eu que sou o jornalista aqui]

Outra maneira muito usual de marcar Ênfase, tanto em PB como em EP, é por meio do uso de construções do tipo -que ou -é que/es que, colocadas antes do constituinte a ser enfatizado. Em nossos corpora, no entanto, essas estruturas enfáticas só ocorreram em llocuções Interrogativas abertas (do tipo $Q$ ou de Conteúdo), das quais falaremos no capítulo 6.

Fontes (2018, apud BRAGA, 2009; 2013) constata que, apesar de haver a indicação de que essa estrutura esteja se gramaticalizando na língua portuguesa, ela ainda não está fixada, já que existe a possibilidade de inserção de outros constituintes entre o verbo ser e o complementizador que. Suspeitamos que esse processo de gramaticalização não ocorra em EP, como mostraremos brevemente a partir da comparação de algumas ocorrências nas duas línguas.

Vejamos primeiro alguns exemplos em PB:

(119) *MAR: e que dia que vai ser o negócio lá com a Miquelina mesmo / que ela falou //\$ (C-ORAL-BRASIL-bfamdl21)

${ }^{*}$ CAR: quem que é <esse Gilson>?// (C-ORAL-BRASIL-bfamcv12)

(121) *GIL: sabe que que eu penso / velho?//

${ }^{*} E V N$ : <não> // (C-ORAL-BRASIL-bfamcv01)

(122) *ERN: nts / como é que chama o negócio?\$ (C-ORAL-BRASIL-bfamdl21)

*MAR: onde que fica Otranto?//\$ (C-ORAL-BRASIL-bfamdI21) 
Em EP, não encontramos nenhuma ocorrência de que seguido dos pronomes interrogativos quién (como ocorre em 120 do PB) nem dónde (como ocorre em 123 do PB). Também não encontramos nenhuma ocorrência de que que (como ocorre em 121 do PB) e nenhuma estrutura que + substantivo + que (como ocorre em 119 do $\mathrm{PB})$. Essas estruturas nos parecem agramaticais à primeira vista, e por isso aplicamos um teste bastante simples de aceitabilidade dessas sentenças com hispanoparlantes nativos: tomamos os exemplos em PB e as traduzimos literalmente ao EP. Apresentamos essas traduções aos nativos e lhes perguntamos se em um contexto de conversa entre amigos, eles poderiam dizê-las ou escutá-las, ou seja, se seria possível que existissem na língua. O teste (que, devido à sua simplicidade, devemos chamar apenas de consulta) foi feito via uma rede social e respondido por 15 nativos: 2 colombianas, 1 argentina, 4 espanhóis, 6 mexicanos e 2 chilenos. As traduções literais sugeridas foram as seguintes:

(1) ¿Qué día que va a ser la fiesta?

(2) ? ¿Quién que es este Gilson?

(3) ? ¿Dónde que está Otranto?

(4) ? ¿Sabes que que yo pienso?

Com exceção da Falante argentina, que disse que a (3) Ihe soava normal, e de 1 Falante mexicano que disse que a (1) Ihe soava normal, os demais participantes disseram veeementemente que nenhuma dessas sentenças ocorreriam em seu idioma. Reproduzimos literalmente aqui algumas das respostas dadas por eles. Marcamos com (XX) o nome de uma das participantes, para preservá-la:

$\checkmark$ Suenan feísimo así!! Las 4! En mi humilde opinión.

$\checkmark$ El "que" me parece que sobra en todas!! Yo nunca las he oído así!

$\checkmark$ Hola Sol Labbonia, no, para $(X X)$ y para mí no son posibles, me parece que están en desorden.

$\checkmark$ No es posible que estén los dos que en la oración.

$\checkmark$ Nop... Nop... Y nop... No es viable... No existe el ritmo... Ni la dicción y pues menos la coherencia... Eso creo yo... Nunca las pronunciaría.

$\checkmark$ Sol Labbonia, siento que la traducción es literal a tu idioma, no hay conferencia, la estructura debe ser mejorada. 
Uma das pessoas que responderam à nossa breve pesquisa foi uma reconhecida professora e pesquisadora na área de ensino de língua espanhola. Sua resposta foi: No me suenan nada bien y yo no diría ninguna de ellas tal como están redactadas.

O teste nos indiciou que o uso de que parece, de fato, não ser uma estratégia viável para enfatizar determinados pronomes interrogativos no EP. Uma pesquisa mais aprofundada e detalhada sobre o tema poderia confirmar ou refutar o que apontamos aqui.

A única possibilidade parecida a essas do PB que encontramos em EP foi o uso de es que, como mostramos nos exemplos seguintes:

(124) //\$ y claro / la abuela / pues / cómo es que la han adelantado no sé?\$ dice no //\$ (CORAL-ROM-efamcv05)

[como é que a adiantaram não sei]

(125) y luego se ha [/] luego / no sé quién se lo dijo / que es que estaba embarazada //\$ (C-ORAL-ROM-efamcv05)

[não sei quem $\varnothing \varnothing$ disse que é que estava grávida] [não sei quem que disse isso, que ela estava grávida]

Notamos pelas traduções de (124) e (125) que o operador enfático es que, disponível no E não é possível de ser usada da mesma maneira em PB. Como vimos, em PB, a estrutura é que funciona como operador para marcar Foco Contrastivo, em estruturas clivadas, nas quais o elemento focalizado se posiciona à esquerda desse operador, e não à direita como vemos em EP, em sentenças como Ela é que está grávida (e não outra mulher). Uma observação é que as estruturas es que do EP, ao menos em nosso corpus, só apareceram encabeçando sentenças complexas e não apenas Sintagmas.

Hengeveld \& Mackenzie (2008, ps. 5291) chamam atenção ainda para a possibilidade que existe em algumas línguas de marcar a Ênfase com uma frasefonológica com entonação proeminente funcionando como Operador, como se vê em:

(126) Horrible!

(127) Really?? 
Poderíamos adaptar (126) e (127) ao PB com expressões como Credo/que horror!!! e Sério?? e ao espanhol com expressões que poderiam ser, dependendo do contexto, ¡Qué asco/espantoso! e ¿En serio?

Como se veio mostrando até aqui, a Ênfase deve ser distinguida das funções pragmáticas Tópico, Foco e Contraste, apesar de que tanto Foco quanto Ênfase e Contraste serem recursos de saliência. No entanto, um dos critérios essenciais para distingui-los, como vimos nos exemplos, é a possibilidade de enfatizar tanto Tópicos como Focos. Além disso, a Ênfase, nas línguas que analisamos, está muito mais relacionada a usos de operadores e entonação, que propriamente à ordenação dos constituintes (e por isso, trazemos esse tema aqui somente para diferenciá-lo das funções de Foco e de Contraste, que são as que verdadeiramente nos interessam).

Terminamos aqui nosso capítulo sobre as funções Pragmáticas na GDF. Resta-nos, ainda, abordar algumas questões relativas à ordenação dos constituintes com funções Retóricas, especialmente de duas delas: a Orientação e o Esclarecimento. É sobre isso que versará o próximo capítulo. 


\section{CAPÍTULO 5}

\section{AS FUNÇÕES RETÓRICAS DE ORIENTAÇÃO E DE ESCLARECIMENTO}

Algumas construções que são muito usadas no discurso oral, ou seja, que fazem parte da Expressão Linguística, não fazem parte da Oração, sendo, portanto, constituintes extraoracionais. Há diversos tipos de unidades pertencentes à Expressão Linguística, tais como orações Sintagmas ou Palavras. Segundo Pezatti (2017), se houver mais de uma unidade na Expressão Linguística, elas terão as mesmas propriedades morfossintáticas umas das outras. Isso permite, por exemplo, a combinação de Orações, ${ }^{147}$ a combinação de Sintagmas ${ }^{148}$ e a combinação de Sintagmas e Orações.

A combinação de dependência comunicativa entre um Ato Discursivo subsidiário com outro, Nuclear, ou de um Sintagma (que também será dependente) e uma Oração (independente) é um processo denominado extraoracionalidade. $\mathrm{Na}$ verdade, a GDF atribui o termo extraoracionalidade somente à relação de Sintagmas como constituintes extraoracionais, que dependem do Ato Discursivo Nuclear. Nossa interpretação, no entanto, nos fez incluir neste termo construções compostas, como as que explicaremos na sequência.

Esses elementos extraoracionais vão ocupar, portanto, posições marginais à Oração, como vimos anteriormente: a Pre e a Pos (e suas posições relativas). Essas posições podem abrigar modificadores e operadores de Movimento e de Ato Discursivo, além de constituintes com funções retóricas.

Segundo Hengeveld \& Mackenzie (2008, ps. 780),

A retórica preocupa-se fundamentalmente com as maneiras pelas quais os componentes de um discurso são ordenados para a realização da estratégia comunicativa do falante, e também com as

147 Por exemplo: Eu acho que ele é bem comunicativo...apesar de tímido (AC-82-NE, 85, apud PEZATTI \& CAMACHO, 2017, p. 162).

148 Por exemplo: L2: por favor, o seu nome? (Moç97:Maternidade apud PEZATTI \& CAMACHO 2017, p. 164). 
propriedades formais de enunciados que influenciam o Destinatário a aceitar os propósitos do Interlocutor. Por essa razão, os aspectos formais das unidades linguísticas que refletem a estruturação geral do discurso serão explicados na GDF em termos de funções chamadas retóricas. ${ }^{149}$

Complementando a citação acima, trazemos as palavras de Pezatti \& Camacho (2017, p. 165):

A Retórica está fundamentalmente relacionada às propriedades formais de enunciados que influenciam o destinatário a aceitar os propósitos do falante e aos modos pelos quais ele ordena os componentes de um discurso para a realização de sua estratégia comunicativa. Por isso, os aspectos de unidades linguísticas que refletem a estruturação global do discurso são considerados funções retóricas que se aplicam a Atos Discursivos, uma das unidades do nível interpessoal.

A GDF propõe que haja cinco funções retóricas: Orientação, Esclarecimento, Concessão, Motivação e Aposição. Dentro dos limites que nos impusemos para este trabalho, nos interessa explicar as duas primeiras. Segundo Pezatti (2017), em PB, a Ppre da Expressão Linguística é a mais adequada para abrigar a função retórica de Orientação, enquanto a Ppos aloca as funções retóricas Esclarecimento, Concessão e Motivação.

Em um texto que abre uma sessão de comunicações em um congresso, cujo tema eram as funções pragmáticas dentro da teoria dikiana (nessa vertente teórica, o que a GDF chama funções retóricas, eram chamadas de funções pragmáticas extraoracionais), Pezatti (s.d, p. 214) diz que esses constituintes possuem as seguintes propriedades:

1. podem preceder, interromper ou seguir a oração; 2. são tipicamente separados da oração por uma pausa entonacional própria; 3. não são sensíveis às regras gramaticais da oração, embora possam estabelecer relações de correferência, paralelismo (mesma marcação de caso) ou metátese com a oração a qual eles estão associados; 4. não são essenciais à integridade interna da estrutura da oração, isto é, quando são subtraídos, a oração conserva a sua integridade estrutural e gramatical.

${ }^{149}$ Tradução nossa do original: Rhetoric is fundamentally concerned with the ways in which components of a discourse are ordered towards the achievement of the speaker's communicative strategy, and also with the formal properties of utterances that influence the Addressee to accept the Speaker's purposes. For that reason, those formal aspects of linguistic units that reflect the overall structuring of discourse will be accounted for in FDG in terms of rhetorical call functions. 
Embora se trate de uma teoria pré-GDF, sabemos que muito do que se propõe na GDF tem sua fonte no funcionalismo de Dik (1981, 1989, apud PEZATTI, 2008). Por isso, parece-nos que essas características elencadas acima podem, perfeitamente, ser aplicadas ao que a GDF propõe como funções retóricas. Queremos destacar, ainda, um dos pontos acima: a de que esses constituintes não são sensíveis às regras gramaticais da Oração, pelo que entendemos que não desempenham nenhuma função sintática na Oração, o que justifica nossa fala mais adiante de que a Oração (ou o Ato Discursivo nuclear) está sintaticamente completa. A relação entre esses constituintes extraoracionais e os intraoracionais, portanto, está no âmbito discursivo, isto é, da retórica.

\subsection{As pilhas, eu coloquei aqui x Las pilas, las puse aquí: a função Orientação}

Segundo Pezatti \& Camacho (2017, p. 165-166),

A função retórica Orientação aplica-se a um Ato Discursivo para indicar ao destinatário a intenção do falante de introduzir um referente no discurso, que é importante para a interpretação do Ato Discursivo seguinte, proporcionando, assim, uma interação coerente. Essa função fornece, portanto, um "ancoramento" consistente do Ato Discursivo nuclear, ao introduzir a entidade que servirá de suporte para a interpretação adequada dele, introduzido na sequência.

O esquema abaixo representa o padrão de ordenação, no nível da Expressão Linguística, de um enunciado constituído pela função retórica Orientação:

\begin{tabular}{|c|c|}
\hline Ppre & Pcentro \\
\hline Orientação & Oração \\
\hline
\end{tabular}

Esquema 30 - Esquema básico da Orientação

Hengeveld \& Mackenzie (2008, ps. 898) trazem o seguinte exemplo para ilustrar o que é a Orientação (Orientation): 
O constituinte meu irmão tem sua autonomia como Ato Discursivo uma vez que podemos atribuir-Ihe uma llocução diferente da que tem, como, por exemplo, uma llocução Interrogativa, em que não há ambiguidade de que há correferencialidade entre o constituinte extraoracional e o pronome ele (oracional com função Inativo):

\section{Meu irmão? Eu prometo não trair ele.}

A função de Orientação, portanto, serve para '[...] 'preparar a cena' para a interpretação do Ato Discursivo seguinte [...]" (PEZATTI \& CAMACHO, 2017, p. 167) e está composta por dois Atos Discursivos, cada um deles com sua llocução, sendo um deles nuclear (o correspondente à Oração) e o outro dependente do primeiro (o constituinte com a função retórica). Essa relação de dependência indica que há uma relação pragmática entre esses dois Atos Discursivos e, por isso, o elemento que indica a Orientação é retomado de alguma maneira no Ato Discursivo Nuclear (seja por constituintes lexicais ou por anáfora zero). Quando a retomada se dá por meio de anáfora zero, ocorre o que a tradição gramatical denomina Anacoluto, e quando a retomada se dá por meio de itens lexicais, ocorre o que a tradição gramatical denomina Pleonasmo (ou Sujeito Duplo). Pela perspectiva da GDF, não há diferenciação entre construções que são ou não são retomadas explicitamente no Ato Discursivo Nuclear.

Julgamos conveniente retomar alguns conceitos e diferenciar melhor as funções Tópico e Orientação, visto que ambas são funções do Nível Interpessoal e visto também que a Orientação corresponde ao que outras vertentes teóricas chamam de Tópico. Alguns critérios de diferenciação são:

\footnotetext{
150 Tradução nossa do original: My brother, I promise not to betray him. Preferimos não traduzir por traílo, para manter a coloquialidade típica dos textos orais. O fato de a llocução ser Declarativaa faz ambígua em português, pois o termo meu irmão pode ou não ser vocativo e, portanto, correferente ou não ao pronome ele/lo. Na segunda sentença, a llocução Interrogativa desfaz a ambiguidade e mostra que a pessoa está falando com alguém que deve ter-lhe feito uma pergunta, à qual ela responde falando sobre o próprio irmão. Neste caso, fica claro que meu irmão e ele/lo são correferentes e meu irmão não é vocativo, mas sim o tema do que se falará depois, funcionando como a Orientação, portanto, para o próximo Ato Discursivo: não vou trair ele.
} 
(i) a função Tópico é atribuída a um Subato Referencial, o que significa que constituintes com essa função fazem parte de um Ato Discursivo: são oracionais, já que ocupam uma das posições da Pcentro, enquanto a função Orientação é, em si, um Ato Discursivo (dependente de um Ato nuclear) e, portanto, os constituintes com essa função ocupam uma posição fora de Pcentro (especificamente, a Pre);

(ii) o Tópico, por ser uma função pragmática, é uma estratégia para ocasionar alguma mudança na informação do Destinatário (em vista das expectativas que o Falante tem sobre o atual estado mental do Destinatário). Já a Orientação, por ser uma função retórica, é uma estratégia discursiva para alcançar a aceitação/preparação do que será enunciado;

(iii) o Tópico formado por constituintes Configuracionais ${ }^{151}$ não é marcado por pausa ou mudança de tessitura, pois faz parte da llocução do Ato Discursivo a que pertence. Já a Orientação é marcada por pausa ou mudança de tessitura, pois tem sua própria llocução, que pode, como vimos, ser Interrogativa, ao mesmo tempo em que a llocução do Ato Discursivo nuclear pode ser Declarativa, por exemplo.

A função de Orientação da GDF corresponde ao que Gutiérrez Ordóñez (1997) chama de Tópico, Marco ou Circundante e, que, segundo o autor, está muito próximo do conceito de Tema de Dik (1997). As explicações para a função que ele chama de Tópico, portanto, se aplicam ao que a GDF chama de Orientação e, por isso, nos basearemos em suas análises para explicar os dados em EP. Basicamente, essa função, para ele, introduz uma entidade ou conjunto de entidades sobre as quais a predicação seguinte fará referência. Além disso, tem sua própria entonação e é o termo que abre o enunciado. No entanto, segundo o autor, esse não pode ser o critério para identificar essa função, já que essa posição também pode ser ocupada por constituintes com outras funções. Uma das características dos constituintes com função de Orientação é que eles são opcionais. E, por último, sua característica mais importante é a separatividade.

151 Fazemos a distinção aqui dos Tópicos formados por modificadores e que indicam o setting dos EsCos, que podem ser marcados por pausas. Mas, como já dissemos, esse tipo de Tópico não é alvo de nossa pesquisa. 
As ocorrências abaixo exemplificam casos em que os constituintes com função retórica são retomados pronominalmente na Oração Nuclear:

(3) *BRU: mas a sua bolsinha é linda hhh // gente / o Tommaso / durante o negócio / ele tava vendo jogo de futebol na internet / cê acredita // (C-ORAL-BRASIL-bfamcv22)

(4) *VER: <aí / ela> tem que subir um metro / e tal / pra poder chegar na altura do chuveiro // tanto que os chuveiros daqui de baixo / que já tão na altura / diferente / eles têm a água mais forte // (C-ORAL-BRASIL-bfamcv12)

(5) *VER: <mas assim> / o projeto lá / que o João fez / \&e [/1] ele podia assim / finalizar ele / né // mas / ele acha que ele nũ pode finalizar (C-ORAL-BRASIL-bfamcv12) ${ }^{152}$

(6) *JON: <meu vô / meu vô teve uma época> que ele tava / assim / só com [/2] depois que e' parou de trabalhar / essas pessoa que vive em trecho aí / eas bebe demais // (CORAL-BRASIL-bfamcv13)

Como vemos, em nossos exemplos, de (3) a (6), todos os constituintes com função retórica Orientação (o Tommaso / os chuveiros aqui de baixo / os projeto lá que o João fez / meu vô / essas pessoas que vive em trecho aí) são correferentes a outros constituintes, oracionais, expressos por meio de pronomes pessoais tônicos (em tese, próprios para o caso nominativo, mas que no PB podem ocupar posições de Inativos: ele, eles, elas), ou pela própria repetição do termo retomado (meu vô), todos destacados nos exemplos por um grifo. Essa característica de retomada, bastante frequente no $\mathrm{PB}$, será um fator interessante de comparação com EP, como veremos logo mais adiante.

O fato de as Orientações serem constituintes extraoracionais pode ser verificado, nos exemplos, pelo uso da barra simples ( / ) depois de cada constituinte com essa função. Como vimos no capítulo 1, esse símbolo indica que houve uma pausa prosódica não final, o que assinala, portanto, a clara separação desses constituintes do restante da Expressão Linguística. ${ }^{153} \mathrm{Em}$ comparação a esse fato, constatamos que os constituintes com função Ativo/Sujeito ou Inativo, por serem

152 Nesta ocorrência, temos o constituinte o projeto lá, com função retórica de Orientação e que é especificado pela Oração que o João fez, que, por sua vez, é retomada pelo pronome ele colocado à esquerda do predicado, marcando Inativo (ele podia assim finalizar) e o constituinte com função de Orientação é retomado pelo segundo uso de ele (finalizar ele), agora com função de Inativo.

153 A Orientação não precisa, necessariamente, ser marcada por pausa: ela pode ser marcada por um acidente prosódico, ou seja, por uma mudança na tessitura. De qualquer modo, tanto essa mudança de tessitura como as pausas podem ser verificadas nos arquivos de áudio. 
Configuracionais e fazerem parte da Oração, não aparecem nas transcrições separados por (/ ).

Outra característica que demonstra que as funções retóricas constituem um Ato Discursivo diferente da Oração Nuclear é a possibilidade de inserção de outros constituintes de diferentes tipos entre essas duas unidades, como expressões compostas de material lexical invariável que funcionam para, por exemplo, averiguar se a interação está funcionando (neste caso, o Falante pode recorrer a expressões como, por exemplo, sabe? ou entendeu?), de atrair a atenção do ouvinte (com expressões como olha e viu) ou até mesmo com a intenção de fazer uma correção do Ato enunciado anteriormente por ele (com expressões como isto é ou quer dizer). É o que ocorre no exemplo seguinte, em que entre a Orientação (isso) e a Oração (é só soldar de novo) há a expressão tipo assim:

${ }^{*} B A L$ : <cê pode> deixar o cabo bater no chão // mas essas pontas jamais //

*BEL: é não / tem cara que quebra / ou / pelo menos / dá um + tipo / solta / <né> // *BAL: <dá mau> contato // eu já \&pe [/3] eu já <quase> \&per + mas isso / tipo assim / é só soldar de novo // mas até achar <alguém que vai> <soldar isso> / cobrando só cinco reais // *BEL: <ah não> // <mas também / é> // (C-ORAL-BRASIL-bfamdI02)

Diferentemente dos exemplos anteriores, notamos que em (7) o constituinte

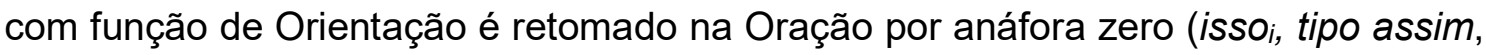
é só soldar $\emptyset_{i}$ de novo). O mesmo ocorre em (8), em que o termo as pilhas, ocupando Pre e sendo Orientação, é retomada por anáfora zero na sequência:

(8) $\quad$ *BAL: <que que eu tava pensando \&a [/6] que que> eu tava pensando aqui //\&a [/1] não // as pilhas / eu coloquei aqui // as recarregáveis / tão aqui // (C-ORAL-BRASILbfamdI02)

Nós propomos que é possível, também, que a Orientação possa ser constituída por um núcleo e construções dependentes, especificativas ou explicativas, ou às que equivalem ao que em outras abordagens teóricas se denomina sentenças relativas e que, portanto, funcionam como modificadores do núcleo. Como já dissemos, sentenças desse tipo não compõem os objetivos de pesquisa neste trabalho e, se algumas vezes trazemos exemplos em que essas ou outras construções complexas/dependentes ocorrem, é somente para esclarecer algum conceito que nos interessa no momento. É o que ocorre em (5), com a expressão que o João fez (em o projeto lá / que o João fez) e em (6), com a expressão que vive em trecho aí (em essas 
pessoa que vive em trecho aí). Em (5), a função explicativa é marcada pela pausa (assinalada pela barra simples) entre o Sintagma Nuclear (o projeto lá) e o constituinte oracional que o explica (que o João fez), enquanto a falta de pausa entre o Sintagma e o constituinte oracional em (6) indica que se trata de uma especificação.

Portanto, vemos que, apesar de serem Atos Discursivos dependentes, as Orientações também podem ter elementos Nucleares (não oracionais), seguidos de construções que podem ser verbais, mas que não lhe garantem ainda o estatuto de Ato Discursivo independente. Argumentamos que esses casos não devem ser tratados do mesmo modo como os de combinações de Orações, mas sim como combinação de Atos Discursivos, uma vez que indicam uma função retórica, ou seja, que apresentam um constituinte usado pelo Falante para ancorar seu Ato Discursivo nuclear; esse constituinte, mesmo que composto por um núcleo e uma construção especificadora ou explicativa, deve, segundo nossa interpretação, ser considerado como uma unidade.

Vejamos a representação esquemática da ordenação de (3):

\begin{tabular}{|c|c|c|c|c|}
\hline $\begin{array}{c}\text { Ato } \\
\text { Discursivo } \\
\text { Independente } \\
\text { (vocativo) }\end{array}$ & $\begin{array}{c}\text { Pre } \\
\text { ORIENTAÇÃo }\end{array}$ & P $^{\text {pre+1 }}$ & $\begin{array}{c}\text { Pcentro } \\
\text { (Oração) }\end{array}$ & $\begin{array}{c}\text { Ato Discursivo } \\
\text { independente }\end{array}$ \\
\hline gente & o Tommaso & $\begin{array}{c}\text { durante o } \\
\text { negócio }\end{array}$ & $\begin{array}{c}\text { ele tava vendo o } \\
\text { jogo de futebol } \\
\text { na internet }\end{array}$ & cê acredita? \\
\hline
\end{tabular}

Como dissemos antes, o domínio de Pre pode ser ocupado também por modificadores de Atos Discursivos, que é o que ocorre com o constituinte durante o negócio, que ocupa $P^{p r e+1}$ por já haver um constituinte com função retórica ocupando a posição absoluta (e como vimos anteriormente, constituintes com funções têm prioridade de posicionamento sobre constituintes sem funções).

Vejamos mais alguns exemplos de Orientação em PB:

(9) *JUN: <Deus> / ele é vida / realmente // (C-ORAL-BRASIL-bfamcv15)

(10) *GIL: [2] <ô / mas> / voltando à questão / falando em e também falando em povo mascarado / esse povo do Galáticos é muito palha / eu acho que es nũ deviam mais participar / e <tal> // (C-ORAL-BRASIL-bfamcv01)

${ }^{154}$ Formado por cê em $\mathrm{P}^{\mathrm{I}}$ (sendo o Tópico) e acredita em $\mathrm{P}^{\mathrm{M}}$. 
(11) *CAD: não / ou / por falar em silicone / a minha vizinha colocou silicone // (C-ORALBRASIL- bfamcv20)

Os exemplos (10) e (11) nos mostram que o PB dispõe de expressões que servem para abrir novos temas de conversa, como falando em e por falar em, servindo, portanto, como Orientação para o próximo Ato Discursivo (esse povo do Galáticos é muito palha / a minha vizinha colocou silicone). Em EP também há expressões como en cuanto a / lo de / eso de que parecem ter essa mesma funcionalidade do PB e que também indicam Orientação, como mostramos abaixo:

(12) *PIL: / y vas corriendo todo el día / andas corriendo de clase //\$ y de teatro [/] lo del teatro / lo has dejado <mucho>?\$ (C-ORAL-ROM- efamdl01)

[Sobre/em relação ao teatro, você o deixou muito?]

[Por falar em teatro, você abandonou muito?]

Aqui, vemos que o Falante recorre à estrutura $L O D E$ + Nome (el teatro) para compor o constituinte que ocupa a Pre e que tem a função retórica de Orientação, que não faz parte da llocução Interrogativa, tendo sua própria llocução, e que anuncia um referente no discurso, funcionando como ancoramento/remissão catafórica ao que se enunciará na sequência: ¿lo has dejado mucho?. O constituinte lo del teatro, portanto, é um Ato Discursivo subsidiário retomado na Oração (Ato Discursivo nuclear) pelo clítico lo (grifado). Esse recurso foi bastante recorrente no nosso corpus para a marcação de Orientação, do mesmo modo que a estrutura ESO DE + Nome, como mostramos em alguns outros exemplos:

(13) *ELE: / a ver //\$ Lo de la sierra / fue superagobiante (C-ORAL-ROM-efamdl08).

[Sobre a serra, foi super cansativa]

(14) *MAN: Lo de la puerta / eso ya lo [I//] se ha decidido / que lo vamos a hacer así // (C-ORAL-ROM-efamdl19). assim]

[Sobre o negócio da porta, isso já o ...foi decidido que vamos fazê-lo/fazer (ele)

(15) *NIE: pues eso de la cocina / tenemos que mirar / a ver cómo / lo organizamos (CORAL-ROM-efamdl19). 
[pois isso/essa história da cozinha, temos que ver como o organizamos/organizamos(isso)]

Nesses três exemplos, os constituintes em negrito têm a função de Orientação, separados da Oração por uma pequena pausa ou mudança prosódica (característica essencial para a identificação dessa função), como se pode comprovar pelos áudios. Apesar de não precisar ser retomado de maneira explícita na Oração (como ocorre em 13), as Orientações, em sua maioria, são retomadas por um clítico ou por um pronome, como ocorre em (14), cuja Orientação é retomada tanto pelo constituinte eso como pelo constituinte lo. Acreditamos que em (13) não haja retomada devido ao tipo de construção, que é de identificação, com EsCo [-dinâmico] e verbo ser. No entanto, como explicaremos a seguir, há outras características nas sentenças que são mais ou menos propícias para que as duplicações ocorram.

Gutiérrez Ordóñez (1997, p. 48) traz o seguinte trio de sentenças para diferenciar Tópico, Orientação e Foco (já adaptando os termos que o autor usa aos que adotamos aqui):

(16) Esas tonterías, Juan las dijo ante el Rector.

[Essas bobagens, Juan (as) disse diante do Reitor]

(17) Esas tonterías las dijo Juan ante el Rector. Reitor]

[Essas bobagens as disse Juan diante do Reitor/foram ditas pelo Juan diante do [Essas bobagens o Juan disse diante do Reitor]

¡Esas tonterías dijo Juan ante el Rector!

[Essas bobagens disse Juan diante do Reitor]

[Essas bobagens o Juan disse diante do Reitor]

Segundo o autor, em (16), o termo esas tonterías tem a função de Orientação; em (17), de Tópico e em (18) de Foco. Como vimos no capítulo 4, a colocação de um Objeto em $\mathrm{Pl}^{\mathrm{I}}$ que não é retomado por clítico, é o que diferencia, no nível Morfossintático, Tópico e Foco. Agora vemos que o uma característica que diferencia Orientação e Tópico, é a presença de pausa ou mudança de tessitura para o primeiro caso (marcada graficamente no exemplo 16 pela vírgula) e a ausência dessa pausa no segundo (17). 
Gutiérrez Ordóñez (1997) afirma que a referencialidade dos constituintes com função de Orientação em E é um fator que sempre se cumpre, embora não possamos nos limitar a um conceito de referência identificável. Essa referência não identificável pode, segundo o autor, se manifestar por meio de constituintes não contáveis com a função de Orientação, como no seguinte exemplo, que adaptamos:

Vino, jamás he tomado.

[Vinho, jamais tomei]

Em (19), o fato de vino (vinho) ser um substantivo incontável não é o que determina a ausência do clítico na Oração, mas sim o fato de esse constituinte não ser definido/específico, ou seja, ser um nome nu, como discutimos na seção sobre Tópico. Vejamos outro exemplo, dado pelo autor, em que o constituinte com função de Orientação (caviar iraní) é retomado pelo clítico na Oração (lo), por ser, neste caso, específico/determinado, apesar de ser incontável:

$$
\text { Caviar iraní, jamás lo he comido (GUTIÉRREZ ORDÓÑEZ, 1997, p. 49). }
$$

[Caviar iraniano, jamais o comi]

[Caviar iraniano, jamais comi]

Gutiérrez Ordóñez (1997, p. 49) é claro ao dizer que, para a função de Orientação, "Também não importam as diferentes manifestações da denotação (definida/indefinida, específica/inespecífica, genérica/não genérica....). ${ }^{155}$ Isso significa que, diferente de Tópico, que como vimos sempre precisa ser determinado/especificado, a Orientação pode ser genérica (representada inclusive por um nome nu), pode ser indefinida e inespecífica. Esses traços, no entanto, vão determinar o tipo de retomada na Oração: lexical/pronominal ou nula. Se o constituinte com função de Orientação é determinado/específico, ele corresponderá ao Tópico da Oração e, por isso, não pode ser retomado por anáfora zero, mas sim de modo explícito, como ocorre em (20). Nossa interpretação, portanto, é que (20) seja um Movimento composto por dois Atos Discursivos: Orientação + Ato Discursivo nuclear, e que a Oração esteja composta por um Tópico $(l o)$ + um comentário (jamás he (definida/indefinida, específica/inespecífica, genérica/no genérica...) 
comido). Porém, se o constituinte com função de Orientação é indeterminado/inespecífico/genérico, ele não corresponderá ao Tópico da Oração e, por isso, é retomado apenas por anáfora zero, como ocorre em (19). Nossa interpretação, portanto, é que (19) seja um Movimento composto por dois Atos Discursivos: Orientação + Ato nuclear, e que a Oração seja apenas um comentário sobre a Orientação.

Uma observação que convalida essa interpretação é o fato de os Sujeitos, que iconicamente seriam os Tópicos das Orações, se manifestarem como nulos, ou seja, há outra vez a não topicalização dos Sujeitos em E. Assim, tanto em (19) como em (20), o Sujeito yo (eu) fica omitido, já que não é de um eu que se falará, mas sim do vinho e do caviar. Lembramos, aqui, que do que se fala pode referir-se tanto a Tópicos como a Orientações.

É importante observar que, segundo nossa análise, o critério de retomada por clíticos, tanto para Tópico como para Orientação, é o mesmo somente no caso de que em Pre se aloquem constituintes correferentes à função sintática de Objeto da Oração. Quando são correferentes ao Sujeito, acreditamos que não se realizam da mesma maneira, como começamos a mostrar a partir de mais dois exemplos trazidos por Gutiérrez Ordóñez (1997, p. 49):

$\left(21 a^{156}\right)$ La mujer que buscabas, creo que está en la tienda.

[A mulher que procuravas, acho que está na loja] [A mulher que você procurava, eu acho que ela está na loja]

(22a) El hombre del paraguas, tiene malas costumbres.

[O homem do guarda-chuva, tem maus costumes]

[O homem do guarda-chuva, ele tem maus costumes]

Percebemos que em (21a) e (22a) os constituintes que ocupam Pre em E, apesar de serem específicos/determinados, não são retomados por pronomes nem por nenhum lexema na Oração, até porque, lembremos, o verdadeiro Sujeito no E é a desinência verbal. Isso também pode ocorrer em PB, em contextos mais formais e com menor frequência. No entanto, o chamado Sujeito duplo no PB, ou pleonástico, é cada vez mais frequente, como apontam diversos estudos e como já explicamos no

156 Adicionamos aqui a letra a para esses exemplos, pois logo mais adiante os retomaremos, com uma recriação correspondendo aos exemplos (21b) e (22b). 
cap. 4. Por isso, acreditamos que, nesses casos, a retomada da Orientação por anáfora zero no $E$ não tenha relação com os traços [+/-definido] ou [+/-específico] desses constituintes, mas sim com o fato de eles corresponderem, em termos referenciais, ao que seria o Sujeito da Oração, e não mais ao Objeto, como ocorre nos exemplos (19) e (20).

González (1994), de uma perspectiva teórica diferente da adotada aqui, também já havia observado algo semelhante ao que estamos defendendo aqui, quando disse que "Parece ser um fato que as construções à esquerda em espanhol só ocorrem com SNs definidos, enquanto os casos de Topicalização só admitem SNs indefinidos nessas posições" (GONZÁLEZ, 1994, p. 204). Se adaptarmos o que diz a pesquisadora aos moldes da GDF, concluímos que o que ela denomina deslocamento à esquerda é o que denominamos aqui de Tópico. E o que ela denomina Topicalização é o que denominamos aqui de Orientação.

Por esses motivos, González (1994, p. 205) já apontava que sentenças como Dinero, me parece que Juan no lo tiene [Dinheiro, acho que Juan não o tem] / [Dinheiro, eu acho que o Juan não $\varnothing$ tem] ou El libro, me parece que Juan tiene $\varnothing$ [O livro, acho que o Juan tem] / [O livro, eu acho que o Juan tem (ele)] são agramaticais no E. Nos dois casos, os constituintes que ocupam Pre são Orientações (dinero e el libro). Vemos que é possível orientalizar tanto constituintes definidos (el libro) como indefinidos (dinero). No entanto, só os definidos podem ser retomados por clíticos. $O$ que estamos propondo aqui é que a função pragmática desses constituintes é que, de fato, licencia ou não as retomadas, uma vez que só nomes nus (como dinero) não podem ser Tópicos. Trata-se, portanto, de falar o que já foi dito, mas sob outro viés: o da pragmática. É a pragmática que determina a estrutura morfossintática (presença vs. ausência de clítico, neste caso).

Reinterpretando a constatação da pesquisadora com base nos dados e em outras concepções que apresentamos aqui, nossa interpretação é a seguinte: em $E$, quando constituintes que desempenham ou desempenhariam a função sintática de Objetos na Oração é que são os elementos com função de Tópico ou de Orientação, a anáfora é lexical ou pronominal caso os constituintes retomados sejam [+determinados] e [+específicos]. Se, no entanto, na função de Orientação temos um constituinte correferencial ao Sujeito da Oração, esses traços são irrelevantes e não há retomada por pronomes fortes. Lembramos, ainda, como vimos anteriormente, que se o constituinte Sujeito for Tópico, ele sempre será retomado por pronome e sempre 
terá os traços [+determinado] e [+específico]. Caso ele seja o Sujeito ou o Objeto, mas não seja retomado e tenha os traços [-determinado] e [-específico], terá a função pragmática de Foco.

Por isso, se fôssemos traduzir nosso exemplo (6) do PB ao E, apenas para exemplificar como os constituintes correferenciais a Objetos se orientalizam ${ }^{157}$ nas duas línguas, teríamos: as pilhas, eu coloquei aqui $\rightarrow$ las pilas, las coloqué aquí. Vemos que em $\mathrm{E}$, obrigatoriamente o constituinte orientalizado teve que ser retomado pelo clítico las, enquanto no PB, a Orientação foi retomada por um $\varnothing$ (embora, como vimos, também pudesse ser retomada por um pronome forte ${ }^{158}$ em contextos informais: as pilhas, eu coloquei elas aqui, e por clítico, em contextos formais: as pilhas, eu as coloquei aqui).

Nós retomaremos essa discussão logo mais adiante, quando falarmos sobre o Parâmetro do Objeto nulo e usarmos esse critério para as comparações com o EP. Antes, porém, vejamos mais alguns exemplos de Orientação em EP do nosso corpus:

*MAR: vale $/ / \$$ perfecto $/ / \$$

${ }^{*} R A U$ : entonces / \&eh / estos conjuntos / nosotros / ya / lo que hacemos es fabricarlo ${ }^{159}$ / \&cu [/] pues con las [/] las características del equipo de bombeo que te piden / (C-ORAL-ROM-efamdl33)

[estes conjuntos, nós, (já), o que fazemos é fabricá-lo/ele]

(24) *FUE: y además / que no están tampoco tan bien diseñados / como para [/] como para correr / a esas velocidades //\$ es solamente / fantasmada //\$ pero todos esos coches / pues eso / los Lamborghinis / todos los Ferraris estos / cuando los meten en los circuitos / se quedan atrás //\$ (C-ORAL-ROM-epubdl09)

[os Lamborghinis, todas as Ferraris essas, quando os colocam nos circuitos, ficam pra trás]

[os Lamborghinis, todas essas Ferraris, quando colocam elas nos circuitos, (elas) ficam pra trás]

Em (24), temos o uso do clítico los (los meten) para retomar um Objeto préverbal (todos esos cocheslos Lamborghinis / todos los Ferrari estos). Esse clítico é

157 Criamos o verbo orientalizar, para indicar a ação de atribuir a função de Orientação a um constituinte, em paralelismo aos termos já conhecidos para outras funções pragmáticas: topicalizar e focalizar e para não ser ambíguo com o verbo orientar.

158 Os pronomes fortes são os não clíticos, ou seja, aqueles que a tradição gramatical denomina de pronomes pessoais do caso reto.

159 Percebemos aqui a falta de concordância de número entre o clítico e o termo que ele retoma. No entanto, cabe supor que esse lo seja uma forma neutra que poderia ser entendida como um isso no PB 
indispensável, apesar do grau genérico do constituinte retomado. Em consulta particular via e-mail, a professora Maite Celada atribui o uso do clítico ao caráter altamente determinado do constituinte retomado (embora com grande carga de genericidade). De acordo com as palavras de Celada:

Para mí está altamente determinado el sintagma, con una genericidad cargada, para decirlo de algún modo: "todos esos coches" ya los especifica como una clase y, después: "Los Lamborghinis, todos los Ferraris estos" (el estos retoma esa clasificación), por eso sería muy difícil pensar el meten sin el "los", sin el átono que los retoma. "Cuando meten en los circuitos..." imposible, nunca lo escucharía... creo. Se diría cuando entran en circuitos....

A interpretação de Celada corrobora o que viemos defendendo até aqui: da relação entre retomada por clítico de um constituinte com função de Orientação correferente a um Objeto determinado/especificado. Outro exemplo de nosso corpus é:

(25) *RAU: el depósito / yo te cuento un poco los elementos que [/] que lleva //\$ lleva / un cubeto de retención / por si acaso / este depósito / por cualquier / \&eh / motivo / [...] (CORAL-ROM- epubdl04)

[o depósito, eu te conto um pouco os elementos que leva]

[o depósito, eu te conto um pouco os elementos que ele leva]

Em (25) o constituinte el depósito ocupa Pre, tanto que vem seguido de uma barra indicadora de pausa e constitui a Orientação. Sintaticamente, esse termo seria o Sujeito da Oração subordinada à principal: Yo te cuento un poco los elementos que el depósito lleva. Por ser Sujeito, ele não é retomado na Oração, ou seja, não temos aqui a necessidade de duplicação por um pronome, como nos exemplos que apresentamos anteriormente, em que a Orientação era exercida por um constituinte que desempenharia a função de Objeto da Oração e era retomado por um clítico. Essa constatação é evidente, uma vez que os clíticos são pronomes oblíquos, com função sintática de Objeto do ponto de vista da tradição gramatical, e de Locativos, pela GDF.

É importante destacar que (25) foi a única ocorrência em nosso corpus de EP com um termo correferente ao Sujeito (este depósito) servindo como Orientação, mas que por se tratar de uma sentença subordinada, foge ao escopo desta pesquisa. Embora saibamos, a partir de exemplos como (21a) e (21b), dados por Gutiérrez Ordóñez, que podem existir na língua, não encontramos nenhuma ocorrência desse 
tipo de Orientação em sentenças simples em nosso corpus, muito ao contrário do que constatamos em PB, em que os constituintes colocados em Pre foram justamente os referentes aos Sujeitos.

Portanto, se pensamos nas ocorrências em PB, em que as Orientações são desempenhadas por constituintes que seriam Sujeitos, encontramos uma diferença entre as duas línguas: em PB, como vimos, essas Orientações correferentes a Sujeitos são retomadas na Oração, em forma de um pronome pessoal do caso reto (já que os pronomes oblíquos são mais usados em contextos formais e, embora sejam possíveis na língua, não ocorreram em nosso corpus), como vimos nos exemplos (3), (4), (6) e (9): o Tommaso $\rightarrow$ ele / os chuveiros $\rightarrow$ eles / meu vô $\rightarrow$ ele / essas pessoas $\rightarrow$ elas / Deus $\rightarrow$ ele. No EP, por outro lado, não houve nenhuma ocorrência desse tipo em nosso corpus, ou seja, nenhum constituinte com função de Orientação, correferente ao Sujeito da Oração, foi retomado na Oração por um pronome pessoal como él ou ella, por exemplo. Não obtivemos, desse modo, ocorrências como a que criamos a seguir:

(21b) ? La mujer que buscabas, creo que ella está en la tienda.

[a mulher que procuravas, acho que ela está na loja]

(22b) ? El hombre del paraguas, él tiene malas costumbres.

[o homem do guarda-chuva, ele tem maus costumes]

Assim, ainda sem pretensões de generalizar, mas apontando apenas o que os dados de nossos corpora nos revelaram, mas que teriam que ser investigados em outras variedades do PB e do EP, e com base também em estudos sobre o Parâmetro do Objeto Nulo em português, dos quais falaremos logo a seguir, corroboramos várias percepções que González (1994, 1998, 2000, 2005, 2008, 2014) e que outros pesquisadores vêm mostrando em suas pesquisas e que fomos retomando em várias seções deste trabalho. Aqui, adequamos algumas dessas constatações da pesquisadora aos conceitos da GDF e reinterpretamos alguns conceitos: 
(i) as Orientações correferentes aos Sujeitos das Orações não são retomadas lexical ou pronominalmente ${ }^{160}$ em EP, enquanto sim, são retomadas pronominalmente em PB. Ao contrário, as Orientações correferentes aos Objetos das Orações são sempre retomadas em forma de clítico no EP quando o Objeto é um Tópico (como vimos em 12, 14, 15, 20, 23 e 24: lo del teatro $\rightarrow$ lo / Lo de la puerta $\rightarrow$ lo / eso de la cocina $\rightarrow$ lo / estos conjuntos $\rightarrow$ lo / Caviar iraní $\rightarrow$ lo / los Lamborghinis / todos los Ferraris estos $\rightarrow$ los), e não retomadas quando o Objeto não é Tópico (como vimos em 11: Vino $\rightarrow \varnothing)$;

(ii) em PB, essas Orientações, quando correferentes o Objetos Tópicos, podem ou não ser retomadas explicitamente, dependendo do registro adotado, do gênero em que aparecem etc.. Em nosso corpus, os retomados por anáfora zero foram os exemplos (7) e (8): isso $\rightarrow$ é só soldar $\varnothing$ de novo / as pilhas $\rightarrow$ eu coloquei $\varnothing$ aqui), enquanto a única ocorrência retomada explicitamente foi a (5), com pronome forte: o projeto lá que o João fez ele podia assim finalizar ele.

Pensamos que, nos casos de Objetos Tópicos em PB, correferentes com a função de Orientação, há, portanto, uma maior oscilação/flexibilidade entre as retomadas pronominais ou por anáfora zero: parece-nos que (8) poderia ocorrer na língua com retomada explícita: as pilhas $\rightarrow$ eu coloquei elas aquileu as coloquei aqui, e que (5) poderia ocorrer com anáfora zero: o projeto lá que o João fez ele podia assim finalizar $\varnothing$.

Essa diferença do tipo de retomada dos constituintes correferentes aos Objetos nas duas línguas pode ser explicada pelo Parâmetro do Objeto Nulo em PB. Raposo (1998, 1999, apud KATO, 2011) mostra que o português é a única língua românica que admite resumptivo nulo. ${ }^{161}$ Para comprovar essa particularidade do

\footnotetext{
160 Falamos de retomadas lexicais e pronominais para diferenciá-las das anáforas zero, considerando que toda Orientação é pragmática e semanticamente dependente da Oração e que, se não é retomada de forma explícita (por um pronome ou pela repetição da palavra), é retomada por anáfora zero.

161 O termo resumptivo, usado por Kato (2011) corresponde ao que aqui estamos chamando de retomada ou anáfora lexical ou pronominal do termo correferente ao Objeto, com função de Orientação. O termo resumptivo nulo, portanto, corresponde à retomada desse constituinte por anáfora zero. Os casos que a autora chama de Objeto Nulo correspondem ao que, em nossa interpretação, baseada na GDF, seriam as retomadas ou não de Tópicos, como os pares trazidos por ela: a. eu só encontrei $\emptyset$ na FNAC / a' eu só o encontrei na FNAC / b. "sólo encontré Ø en la FNAC / b'. sólo lo encontré en la FNAC (KATO, 2011, p. 14).
} 
português, Kato (2011, p. 13) retoma alguns exemplos dados pelo autor e os compara com a língua espanhola, com os seguintes pares de sentenças (das quais, a marcada com asterisco é interpretada pela autora como agramatical):

(26a') esse livro, eu só o encontrei na FNAC

(26b) *ese libro, sólo encontré $\varnothing$ en la FNAC

(26b') ese libro, sólo lo encontré en la FNAC

A autora observa que os exemplos acima correspondem ao português formal e que, por isso, se usa o clítico 0 , mas que no português coloquial, no lugar desse clítico teríamos o pronome forte ele (que é o que ocorre em nossos exemplos, por se tratar de um corpus oral coloquial), em uma sentença como esse livro, eu só encontrei ele na FNAC.

As razões para os usos do resumptivo expresso ou do resumptivo nulo em PB são várias, segundo Kato (2011). A autora traz diversos exemplos e explicações ao comparar as variedades coloquiais do PB e do Português Europeu, e diz que o tipo de retomada (coindexação, nos termos usados pela autora, que segue uma abordagem gerativista de análise dos dados), seja explícita ou nula, depende de vários traços do Objeto, tais como [+animicidade], [-animicidade], [+humano], [humano], se se trata de nomes nus contáveis e incontáveis, etc. O que nos interessa, dados os propósitos deste trabalho, é observar que:

O PB vem sofrendo mudanças em sua realização pronominal: enquanto o sujeito referencial vem deixando de ser nulo, o objeto referencial, que era necessariamente um clítico até o século passado, passou a poder ser nulo ou um pronome forte (KATO, 2011, p. 19).

Constatação semelhante e em comparação entre o PB e o EP já havia sido feita por Alves-Silva (2009):

[...] pode-se dizer que o espanhol tende a explicitar o pronome em função de objeto e a omiti-lo em função de sujeito; por outro lado, o português brasileiro tende a explicitar o pronome para essa última categoria e a omiti-lo na função de objeto (ALVES-SILVA, 2009, p. 101). 
Vale destacar, porém, que muito antes dessas duas citações acima, mais precisamente em sua tese de doutorado defendida em 1994, González (que se baseou, entre muitos teóricos, nas reflexões que Kato já havia publicado naquela época) já havia percebido essas assimetrias entre o PB e o EP. O trecho que citamos a seguir é um pouco longo, mas condensa boa parte de suas conclusões, as quais corroboramos no presente trabalho. O termo deslocamento à esquerda, usado pela autora, pode aqui ser entendido como um constituinte que ocupe a primeira posição do enunciado, e que, de acordo com a GDF e com o que mostramos aqui, pode corresponder, nos casos que nos interessam, tanto aos Tópicos quanto às Orientações.

Conclui-se disso que espanhol e português brasileiro não diferem quanto a utilizar deslocamento à esquerda, como quer que se interprete esse deslocamento (por movimento ou por geração de base). Espanhol e português brasileiro diferem quanto à possibilidade de ter ou não uma categoria vazia pronominal no objeto, ou mais ainda, quanto aos contextos em que a lacuna pode ou não ser licenciada. A assimetria entre as duas línguas se configuraria, assim, em que o português brasileiro, carente de prossintagmas para certas categorias e com uma 'existência residual de clíticos nulos para argumentos', segundo Kato (1993b: 250), licencia as categorias vazias de complemento em um número maior de contextos e dá preferência a elas sobre outras formas possíveis. Enquanto isso, o espanhol não apenas teria um licenciamento muitíssimo mais reduzido das categorias vazias de complemento, mas daria preferência àquelas construções nas quais a duplicação clítica ocorre, mesmo quando não aceitas pela norma padrão (GONZÁLEZ, 1994, p. 271).

As conclusões de González (1994), de Alves-Silva (2009) e de Kato (2011), vêm ao encontro de nossa percepção baseada nas ocorrências em nossos corpora e que viemos explicando nesta seção e nas anteriores: parece que o PB tende a manter Sujeitos lexicais e Objetos nulos, enquanto o EP tende a manter Sujeitos nulos e Objetos lexicais. Em ambas as línguas, logicamente os constituintes lexicais é que podem funcionar como Orientação. Esse mesmo constituinte com função de Orientação poderá ser correferente ao Tópico da Oração. Assim, como o EP tende a manter Objetos expressos, são os constituintes correferentes aos Objetos que tendem a ser topicalizados e, consequentemente, a terem um constituinte correferencial como Orientação. O EP mantém, desse modo, a tendência que estamos defendendo aqui de não topicalização dos Sujeitos. Em sentido contrário, o PB tende a topicalizar os Sujeitos, mantendo-os como constituintes expressos e, portanto, sendo 
correferenciais a um constituinte com função de Orientação, não topicalizando, assim, os Objetos.

Esquematicamente, essas ideias podem ser representadas da seguinte maneira:

\begin{tabular}{|c|c|c|}
\hline \multicolumn{2}{|c|}{ ORIENTAÇÃO } \\
\hline Objeto & $\begin{array}{c}\varnothing \text { ou clítico (formal) ou } \\
\text { pronomes fortes (coloquial) }\end{array}$ & $\begin{array}{c}\text { Enáfora com clítico (formal e } \\
\text { informal) }\end{array}$ \\
\hline Sujeito & $\begin{array}{c}\text { anáfora } \\
\text { com pronomes fortes }\end{array}$ & $\varnothing$ \\
\hline
\end{tabular}

Esquema 31 - Tipos de anáforas nos Enunciados com Orientações

Um último recurso para a marcação da função retórica de Orientação usada no PB que queremos comentar muito rapidamente é a de colocar em Pre um constituinte que é um modificador Locação, como no exemplo seguinte:

(27) *ERN: é / geralmente os lugares que são assim / históricos / museus / igrejas / nũ deixam mesmo tirar //\$ (C-ORAL-BRASIL-bfamdl21)

O contexto de (27) são dois colegas conversando sobre a proibição de tirar fotos em locais históricos, como museus e igrejas. Ao invés, no entanto, de manter o termo locais históricos em $\mathrm{PF}$, a Falante preferiu marcá-lo como Orientação, apagando, para isso a preposição em. Não tivemos nenhuma ocorrência desse tipo em EP e, por isso, não podemos afirmar se essa possibilidade está ou não disponível nessa língua.

A seção a seguir aborda a segunda função retórica que nos interessa nesta pesquisa: o Esclarecimento. 


\subsection{Tão sendo muito legais, as aulas / Está perdiendo la audiencia ya, el programa: a função Esclarecimento}

A função Esclarecimento (Clarification) demonstra a intenção do Falante de acrescentar ou corrigir uma informação do Ato Discursivo nuclear que ele julgue importante para facilitar a compreensão do seu enunciado e, portanto, para que se tenha êxito no processo comunicativo. Corresponde ao que Dik (1989) denominava antitema, e outros chamam de antitópico. Autores como Mioto (2012) e Kato (1994, 1999), referem-se a essas estruturas como Afterthought (ou pensamento posterior / reconsideração), argumentando que se trata de constituintes com função de Sujeito que apareçam expressos no final da Expressão Linguística. Nós não partilhamos dessa interpretação, pois o Sujeito é um constituinte oracional, enquanto o Esclarecimento é extraoracional. No entanto, o Esclarecimento pode ser correferente ao Sujeito da Oração, seja por anáfora lexical ou pronominal, por um lado, ou zero, por outro (alocado na Oração). Vejamos um exemplo:

(27) *ELI: <ah / mas ele é muito> fechado / né / o <Vilson> // (C-ORAL-BRASILbpubdl08).

No exemplo (27), o Falante julga conveniente aclarar a quem está se referindo (ou seja, a quem se refere o pronome ele), já que no contexto apareciam os nomes de outros homens (Lincon, Paulo e Vilson), os quais eram o tema da conversa entre os Interlocutores. Assim, para evitar uma provável ambiguidade, a Falante prefere usar um recurso extraoracional. Pode-se dizer, então, que o Esclarecimento faz uma remissão anáfórica ao Ato nuclear, enquanto a Orientação, como vimos, uma remissão catafórica.

No Nível Interpessoal, portanto, o Movimento que abrange o Esclarecimento também contém dois Atos Discursivos, assim como ocorre na Orientação: um nuclear e um subsidiário, com llocuções próprias, o que também pode ser verificado na transcrição pelo uso da barra simples, indicando uma pausa prosódica que separa o último constituinte do restante da Expressão Linguística.

Além disso, junto com os Esclarecimentos, é bastante recorrente o uso de material lexical invariável, na maioria das vezes representados por Atos Interativos 
(como no nosso exemplo, o constituinte né), mas também muitas vezes demonstrando hesitação, pausa e repetições entre a Oração e o Esclarecimento.

Pelo fato de expressar um pensamento posterior, a posição icônica da função Esclarecimento é depois da enunciação do Ato Discursivo nuclear, na Ppos, como mostra o esquema:

\begin{tabular}{|c|c|}
\hline Pcentro & Ppos \\
\hline Oração & Esclarecimento \\
\hline
\end{tabular}

Esquema 32 - Esquema básico do Esclarecimento

Vejamos mais um exemplo de Esclarecimento em PB:

(28) *MAR: é \&m [/2] ahn / é \&mui [/2] tão sendo muito legais / <as aulas> // (C-ORALBRASIL-bpubdl08).

Analisando todo o Contexto do diálogo do qual extraímos o exemplo (28), o constituinte que ocupa o final da sentença não serve para desambiguar ou preencher uma possível lacuna na informação do Destinatário, já que o assunto é justamente as aulas de inglês (o coordenador da escola está perguntando a um dos alunos como estão sendo as aulas de inglês). Não há, no Contexto, nenhum outro constituinte a que se poderia referir o termo legais, o que mostra que a funcionalidade do Esclarecimento não é apenas o de desambiguar, mas também de retomar um Tópico que tenha ficado mais distante contextualmente. Além disso, o constituinte as aulas, que aparece como último elemento da Expressão Linguística, não tem nenhum correferente lexical ou pronominal na Oração, apenas a concordância verbal nos faz ver a correferencialidade entre estão e as aulas, diferentemente do que ocorre em (27), por exemplo, o que mostra que os Esclarecimentos não precisam necessariamente ser correferentes a um termo lexical da Oração, pois sua dependência é semântica, e não sintática.

Essa constatação é válida na comparação entre (27) e (28), cujos constituintes com função de Esclarecimento são correferentes aos Sujeitos das Orações. Não podemos afirmar categoricamente se é válida também aos correferentes a Objetos, pois não houve nenhuma ocorrência desse tipo em nosso 
corpus do PB. No entanto, supomos que sim e que não haja diferença de estruturação entre Esclarecimentos correferentes a Sujeitos ou a Objetos em PB. Suponhamos uma sentença como a seguinte:

Eu comi, o bolo.

A sentença (29) tem o termo o bolo em Ppos, por ser um Esclarecimento, correferente ao Objeto nulo da Oração. No entanto, seria perfeitamente possível usar um Objeto pronominal na Oração, sendo provavelmente um pronome forte em contextos coloquiais e pronomes oblíquos em formais, como vemos em (30) e (31):

(30) Eu comi ele, o bolo.

(31) Eu o comi, o bolo.

Podemos sistematizar as características dos Esclarecimentos da seguinte maneira: é um constituinte sintagmático ${ }^{162}$ extraoracional, que ocupa $P^{\text {pos }}$, sem função sintática na Oração, mas correferente, seja de maneira explícita ou por anáfora zero, a outro constituinte oracional, com funções desambiguadora ou aclaradora. É um Ato discursivo dependente, com sua própria llocução, e marcado por uma pausa ou mudança na tessitura. Todas as características se aplicam também ao EP, porém, da mesma maneira que no EP o uso de um clítico é imprescindível na retomada tanto de Tópicos como de Orientações expressos por constituintes definidos, a mesma restrição vale para os constituintes com função de Esclarecimento. Por isso, os exemplos de (29) a (31) do PB seriam traduzidos ao EP por Lo comí, el paste/la tarta/la tortal (o termo varia dependendo da variedade adotada). Vejamos, que, em EP, usase um clítico $(/ o / l a)$ em $\mathrm{P}^{\mathrm{I}}$ da Oração, com função pragmática de Tópico, porque o constituinte com função de Esclarecimento está determinado (el pastel/la tarta/torta).

Vejamos alguns exemplos de Esclarecimento que apareceram em nosso corpus:

\footnotetext{
${ }^{162} \mathrm{~A}$ restrição para que seja sintagmático deve-se à diferenciação entre essa função e a Aposição, que,
} segundo a GDF é composta por uma Oração relativa não restritiva. 
(32) ${ }^{*} E L E:[<]<y$ el perro> / que es gigante / no?\$ entonces / Ana / todo el tiempo protestando por el perro //\$

${ }^{*}$ CRI: o sea / encima no le molan los perros / claro //\$

${ }^{*} E L E:<h h h>/ / \$$

${ }^{*}$ CRI: $[<]<$ a Ana $>/ / \$$

${ }^{*} E L E$ : es que a ella Ana / no les dijo que no le molaran //\$ pero / el perro de Aitana / como es gigante / entonces y \&apa [/] y huele fatal ...\$ (C-ORAL-ROM-efamdl08)

[ou seja, além do mais não lhe agradam os cachorros, claro. [...] a Ana] [ou seja, além do mais ela não gosta de cachorros, claro. [...] a Ana]

Em (32), as Falantes conversam sobre a viagem que fizeram de carro, entre quatro pessoas, junto com o cachorro de uma delas (de Aitana). A presença do animal incomodou uma das passageiras (Ana), pois ela não gosta de cachorros (no le molan los perros $\rightarrow$ não the agradam os cachorros). Para esclarecer de qual das quatro pessoas presentes no carro se está falando, e à qual se refere o clítico do Ato Discursivo anterior (le), a Falante usa o constituinte a Ana, isolado como Ato Discursivo dependente desse anterior, servindo de Esclarecimento.

Em (33), a seguir, o Falante esclarece o referente do clítico lo do Ato Discursivo ¿tú lo conoces? (você o conhece?). O teatro já era tema da conversa, mas há vários turnos não era mencionado.

*OÑO: o sea que era hhh chiquitito chiquitito / no ?\$

*UEL: era muy chiquito //\$ \& mo \& + \$ tú lo conoces / el Teatro de la Abadía?\$

*OÑO: no //\$ no he estado nunca // \$ (C-ORAL-ROM-efamdl20)

[era muito pequenininho. Você o conhece? O teatro da Abadía?]

[era muito pequenininho. Você conhece (ele)? O teatro da Abadía?]

O último exemplo que trazemos é o (34):

(34) *PIE: / que está perdiendo audiencia ya [/] audiencia ya / <el programa $>/ /$ (CORAL-ROM-efamdl33)

[que está perdendo audiência já, o programa]

Um programa de televisão em especial (Tómbola) é o tema da conversa em (34). Provavelmente devido a esse Tópico (el programa) já estar um pouco distante contextualmente, a Falante prefere retomá-lo, alocando-o em Ppos. Aqui, não há nenhuma possibilidade do uso de um clítico na Oração, pois o termo esclarecido é correferente ao Sujeito da Oração, e não ao Objeto, como ocorre em (32) e (33). 
As duas ocorrências com função de Esclarecimento que encontramos em nosso corpus do PB estão em construções de identificação, ou seja, com EsCos [dinâmicos] e verbo ser e, por isso, não entram na delimitação de análise que propomos para este trabalho. Por entendermos que possam ser diferentes das categorias que escolhemos analisar, de Propriedades Configuracionais de predicado de 1, 2 e 3 lugares, de EsCos [+dinâmicos], parece-nos imprudente analisá-las comparativamente às ocorrências que encontramos em EP, embora tenhamos feito o exercício de imaginar sentenças como (30) e (31). Além dessas, podemos supor também sentenças como a (35), de EsCo [+dinâmico] e constituinte com função Esclarecimento correferente ao Sujeito da Oração:

Ela já foi embora, a professora. Já foi embora, a professora.

Em (35), o constituinte professora é correferente a ela, e em (35') é correferente a um Sujeito elíptico, o que nos mostra que, em PB, Esclarecimentos correferentes a Sujeitos podem ou não ter um lexema correspondente na Oração. Para observar como isso ocorre no EP, vejamos a tradução de (35):

? Ella ya se fue, la profesora.

Ya se fue, la profesora.

Vemos que (36) é duvidosa quanto à sua gramaticalidade/aceitabilidade na língua, enquanto (36') é a opção mais provável de ser realizada em EP. Isso se deve ao fato de (36) ter um pronome forte (ella) com função de Sujeito na Oração, correferente ao constituinte com função de Esclarecimento. Mais uma vez, e redundantemente, isso nos aponta para a não expressão dos Sujeitos pronominais em EP, ao contrário do que acontece em PB, e configura mais uma evidência de nossa tese sobre a não topicalização dos Sujeitos na língua espanhola.

Mesmo refletindo sobre esses exemplos, parece-nos que os dados obtidos sobre a função de Esclarecimento em nossos corpora foram muito poucos - apenas 2 em PB e 3 em EP - o que inviabiliza uma comparação confiável entre as duas línguas. Uma possibilidade, também, é de que não tenhamos percebido mais ocorrências dessa função pelo fato de não termos feito um estudo aprofundado da prosódia dos 
enunciados, apesar de termos acesso aos arquivos de áudio e o auxílio dos símbolos das barras usadas nas transcrições.

Mensurar se houve ou não uma pausa ou uma mudança de tessitura para a marcação dessa função exigiria uma análise prosódica minuciosa, com auxílio de softwares específicos para tal. Como o critério fonológico parece ser o único distintivo formalmente entre essa função e uma simples colocação de Tópico ou Foco em PF, configurando sentenças com ordens VOS ou OVS, por exemplo, assumimos que não dispusemos das ferramentas necessárias para uma análise criteriosa desses casos. Essa tarefa fica pendente, assim, para uma possível futura pesquisa.

Somos conscientes de que podemos ter corrido um risco semelhante nas análises dos constituintes com função de Orientação, que também dependem de fatores prosódicos. No entanto, parece-nos que a quantidade de ocorrências que conseguimos identificar de Orientações em nossos corpora foi suficiente para termos parâmetros para as comparações que fizemos.

O que registramos aqui sobre a função Esclarecimento, portanto, são vagas impressões, a partir somente das poucas ocorrências que obtivemos e dos exemplos que criamos: parece que não há grandes divergências quanto à configuração dessa função nas duas línguas analisadas. Quando esclarecem constituintes correferentes a Objetos, tanto o PB como o EP parecem poder licenciar retomadas lexicais ou nulas. Em PB, o mesmo ocorre com constituintes correferentes a Sujeitos, mas não sabemos afirmar se o EP tende a licenciar somente retomadas nulas para esses casos, como, intuitivamente apenas pensamos que possa ser.

Neste capítulo, tratamos sobre as duas funções retóricas que nos interessavam do ponto de vista da ordenação dos constituintes. Os exemplos dados desde o capítulo 3 até aqui, no entanto, foram, em sua maioria, de sentenças com llocução Declarativa, embora tenhamos passado brevemente por algumas questões relacionadas às Interrogativas. O último capítulo deste trabalho, a seguir, aborda especialmente essas llocuções. 


\section{CAPÍTULO 6}

\section{ILOCUÇÕES INTERROGATIVAS}

Um dos nossos objetivos neste trabalho é analisar a ordenação dos constituintes em sentenças Interrogativas dos tipos Polares (IPs) e de Conteúdo (ICs), passando rapidamente pelas Interrogativas Retóricas, e observando principalmente o posicionamento do constituinte $Q$ e do predicado e seus argumentos, além das respostas dadas às llocuções Polares. Para isso, dividimos este capítulo em uma primeira parte, na qual apresentamos os conceitos gerais e em outras duas grandes partes: as análises e comparações das IPs nas duas línguas e as análises e comparações das ICs nas duas línguas. Ao final, abrimos uma seção que retoma e revisita os objetivos e as hipóteses da pesquisa, como modo de caminharmos rumo às considerações finais deste trabalho.

\subsection{Conceitos gerais}

Devido ao escopo de nossa pesquisa, nos limitaremos a abordar as sentenças com llocução Interrogativas do tipo diretas (excluindo as indiretas), de dois tipos: (i) as Polares (polar Interrogative, doravante IP), que são chamadas pela tradição linguística de Interrogativas Fechadas ou do tipo $\operatorname{sim} /$ não, com suas respectivas respostas; e (ii) as Interrogativas de Conteúdo (content Interrogative, doravante IC), chamadas pela tradição linguística de Interrogativas Abertas ou do tipo $Q .{ }^{163}$ Excluiremos, portanto, ao menos neste momento, as Interrogativas Eco, entre outras, e passaremos rapidamente pelas Interrogativas Retóricas.

Nosso foco serão as diferentes ordenações dos constituintes nesse tipo de llocução (especialmente do constituinte Q e do Predicado e seus argumentos, ou seja, dos constituintes não hierárquicos), baseando-nos no alinhamento entre a codificação dessa estrutura nos níveis Morfossintático e Fonológico e suas formulações nos níveis Interpessoal e Representacional. Esse recorte deixa pendente um maior

${ }^{163}$ A nomenclatura em PB Interrogativas- $Q$ advém da nomenclatura em inglês Wh questions. 
aprofundamento em questões referentes à entonação e em outras abordagens não menos importantes deste tipo de construções.

Perini (2010) observa que Oração Interrogativa não é sinônimo de pergunta, pois nem sempre existe uma correlação entre elas, visto que frases afirmativas, com llocução Declarativa, também podem funcionar pragmaticamente como perguntas, como ocorre no exemplo que trazemos do próprio autor:

(1) Eu esqueci o seu nome. (PERINI, 2010, p. 123)

Além disso, pode-se também usar uma Interrogativa para expressar outros objetivos comunicativos, que não sejam perguntas, como acontece em (2), em que o efeito comunicativo é de ordem ou pedido:

(2) Você não consegue ficar calado não? (PERINI, 2010, p. 123)

Considerando, portanto, que não é apenas o tipo de llocução que determina se uma Oração é do tipo interrogativa, faz-se necessário analisar quais são as características desse tipo de Oração.

As IPs e as ICs se diferenciam pela entonação, pela estrutura sintática e pela semântica, que na verdade refletem diferenças pragmáticas, como veremos.

Segundo Perini (2010) e Castilho (2014), para expressar as IPs, é necessário acrescentar apenas um contorno entonacional ascendente à estrutura afirmativa, sem ter que recorrer a nenhum operador especial. Discursivamente, o Falante usa esse tipo de interrogativa quando quer "[...] apenas obter uma 'confirmação ou desconfirmação de um fato' [...]" (CASTILHO, 2014, p. 324).

Transpondo a ideia de Castilho (2014) à perspectiva da GDF, podemos dizer que no Nível Interpessoal, as llocuções Interrogativas como um todo servem para que - Falante requeira uma resposta do Ouvinte para preencher uma lacuna de informação existente em sua (do Falante) informação pragmática. Nas IPs, essa resposta se refere a todo o Conteúdo Comunicado, enquanto nas de ICs, se refere apenas a um Subato, como veremos mais adiante. Um exemplo de IP poderia ser Você entregou a tese? e um exemplo de IC poderia ser O que você fez?

Nas IPs, há um operador de EsCo de Polaridade. Nos sistemas de polaridade, geralmente apenas a polaridade negativa é marcada (com alguma partícula negativa), 
enquanto a positiva não é marcada. Os autores alertam que, além dessas polaridades extremas, positiva e negativa, pode haver ainda vários valores atribuídos à polaridade. Para exemplificar essa gradualidade, eles citam a expressão not yet (que poderíamos traduzir para o português por ainda não) e que pode ser interpretado como uma polaridade negativa antecipando um EsCo positivo.

Já as Interrogativas de Conteúdo (ICs) são Atos Comunicativos que têm sua llocução sobre apenas uma parte do conteúdo do Ato Discursivo, precisamente sobre um Subato Referencial. Desse modo, as ICs relacionam-se à identificabilidade do referente veiculado pelo Falante. Pezatti \& Fontes (2010, p. 187), baseando-se na GDF, fazem as seguintes considerações:

Em interrogativas- $Q$, o item interrogado é sempre marcado como $\{+i d$, -s\}, ou seja, identificado pelo Ouvinte, mas não especificado para o Falante. Assim, no Nível Interpessoal, o Subato Referencial (R), marcado $\{+i d,-s\}$, será expresso por meio de palavra-Q e entonação apropriada, sob a influência da llocução INTER.

De acordo com Mackenzie (2008a), as ICs codificam diferentes categorias semânticas, formando uma escala que vai de elementos mais concretos a mais abstratos: indivíduo $(\mathrm{x})>$ locação $(\mathrm{I})>$ tempo $(\mathrm{t})>$ modo $(\mathrm{m})>$ quantidade $(\mathrm{q})>$ razão (r). Assim, quando uma categoria é selecionada no Nível Representacional, uma palavra gramatical (ou operador) também é selecionada para expressar essa categoria no Nível Morfossintático. Em PB, selecionam-se os seguintes advérbios ou pronomes interrogativos, para as categorias abstratas acima: o que/que/quem (para $\mathrm{x})$, onde $(\mathrm{I})$, quando $(\mathrm{t})$, como $(\mathrm{m})$, quanto $(\mathrm{q})$ e por que/por quê $(\mathrm{r}){ }^{164} \mathrm{Em} \mathrm{E}$, respectivamente temos: qué/quién (para $\mathrm{x})$, dónde $(\mathrm{I})$, cuándo $(\mathrm{t})$, cómo $(\mathrm{m})$, cuánto (q) e por qué (r).

Segundo a GDF, nas ICs é possível valer-se de duas principais estratégias de expressão: a ordem dos constituintes e os padrões suprassegmentais. Como o foco do nosso trabalho é a ordenação, nos interessa observar o que desencadeia os diferentes posicionamentos do constituinte $\mathrm{Q}$ (em $\mathrm{P}^{\mathrm{I}}$, in situ, clivado ou em $\mathrm{P}^{\mathrm{F}}$ ) e seu arranjo com os demais constituintes não hierárquicos e aqueles com funções pragmáticas do Ato Discursivo.

164 Outras expressões como, entre outras, para quem (indicando Destinatário), para que (indicando finalidade), de quem (indicando posse), têm função semântica de Locativo, de acordo com a GDF. 
Já delimitados alguns conceitos, vamos então às análises nas duas línguas, começando pelas IPs.

\subsection{As Ilocuções Interrogativas Polares}

Constatamos que, em PB, é muito comum que as IPs venham acompanhadas da expressão né: assim, tudo o que foi enunciado antes de né deve ser interpretado como uma declaração e né funciona como um Ato Discursivo independente que ocupa Ppos e que poderia ser parafraseado por Não é verdade isso que eu disse?Nocê concorda com o que acabo de dizer? Tanto que a entonação de toda a frase pode ser declarativa e a llocução interrogativa recair apenas sobre o Ato Discursivo né.

(3) *PAU: cê sabe aqui como é que [/3] como é que tem que fazer esse muro aqui / né? (C-ORAL-BRASIL-bpubdl01)

(4) *ATA: fratura exposta / cê operou / né?

*JON: <operei> // (C-ORAL-BRASIL-bfamcv13)

Em nosso corpus do EP, percebemos que no caso de confirmação de hipótese, equivalendo ao né? do PB, é comum que essas llocuções terminem com expressões como, entre outras, ¿no?, ¿a que sí?, y ¿verdad?, ¿no es cierto?, sendo ¿no? a mais frequente. Vejamos os exemplos:

(05) *LOL: Pero sabes lo que significa ratón, ¿verdad?

*PIL: Sí, es lo que aprendí. (C-ORAL-ROM-efamdl01)

[ - Mas $\varnothing$ sabe o que significa mouse, verdade?

- Sim, é o que $\varnothing$ aprendi]

[ - Mas você sabe o que significa mouse, né?

- Sim, é o que eu aprendi]

(06) *MAN: Ahora bien, tú tienes una cocina un poco más alargada, ¿no?

*NIE: No, te queda igual, porque pasas ... (C-ORAL-ROMefamdl19)

[ - Pois bem, você tem uma cozinha um pouco mais alongada, não?

- Não, $\varnothing$ fica igual, porque $\varnothing$ passa ...]

[ - Pois bem, você tem uma cozinha um pouco mais alongada, né?

- Não, Ø/ela fica igual, porque você passa ...] 
*PRI: [...] pero es como extraterrestre. Tiene cara de extraterrestre, ¿a qué sí? *NUR: Es feíta (C-ORAL-ROM-efamcv07)

[ - mas é como extraterrestre. Tem cara de extraterrestre, não é verdade?

- É feinha]

Essas expressões equivalem na maioria das vezes à expressão né, como vimos nas análises do PB e nas traduções do EP ao PB, e servem para que tudo o que foi enunciado anteriormente seja interpretado como uma declaração afirmativa. Em E, na linguagem escrita (que não é o caso dos nossos exemplos, já que nossos dados são de fala transcrita com uso de sinais de pontuação que não seguem exatamente as normas da escrita), essa característica fica mais evidente que em PB, visto que os sinais de pontuação indicativos de interrogação aparecem também antes dessas expressões.

Vale ressaltar que, aqui, que os sí/no que aparecem nas respostas de (05) e (06) ocupam posições iniciais ou finais da expressão linguística, e não da Oração. Por isso, não falamos em $\mathrm{P}^{\mathrm{l}}$ ou $\mathrm{P}^{\mathrm{F}}$, que seriam as posições de sí/no ou $\operatorname{sim} /$ não caso eles funcionassem apenas como operadores semânticos de EsCos, estando próximos dos elementos escopados, como em Eles não entenderam nada, por exemplo, em que o operador de polaridade negativa ocupa $\mathrm{P}^{\mathrm{I}+1}$. No entanto, entendemos, junto com Gasparini-Bastos (2004, 2005, 2008), que, como respostas a perguntas, como ocorre em (05) e (06), sí/no e sim/não são Atos Discursivos independentes, que carregam a função de Foco e por isso, devem ser analisados no nível sintagmático. Segunda a pesquisadora, eles representam a intenção do Falante de expressar sua discordância ou sua concordância em relação ao Ato Discursivo precedente (de llocução Interrogativa). Desse modo, sim/não, como respostas, são formas de polaridade positiva e negativa, que desempenham função de Foco, embora também possam marcar Ênfase e Contraste. ${ }^{165}$ Ainda segundo a pesquisadora:

Verificamos que tanto as construções de polaridade positiva, como as construções de polaridade negativa são típicas de posição inicial, exercendo predominantemente a função de resposta do entrevistado ao entrevistador. Quando ocupam posições parentéticas ou finais,

${ }^{165} \mathrm{Na}$ verdade, Gasparini-Bastos (2008) fala de foco novo, foco enfático e foco contrastivo, pois se baseia no funcionalismo de Dik (1997) e nas ideias iniciais da GDF. O que estamos fazendo é uma releitura dos dados obtidos pela pesquisadora a partir de reconsiderações da GDF posteriores a 2008, já que, nas suas reformulações, a GDF passa a diferenciar, como já apontamos, Foco, Ênfase e Contraste. 
como reforço do que foi dito, tais construções tendem a denotar um grau maior de certeza, indicando um maior comprometimento do falante com seu enunciado. (GASPARINI-BASTOS, 2005, p. 443)

Concordamos com Gasparini-Bastos no que se refere ao efeito da presença inicial de sim/não nessas construções em PB e do efeito de reforço que tem sua retomada no final. É o que ocorre nos exemplos a seguir:

(08a) *GIL: uai / mas nũ ia ter o lance do quarto?

*VER: vai ter o quarto pra ele sim // (C-Oral-BRASIL-bfamcv12)

(09a) *PRI: passou tipo no cinema / Belas Artes / essas coisas assim?

*BRU: não / eu vi lá no Rio //

*PRI: <ah / tá> //

${ }^{*} B R U$ : <mas passou aqui / sim> // (C-Oral-BRASIL-bfamcv22)

(10a) *MAR: <eu tô> meio preocupado / porque ficar / preto e branco / vai +

${ }^{*} F A B$ : fica muito confuso / né?

*MAR: é / eu / acho que vai ficar meio claro assim / né // \&he / no final vai \&f [/1] tar o traço / ficar muito isso / né / vai ficar confuso sim / muito cinza / né // a nũ ser que se faça o [/1] o fundo bem / <mais escuro> // (C-Oral-BRASIL-bpubdl09)

Vemos que em (08a), (09a) e (10a) os sim ocupam posições nos finais das expressões linguísticas das quais fazem parte, porém não são Atos Discursivos independentes, mas sim operadores que se posicionan no mesmo domínio do elemento que escopam (PF). Acreditamos, junto com Gasparini-Bastos (2005), que esse posicionamento indica a marcação de Ênfase, diferentemente de sim em posição inicial do Enunciado, que indica Foco e deve ser analisado como Ato Discursivo independente, como vimos acima. Mais adiante, falaremos dos operadores de polaridade negativa.

Encontramos aqui uma diferença entre o PB e o EP (ao menos no âmbito do corpus analisado), já que, em nossos dados do EP, não houve nenhuma ocorrência de sí em $\mathrm{PF}^{\mathrm{F}}$ em sentenças simples. Em EP, quando o sí aparece em $\mathrm{PF}$, sempre ocorre em sentenças complexas (subordinadas ou coordenadas e que, portanto, fogem ao escopo deste trabalho) com expressões como te digo que sí, creo que sí, claro que sí, la verdad es que sí, ou precedidas de um marcador temporal como de vez en cuando sí, a veces sí. Se, portanto, tentássemos propor uma tradução literal das respostas desses exemplos (08a), (09a) e (10a) para o EP, parece-nos que teríamos uma construção talvez pouco típica (ou agramatical?), o que não podemos, no entanto, 
afirmar categoricamente sem antes fazer novas pesquisas, inclusive de aceitabilidade por parte de falantes nativos:

(08b) (?) Va a tener la habitación para él sí.

(09b) (?) pero pasó por aquí sí.

(10b) (?) va a quedar confuso sí.

A forma enfática em EP, que talvez correspondesse à funcionalidade do sim ocupando PF em PB, poderia ser representada por construções como (Pues) Sí que va tener... I Sí que pasó por aquí.../ Sí que va a quedar confuso. Ou seja, temos outra vez a presença do que como operador de Ênfase, como vimos no capítulo 4 (subitem 4.4). Não se trata, portanto, para a resposta enfática em EP, de uma questão de ordenação. É o que ocorre em (11):

(11) * [...] es que ya tu madre no se acuerda del médico / está hablando de el del / pueblo / me estoy acordando //\$ porque tú no te acuerdas del que había aquí en Valdemoro? //\$

${ }^{*} P A L$ : sí que me acuerdo //\$ sí //\$ (C-ORAL-ROM-efamcv02)

[sim $\varnothing(\mathrm{me})$ lembro. Sim]

No exemplo acima, além da repetição do sí (um em $\mathrm{P}^{\mathrm{I}}$ do enunciado e outro como Ato Discursivo independente, em $\mathrm{P}^{\mathrm{pos}}$ ), o que, servindo como operador enfático, permite que se subentenda algo como Ya te dije que sí. O Falante refuta, assim, uma dúvida implícita ou explícita do seu interlocutor.

Além disso, para marcar Ênfase de polaridade positiva, o E se vale de outras estratégias, tais como a repetição do sí (essa mesma estratégia, como vimos, também é usada em PB), como ocorre em (12) ou do uso de expressões que equivaleriam a um claro que sí/por supuesto, como jJoder! em (13):

*DOL: la persona con la que yo me tengo que entender / es <usted>?\$

*SEV: [<] <sí> sí <sí> //\$. (C-ORAL-ROM-epubdl07)

[ - A pessoa com a qual eu tenho que me entender é o senhor?

- Sim, sim, sim]

(13) *PAC: viste la perrilla de la abuela?\$

*PAT: <ijoder! //\$ qué loba> //\$ (C-ORAL-ROM-efamcv05) 
[- (você) viu a cachorrinha da avó?

- Caramba! Que loba!]

No entanto, conforme Perini (2010), Castilho (2014), Urbano et al. (1993), e conforme constatamos em nosso corpus, em PB, as respostas de polaridade afirmativa mais típicas para as IPs não fazem uso de sim. Muitas vezes, a preferência do Falante é usar a estratégia de repetição do verbo presente na pergunta, apenas com a atualização da desinência de pessoa. No nosso corpus, por exemplo, não tivemos nenhuma ocorrência de resposta afirmativa que usasse apenas a palavra sim. ${ }^{166}$ Constatamos que, no lugar desse operador de polaridade positiva, os Falantes preferiram ou repetir o verbo usado na pergunta, atualizando, quando necessário, apenas a desinência pessoal, como ocorre nos exemplos (14) a (17), ou recorrer ainda a um marcador de assentimento (uhn uhn), como vemos em (18):

(14) *JAN: cê [/1] cê tem aquele também / que dois gays / querem ter um filho? <não *BRU: <"Baby Love">?

*JAN: isso // cê tem?

${ }^{*} B R U$ : tenho // (C-ORAL-BRASIL-bfamcv22)

${ }^{*} P R I:<$ <á contou>? <pronto>?

${ }^{*} B R U:<$ contei> // (C-ORAL-BRASIL-bfamcv22)

(16) *CAR: chuveiro vai voltar a funcionar lá em cima?

*VER: ah / vai //

${ }^{*}$ GIL: <vai> // (C-ORAL-BRASIL-bfamcv12)

${ }^{*} A T A:$ bebe +?

*JON: ahn //

${ }^{*} M N V:<$ bebe $>/ /$

*ATA: <e e'> trabalha lá ainda / naquele pé do /1 do morro ali ?

*MNV: trabalha //

*ATA: ahn // (C-ORAL-BRASIL-bfamcv13)

(18) *MAR: tem que pagar pa entrar também?

${ }^{*} E R N$ : uhn / <uhn / aonde> que cê nũ paga pa entrar em Roma hhh //\$ - (C-ORALBRASIL-bfamdl21)

\footnotetext{
${ }^{166}$ Cabe reforçar, como já afirmamos no início deste trabalho, que o que descrevemos, para ambas as línguas, é o encontrado nos corpora utilizados para análise, nas respectivas variedades e variantes, o que implica que apontamos claras tendências para ambas, mas sem pretensão de generalizar as descrições, já que sempre é possível que em outras situações de produção, escrita ou oral, outros gêneros discursivos/textuais e em outras variedades e variantes não presentes nessas amostras outros fatos possam ser registrados.
} 
O Falante pode, ainda, optar por explicar sua resposta, que deve ser interpretada como sim/não implícitos, como em (19), em que subentendemos uma polaridade positiva na resposta dada: ${ }^{167}$

(19) *BEL: cê nunca pensou em / em [/1] em [/1] tipo assim / junto com [/1] com lingüística e tal / mexer com isso / assim / dando aula mesmo / e tal?

*BAL: ô / é uma coisa que já [/1] já [/1] de [/1] de vez em quando passa pela minha cabeça // (C-ORAL-BRASIL-bfamdI02)

Assim, nas respostas para as IPs em PB encontradas em nosso corpus não obtivemos nenhuma resposta afirmativa formada apenas por sim. Essa foi uma diferença bastante marcante entre as duas línguas, já que em EP, ao menos no nosso corpus, não houve nenhuma ocorrência de resposta constituída unicamente pela repetição do verbo da pergunta (respostas elípticas). O que queremos destacar, para os propósitos de nosso trabalho, é que, em PB, existe, "[...] no caso de Pergunta sim/não, uma preferência pelas Respostas elípticas, geralmente com verbo da Pergunta no lugar do sim, o que não acontece em outras línguas [...]" (URBANO et al., 1993, p. 77).

Ao contrário, em EP a resposta mais típica foi o uso de sí em $\mathrm{P}^{\mathrm{I}}$, seguido ou não de outro Ato Discursivo (algo que explicasse ou adicionasse alguma informação que o Falante julgasse relevante). A única ocorrência em que o verbo foi repetido apareceu antecedido por sí e seguido de seu complemento (la pena) como mostramos em (20a):

(20a) *UEL: $y$ / mereció la pena?\$ <hhh perderse el partido> ?\$ \%act: (5) laugh *OÑO: [<] <hhh perderse el partido>?\$ qué cabrón $/ / \$$ hhh $/ / \$$ sí $/ / \$$ sí mereció la pena $/ / \$$ (C-ORAL-ROM-efamdl20)

[- E valeu a pena? Perder o jogo/a partida de futebol?

- Perder a partida? Que sacana! Sim. Sim, valeu a pena]

Desse modo, não ocorreu nenhum caso como o que mostramos abaixo, uma simulação nossa, mantendo a forma de resposta mais típica do PB, o que nos leva a questionar se essa forma seria agramatical ou pouco usual em EP, ou ainda se ocorreria em outras variedades da língua e/ou em outros textos/contextos:

167 Neste trabalho, não analisaremos esse tipo de resposta. 
(20b) (?)- ¿Y mereció la pena? ¿Perderse el partido?

(?)- Perderse el partido, qué cabrón. Mereció $\varnothing$.

Vejamos alguns exemplos do tipo de resposta mais típico em EP, com base em nosso corpus (além das que já comentamos anteriormente):

(21) *MAR: el primero que había en Valdemoro cuando tu padre y yo vinimos a vivir / está en la misma calle / un poco más abajo / donde está la residencia de la tercera edad?\$ ésa que han agrandado [/] esa puerta que agrandan por el lateral ?\$ sabes que puerta te digo?\$ *PAL: sí //\$ (C-ORAL-ROM-efamcv02)

[sim]

(22) $\quad$ *CRI: [<] <ibais> con el perro de Aitana / también / no?\$

${ }^{*} E L E:$ sí //\$ hhh //\$ pero porque iba / Ricardo / después de toda la historia ésta que te conté / entonces $/ \$$ (C-ORAL-ROM-efamdl08)

[ - $\varnothing$ iam com o cachorro da Aitana também, não?

- Sim, mas porque ia Ricardo, depois de toda a história esta que te contei]

[ - Vocês iam com o cachorro da Aitana também, né?

- Sim, mas porque o Ricardo ia, depois de toda aquela história que te contei]

*UEL: pues / la verdad es que casi me quedé dormido //\$ $<y>+\$$

*OÑO: $[<]<h h h>/ / \$$ en tu línea / no ?\$ \%act: (1) laugh

*UEL: sí //\$ y encima luego / la silla estaba estropeada / así que / estuve poniendo posturitas durante / dos horas y cuarto //\$ o sea / muy incómodo //\$ (C-ORALROM-efamdl20)

[sim, e além disso logo a cadeira estaba quebrada, portanto estive pondo posturinhas durante duas horas e quinze minutos, ou seja, muito incômodo]

[sim, e além disso $\varnothing$ a cadeira estaba quebrada, por isso tive que ficar tentando me ajeitar durante duas horas e quinze minutos, ou seja, muito incômodo]

As respostas de (21), (22) e (23) nos indicam que em EP evita-se o uso de respostas constituídas apenas pelo verbo da pergunta. O exemplo (22) nos remete a outro fator importante que vimos no capítulo 4: a relação da pressuposição do Falante em relação à resposta esperada com a ordenação dos constituintes das IPs. Nossa hipótese é a de que, em $\mathrm{PB}$, o Falante coloca em $\mathrm{P}^{\mathrm{I}}$ um constituinte que normalmente não ocuparia essa posição, como o Objeto fratura exposta, no exemplo (24), para indicar que é esse constituinte que corresponde à informação que ele pressupõe como a correta, e que tem a função pragmática, portanto, do que denominamos Foco 
Pressuposto, ${ }^{168}$ já que indica a informação nova mais relevante (e esperada), mas que ainda precisa ser confirmada (no nosso exemplo a seguir, fratura exposta cê operou). Vimos que essa pressuposição, muitas vezes, é reforçada pelo constituinte né. Retomamos aqui o exemplo (87) do capítulo 4, agora reproduzido como (24):

${ }^{*} A T A$ : fratura exposta /cê operou, né?

* JON: operei (C-ORAL-BRASIL-bfamcv13)

Não encontramos nenhuma ocorrência desse tipo de ordenação das IPs em $\mathrm{EP}$, ou seja, nenhuma ocorrência de um Objeto ocupando $\mathrm{PI}^{\mathrm{I}}$ com função de Foco pressuposto. Ao menos em nosso corpus, o único recurso para indicar pressuposição foi alocar o operador de EsCo de Polaridade negativa ¿no? em PF da pergunta (equivalendo ao né ou a um próprio não em $\mathrm{PB}$ ), para indicar sua pressuposição sobre o Ato Discursivo imediatamente anterior, sendo todo o Ato Discursivo anterior um Foco Pressuposto, como pudemos ver no exemplo (22). Mas, na resposta, PB e EP diferem totalmente, como vimos, porque em $\mathrm{PB}$, no caso de resposta afirmativa, com mais frequência apenas reiteramos o verbo (operei) e ainda poderíamos enfatizá-lo com um sim posposto (operei sim).

Nas respostas negativas do PB, a variedade dialetal dos Falantes pode determinar se o não aparecerá anteposto ou posposto ao verbo. Na variedade paulista, por exemplo, pareceria haver um uso mais frequente de anteposição do não ao verbo, enquanto na variedade mineira, que analisamos em nosso corpus, é bastante frequente a posposição ou o uso de um não duplo (um átono, anteposto, e um tônico, posposto), como mostramos a seguir:

(25) *ATA: ô / mas nũ deu / infecção não? no lugar não? deu não? que bom / ué // $<$ menos mal / né> / Mané //

*JON: <deu não> // (C-ORAL-BRASIL-bfamcv13)

${ }^{*} R U T:$ cê pensa que ele / participa da [/1] \&d [/1] desses presente?

${ }^{*} T E R$ : é //

${ }^{*} R U T$ : participa não / minha filha // então tem que ser eu mesma // (C-ORALBRASIL-bfamcv02)

*RUT: [1] e a Dani / já escolheu os padrim do casamento?

*TER: [2] não // [3] ainda não // [4] inda <nada> // (C-ORAL-BRASIL-bfamcv02)

168 Sabemos que a GDF não contempla essa nomenclatura, mas parece-nos que é pertinente para o caso das IPs. 
Sem pretensões de generalizar, já que não fizemos uma investigação mais aprofundada sobre esse tema, mas, muitas das ocorrências de posposição do operador não que apareceram em nosso corpus parecem indicar que esse recurso é usado para marcar uma função pragmática de Contraste, diferente de um uso puramente declarativo, em que tal operador tende a aparecer em posição pré-verbal.

Em EP, não tivemos nenhuma ocorrência desse tipo para respostas de polaridade negativa, portanto, valeria a pena estudar se em outras variedades e registros do EP ou em outros tipos de textos/contextos, seria possível a existência de estruturas como as que criamos a seguir, como traduções literais dos nossos exemplos (25) e (26) do PB.

(28) (?) - pero, ¿no dio infección no? ¿En el lugar no? ¿Dio no? ¿Qué bueno, pues, menos malo, ¿sí, Mané?

- Dio no.

(?) - ¿Tú piensas que él participa de esos regalo?

- Sí.

- Participa no, mi hija, entonces tiene que ser yo misma.

Concluímos, assim, que em EP, diferentemente do que ocorre em PB, o Ato Discursivo no parece não ocorrer em $\mathrm{PF}^{\mathrm{F}}$ das respostas, ficando restrito à $\mathrm{P}$, sendo ou não duplicado (sem a diferenciação de uma forma átona e uma tônica para o operador negativo, diferentemente do que ocorre em PB, que dispõe de nũ e não) e funcionando sempre como Foco, como mostramos nos seguintes exemplos:

(30) *PIL: / y vas corriendo todo el día / andas corriendo de clase //\$ y de teatro [/] lo del teatro / lo has dejado <mucho>?\$

*LOL: <hhh / no> //\$ todavía me queda / uno \&añ [/] un año //\$ este año //\$ [...] (C-ORAL-ROM-efamdl01)

[Não, ainda me falta un ano. Este ano]

*UEL: era muy chiquito //\$ \&mo \& + \$ tú lo conoces / el Teatro de la Abadía?\$

*OÑO: no //\$ no he estado nunca // \$ (C-ORAL-ROM-efamdI20)

[Não. Não estive nunca]

*UEL: $[<]<$ no entrabas cansado>?\$

*OÑO: no //\$ (C-ORAL-ROM-efamdl20)

[Não.] 
Sobre a maneira de organizar as IPs, em PB é possível formulá-las com um constituinte com função de Orientação em Pre, que mostra sobre o que versará a pergunta feita na sequência, como mostramos a seguir:

*WOA: ai // então esses + cê importa / se eu provar? (C-ORAL-BRASIL-bpubdl02)

(35) *LUC: hum hum // e em relação às [/1] às atividades / que ela leva pra sala de aula / cê acha que mudou? (C-ORAL-BRASIL-bpubdl11)

(36) *LUC: \&he / então // em relação ao projeto de cartas / cê participou do projeto de cartas / nũ foi? escrita de cartas pro <projeto>? (C-ORAL-BRASIL-bpubdl11)

Em (34) o constituinte esses refere-se aos modelos de sandálias que a cliente está provando em uma loja. Trata-se, portanto, de um dêitico cujo referente era identificável pelo contexto situacional. Tanto em (34) como em (35), os constituintes com função de Orientação, marcados nos exemplos em negrito, são retomados nas IPs por anáfora zero. ${ }^{169} \mathrm{Em}(36)$, o referente do constituinte da Orientação é retomado lexicalmente na pergunta (o projeto de cartas).

Em EP as IPs também podem ter essa mesma organização: constituinte com função de Orientação em Pre, como mostramos abaixo em um exemplo que retomamos do capítulo 5, onde já lhe propusemos uma tradução:

(37) *PIL: / y vas corriendo todo el día / andas corriendo de clase //\$ y de teatro [/] lo del teatro / lo has dejado <mucho>?\$ (C-ORAL-ROM-efamdl01)

Como podemos observar, em (37), os constituintes y de teatro y lo del teatro ocupam $\mathrm{P}^{\text {pre }}$ e $\mathrm{P}^{\text {pre +1 }}$, aparecendo separados do restante do enunciado por uma pausa e marcando a Orientação do Ato Discursivo seguinte, ou seja, apontando para o assunto sobre o qual se interrogará. Como vimos antes, quando abordamos as llocuções Declarativas, aqui nas IPs também se usa a estrutura lo + de para a marcação de Orientação. Na sequência, o clítico lo ocupa $\mathrm{P}^{\mathrm{I}}$ da Oração, funcionando como o Tópico. Notamos que, com essa estrutura de ordenação, não há Foco nem informação pressuposta, como nos casos que apontamos anteriormente. O ponto

169 Como falante nativos, sabemos que é perfeitamente possível a retomada do constituinte com função de Orientação por um clítico tônico ocupando $\mathrm{PF}^{\mathrm{F}}$, em algo como EP a música, você escutou ela?, porém esse tipo de estrutura não ocorreu no nosso corpus, em se tratando das IPs. 
principal de divergência aqui entre o PB e o EP é, que, como já vimos, enquanto o PB prefere usar anáfora zero na Oração, deixando vazias as posições que seriam ocupadas pelos Objetos, o EP sempre usa uma anáfora com clítico para preencher a posição da Objeto na Oração. Portanto, o padrão das expressões com Orientação das duas línguas se mantém tanto em sentenças de llocução Declarativa, como demonstramos no capítulo anterior, quanto para as IPs. Além disso, como comentamos no capítulo 5 , a expressão $10+d e$, em EP, é um recurso para indicar Orientação e equivale a expressões em PB como em relação a, sobre (tal coisa), etc., tal como ocorre nos exemplos (35) e (36). Esse recurso, portanto, como acabamos de mostrar, também não é restrito às llocuções Declarativas.

Um último item que gostaríamos de comentar nesta seção é o posicionamento e o tipo do constituinte com função sintática de Sujeito nas IPs em EP. Observamos que não há diferenças quanto aos Sujeitos das llocuções Declarativas, ou seja, nas IPs o Falante também prefere usar um Sujeito Nulo (como ocorre nos exemplos 5, 7, $13,20,21,23,30,32$ e 37). Quando há a ocorrência de um Sujeito explícito, ele geralmente ocupa $\mathrm{P}^{\mathrm{l}}$, com a função de Tópico Contrastivo, como vemos nos exemplos 11, 12 e 31. Em (11) - es que ya tu madre no se acuerda del médico / está hablando de el del / pueblo / me estoy acordando //\$ porque tú no te acuerdas del que había aquí en Valdemoro - interpreta-se claramente o valor contrastivo do uso dos Sujeitos explícitos, já que o termo tu madre (aqui funcionando como um eu, já que se refere à própria Falante) se contrapõe a tú, expressando que uma não se lembra do médico, enquanto a outra, sim.

A seguir, apresentamos um quadro de síntese deste subcapítulo. Destacamos de verde as partes mais relacionadas aos nossos objetivos e hipóteses de pesquisa e que são específicas das llocuções Interrogativas. Outras partes, também relevantes para nossos propósitos, não estão aí destacadas por apresentarem resultados iguais aos que já constatamos nas llocuções Declarativas, como é o caso do funcionamento da função Orientação. As letras $A$ remetem a Ato Discursivo. Os exemplos marcados por * (?) são adaptações/traduções literais que fizemos, justamente para mostrar que a estrutura mais típica em uma língua tem sua gramaticalidade questionada na outra. 


\section{IPs - SÍNTESE COMPARATIVA}

\begin{tabular}{|c|c|c|c|}
\hline \multicolumn{2}{|r|}{ PB } & \multicolumn{2}{|r|}{ EP } \\
\hline PERGUNTA & Exemplo & PERGUNTA & Exemplo \\
\hline $\begin{array}{l}\text { Constituintes né /não } \\
\text { em Pos = Foco } \\
\text { pressuposto }\end{array}$ & $\begin{array}{l}\text { fratura exposta cê } \\
\text { operou né? }\end{array}$ & $\begin{array}{l}\text { Constituintes ¿no? / } \\
\text { ¿a que sí? / } \\
\text { ¿verdad? em Ppos = } \\
\text { Foco pressuposto }\end{array}$ & $\begin{array}{l}\text { Ahora bien, tú } \\
\text { tienes una cocina un } \\
\text { poco más alargada, } \\
\text { ¿no? }\end{array}$ \\
\hline $\begin{array}{l}\text { Tipo de Suj. } \\
\text { preferido: explícito, } \\
\text { independentemente } \\
\text { da posição. }\end{array}$ & $\begin{array}{l}\text { fratura exposta cê } \\
\text { operou né? } \\
\text { cê pensa que ele } \\
\text { participa desses } \\
\text { presente? } \\
\text { E e' trabalha lá } \\
\text { ainda?170 }\end{array}$ & $\begin{array}{l}\text { Tipo de Sujeito } \\
\text { preferido: nulo. } \\
\text { Quando há Suj. } \\
\text { explícito = Contraste } \\
\text { ou genérico }\end{array}$ & $\begin{array}{l}\varnothing \text { Ibais con el perro } \\
\text { de Aitana, ¿no? } \\
\text { Es que ya tu madre } \\
\text { no se acuerda del } \\
\text { médico[...] porque } \\
\text { ¿tú no te acuerdas } \\
\text { del que había aquí } \\
\text { en Valdemoro? }\end{array}$ \\
\hline $\begin{array}{l}\text { Objeto em } \mathrm{Pl}^{\mathrm{I}}=\text { Foco } \\
\text { Pressuposto }\end{array}$ & $\begin{array}{l}\text { fratura exposta cê } \\
\text { operou né? }\end{array}$ & ---- & ----- \\
\hline $\begin{array}{l}\text { Objeto em Pre } \\
\text { (Orientação) = } \\
\text { retomado na Oração } \\
\text { preferencialmente } \\
\text { por } \varnothing, \text { mas também } \\
\text { por repetição e por } \\
\text { pronome forte. } \\
\text { Suj. sempre } \\
\text { expresso }\end{array}$ & $\begin{array}{l}\text { E em relação às } \\
\text { atividades que ela } \\
\text { leva pra sala de } \\
\text { aula, cê acha que } \\
\text { mudou Ø? } \\
\text { Em relação ao } \\
\text { projeto de cartas, } \\
\text { cê participou do } \\
\text { projeto de cartas } \\
\text { nũ foi? } \\
\text { E a música, você } \\
\text { escutou ela? }\end{array}$ & $\begin{array}{l}\text { Objeto em Ppre } \\
\text { (Orientação) = } \\
\text { retomado na Oração } \\
\text { por clítico quando } \\
\text { [+específico] }\end{array}$ & $\begin{array}{l}\text { Y de teatro, ¿lo has } \\
\text { dejado mucho? }\end{array}$ \\
\hline $\begin{array}{l}\text { Suj. em Pre }=\varnothing \text { ou } \\
\text { pronome forte }\end{array}$ & $\begin{array}{l}\text { e a Dani, (ela) já } \\
\text { escolheu os padrim } \\
\text { do casamento? }\end{array}$ & Suj. em $\mathrm{P}^{\mathrm{pre}}=\varnothing$ & $\begin{array}{l}\text { el depósito ¿yo te } \\
\text { cuento un poco los } \\
\text { elementos que } \varnothing \\
\text { lleva? }{ }^{171}\end{array}$ \\
\hline
\end{tabular}

$170 e^{\prime}=$ ele

171 Como não tivemos nenhuma ocorrência de constituinte correferente ao Sujeito na Pre das IPs (assim como praticamente não tivemos nas Declarativas), adaptamos o exemplo (25) da seção sobre 


\begin{tabular}{|c|c|c|c|}
\hline $\begin{array}{l}\text { sim/não em Pre }=\mathrm{A} \\
\text { indepent. = Foco }\end{array}$ & $\begin{array}{l}\text { - Você sabe dirigir? } \\
\text { - Sim, sei. }\end{array}$ & $\begin{array}{l}\text { sim/não em Ppre }=\mathrm{A} \\
\text { indepent. = Foco }\end{array}$ & $\begin{array}{l}\text { No, te queda igual, } \\
\text { porque pasas ... }\end{array}$ \\
\hline \multirow[t]{2}{*}{$\begin{array}{l}\text { sim/não em } \mathrm{PF}=\mathrm{A} \\
\text { depen. = operador } \\
\text { de Ênfase. }\end{array}$} & $\begin{array}{l}\text { Vai ter o quarto pra } \\
\text { ele sim. }\end{array}$ & $\begin{array}{l}\text { sí/no só ocorrem em } \\
\mathrm{PF}^{\mathrm{F}} \text { com expressões } \\
\text { ou em orações } \\
\text { subordinadas }\end{array}$ & $\begin{array}{l}\text { A veces sí } \\
\text { Creo que no } \\
\text { * (?) va a tener la } \\
\text { habitación para ella } \\
\text { sí. } \\
\text { * (?) Dio no. }\end{array}$ \\
\hline & & $\begin{array}{l}\text { Operadores de } \\
\text { Ênfase = sí que em } \\
\text { P'; Sí, sí ou } \\
\text { expressões. }\end{array}$ & $\begin{array}{l}\text { Sí que me acuerdo, } \\
\text { sí. } \\
\text { - La persona con la } \\
\text { que yo me tengo } \\
\text { que entender / es } \\
\text { usted? } \\
\text { - sí, sí sí. } \\
\text { Por supuesto }\end{array}$ \\
\hline $\begin{array}{l}\text { RESPOSTAS } \\
\text { PREFERIDAS }\end{array}$ & & $\begin{array}{l}\text { RESPOSTAS } \\
\text { PREFERIDAS }\end{array}$ & \\
\hline $\begin{array}{l}\text { Atualização do verbo } \\
\text { da pergunta + Obj. } \\
\text { Nulo. }\end{array}$ & $\begin{array}{l}\text { - Já contou? } \\
\text { - Contei. }\end{array}$ & $\begin{array}{l}\text { Sí em } P^{l} \text { antecedido } \\
\text { ou não de Sí em Ppre } \\
\text { e seguido ou não de } \\
\text { outro A + Obj. } \\
\text { (repetido na } \\
\text { pergunta } \\
\text { lexicamente ou por } \\
\text { clítico) }\end{array}$ & $\begin{array}{l}\text { - ¿Y mereció la } \\
\text { pena? } \\
\text { sí, sí mereció la } \\
\text { pena. } \\
\text { * (?) sí, mereció } \varnothing .\end{array}$ \\
\hline
\end{tabular}

Esquema 33 - Síntese comparativa das IPS

Na próxima seção, descreveremos alguns fatores de ordenação do segundo tipo de llocução interrogativa: as de Conteúdo.

Orientação, pois, como já repetimos, parece não haver diferenças para expressão dessa função nas duas línguas, seja em sentenças Declarativas ou Interrogativas. 


\subsection{As Interrogativas de Conteúdo}

Quanto às estruturas das ICs, em PB não há restrições para que os pronomes interrogativos apareçam no início da sentença, pois essa é sua posição icônica, como vemos nos seguintes exemplos:

${ }^{*}$ CAR: quem que é <esse Gilson>?

*VER: <isso> // Gilson <eletricista> // (C-ORAL-BRASIL-bfamcv12)

(39) *JUL: ontem um pastor que tava fazendo campanha lá na igreja / pediu pra gente tá orando pra / mãe daquela menininha que foi jogada da janela / né //

*MAR: uhn //

${ }^{*} E D E$ : que conteceu com ea

*JUL: ahn //

${ }^{*} E D E:$ que conteceu ?/ (C-ORAL-BRASIL-bfamcv15)

Assim, independentemente da categoria semântica (indivíduo, locação, tempo, modo, quantidade ou razão) e do estatuto (núcleo, modificador ou operador), e em EsCos que designam tanto propriedades dinâmicas como não dinâmicas, os elementos interrogados, iconicamente, em PB, posicionam-se no início da Oração, alocando-se, portanto, em $\mathrm{Pl}$. Esses elementos são Subatos, Atributivos (T) ou Referenciais $(R)$, e comunicativamente são salientes e sinalizam a função pragmática Foco. Isso demonstra o que já dissemos anteriormente: que as categorias pragmáticas se sobrepõem às semânticas. Assim, (39) pode ter suas posições representadas da seguinte maneira:

\begin{tabular}{|c|c|c|}
\hline $\mathbf{P}^{\mathbf{I}}$ (FOC) & $\mathbf{P}^{\mathrm{M}}$ & $\mathbf{P}^{\mathrm{M}+1}$ \\
\hline que & aconteceu & com ela \\
\hline
\end{tabular}

Aqui temos uma diferença bastante importante de estruturação das funções pragmáticas entre as Ilocuções Declarativas e Interrogativas de Conteúdo, já que, como havíamos visto anteriormente, se considerarmos somente as estratégias de ordenação, em PB, observamos que, nas Declarativas, muitas vezes Foco ocupa PF. Vemos, aqui, porém, que nas ICs, Foco iconicamente ocupa $\mathrm{P}^{\mathrm{I}}$, por meio de um constituinte $Q$.

No entanto, quando o elemento interrogado constitui um Subato Atributivo no Nível Interpessoal, ou seja, que designa EsCos não dinâmicos, e o único argumento 
é um Inativo, ocorre inversão na posição dos constituintes configuracionais: o elemento interrogado ocupa $\mathrm{P}^{\mathrm{I}} \mathrm{e}$ o único argumento, com função Inativo, ocupa $\mathrm{P}^{\mathrm{M}+1}$, já que o verbo cópula ocupa a posição obrigatória $\mathrm{P}^{\mathrm{M}}$, como vemos no molde de posições do seguinte exemplo:

(40) $190)^{172}$

como foi esse acidente? (Bras80: Acidente, apud PEZATTI \& FONTES, 2010, p.

\begin{tabular}{|c|c|c|}
\hline $\mathbf{P}^{\mathbf{I}}$ & $\mathbf{P}^{\mathbf{M}}$ & $\mathbf{P}^{\mathbf{M}+1}$ \\
\hline como & foi & esse acidente \\
\hline
\end{tabular}

Vemos, nos exemplos de exemplo (38) a (40), que a ordem típica desse tipo de Ilocução (de Subato Atributivo, com argumento Inativo) é VS. Seria bem menos usual, por exemplo, usar a ordem canônica SV, em sentenças como (41):

? como esse acidente foi?

Se, no entanto, temos uma interrogativa com propriedade dinâmica, é possível alocar o argumento tanto antes como depois do predicado, como nos seguintes exemplos:

(42) quanto é que ganha uma empregada? (Bras80: CriarFilhos, apud PEZATTI \& FONTES, 2010, p. 190)

(43) quanto é que uma empregada ganha?

Pezatti \& Fontes (2010) constatam que exemplos como os do par de sentenças (42) e (43) nos indicam que "[...] a ordenação dos constituintes configuracionais nas interrogativas- $Q$ está relacionada ao tipo de frame da predicação" (PEZATTI \& FONTES, 2010, p. 190).

É bastante frequente, no entanto, que o constituinte sobre o qual se interroga ocupe a posição canônica que ocuparia em uma sentença Declarativa, ou seja, que se localize in situ. Porém, segundo Pezatti \& Fontes (2010, p. 191),

\footnotetext{
172 Em nosso corpus não apareceu nenhum exemplo de Interrogativas de Subato Atributivo que não fosse clivado, por isso tomamos este de Pezatti \& Fontes.
} 
Esse tipo de estrutura comumente constitui perguntas retóricas, quer dizer, não se trata de uma busca de informação nova para preencher uma lacuna existente na informação pragmática do Falante, mas sim uma estratégia discursiva do Falante com o objetivo de conseguir uma atenção especial do Ouvinte para um determinado Subato Referencial. Além disso, tais estruturas são comuns em monólogos, como aulas, palestras, em que o falante toma 0 ato enunciativo sem abrir a possibilidade de troca de turnos; a ocorrência das interrogativas- $Q$, nesse caso, subordina-se, portanto, a uma estratégia interativa e discursiva de busca da atenção do Ouvinte para a informação que segue. Nesse caso, no Nível Interpessoal, o Subato Referencial dessas interrogativas deve ser marcado pelo operador $\{-i d,+s\}$, ou seja, não identificável para o Ouvinte, mas específico para o Falante.

O que se depreende da citação acima é que alocar o pronome interrogativo in situ é um recurso para marcação de Ênfase nas ICs, em determinados textos menos interacionais. Talvez pela própria natureza dos textos de nosso corpus, que não contempla monólogos, não encontramos quase nenhuma pergunta retórica. O que constatamos foi, por exemplo, outro recurso enfático que é o de usar apenas o constituinte interrogado, compondo sozinho um Ato Discursivo, como no seguinte exemplo, em que uma das Falantes reage quando Ihe dizem que a convidariam para ser madrinha de casamento: bfamcv02

*JAE: mas é lógico que ea vai pôr ocês / uai //

${ }^{*} R U T$ : não // pra quê??/ eu nũ quero não // Deus me livre // (C-ORAL-BRASIL-

Como vemos em (44), a Falante não espera uma resposta, já que não Ihe falta nenhuma informação.

De qualquer maneira, ainda que não se trate de perguntas retóricas, é bastante frequente alocar os constituintes $Q$ in situ. De fato, essa foi a estrutura que mais encontramos no corpus, como mostram alguns exemplos:

*WOA: <dessa aqui tá quanto>? (C-ORAL-BRASIL-bpubdl02)

*MAR: isso aí é o quê ? (C-ORAL-BRASIL-bfamdl21)

*LUC: cê tá no Gabriela desde quando? (C-ORAL-BRASIL-bpubdl11)

*ANC: essa é quem ? a [/1] <a> + (C-ORAL-BRASIL-bfamcv20) 
Considerando que se trata de pares dialógicos, ou seja, de perguntas e respostas entre ao menos dois participantes (e não de monólogos ou perguntas retóricas), propomos que essas estruturas são estratégias de retomada de Tópico: para dar coesão discursiva ao texto, o Falante prefere manter em $\mathrm{P}^{\mathrm{I}} \mathrm{o}$ constituinte do qual se falava anteriormente e que, portanto, já é conhecido. Por exemplo, em (45), o contexto de conversa é o de uma compradora e um vendedor em uma loja de sapatos, em que ela pergunta o preço de várias sandálias. Para retomar o Tópico sandália e acrescentar mais uma pergunta sobre o mesmo Tópico, ela prefere alocar em $\mathrm{P}^{\mathrm{I}}$ um constituinte que faça referência a esse Tópico (dessa aqui). Mantém-se, assim, a mesma ordem da llocução Declarativa, do que seria a sequência TOP-Comentário, caso se dispusesse da informação faltante (o preço da sandália). Essa ideia é corroborada com o seguinte exemplo, extraído dessa mesma situação comunicativa, que, apesar de ser uma IP, nos serve para mostrar a estratégia que estamos descrevendo:

*JAN: tá // essa aqui / tá quarenta-e-nove e noventa mesmo?

*EUG: não // quarenta-e-nove e noventa é essa // essa aqui é quarenta-e-cinco // (C-ORAL-BRASIL-bpubdI02)

Vemos que, em (49), a Falante recorre a uma Interrogativa Polar, para confirmar uma informação que pensa estar correta. Para isso, ela usa a estrutura da llocução Declarativa, mudando apenas a entonação para Interrogativa (já que a entonação é um tipo de operador de interrogação abstrato) e acrescentando o constituinte mesmo. Temos em (49) o seguinte molde de posições:

\begin{tabular}{|c|c|c|c|}
\hline $\mathbf{P}^{\mathrm{I}}$ (TOP) & $\mathbf{P}^{\mathrm{M}}$ & $\mathbf{P}^{\mathrm{M}+1}$ & $\mathbf{P}^{\mathrm{F}}$ \\
\hline essa aqui & ta & $\begin{array}{c}\text { quarenta } e \\
\text { nove }\end{array}$ & mesmo \\
\hline
\end{tabular}

Nota-se que o Interlocutor responde negativamente à pergunta, usando, o operador de polaridade extraoracional não, que constitui um Ato Discursivo, além do recurso da ordenação para marcar Contraste, alocando o constituinte que ocupava $\mathrm{P}^{\mathrm{M}+1}$ (o argumento do predicado) agora em $\mathrm{P}^{\mathrm{I}}$, e o constituinte que era TOP e ocupava $\mathrm{P}^{\mathrm{I}}$, agora ocupando $\mathrm{P}^{\mathrm{F}}$ (sendo Foco e Contraste): 


\begin{tabular}{|c|c|c|}
\hline $\begin{array}{c}\mathbf{P l}^{\mathrm{I}} \\
(\mathrm{TOP})\end{array}$ & $\mathbf{P}^{\mathrm{M}}$ & $\begin{array}{c}\mathbf{P F} \\
(\mathrm{FOC})\end{array}$ \\
\hline quarenta e nove & & essa \\
\hline
\end{tabular}

Esse trajeto nos faz voltar ao exemplo (45) e justificar que, além de retomar e manter o TOP em $\mathrm{P}^{\prime}$ como se faria em uma llocução Declarativa (ou em uma Interrogativa Polar, como vimos), o Falante também se vale da estratégia de colocar o pronome interrogativo em $\mathrm{PF}$, ou seja, a posição que seria ocupada pelo constituinte focal, como vimos em (49), com valor de Contraste, comparando o preço dessa sandália com os outros preços de outras sandálias que o vendedor já Ihe havia apresentado. Em resumo, temos uma estratégia dupla de ordenação: para manutenção do Tópico (mantendo TOP em $\mathrm{P}^{\prime}$ ) e para marcação de Foco e/ou Contraste (colocando o constituinte $\mathrm{Q}$ em $\mathrm{PF}$ ).

No exemplo (50), vemos o uso da mesma estratégia, ou seja, colocar o pronome interrogativo posposto aos constituintes que retomam aquilo de que se estava falando anteriormente, neste caso, como forma de aclarar a pergunta:

(50) *MAR:cê lembra se cê / quando cê foi entregar os documentos $+\$$

*MAR: eu / esqueci de [/1] de [/1] até de + \$

*MAR: se ocê colocou carta de intenção?

${ }^{*} E R N$ : onde?

${ }^{\star} E R N$ : entregar documento onde?

*MAR: pra deerreí //\$

Em EP, nossos dados mostraram que o constituinte $Q$ tende a ocupar sempre $\mathrm{P}^{\mathrm{I}}$, como podemos ver nos seguintes exemplos:

*PIL: oye / cuándo has empezado este año?\$ (C-ORAL-ROM-efamdl01).

[Quando você começou este ano?]

*LUI: y el viaje de ida / para allá / o el de vuelta / se hace largo?\$

${ }^{*}$ CRI: a dónde?\$ aquí a España ?\$ (C-ORAL-ROM-efamcv15).

[Pra onde? Aqui para a Espanha?]

\footnotetext{
${ }^{173}$ Aqui, não interpretamos este verbo ser como copulativo, pois poderia ser parafraseado por custar, por isso não estamos analisando essa sentença como sendo de identificação.
} 
(53) *PIE: pero sabes del dinero que le dan a Raquel Mosquera?\$

*PAZ: cuánto <le dan>?\$ (C-ORAL-ROM-efamdl33).

[Quanto lhe dão?]

[Quanto pagam para ela?]

(54) $\quad$ *PAT: $[<]<$ qué te queda?\$ casarte $>/ / \$$ te queda casarte $/ / \$$ es que es así $/ / \$(\mathrm{C}$ ORAL-ROM-efamcv05)

[O que te resta? Casar(te)]

[O que resta pra você? (Se) casar.]

Em nosso corpus, não houve ocorrências de constituinte $Q$ in situ, opostamente do que encontramos em PB, cuja principal posição do constituinte $Q$ é justamente in situ. Em PB, interpretamos a alocação de $Q$ in situ como recurso para manter o Tópico em $\mathrm{P}^{\mathrm{I}}$, como elemento de coesão discursiva e para que se mantenha o constituinte focal em PF, como ocorre nas llocuções Declarativas. Visto que essa estratégia não é usual em EP, concluímos que, em EP, ao menos nos dados que obtivemos em nosso corpus, nas ICs prefere-se manter o Foco (constituinte Q) em $\mathrm{P}^{\prime}$. No entanto, em EP há uma alta produtividade de expressões como ¿Y eso qué?, expressão que equivaleria a $E$ daí? em PB. Trata-se, portanto, de uma expressão cristalizada na língua, na qual o constituinte $Q$ não tem a real função de interrogar sobre uma informação desconhecida.

Segundo Pezatti \& Fontes (2010), o posicionamento de Q in situ, no PB, é um recurso para a marcação de Ênfase em textos menos interacionais, compondo, muitas vezes, perguntas retóricas que, na verdade, não requerem uma informação, mas chamam a atenção do Ouvinte para a informação que segue (como, por exemplo, em E eu fiz o quê? Fui embora). Em EP, esse recurso retórico também existe, em estruturas como ¿Y yo qué hice? Me fui ou ¿Qué hice yo? Me fui. Percebemos, assim, que, em EP, constroem-se as perguntas retóricas por meio de expressões fixas e que esses são os contextos discursivos que permitem uma maior liberdade de ordenação do constituinte $Q$, como vemos nos exemplos:

(55) *MAR: [<] <habría que construir> / una especie de / hhh / cómo le diría yo?\$ como de / cobertizo o algo así //\$ (C-ORAL-ROM-epubdI04).

[como lhe diria eu?]

[como eu te diria/diria pra você?] 
*LUI: $[<]<x x x>/ /$ yo qué sé?\$ (C-ORAL-ROM-efamcv02)

[eu o que sei?]

[(eu) sei lá]

Em (56) a expressão yo qué sé (da mesma maneira que sua variante ¿Qué sé yo?) poderia ser traduzida ao PB por algo como (Eu) sei lá. Nota-se, portanto, que não se tratam de ICs típicas, que requeiram alguma informação. Em (55), temos o constituinte $\mathrm{Q}$ com função de Foco ocupando $\mathrm{P}^{\mathrm{I}}$, o clítico ocupando $\mathrm{P}^{\mathrm{M}-1}$, o predicado ocupando $\mathrm{PM}^{\mathrm{M}}$ e o constituinte com função sintática de Sujeito e pragmática de Tópico ocupando $\mathrm{PF}$, como recurso enfático, como vemos no esquema de posições abaixo:

\begin{tabular}{|c|c|c|c|}
\hline $\begin{array}{c}\mathbf{P I}^{\mathrm{I}} \\
\text { FOC }\end{array}$ & $\mathbf{P}^{\mathrm{M}-1}$ & $\mathbf{P}^{\mathrm{M}}$ & $\begin{array}{c}\mathbf{P F}^{\mathrm{F}} \\
\text { TOP/Ênf }\end{array}$ \\
\hline ¿Cómo & le & diría & $y o ?$ \\
\hline
\end{tabular}

O último recurso de construção das ICs que nos interessa comentar é o que aparece naquelas enfatizadas por um expletivo (-é que/que/es que), ou seja, as construções clivadas, as quais, no entanto, já abordamos no capítulo 4, quando explicados alguns recursos de Ênfase nas duas línguas, razão pela qual só retomaremos algumas sentenças aqui a fim de aclarar a memória do leitor: Quem que é esse Gilson? / Sabe que que eu penso? / Cómo es que la han adelantado no sé?. $\mathrm{Na}$ seção sobre Ênfase, vimos que o EP, diferentemente do $\mathrm{PB}$, não habilita o expletivo que como recurso exclusivo de enfatizar constituintes em ICs. No lugar desse expletivo, o EP prefere enfatizar determinados elementos em ICs por meio da estrutura es que, como na sentença que retomamos acima, ou de uma clivada do tipo ¿Sabes lo que pienso yo?

Perini (2010) também constata algo importante para nossa análise: em PB, quando o pronome interrogativo ocupa $\mathrm{P}^{\mathrm{I}}$, é possível que haja inversão na posição sintática do Sujeito, como ocorre em (57), trazido por ele: 
Embora (58) seja possível, segundo o autor, é mais comum manter o Sujeito em sua posição sintática canônica, preferindo-se, segundo o autor, (85) a (84):

Quando foi que o seu avô morreu? (PERINI, 2010, p. 126)

Exemplos como (57) e (58) podem ser explicados pelo tipo de verbo monoargumental, morrer, que, como explicamos anteriormente, apresenta a ordem VS por força histórica dessa ordenação. Portanto, os critérios de restrições para a inversão do Sujeito nas Ilocuções Interrogativas são os mesmos das llocuções Declarativas, levando em consideração as funções semânticas do constituinte com essa função sintática, como explicamos anteriormente. Assim, orações como as seguintes seriam incoerentes em PB:

? O que comeu você no jantar?

(60) ? Quando encontrou a Cláudia o canivete?

\begin{tabular}{|c|c|c|c|}
\hline $\mathbf{P}^{\mathbf{l}}$ & $\mathbf{P}^{\mathbf{M}}$ & $\mathbf{P}^{\mathbf{M + 1}}$ & $\mathbf{P}^{\mathbf{F}}$ \\
\hline o que & comeu & você & no jantar \\
& & (Ator) & \\
\hline
\end{tabular}

\begin{tabular}{|c|c|c|c|}
\hline $\mathbf{P}^{\mathbf{I}}$ & $\mathbf{P}^{\mathbf{M}}$ & $\mathbf{P}^{\mathbf{M}+1}$ & $\mathbf{P}^{\mathbf{M}+2}$ \\
\hline quando & encontrou & a Cláudia & o canivete \\
& & (Ator) & (Inativo) \\
\hline
\end{tabular}

As sentenças (59) e (60) são incoerentes porque a função semântica dos constituintes você e Cláudia é de Ator, e em PB, a única maneira de marcar essa função, como já vimos, é por meio da ordenação: em posição à esquerda do predicado, já que a posição à sua direita é reservada para os constituintes com função semântica Inativo, no caso de EsCos com propriedades dinâmicas.

Observemos que essa restrição semântica também existe se os constituintes Q estiverem in situ, como aconteceria, por exemplo, se mudássemos (59) para a seguinte estrutura: 
O exemplo (61) continua incoerente, pois, independentemente da posição do constituinte $Q$, o que rege a ordenação são dois fatores: propriedade do Ato Discursivo (dinâmico vs. não dinâmico) e relação entre o predicado e seus argumentos: Ator precisa estar à sua esquerda e Inativo e Locativo, à sua direita.

González (2014) faz a análise de uma propaganda que suscita a problemática do que estamos abordando aqui, inclusive com o mesmo verbo (comer) em uma Ilocução Interrogativa traduzida do PB para o E. Tratava-se de uma rede brasileira de supermercados, que à época adotou o slogan O que faz você feliz?. Em 2008, essa rede lançou uma campanha com o intuito de vender produtos da gastronomia espanhola e, para isso, criou um panfleto escrito, de um lado em português e de outro, teoricamente, em espanhol. Abaixo reproduzimos esse panfleto escrito em espanhol, (GONZÁLEZ, 2014, p. 8):

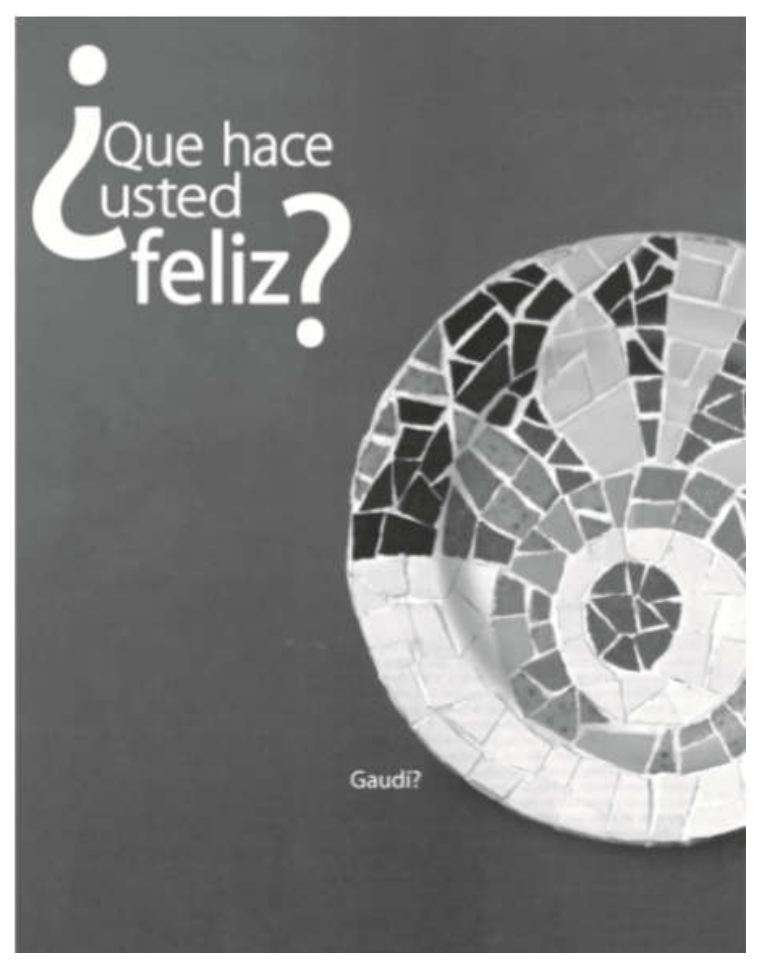

Figura 13 - Folheto publicitário ¿Qué hace usted feliz?

González (2014) diz que todo o contexto ajudava a que um possível leitor hispanoparlante pudesse entender a propaganda. No entanto, a autora nos diz que fora desse contexto, ante a pergunta ¿Qué hace usted feliz?, 
[...] algum falante do espanhol talvez se assustasse com o que poderia soar para ele como "Você/O senhor está feliz por quê?". E que poderia complementar com "Está doido? Tem motivos para estar feliz?". Ou simplesmente poderia entendê-la como uma pergunta sobre hábitos: "O que você/o senhor faz quando se sente feliz?". E, cremos, muito dificilmente chegaria ao que era o sentido esperado para o slogan: uma indagação sobre o que poderia deixá-lo feliz (GONZÁLEZ, 2014, p. 10).

A autora propõe, então, para evitar essas ambiguidades, que a pergunta do PB O que faz você feliz? fosse traduzida por ¿Qué te hace feliz? (a ti/a vos) / ¿Qué le/lo/la hace feliz? (a usted) / ¿Qué te/le trae felicidad? (a ti/a vos/a usted). A autora explica que as posibilidades de tradução ao $\mathrm{E}$ deveriam considerar que nessa língua o elemento afetado, com função sintática de Objeto (o Inativo, da GDF) muito provavelmente seria expresso por pronomes clíticos. Se o Inativo fosse expresso por uma forma tônica (como no caso do slogan, usted), ele necessariamente deveria vir antecedido pela preposição a, a fim de não ser confundido com o Sujeito/Ator. No PB, ao contrário, é a ordem dos constituintes que indica que você é o Objeto/Inativo, já que se aloca à direita de $\mathrm{PM}$. Caso se desejasse que você fosse interpretado como Sujeito/Ator, ele deveria estar posicionado à esquerda de $\mathrm{PM}^{\mathrm{M}}$, em uma sentença como O que você faz feliz?. Esse exemplo, portanto, nos serve para retomar toda a discussão que apresentamos no capítulo 3 sobre como as funções semânticas dos constituintes em PB determinam/restringem sua ordenação.

Como vemos, essa restrição no posicionamento dos Sujeitos nas ICs não se aplica ao E, como mostramos no exemplo a seguir:

\section{*UEL: en qué parte de Murcia / vive tu madre?\$ (C-ORAL-ROM-efamdI20)}

O exemplo acima nos mostra que os constituintes com função sintática Sujeito e função semântica Ator ocupam posições à direita de $\mathrm{PM}^{\mathrm{M}}$, mantendo, portanto, as mesmas características de ordenação que descrevemos nas llocuções Declarativas (e as mesmas assimetrias com o PB).

Para terminar esta seção, o último ponto a ser analisado são as respostas dadas a essas ICs, em PB. Como já falamos no início deste subitem, não pretendemos analisar todas as configurações de respostas, pois isso envolveria diversos fatores, tais como coerência, manutenção temática, entre outros, que definitivamente não poderão ser abordados neste momento. No entanto, um tipo muito comum de resposta 
a ICs são aquelas constituídas por apenas um sintagma (mais ou menos aos moldes do que vimos nas respostas das IPs, quando o Falante apenas atualiza o verbo da pergunta). Aqui, ao invés de usar o verbo da pergunta, o que se costuma fazer é usar um constituinte com função semântica que completa a lacuna de informação do Interlocutor, representada pelo constituinte Q. Assim, voltando à codificação das diferentes categorias semânticas nas ICs, se em um predicado dinâmico se interroga sobre um indivíduo (x), por exemplo, por meio do pronome quem, uma provável resposta será constituída apenas por um constituinte com função semântica Ator, como nos exemplos a seguir:

${ }^{*} B A L:$ quem te contou?

${ }^{\star} E L N:$ Marco $/ / \$$

${ }^{*} B A L:$ ah / tá //\$ (C-ORAL-BRASIL-bfamdl08)

${ }^{*} E M F:$ quem que \&re [/1] resolveu na escola?

${ }^{*} F L L:<a$ menina que ela> / <já tinha dado> <o carimbo> // \$

*MIC: <minha amiga $>/ / \$$ (C-ORAL-BRASIL-bfamcv26)

Em (63) e (64), temos predicados dinâmicos, com verbos que exigem mais de um argumento (contar e resolver). A informação que preenche a lacuna interrogada pelo quem, nos dois casos, é ocupada por um constituinte com função semântica Ator

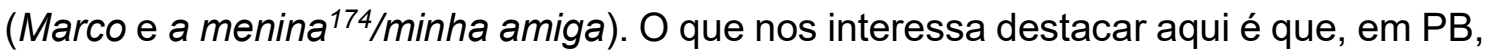
nesse tipo de IC nem sempre se repete o verbo da pergunta e também nem sempre se retoma o argumento Inativo (contar algo, resolver algo), que ficam, portanto, apenas implícitos no Componente Contextual: estão ativados na memória discursiva dos participantes, e isso é suficiente para que não sejam obrigatoriamente retomados linguisticamente.

O mesmo ocorre com verbos como jogar, no exemplo abaixo. Como veremos, essa não será uma diferença com o EP, que para verbos monoargumentais também permite respostas sintagmáticas com função de Foco:

*SIL: quem tá jogando?

${ }^{*}$ GUI: acho que é a Inglaterra//\$ ${ }^{175}$ (C-ORAL-BRASIL-bfamdI04)

\footnotetext{
${ }^{174}$ Embora na resposta se trate de uma Oração adjetiva especificativa, seu núcleo é o termo a menina. 175 Aqui, trata-se de sentenças encaixadas (subordinadas), mas o constituinte a Inglaterra é o sintagma focal, que carrega a informação nova relevante, e cujo verbo (jogar) é retomado apenas contextualmente.
} 
Em PB, quando o Falante recorre a uma resposta oracional para as ICs, ou seja, constituída por um predicado (e seus argumentos), nossa proposta é que essa seja uma estratégia de marcação de Foco ou Contraste, como vimos em um exemplo do capítulo 4, que retomamos aqui como (66):

*LAU: Quem que falou?

*LUZ: gente / eu / te falei / a Fabíola / eu falei se ocê nũ faria // (C-ORAL-BRASIL bfamdl03).

Como explicamos anteriormente, o Contraste pode ser percebido tanto pela entonação, ou seja, pela mudança de tessitura nos constituintes eu e Fabíola, que marcam Focos, pois são os dois constituintes com função semântica Ator: são elas que falam para o Interlocutor (que faz a pergunta), no nosso exemplo, sobre um concurso que haverá. Vemos, agora, que essa estratégia entonacional é reforçada pela preferência de usar uma resposta oracional e não apenas sintagmática.

Encontramos aqui mais uma assimetria entre as duas línguas, já que em EP é comum que as respostas das ICs, mesmo com predicados que exigem mais de um argumento, sejam constituídas por mais de um sintagma, como vemos abaixo: $+\$$

${ }^{*} E L E:[<]<i a y !$ / qué> hicisteis con lo del casete del coche?\$ que os ibais a <llevar> ${ }^{*} \mathrm{CRI}:[<]<$ no $>$ llevamos casete $/ / \$$ al final //\$ porque / se lo encargué a / Quique / (C-ORAL-ROM-efamdl08)

Em (73), a predicação do verbo encargar, que exige 3 argumentos, apresenta explicitamente dois deles (os complementos se, lo e a Quique, expressão que duplica o se e tem um valor claramente contrastivo: a Quique y no a otra persona), deixando implícito apenas o argumento que teria função de Sujeito (yo).

\subsubsection{A hipótese da gradualidade de pragmatismo}

Os dados que apresentamos ao longo desta seção nos indicaram que nas ICs, o PB tende a manter Foco em $\mathrm{P}^{\mathrm{I}}$, apesar de ser livre para posicioná-lo em outras posições. Para a alocação dos Sujeitos/Atores/Tópicos, o PB mantém as mesmas restrições semânticas e Configuracionais que as descritas para as sentenças Declarativas, mantendo-os muito mais fixamente em $\mathrm{P}^{\prime}$. Também como nas 
Declarativas, nas ICs o PB tende fortemente a expressar os Sujeitos, como vimos em (50): cê lembra se cê / quando cê foi entregar os documentos [...] se ocê colocou carta de intenção?

Já em EP o constituinte $Q$ (Foco) está mais restrito à $\mathrm{P}^{\prime}$. E, assim como nas Declarativas, nas ICs mantém-se o mesmo padrão para os Sujeitos: preferência de marcá-los com $\varnothing$ quando não têm valor contrastivo - ¿Qué hicisteis con lo del casete del coche? - e de expressá-los somente quando são ou Contrastivos - ¿Sabes lo que pienso yo? (note-se que temos um verbo que expressa opinião, ponto de vista, e que, como já comentamos, esses verbos são propícios para marcar Contraste) ou desambiguadores de terceira pessoa - ¿En qué parte de Murcia vive tu madre? Segundo nossa interpretação, essa função desambiguadora não deixa de ser um contraste, já que faz um recorte de todas as possibilidades de pessoas a que o verbo na terceira pessoa poderia se referir: o Falante quer saber onde vive a mãe e não a tia, ou o primo, ou usted, etc.

A divergência nas duas línguas entre os padrões de lexicalização e pronominalização dos Sujeitos, por um lado, ou sua omissão, por outro, pode ser facilmente verificada pela comparação da sentença (51), original em EP, e sua tradução ao PB:

¿Cuándo $\varnothing$ has empezado este año?

[Quando você começou este ano?]

Em todos esses exemplos citados/comparados, os Sujeitos correspondem aos Tópicos das sentenças, o que, corrobora nossa hipótese: quando não contrastivo, o constituinte Sujeito Tópico se manifesta como $\varnothing$ em EP. Quando realizado, carrega também a função Contraste. Ou seja, mostra-se outra vez, mesmo nas ICs, o processo de não topicalização dos Sujeitos em EP.

Uma das teses que defendemos, como já explicamos quando falamos sobre os Tópicos duplicados em EP, é que existe uma gradualidade de pragmatismo dos constituintes e que constituintes mais pragmáticos (aqueles que carregam concomitantemente mais de uma função pragmática) têm preferência para ocupar posição absoluta nas posições periféricas da Oração. Como mostramos aqui, os constituintes que são Tópicos e que também são Contrastes ocupam, portanto, posição absoluta de PF. Alocar esse constituinte à direita do Predicado, ainda que em 
uma posição de domínio de $\mathrm{P}^{\mathrm{I}}$, seria afastá-lo da posição absoluta e tirar-lhe força pragmática, atribuindo-Ihe somente a função de Tópico, caso que não corresponderia à intencionalidade do enunciado. O vetor abaixo mostra graficamente nossa proposta entre gradualidade de pragmatismo e posicionamento dos constituintes nas ICs:

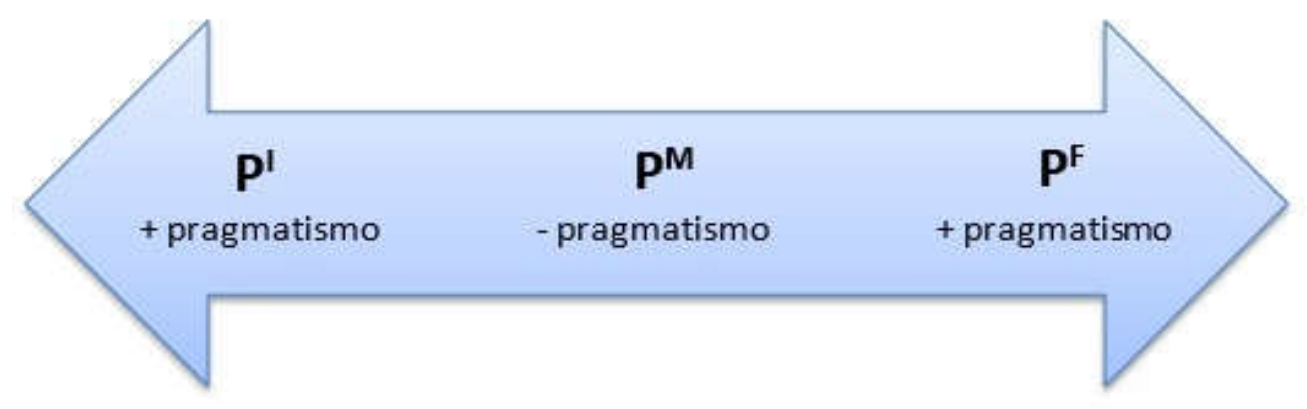

Figura 14 - Vetor gradualidade do pragmatismo

Outra característica importante a ser descrita é que, em EP, quando, por uma das duas razões que acabamos de mostrar, o Sujeito precisa ser expresso, ele ocupará PF. Parece aqui não se tratar mais de uma preferência, mas sim de uma restrição que, se não cumprida, gera sentenças tidas como agramaticais ou dificilmente aceitáveis para muitos hispanoparlantes ${ }^{176} \mathrm{e}$, inclusive, para alguns estudiosos da língua, como Fernández Soriano (1993), como mostramos no capítulo Zero. Essas sentenças seriam * ¿Sabes lo que yo pienso? ou “ ¿En qué parte de Murcia tu madre vive? Essas mesmas ordens evitadas em EP seriam, seguramente, as preferidas em PB: Sabe o que eu penso? / Em que lugar de Murcia sua mãe mora? Em PB, a tendência de posicionamento dos Sujeitos Tópicos em $\mathrm{P}^{\mathrm{l}+1}$ indica que, nessa língua, essa é a ordenação básica, canônica, não carregada de Contraste. É apenas Tópico e, por isso, pode não ocupar nenhuma posição absoluta. Para marcar Contraste sobre esses constituintes em PB, portanto, pensamos que o principal recurso seria manter a mesma ordem, mas marcando prosodicamente o constituinte contrastado: Onde SUA MÃE mora? Pode-se, ainda que menos frequentemente, recorrer à mudança de ordem: $A$ sua mãe mora em que lugar de Murcia? Essa ordenação alternativa, manteria o constituinte mais carregado

176 Para afirmar seguramente que sentenças como essas são, de fato, agramaticais na língua, teríamos que fazer um estudo detalhado dela em diversas variedades e variantes e em diversos contextos, estudo esse que não realizamos nesta tese. 
pragmaticamente em uma posição absoluta externa - $\mathrm{P}^{\mathrm{l}}$ - , confirmando nossa proposta.

Essa estratégia do PB se vincula a outra que fomos descrevendo ao longo desta seção: a preferência de alocar os constituintes $\mathrm{Q}$ em $\mathrm{P}^{\prime}$ : manter o Foco em $\mathrm{P}^{\mathrm{I}}$ significa manter o Tópico não contrastivo em $\mathrm{P}^{1+1}$ (uma posição de menor saliência pragmática) e reservar, assim, $\mathrm{PF}^{\mathrm{F}}$ para os Tópicos Contrastivos (mais carregados pragmaticamente, portanto). Abaixo, apresentamos os esquemas comparativos de posicionamentos de um dos exemplos citados, além de dois esquemas mais, que servem somente de base para mostrar a ordenação não contrastiva nas duas línguas:

\begin{tabular}{|c|c|}
\hline $\mathbf{P}^{\mathbf{I}}$ & $\mathbf{P}^{\mathrm{M}}$ \\
\hline FOC & \\
\hline ¿Dónde & $\varnothing$ vives? \\
\hline
\end{tabular}

\begin{tabular}{|c|c|c|}
\hline PI & $\mathbf{P}^{\mathbf{I}+1}$ & $\mathbf{P}^{\mathbf{M}}$ \\
\hline FOC & TOP & mora? \\
\hline Onde & você & . \\
\hline
\end{tabular}

\begin{tabular}{|c|c|c|}
\hline $\begin{array}{c}P^{\prime} \\
\text { FOC }\end{array}$ & $\mathbf{P M}^{\mathrm{M}}$ & $\begin{array}{c}\mathbf{P F}^{\mathrm{F}} \\
\text { TOP + CONTR. }\end{array}$ \\
\hline ¿En qué parte de Murcia & vive & tu madre? \\
\hline
\end{tabular}

\begin{tabular}{|c|c|c|}
\hline $\mathbf{P}$ & $\mathbf{P}^{\mathbf{l}+1}$ & $\mathbf{P}^{\mathbf{M}}$ \\
\hline FOC & TOP & \\
\hline Em que lugar de Murcia & sua mãe & mora? \\
\hline
\end{tabular}

\begin{tabular}{|c|c|c|}
\hline $\mathbf{P}^{\mathbf{I}}$ & $\mathbf{P}^{\mathrm{M}}$ & $\mathbf{P F}$ \\
TOP + CONTR & & FOC \\
\hline Sua mãe & mora & em que lugar de Murcia? \\
\hline
\end{tabular}

Vejamos como essas ideias se sintetizam nos seguintes esquemas: 

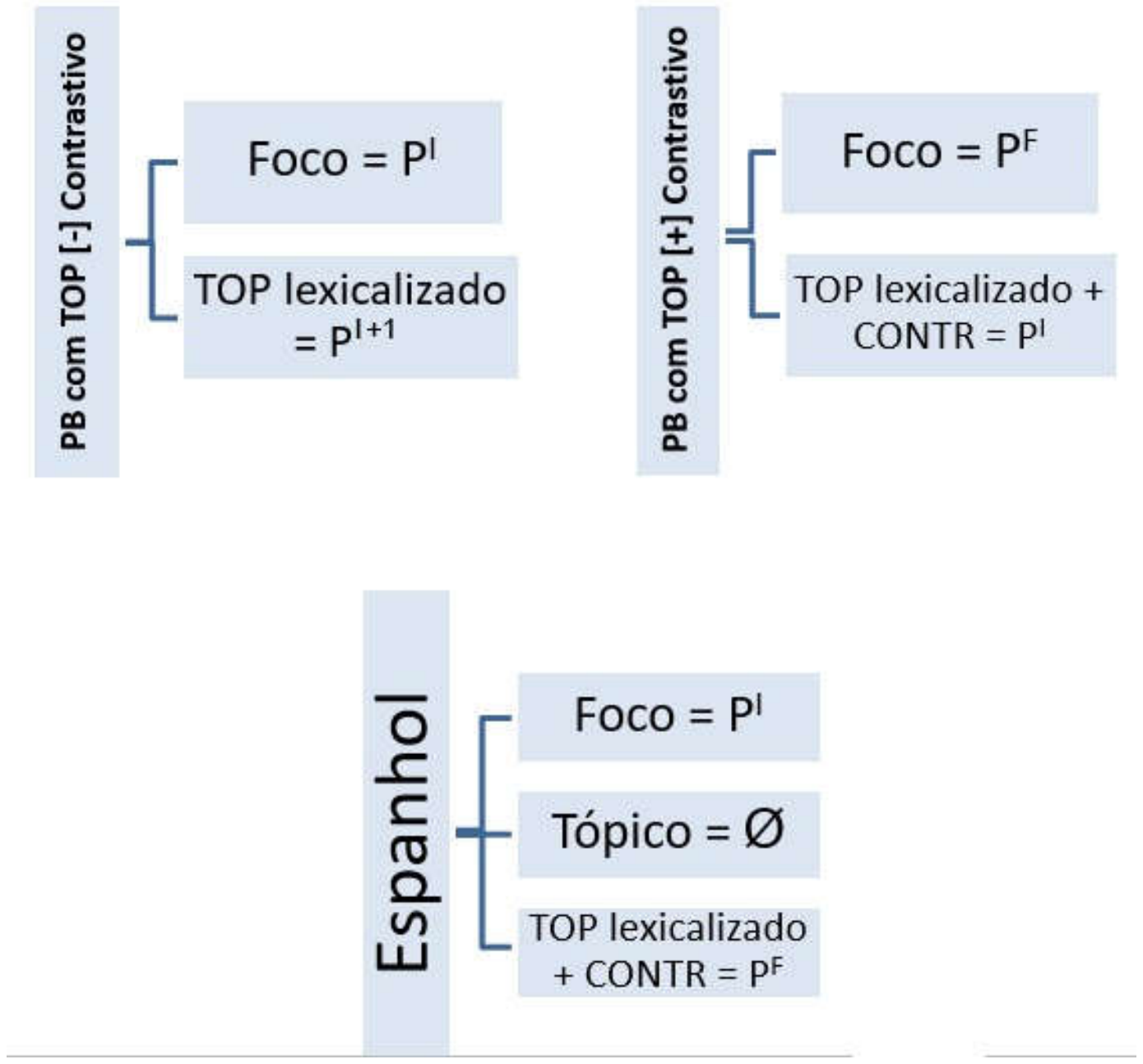

Esquema 34 - Proposta de posicionamento para constituintes pragmáticos nas ICS

Além das questões descritas nos gráficos anteriores, o seguinte quadro traz algumas outras considerações que mais se relacionam aos nossos objetivos e que são específicos das ICs: 


\section{ICs - SÍNTESE COMPARATIVA}

\begin{tabular}{|c|c|c|c|}
\hline \multicolumn{2}{|r|}{ PB } & \multicolumn{2}{|r|}{ EP } \\
\hline $\begin{array}{l}\text { Ordem VS: só com } \\
\text { EsCos [- din.] ou com } \\
\text { verbos } \\
\text { monoargumentais }\end{array}$ & $\begin{array}{l}\text { Como foi esse } \\
\text { acidente? } \\
\text { Quando foi que } \\
\text { morreu o seu avô? }\end{array}$ & $\begin{array}{l}\text { Ordem VS: parece } \\
\text { não ter restrição. }\end{array}$ & $\begin{array}{l}\text { Vide exemplos do } \\
\text { último quadro. }\end{array}$ \\
\hline $\begin{array}{l}\text { EsCos [+ din.]: } \\
\text { argumento ou depois } \\
\text { do predicado }\end{array}$ & $\begin{array}{l}\text { Quanto é que ganha } \\
\text { uma empregada? } \\
\text { Quanto é que uma } \\
\text { empregada ganha? }\end{array}$ & & \\
\hline $\begin{array}{l}\text { Frequente Operador } \\
\text { de } \\
\text { escopando Q Énfase }\end{array}$ & $\begin{array}{l}\text { Quem que é esse } \\
\text { Gilson? }\end{array}$ & $\begin{array}{l}\text { Ênfase: es que, ou } \\
\text { clivada }\end{array}$ & $\begin{array}{l}\text { Cómo es que la han } \\
\text { adelantado no sé? } \\
\text { ¿Sabes lo que } \\
\text { pienso yo? }\end{array}$ \\
\hline $\begin{array}{l}\text { Propriedade } \\
\text { Configuracional de } 3 \\
\text { lugares: Suj. Ator = à } \\
\text { esquerda de PM e } \\
\text { expresso } \\
\text { Objeto. } \\
\text { Inativo/Locativo = à } \\
\text { esquerda de } \mathrm{P}^{\mathrm{M}}\end{array}$ & $\begin{array}{l}\text { O que você comeu } \\
\text { no jantar? } \\
\text { * ? O que comeu } \\
\text { você no jantar? }\end{array}$ & $\begin{array}{l}\text { Propriedade } \\
\text { Configuracional de } 3 \\
\text { lugares: Suj. Ator = } \\
\text { direita de } \mathrm{P}^{\mathrm{M}} \text { e Obj. } \\
\text { Inativo/Locativo = à } \\
\text { esquerda de } \mathrm{PM} \text {, com } \\
\text { clítico }\end{array}$ & $\begin{array}{l}\text { ¿En qué parte de } \\
\text { Murcia vive tu } \\
\text { madre? } \\
\text { ¿Qué te hace feliz? } \\
\text { *? ¿Qué hace usted } \\
\text { feliz? }\end{array}$ \\
\hline
\end{tabular}

Esquema 35 - Síntese comparativa das ICS

Terminamos aqui nosso percurso comparativo entre as llocuções Interrogativas nas duas línguas. Temos consciência de que os elementos que apresentamos aqui de nenhuma maneira esgotam as questões relacionadas às ordenações das llocuções Interrogativas nessas duas línguas. No entanto, tentamos abordar algumas características relevantes para a comparação entre elas, aquelas que nos parecem mais relevantes neste momento, já que não teríamos como dar conta da totalidade dos casos.

A seguir, retomamos e revisitamos os objetivos que tivemos ao longo deste trabalho, para, então, apresentarmos nossas considerações finais. 


\section{CAMINHANDO RUMO ÀS CONSIDERAÇÕES FINAIS...}

\section{FATORES DE ANÁLISE, OBJETIVOS E HIPÓTESES REVISITADOS}

Como dissemos no início desta tese, devido à densidade e à diversidade dos conceitos teóricos que apresentamos, pareceu-nos adequado deixar para o final do trabalho uma apresentação mais minuciosa dos fatores que foram considerados nas análises que fizemos. Para isso, dividimos essa seleção de fatores em dois grupos: os gerais, propostos pela GDF como ferramentas de análise da ordenação de qualquer língua; e os específicos, que selecionamos para comparar alguns dos fatores de ordenação que queremos destacar entre o PB e o EP.

\section{Fatores considerados nas análises das ordenações, segundo a GDF}

\section{Fatores gerais}

Por serem gerais, pressupõe-se que esses fatores sejam suficientes para descrever todos os tipos de constituintes nas línguas. Como não poderia ser diferente, dada a interconexão entre formas e funções nas línguas e a complexidade de fatores que podem interferir na ordenação dos constituintes, além das motivações pragmáticas, em nossas análises também foram considerados os fatores estruturais, semânticos e sintáticos, especificados a seguir (considerando uma análise da ordenação sob a perspectiva da GDF):

1. Supremacia da Pragmática sobre a Semântica e dessas sobre a Sintaxe.

2. O inventário dos Moldes de Conteúdo (construções Téticas ou Categoriais).

3. Os Moldes de Predicação (de Propriedades de zero lugar, de um lugar, de dois lugares ou de três lugares).

4. Dinamicidade ou não dinamicidade do Estado-de-coisas (EsCos).

5. As funções semânticas dos constituintes de Propriedade Configuracional: (i) Ator (Actor), Inativo (Undergoer) e Locativo (Locative). 
6. O tipo de llocução.

7. Questões de alinhamento, para analisar a ordenação de constituintes Configuracionais.

8. Questões de escopo, para analisar a ordenação de constituintes hierárquicos.

8. A possibilidade de existência de constituintes no nível da Expressão Linguística, além do nível oracional.

9. O molde de posições disponíveis nas duas línguas (Ppre, $\mathrm{P}^{\mathrm{I}}, \mathrm{PM}^{\mathrm{M}}, \mathrm{PF}^{\mathrm{E}} \mathrm{e}$ Ppos).

Além desses fatores, foi preciso nunca perder de vista que, segundo a perspectiva teórica que adotamos neste trabalho, a atribuição de uma posição a um constituinte, no Nível Morfossintático, deve considerar: (i) os inputs do Nível Interpessoal, ou seja, as funções pragmáticas desempenhadas por esses constituintes (Tópico, Foco ou Contraste); (ii) os inputs recebidos do Nível Representacional, ou seja, as funções semânticas desempenhadas por esses constituintes (Ator, Inativo ou Locativo); (iii) a atribuição dessas funções no Nível Morfossintático (desempenhando as funções sintáticas de Sujeito ou Objeto).

Por toda a complexidade de fatores a serem considerados na ordenação, e considerando a proposta da GDF e as conclusões de Pezatti (1994, 2014), de Marques (2012), de Fernández Soriano (1993) e de Padilla García (2001) de que, tanto para o português como para o espanhol, os critérios pragmáticos (intencionais) e de informatividade são os que motivam a forma das Expressões Linguísticas na interação, não nos pareceu que analisar a ordenação tomando por base um padrão sintático (SVO ou qualquer uma de seus arranjos) fosse o caminho mais adequado. Sendo assim, esses padrões de ordenação foram, na verdade, secundários durante todo o trabalho, e foram considerados consequências de outros fatores.

Assim, vimos a necessidade de fazer mais um recorte de pesquisa. A seguir, descrevemos quais dos critérios acima foram selecionamos para este trabalho, já que não tivemos a pretensão de analisar a ordenação de todos os tipos de constituintes. 


\section{Fatores selecionados para esta pesquisa}

Para nossas análises, usamos os seguintes critérios, dentre os fatores gerais listados anteriormente. Todos os recortes feitos se justificaram por termos hipóteses de que esses fatores fossem os que mais gerariam diferenças de ordenação no PB e no EP (embora, obviamente, um trabalho comparativo pressuponha também semelhanças entre as línguas comparadas, como também fomos apontando ao longo dos capítulos).

1. O nível de análise se centrou no Ato Discursivo, que algumas vezes foi constituído por apenas um Sintagma, como vimos nas respostas mais típicas de llocuções Interrogativas Polares no PB, bem como em constituintes com função retórica de Esclarecimento e em alguns com função retórica de Orientação (que podem ser sintagmáticos ou não, de acordo com nossa proposta). O fato de termos considerado esses constituintes sintagmáticos, porém, não significa que tenhamos centrado nosso trabalho em análises da ordenação no nível do Sintagma, uma vez que não nos detivemos em descrever as partes dos Sintagmas (determinantes em relação a nomes, por exemplo, nem posições $\mathrm{P}^{\mathrm{I}}, \mathrm{P}^{\mathrm{M}}, \mathrm{P}^{\mathrm{F}}$, etc. do nível sintagmático.

2. Do inventário de Moldes de Conteúdo, selecionamos analisar principalmente as construções Téticas e as Categoriais de um, dois e três lugares (excluindo as de lugar zero).

3. Quanto ao tipo de EsCos, selecionamos principalmente os dinâmicos, só comentando alguns fatores relacionados aos [-din] quando eram necessários para a comparação.

4. Dos tipos de llocuções, selecionamos as Declarativas e as Interrogativas, e entre estas, as Polares e as de Conteúdo.

5. Analisamos principalmente constituintes Configuracionais, abordando somente de maneira muito breve, portanto, questões relativas aos constituintes que fossem operadores ou modificadores (mesmo que eles tivessem função pragmática, como, por exemplo, os Tópicos que indicam cenário de EsCos). Dentre os poucos operadores que integraram nossas análises estão alguns operadores de Ênfase, somente para diferenciar essa categoria pragmática das funções de Contraste e Foco. 
6. Analisamos tanto constituintes oracionais como extraoracionais, ou seja, aqueles que estavam no nível da Expressão Linguística. Dos extraoracionais, selecionamos apenas constituintes que expressassassem duas funções retóricas: Orientação e Esclarecimento.

Delimitados os fatores que usamos em nossas análises, podemos agora revisitar nossos objetivos, como mostramos a seguir.

\section{Objetivos}

Objetivo geral

Como dissemos anteriormente, nosso objetivo mais amplo foi descrever e analisar, comparativamente, em PB e em EP, nas variedades presentes nos corpora escolhidos para esta pesquisa, e tendo como referencial teórico a GDF, descrever quais foram as estratégias de ordenação dos constituintes que expressam as funções pragmáticas (Tópico, Foco e Contraste) e duas das funções retóricas (Orientação e Esclarecimento).

\section{Objetivos específicos}

Dentre as especificidades investigadas, nossos objetivos foram descrever:

(ii) como os constituintes configuracionais de llocuções Declarativas, de EsCos dinâmicos, de construções Téticas e de construções Categoriais com Propriedades de um, dois ou três lugares e com funções pragmáticas de Foco, Tópico e Contraste se organizam em EP e em PB;

(iii) como se marcam, nessas duas línguas, as funções retóricas de Orientação e Esclarecimento, observando principalmente recursos de correferencialidade;

(iv) como ocorre, nessas duas línguas, a ordenação dos constituintes com funções pragmáticas em llocuções Interrogativas de Conteúdo e em respostas para llocuções Interrogativas Polares. 


\section{As hipóteses}

Como apontamos no capítulo 1, e retomamos aqui, as hipóteses ao início deste trabalho eram as seguintes:

1. Intuíamos que as duplicações em EP deveriam indicar alguma função discursiva, que ainda não sabíamos qual era (retórica ou pragmática) e que, portanto, era necessário defini-las.

2. Intuíamos também que essa função marcada pelas duplicações deveria ter um correspondente funcional em PB e que era necessário buscá-lo.

3. Sabendo já que o PB dispunha de posições fixas para alocar constituintes com as funções pragmáticas, sendo TOP ocupando $\mathrm{Pl}^{\mathrm{l}}$ e FOC ocupando $\mathrm{PF}^{\mathrm{F}}$, desejávamos ver se essa regularidade se aplicava ou não ao EP.

4. Supúnhamos que as respostas dadas às IPs em PB eram sintagmáticas, enquanto as do EP eram oracionais e com constituintes clíticos.

5. Supúnhamos, igualmente, que o PB tinha maior restrição para a ordenação de Sujeitos que o EP, já que parecia haver muito mais Sujeitos pospostos no EP que em $\mathrm{PB}$, mas não sabíamos as razões dessa diferença de ordenação, sendo, portanto, necessário averiguar quais sram essas razões.

6. Sabíamos que havia diferentes recursos nas duas línguas para destacar determinados constituintes (sem antes diferenciarmos as categorias de Foco, Contraste e Ênfase), como uso de que em EP, por exemplo. No entanto, ainda não conseguíamos sistematizar as semelhanças e diferenças nas duas línguas e era necessário percorrer esse caminho.

Notamos que as hipóteses iniciais eram bastante abrangentes, quase nada específicas. Muito do que se conclui neste trabalho, assim, foi se mostrando ao longo das análises como algo que não esperávamos. Vejamos agora em nossas considerações finais se tais hipóteses se confirmaram ou não, e quais outros dados, que nem supúnhamos encontrar inicialmente, se revelaram como pertinentes na comparação da ordenação nessas línguas. 


\section{CONSIDERAÇÕES FINAIS}

Para apresentar nossas considerações finais, retomaremos cada uma das hipóteses iniciais descritas anteriormente e acrescentaremos as conclusões a que chegamos para cada uma delas. Lembremos que todas estas conclusões por ora estão restritas aos dois corpora observados, nas duas variedades que eles contemplam e que novos estudos, com outras variedades, variantes, registros, contextos discursivos etc., serão necessários para que se possam fazer generalizações sobre essas línguas. Grande parte de todo o percurso que apresentamos e que retomamos aqui teve por base a proposta da existência de uma "inversa assimetria entre o PB e o E" (GONZÁLEZ, 1994), em função de peculiaridades de cada uma no âmbito do sistema pronominal e anafórico. Em sua tese, e em outros trabalhos posteriores, González observou essas questões a partir de um referencial teórico diferente do adotado nesta tese, e tinha por objetivo também explicar fenômenos que se verificavam no processo de aquisição/aprendizagem do $E$ por falantes adultos do PB, o que não está em foco neste trabalho. Esta tese corrobora muito do que já estava dito e intuído ali, mas amplia o quadro comparativo com a utilização de um novo referencial teórico, a GDF, que permite iluminar e oferecer novas e consistentes explicações aos casos aqui contemplados.

\section{Hipótese (1)}

Intuíamos que as duplicações, em EP, deveriam indicar alguma função discursiva, que ainda não sabíamos qual era (retórica ou pragmática) e que, portanto, era necessário defini-las.

\section{Conclusões}

As duplicações estão extremamente relacionadas à marcação de Tópico. Somente constituintes com função de Tópico podem ser duplicados. Como para a GDF o Tópico é uma função anafórica que resgata uma informação compartilhada pelos Interlocutores, seja no discurso enunciado, seja do contexto situacional ou ainda da memória episódica dos Interlocutores, ele nunca pode ser genérico/não especificado. Com base em estudos que já citamos ao longo dos capítulos, é sabido que as duplicações só ocorrem quando o clítico é correferencial a um constituinte 
[+específico], o que equivale a dizer que só ocorrem quando o clítico é correferencial a Tópicos. Por isso é que nomes nus, por exemplo, não são duplicados: ainda que esses nomes nus correspondam à função sintática de Sujeito, não correspondem à pragmática de Tópico. Por isso, também, constituintes focais não são duplicados.

As duplicações, portanto, têm motivação pragmática, o que não descarta, em absoluto, suas exigências semânticas [+específico]. Defendemos, portanto, que a motivação pragmática se sobrepõe à restrição semântica, o que condiz com a proposta da GDF de supremacia do Nível Interpessoal sobre o Nível Representacional e esse sobre o Nível Morfossintático. Lembremos: o Nível Interpessoal é o nível da pragmática, que no que descrevemos agora, tem relação com a intenção de resgatar uma informação, ou seja, de retomar um Tópico. O Nível Representacional é o da semântica, que no que descrevemos agora, tem relação com os traços de especificidade/determinação/genericidade). E que o Nível Morfossintático é onde acontecem as representações estruturais, cujos inputs foram recebidos dos níveis mais altos e do contexto. No que descrevemos agora, tem relação com a expressão linguística dos constituintes, com a presença do clítico e com a ordenação dos constituintes.

Concluímos, portanto, que as duplicações são uma das marcas linguísticas resultantes de como os Falantes organizam a cadeia informacional dos enunciados, com base em suas intenções comunicativas/pragmáticas.

\section{Hipótese (2)}

Intuíamos também que essa função marcada pelas duplicações deveria ter um correspondente funcional em PB e que era necessário buscá-lo.

\section{Conclusões}

Assim como em EP, no PB também só é possível duplicar Tópicos, pelos mesmos motivos explicados em (1). No entanto, aqui a assimetria entre essa língua e o EP se dá pelo tipo de constituinte que cada língua prefere topicalizar, ou seja, a qual constituinte cada língua prefere atribuir a função de Tópico. O espanhol tende a atribuir essa função pragmática a constituintes com função sintática de Objeto. Como os clíticos correspondem a complementos verbais, logicamente não podem ser correferentes a Sujeitos. Resta-Ihes ser, portanto, correferentes aos Objetos Tópicos. Quando há correferencialidade com os Sujeitos, o EP recorre à anáfora zero. A 
escolha pela anáfora zero reflete o alto grau de omissão desses constituintes Sujeitos na função de Tópico no espanhol. Essa não realização, que aqui estamos denominando não topicalização dos Sujeitos, e que está no Nível Interpessoal, se revela também em várias outras características estruturais do Nível Morfossintático, tais como uma maior frequência de ordenações VOS, VS e OVS; a alocação de constituintes $Q$ em $\mathrm{P}^{\mathrm{I}}$ de ICs; a exigência de respostas que expressem os Objetos nas respostas de IPs, etc.

Já o PB, em um mecanismo espelhado ao EP, tende a topicalizar os Sujeitos e a não topicalizar os Objetos. A topicalização dos Sujeitos se reflete na preferência de duplicação desses constituintes, e na não duplicação dos Objetos. Como Sujeitos não podem ser retomados por clíticos, como já dissemos, resta ao PB retomá-los por pronomes fortes. Disso advém, segundo nossa hipótese, a enorme diferença quantitativa entre esses tipos de pronomes nas duas línguas. Assim, independente do contexto ser formal ou informal, em EP abundam clíticos, enquanto os pronomes fortes são reservados para marcação de Sujeito Tópico/Foco Contrastivo. Em PB, os clíticos são quase que exclusivos de contextos formais, enquanto os pronomes fortes ganham tanto protagonismo nessa língua que são usados para marcar Sujeitos Tópicos, sem que eles precisem ser contrastivos. Daí a grande diferença quantitativa entre Sujeitos pronominais nas duas línguas, como mostramos em um dos gráficos: o PB apresentou mais que o dobro de emprego do pronome eu que o espanhol apresentou de yo, por exemplo. Foi grande também o uso de pronome forte para retomar/duplicar ou funcionar como Objetos, em sentenças tão usuais como $E u$ encontrei ela ou O Tommaso, ele tava vendo jogo, ainda que esses usos sejam condenados pela gramática normativa.

\section{Hipótese (3)}

Sabendo já que o PB dispunha de posições fixas para alocar constituintes com as funções pragmáticas, sendo TOP ocupando $\mathrm{PI}^{\prime}$ e FOC ocupando $\mathrm{PF}^{\mathrm{F}}$, desejávamos ver se essa regularidade se aplicava ou não ao EP.

\section{Conclusões}

No decorrer da pesquisa e com as análises dos dados, nossa hipótese inicial sobre, em PB, Tópico ocupar sempre $\mathrm{PI}^{\mathrm{e}}$ e Foco sempre ocupar $\mathrm{P}^{\mathrm{F}}$ mudou e concluímos que essas são apenas tendências. De fato, a ordenação informacional 
icônica do PB é TOP+comentário, com Tópico ocupando $\mathrm{P}^{\mathrm{I}}$ e, como dissemos em (1) e (2), sendo o Sujeito. Essa caracterização se reflete na predominância de uma ordem sintática SVO como a não marcada nessa língua, que se confirmou em nossas análises. Porém, mostramos que é muito comum também que os Falantes do PB aloquem constituintes tópicos em $\mathrm{PF}$, por exemplo, quando a intenção é colocar um elemento contrastivo em $\mathrm{Pl}$. Concluímos que topicidade e teticidade não são categorias vinculadas ao Molde de Predicação, como alguns pesquisadores defendem, argumentando que somente Propriedade Configuracional de predicação de zero e de um lugar podem expressar enunciados Téticos.

Em uma interpretação diferente dessa, defendemos que Tópico e Foco não dependem de fatores sintáticos nem semânticos, mas sim, pragmáticos e contextuais. Um mesmo enunciado pode ser interpretado como Categórico em um contexto e Tético em outro, a depender do grau de novidade da informação apresentada. Essa interpretação, portanto, é contrária a de que só sentenças com ordem VS podem ser Téticas no PB.

Essas mesmas noções de topicidade e teticidade se aplicam ao EP, porém, cada língua tem diferentes preferências para selecionar quais constituintes carregarão essas funções pragmáticas, bem como dispõe de estratégias variadas para expressálas. Como já dissemos, enquanto o PB tende a topicalizar Sujeitos, o EP tende a topicalizar Objetos, alocando-os também em Pl. Podemos dizer, assim, que o EP também é uma língua do tipo Tópico-comentário, mas com ordenações não marcadas diferentes de SVO.

Pensar na forma de organização dos constituintes tópicos em espanhol e suas chamadas duplicações nos conduziu a propor uma gradualidade de pragmatismo dos constituintes. Nossa proposta é que constituintes mais pragmáticos, devido ao fato de carregarem, simultaneamente, mais de uma função (nos casos analisados, Tópico e Contraste), ocupem posições absolutas de $\mathrm{Pl}^{\mathrm{l}}$ e $\mathrm{PF}$, e que constituintes menos pragmáticos, ou seja, os que carregam apenas uma função, se localizem nas posições relativas de $\mathrm{Pl}^{\mathrm{I}} \mathrm{e} \mathrm{P}$. A mesma proposta de gradualidade nos serviu para explicar uma questão que há muito nos intrigava e para a qual nunca havíamos encontrado uma resposta. Questão, aliás, que foi o gatilho para a presente pesquisa: a expressão de um Sujeito posposto quase que obrigatório (se não obrigatório) em llocuções Interrogativas de Conteúdo. 
Por isso, retomamos aqui a tal sentença provocadora, que apresentamos logo no início da Introdução deste trabalho: ¿A quién ha visto Juan?

$\mathrm{Na}$ Introdução, relatamos que esse tipo de sentença gerava dificuldades de interpretação em alunos brasileiros, que costumam entender o constituinte alocado depois do predicado como sendo o Objeto, ou seja, o Inativo, já que em PB, como vimos, as funções semânticas são determinantes para a ordenação. Em PB, em sentenças de EsCos [+din] e de propriedade Configuracional de dois lugares, como é o caso do exemplo dado, Ator sempre se posiciona à esquerda de $\mathrm{PM}^{\mathrm{M}}$, enquanto Inativos e Locativos, à sua direita. Assim, os alunos brasileiros, aprendizes de ELE tendem a reproduzir em EP a interpretação da estrutura do PB. A única resposta que tínhamos para essa questão antes de desenvolvermos esta pesquisa era a de que em E é muito frequente que Sujeitos se posicionem no final das sentenças, devido à maior liberdade de ordenação de que essa língua dispõe, dada a possibilidade de distinguir Sujeitos de Objetos (na época nem conhecíamos as noções da GDF de Ator/Inativo/Locativo), por meio do uso da preposição a para indicar determinados Objetos, particularmente o direto. Essa explicação não perde em nada seu valor de verdade. Mas é insuficiente, do nosso ponto de vista, para explicar a alta frequência de Sujeitos pospostos, que ora pareciam opcionais e motivados por questões estilísticas, ora pareciam obrigatórios (como no caso das sentenças Interrogativas). Todo nosso percurso investigativo nos mostrou, no entanto, que a posposição do Sujeito em $\mathrm{E}$ tem motivação pragmática: não está restrita ao tipo de predicado, como mostramos em um dos nossos gráficos, em que estruturas com Sujeito posposto apareceram combinadas com 51 verbos diferentes. Isso exclui totalmente a hipótese de que em EP ocorra algo como ocorre em PB, em que a ordenação é menos flexível justamente pela falta de marcas morfossintáticas que permitam diferenciar Ator/Inativo.

Assim, em PB, vimos que a ordem VS está altamente restrita à Propriedade Configuracional e aos verbos acusativos e dicendi, por razões históricas da língua que geraram as mudanças pelas quais ela passou, exaustivamente descritas em inúmeros trabalhos. Parece-nos, assim, que a alta incidência de Sujeitos pospostos no EP é motivada pragmaticamente: como a $\mathrm{P}^{\mathrm{I}}$ normalmente é ocupada por Tópicos Objetos e os Sujeitos tendem a ser omitidos, a expressão do Sujeito em EP tem majoritariamente (não exclusivamente) propósitos contrastivos. Como, nas ICs, a $\mathrm{P}^{\mathrm{I}}$ está ocupada pelo constituinte $Q$, a forma não contrastiva dos enunciados é $Q$ (Foco) + Sujeito Tópico 
nulo + predicado. Se, no entanto, o Sujeito Tópico carregar simultaneamente a função de Contraste (e aqui incluímos nesse grupo todas as formas desambiguadoras de terceiras pessoas), ele deverá ser expresso e ocupar uma posição de sobressalência pragmática, ou seja, posição absoluta de $\mathrm{PF}$. Isso explica a questão inicial deste trabalho. Agora pensamos, então, conseguir responder aos alunos por que o Juan aparece lá no final da sentença.

Quanto à focalização de constituintes, cada língua também dispõe de estratégias que ora se assemelham, ora são muito peculiares de cada uma. As estratégias sempre dependem da função sintática do elemento que se quer focalizar. Assim, para focalizar Objetos, o EP pode alocá-los em $\mathrm{P}^{\mathrm{l}}$ e não retomá-los por clítico, enquanto o PB dispõe da estratégia de Foco-ser. Uma estratégia para marcação de Foco disponível nas duas línguas é alocar em $\mathrm{PF}^{\mathrm{F}}$ um constituinte que normalmente não ocuparia tal posição, como, por exemplo, um complemento verbal sem função pragmática, que normalmente ocuparia domínio de $\mathrm{P}^{\mathrm{M}}$. Ambas as línguas também dispõem da estratégia dos nomes nus para construir sentenças inteiramente focais, porém, as restrições de usos para considerar genericidade/especificidade/determinação podem diferir bastante entre o PB e o EP. Em outras palavras, como mostramos no decorrer do trabalho, a partir do estudo de González (2014), as duas línguas possuem e diferenciam nomes genéricos de específicos, mas o uso de genéricos, por exemplo, através de nomes nus, não tem muitas restrições de usos do PB para expressar sentenças tidas como verdades universais (como mãe é tudo igual), e é muito mais restrita no EP, que as reserva bastante para o rito de refrãos, como perro que ladra no muerde. Além disso, o EP ainda se vale dos usos de dativos para, mais uma vez, não topicalizar seus Sujeitos.

Ainda sobre os enunciados Categóricos e Téticos nas duas línguas, e com base nos Sujeitos Tópicos /e ou Contrastivos pospostos, nós propusemos a existência de uma categoria intermediária: os enunciados semi-Téticos. Esses enunciados são apresentativos/descritivos de EsCos e não têm por objetivo declarar algo sobre um Tópico. Não se trata, portanto, se sentenças episódicas. No entanto, não achamos que podem ser consideradas completamente Téticas, uma vez que abrigam um constituinte especificado/determinado e que correspondem a um elemento conhecido pelos participantes da interlocução. No entanto, como dissemos, o propósito da sentença não é predicar nada sobre eles. Tampouco são Inativos ou Locativos/Objetos. São, portanto, Sujeitos semi-tópicos. 


\section{Hipótese (4)}

Supúnhamos que as respostas dadas às IPs em PB eram sintagmáticas, enquanto as do EP eram oracionais e com constituintes clíticos.

\section{Conclusões}

Essa hipótese foi confirmada pelos nossos dados, que nos mostraram que em PB as respostas tendem a ser constituídas somente pelo verbo da pergunta, com atualização número-pessoal. Há, portanto, forte preferência por Objetos nulos ou, quando expressos lexicamente, recorre-se aos pronomes fortes. Isso evidencia nossa tese de que o PB esteja em um processo de não topicalizar seus Objetos. O EP, assimetricamente, sempre realiza seus Objetos, e sempre por clíticos, já que os pronomes fortes são reservados para indicação de Sujeito contrastivo.

\section{Hipótese (5)}

Supúnhamos, igualmente, que o PB tinha maior restrição para a ordenação de Sujeitos que o EP, já que parecia haver muito mais Sujeitos pospostos no EP que em PB, mas não sabíamos as razões dessa diferença de ordenação, sendo, portanto, necessário averiguar quais eram elas.

\section{Conclusões}

Deixamos de explicitá-las aqui porque consideramos que já foram explicitadas nas conclusões das hipóteses anteriores, evitamos assim, repetições desnecessárias.

\section{Hipótese (6)}

Sabíamos que havia diferentes recursos nas duas línguas para destacar determinados constituintes (sem antes diferenciarmos as categorias de Foco, Contraste e Ênfase), como uso de que em EP, por exemplo. No entanto, ainda não conseguíamos sistematizar as semelhanças e diferenças nas duas línguas e era necessário percorrer esse caminho.

\section{Conclusões}

Muito do que se explicaria aqui também já foi explicado pelas conclusões das hipóteses anteriores. Faltou dizer, porém, que a Ênfase é obtida por meio de operadores e que é uma categoria distinta de Foco, embora ambas sejam categorias 
para salientar determinados constituintes. Dentre os operadores enfáticos usados nas duas línguas, vimos o uso de que / es que. Um rápido teste de aceitabilidade que aplicamos com hispanoparlantes revelou que o EP tem muito mais restrições para o uso de operadores de Ênfase escopando operadores de llocução Interrogativa que o PB.

Para expressar Contraste, as duas línguas dispõem de estruturas clivadas, das quais falamos muito rapidamente por não comporem nossos objetivos de pesquisa. Além disso, como falamos anteriormente, várias composições contrastivas podem ser obtidas através do posicionamento dos constituintes, e que tanto Tópicos como Focos podem ser contrastados. Como também já demonstramos, o uso de Sujeitos lexicais/pronominais em EP carrega quase sempre um traço constrastivo, enquanto no PB não necessariamente.

\section{O FINAL DO FINAL}

Encerramos este trabalho conscientes de que há muito a ser feito ainda no estudo da ordenação dos constituintes e que certamente inúmeras questões altamente relevantes para sua compreensão não foram abordadas aqui ou foram, mas de maneira extremamente superficial, devido às limitações de tempo e espaço. Este trabalho, assim, deixa pendentes questões de ordenação de constituintes hierárquicos, como operadores e modificadores de diferentes tipos; ordenações de sentenças complexas, em seus diferentes tipos; de sentenças com EsCos [-din], etc. Segundo nosso ponto de vista, um estudo da marcação prosódica seria essencial para complementar o apresentado aqui, principalmente para diferenciar as funções de Orientação e Esclarecimento.

No entanto, com todas as deficiências, acreditamos ter alcançado nossos objetivos neste trabalho e que a perspectiva teórica que adotamos nos possibilitou encontrar respostas para várias indagações e a perceber que ordens aparentemente iguais podem revelar funcionalidades muito diferentes, e que, por isso, um estudo da ordenação que não tome por base apenas os fatores sintáticos e semânticos, como se costuma fazer, mas sim pragmáticos, parece ser um caminho profícuo para futuras pesquisas.

No que se refere à comparação entre o PB e o EP, parece-nos primordial que muitas conclusões e hipóteses aqui apresentadas sejam estudadas considerando-se 
outras variedades, variantes, registros, modalidades etc. de ambas as línguas. Embora nosso estudo tenha se restringido a apenas uma ínfima amostra da diversidade desses idiomas, acreditamos que conseguimos traçar muitos paralelos, mostrando algumas semelhanças, mas priorizando as diferenças. Terminamos, portanto, com a sensação de termos contribuído com os estudos contrastivos, mostrando, principalmente, mais uma inversa assimetria entre as lenguas hermanas, já que quase todos os resultados que apresentamos aqui se explicam e justificam pelo espelhamento de preferências dessas duas línguas quanto à atribuição da função Tópico: assimetricamente, o PB tende a topicalizar seus Sujeitos e a não topicalizar seus Objetos, enquanto o EP tende a topicalizar seus Objetos e a não topicalizar seus Sujeitos. Acreditamos que essa assimetria explique e reúna em um só rótulo muitas outras assimetrias já descritas. 


\section{REFERÊNCIAS BIBLIOGRÁFICAS E BIBLIOGRAFIA CONSULTADA}

ADAM, J. M. A linguística textual: introdução à análise textual dos discursos. São Paulo: Cortez, 2008.

ALVES-SILVA, J. J. Os pronomes pessoais em português: uma análise à luz da linguística sistêmico-funcional. Domínios de Lingu@agem, Uberlândia, v. 3, n. 1, p. 90-113, 2009.

ANDRADE, C. A. B. de.; MICHELETTI, G.; SEARA, I. R. Memória, discurso e tecnologia. São Paulo: Terracota Editora, 2016.

ASSUNÇÃO, D. M. F. Posição variável do sujeito no falar maranhense. 2014. Tese (Doutorado em Linguística) - Faculdade de Letras, Universidade Federal do Rio de Janeiro, Rio de Janeiro, 2014.

ARAÚJO JUNIOR, B. J. As passivas na produção escrita de brasileiros aprendizes de Espanhol como língua estrangeira. 2007. Dissertação (Mestrado em Língua Espanhola e Literaturas Espanhola e Hispano-Americana) - Faculdade de Filosofia, Letras e Ciências Humanas, Universidade de São Paulo, São Paulo, 2007.

Limites precisos ou fronteiras que desaparecem? As construções impessoais e passivas com o clítico SE/SE no português brasileiro e no espanhol. 2013. Tese (Doutorado em Língua Espanhola e Literaturas Espanhola e Hispano-Americana) - Faculdade de Filosofia, Letras e Ciências Humanas, Universidade de São Paulo, São Paulo, 2013.

BAGNO, M. Gramática Pedagógica do Português Brasileiro. São Paulo: Parábola, 2012.

BAKHTIN, M. Estética da criação verbal. 4. ed. São Paulo. Martins Fontes, 2003.

BEAUGRANDE, R. Functionality and Textuality. Wien: Universitáts Verlag, 1993.

BERLINCK, R. A. A construção VSN no português brasileiro: uma visão diacrônica do fenômeno da ordem. Campinas: Pontes, 1989.

BRAGA, M L. Construções clivadas no português do Brasil sob uma abordagem funcionalista. Matraga, Rio de Janeiro, v. 16, n. 24, p.173-196, jan./jun. 2009.

CANAES E MARIZ DE PÁDUA, M.P. A ordem das palavras no português arcaico: (frases de verbo transitivo). Coimbra: Instituto de Estudos Românicos, Faculdade de Letras da Universidade de Coimbra, 1960.

CASTILHO, A. T. Nova gramática do português brasileiro. São Paulo: Contexto, 2014.

CHAFE, W. Givenness, contrastiveness, definiteness, subjects and topics. In: C. N. Li, Subject and topic, New York: Academic Press: 26-55, 1976. 
Identificability and 'Definiteness'. In: . Discourse, Consciousness, and Time. Chicago: The University of Chicago Press, 1994.

CINTRA, M. R. A relação entre a posição, a forma de manifestação e a funcionalidade pragmática dos complementos adverbiais. In: PEZATTI, E. G. (Org.). Pesquisas em Gramática funcional - Descrição do Português. São Paulo: Ed. UNESP, 2009.

COMPARINI, A. M. P.; GUIRALDELLI, L. A.; SOUZA, E. R. F. Referência cruzada e concordância oracional no estudo de transparência e opacidade em línguas indígenas do Brasil. LIAMES: língua indígenas americanas, Campinas, v. 17, n. 2, p. 307-340, jul./dez. 2017.

CONNOLLY, J. H. Context in Functional Discourse Grammar. Alfa: revista de Linguística, São Paulo, v. 51, n. 2, p. 11-33, 2007.

CONTRERAS, H. El orden de palabras en español. Madrid: Ediciones Cátedra, 1978.

CUNHA, C.; CINTRA, L. F. L. Nova gramática do português contemporâneo. 2 ed. Rio de Janeiro: Nova fronteira, 1985.

DECAT, M. B. N. Construções de tópico em português: uma abordagem diacrônica à luz do encaixamento no sistema pronominal. Campinas: Pontes, 1989.

DIB, A. V.; CORREA, P. P. A função pragmática Tópico na legendagem brasileira de um filme argentino em um estudo de corpus paralelo. Revista Letras \& Letras. v. 30, n. 2, p. 139-155, 2014.

DIK, S. Functional Grammar. Dordrecht/Cinnaminson: Foris Publications, 1981.

. The Theory of Functional Grammar. Parte I: Dordrecht/Cinnaminson: Foris Publications, 1989. 1997.

The theory of Functional Grammar. Berlim/Nova York: Monton de Gruyter,

DRYER, M. S. The Greenbergian Word Order Correlations. Language. v. 68, n. 1, p. 81-138, 1992. Disponível em:

http://linguistics.buffalo.edu/people/faculty/dryer/dryer/wordOrder.htm. Acesso em: 13 abr. 2016.

FANJUL, A. P. Conhecendo assimetrias: a ocorrência de pronomes pessoais. In: FANJUL, A. \& GONZÁLEZ, N. M. Espanhol e português brasileiro: estudos comparados. São Paulo: Parábola, 2014, p. 29-50.

FERNÁNDEZ SORIANO, O. Sobre el orden de palabras en español. DICE/VDA. Cuadernas de Filología Hispánica, n. II, 113-152. Madrid: Edit. Complutense. 1993.

FIRBAS, J. Non-thematic subjects in contemporany English. Travaux Linguistiques de Prague, v. 2, p. 239-256, 1966. 
FONTES, M. G. A distinção léxico-gramática na gramática discursivo-funcional: uma proposta de implementação. 2016. Tese (Doutorado em Estudos Linguísticos) Universidade Estadual Paulista “Júlio Mesquita Filho", São José do Rio Preto, 2016.

. Abordagem hierárquica da gramaticalização de construções clivadas em interrogativas de conteúdo. Revista do GEL, São Paulo, v. 15, n. 1, p. 10-37, 2018.

GALVÃO, V. C. Gramática discursivo-funcional e teoria da gramaticalização: revisando os usos de (diski) no português brasileiro. Filologia Linguística Portuguesa, São Paulo, v. 13, n. 2, p. 305-335, 2011.

GANCEDO ÁLVAREZ, M. A. La oblicuidad, construções de dativos na interlíngua de estudantes brasileiros de espanhol. 2002. Dissertação (Mestrado em Língua Espanhola e Literaturas Espanhola e Hispano-Americana) - Faculdade de Filosofia, Letras e Ciências Humanas, Universidade de São Paulo, São Paulo, 2002.

GASPARINI-BASTOS, S. D. Os constituintes extrafrasais com valor epistêmico: análises de entrevistas jornalísticas no espanhol e no português. 2004. 161 f. Tese (Doutorado em Linguística e Língua Portuguesa), Universidade Estadual Paulista, Araraquara, 2004.

As construções de polaridade positiva e negativa como constituintes extrafrasais. Estudos Lingüísticos XXXIV, São Paulo, v. 1, n. 34, p. 439-444, 2005.

Construções de foco em português e espanhol sob a perspectiva da Gramática Discursivo-funcional. Estudos Lingüísticos, São Paulo, v. 37, n. 1, p. 253258, jan./abr. 2008.

GIVÓN, T. Syntax: a functional-typological introduction. Volume I. Amsterdam: John Benjamins, 1984.

. A compreensão da gramática. Tradução: Maria Angélica Furtado da Cunha, Mário Eduardo Martelotta, Filipe Albani. São Paulo: Cortez; EDUFRN, 2012.

GÓMES, A; MARCO, M. A. Estado actual de los corpus de lengua española hablada y escrita: I+D. El español en el mundo. Anuario del Instituto Cervantes, 2009. Disponível em <https://cvc.cervantes.es/lengua/anuario/anuario_09/briz_albeida/p02.htm\#np5>.

Acesso em: 10 mai 2016.

GONZÁLEZ, N. T. M. Cadê o pronome? - O gato comeu. Os pronomes pessoais na aquisição/aprendizagem do espanhol por brasileiros adultos. Tese (Doutorado em Semiótica e Lingüística Geral) - Faculdade de Filosofia, Letras e Ciências Humanas, Universidade de São Paulo, São Paulo, 1994.

- ¿Pero qué gramática es ésta? Los sujetos pronominales y los clíticos en la interlengua de brasileños adultos aprendices de Español/LE. Revista Rilce Filología Hispánica, Pamplona, Espanha, v. 14, n.2, p. 243-263, 1998. 
GONZÁLEZ, N. T. M.; KULIKOWSKI, M. Z. Español para brasileños. Sobre por dónde determinar la justa medida de una cercanía. Anuario Brasileño de Estudios Hispánicos, Brasília-DF, v. 9, p. 11-19, 1999.

- Quantas caras tem a transferência? Os clíticos no processo de aquisição/aprendizagem do Espanhol/Língua Estrangeira. In: BRUNO, F. C (Org.). Ensino-Aprendizagem de línguas estrangeiras: reflexão e prática. São Carlos: Claraluz, 2005, p. 53-70.

Portugués brasileño y español: lenguas inversamente asimétricas. In: CELADA, M. T.; GONZÁLEZ, N. M. (Coord.). Dossier: Gestos que trazan distinciones entre la lengua española y el portugués brasileño. SIGNOS ELE, Buenos Aires: Universidad del Salvador, dez. 2008.

. A ausência de determinante: referência genérica vs. referência específica. In: FANJUL, A \& GONZÁLEZ, N. M. Espanhol e português brasileiro: estudos comparados. São Paulo: Parábola, 2014, p. 113-129.

GONZÁlEZ, N. T. M.; CELADA, M. T. Los estudios de lengua española en Brasil. Anuario Brasileño de Estudios Hispánicos. Brasília; Madrid, v. 2, p. 35-58, 2000.

. El contrapunto de dos lenguas: los argentinos somo así/ brasileiro é assim mesmo. Revista de Profesores, Espanha, 2001.

GREENBERG, J. H. Universals of Language. Cambridge: The MIT Press, 1966.

GROPPI, M. Falando de Pronomes. Signum: Estudos Linguísticos, Londrina, v. 9, n. 1, p. 95-110, jun. 2006.

Duplicaciones pronominales síntesis de puntos clave. Signos ELE: Revista de Español como Lengua Extranjera, Argentina, n. extra 1-2, (Ejemplar dedicado a: 2007/2008).

. El objeto indirecto: síntesis de puntos clave. In: CELADA, M. T. y N. MAIA GONZÁLEZ (coord. dossier). Gestos que trazan distinciones entre la lengua española y el portugués brasileño, SIGNOS ELE, $n^{\circ}$ 1-2. Buenos Aires: Universidad del Salvador, dez. 2008.

Hablar... hacer. ¿Qué hacemos cuando usamos las formas pronominales? In: GONZÁLEZ, N. M. \& M. T. CELADA (coord. dossier). - Interlocuciones entre el campo de los estudios del lenguaje y el de la formación de profesoresll Signos ELE: Revista de Español como Lengua Extranjera, Universidad del Salvador, Buenos Aires, dez. 2015. Disponível em: <http://p3.usal.edu.ar/index.php/ele/article/view/3445>. Acesso em: 13 mar 2017.

GROPPI, M.; ZORZO-VELOSO, F. El fenómeno de la duplicación en las estructuras de clíticos en el español y la vehiculación de la información. Actas Instituto Cervantes, Rio de Janeiro, p. 259-264, 2004. Trabalho apresentado no Simpósio de Didáctica de Español para Extranjeros: teoría y práctica, 2004. 
GUTIÉRREZ ORDOÑEZ, S. Temas, remas, focos, tópicos y comentários. 3. ed. Madrid: Arco Libros, 1997.

HALLIDAY, M. A.K. Estructura y función del lenguaje. In: LYONS, J. (Org.). Nuevos horizontes de la lingüística. Madrid: Alianza Editorial, 1975, p. 145-173.

HATCHER, A. G. Theme and underlying question. Two studies of Spanish word order. Word, Nova York, v. 12, suplemento n. 3, 1956.

HENGEVELD, K.; MACKENZIE, J. L. Functional discourse grammar: a typologically - based theory of language structure. Oxford: Oxford University press, 2008.

. Alinhamento Interpessoal, Representacional e Morfossintático na Gramática Discursivo-Funcional. Revista Delta, São Paulo, v. 25, n.1, p. 181-208, 2009.

HERNANZ, M. L.; BRUCART, J. M. La sintaxis. Principios teóricos. La oración simple. Crítica, Barcelona, v.1, 1987.

HOPPER, P. Emergent Grammar. Berkeley Linguistic Society. v. 13, p. 139-157, 1987.

ILARI, R. Sobre os advérbios focalizadores. In: ILARI, R. et al. Gramática do português falado. Campinas: Editora da Unicamp, FAPESP, 1992, p. 193-212.

KATO, M. A.; RAPOSO, E. Europen and Brazilian Portuguese word order: questions, focus and topic constructions. Aspects of Romance Linguistics. 1996. Disponível em: http://www.unicamp.br/iel/romanianova/artigos/CLsrl1996.pdf. >. Acesso em: 18 fev 2018.

KATO, M. A. A natureza do objeto nulo e do nome nulo no Português Europeu e no Português Brasileiro. Revista Intercâmbio, v. 23: 13-27, 2011. São Paulo: LAEL/PUCSP.

KUNO, S. Functional Syntax: Anaphora, Discourse, and Empathy. Chicago: University of Chicago Press, 1987.

LAMBRECHT, K. Information Structure and Sentence Form. Topic, Focus and the Mental Representation of Discourse Referents. Cambridge, Cambridge University Press, 1994. Disponível em: <http://dx.doi.org/10.1017/CBO9780511620607>. Acesso em: 18 fev 2018.

2006.

A framework for the analysis of cleft constructions. Linguistics, vol 39, $<$ https://www.degruyter.com/view/j/ling.2001.39.issue-

3/ling.2001.021/ling.2001.021.xml>. Acesso em: 14 jun 2017.

LEHMANN, W. Syntactic typology. Austin: University of Texas Press, 1978.

LIMA-HERNANDES, M. O princípio da iconicidade e sua atuação no português do Brasil. Filologia e Linguística Portuguesa, São Paulo, n. 8, p. 83-96, 2006. 
LOPES, M. G. Encapsulamentos semânticos em perspectiva discursivofuncional. 2010. 219 f. Dissertação (Mestrado em Letras), Universidade Federal Fluminense, Niterói, 2010.

LOPES ROSSI, M. A. G. Estudo diacrônico sobre as interrogativas do português do Brasil. In: ROBERTS, I.; KATO, M. A (Org.). Português Brasileiro: uma viagem diacrônica. Campinas: Editora da Unicamp, 1993, p. 307-342.

LYONS, C. Definiteness. Cambridge: Cambridge University Press, 1999.

MARCUSCHI, L. A. Gêneros textuais: definição e funcionalidade. In: DIONÍSIO, A. P.; MACHADO, A. R.; BEZERRA, M. (Org.) Gêneros Textuais e ensino. 3. ed. Rio de Janeiro: Lucerna, 2005, p. 19-36.

MARQUES, P. M. Estudo diacrônico da ordenação do sujeito em relação ao verbo no português. 2012. Tese (Doutorado em Linguística) - Faculdade de Letras, Universidade Federal do Rio de Janeiro, Rio de Janeiro, 2012.

MARTINET, A. Elementos de lingüística geral. Lisboa: Sá da Costa, 1972.

MARTINS, N. R. S. P; BORGES, R.S. A semântica dos nomes nus no português brasileiro falado em Teresina- PI. Revista Digital do Programa de Pós-Graduação da PUCRS, Porto Alegre, v. 8, n. 2, p. 454-466, jul-dez 2015.

MESQUITA, R. M. Gramática da Língua Portuguesa. 8. ed. São Paulo: Saraiva, 1999.

MIOTO, C. Focalização e quantificação. Revista Letras, Curitiba, v. 61, p. 169-189, 2004.

MIRANDA, W. Kel e a expressão de definitude em caboverdiano. Revista de Estudos da Linguagem, Belo Horizonte, v. 23, n. 2, p. 425-450, sep. 2015.

NAGAMURA, G. H. A expressão da subjetividade na Gramática DiscursivoFuncional. 2016. Tese (Doutorado em Estudos Linguísticos) - Universidade Estadual Paulista "Júlio de Mesquita Filho", São José do Rio Preto, 2016.

NEVES, M. H. M. A gramática funcional. São Paulo, Martins Fontes, 2001.

NOGUEIRA, M. G. A ordenação dos advérbios em -mente no Português falado do Brasil. In.: PEZATTI, E. G. (Org.). Pesquisas em Gramática funcional - Descrição do Português. São Paulo: UNESP, 2009, p.83-107.

OLIVEIRA, R. C. Sintaxe Tipológica. In: OTHERO, G. A; KENEDY, E. (Org.) Sintaxe, Sintaxes: uma introdução. São Paulo: Contexto, 2015, p. 85-102.

PADILLA GARCÍA, X. El orden de palabras en el español coloquial. 2001. Tesis (doctoral). Facultad de Filología, Departamento de Filología Española, Universitat de València, Valencia, 2001. 
PEZATTI, E, G. A ordem de palavras em português: aspectos tipológicos e funcionais. 1992. Tese (Doutorado em Linguística e Língua Portuguesa) - Faculdade de Ciências e Letras, Universidade Estadual Paulista "Júlio de Mesquita Filho", Araraquara, 1992.

. Uma Abordagem Funcionalista da Ordem de Palavras no Português Falado. Alfa: Revista de Linguística, São Paulo, v. 38, p. 37-56, 1994.

Constituintes pragmáticos em posição inicial: distinção entre tema, tópico e foco. Alfa: Revista de Linguística, São Paulo, v. 42, p.133-150, 1998 (a).

Os constituintes pragmáticos intra e extra-oracionais: foco, tema, atitema. Estudos Linguísticos, São Paulo, v. 27, p. 212-217, 1998 (b).

. O funcionalismo em linguística. In: MUSSALIM, F.; BENTES, A. C. (Orgs). Introdução à linguística: fundamentos epistemológicos. São Paulo: Cortez, 2005, p. 165-218.

PEZATTI, E. G.; FONTES, M. G. As interrogativas de conteúdo nas variedades do português falado. Revista do Gel, São Paulo, v. 7, n. 2, p. 171-197, 2010.

Clivagem e construções similares: contraste, foco e ênfase. Linguagem, Montevidéu, v. 28, p. 73-98, 2012 (a).

Ordenação de constituintes em construções categorial, tética e apresentativa. D.E.L.T.A., São Paulo, v. 28, n. 2, p. 353-385, 2012(b).

. A ordem das palavras no português. São Paulo: Parábola Editorial, 2014.

- Ordenação de constituintes em sentenças declarativas do português brasileiro. Veredas online, Juiz de Fora, 2011, p. 206-221. Disponível em <http://www.ufjf.br/revistaveredas/files/2011/05/ARTIGO-151.pdf>. Acesso em: 10 set 2016.

. O Contexto na Gramática Discursivo-Funcional. CIELLI/MARINGÁ, 2010. Mesa-redonda: relações entre questões textual-discursivas e expressão morfossintática na gramática (discursivo)-funcional. Disponível em <http://www.dle.uem.br/funcpar/pezatti_cielli_2010.pdf>. Acesso em: 02 dez 2017.

. Motivações discursivas na ordem dos constituintes em Português: a função pragmática Contraste. Texto no prelo enviado pela autora.

PEZATTI, E. G.; CAMACHO, R.G. Funções retóricas e ordem: relação entre pragmática e morfossintaxe. In: OLIVEIRA, M.R; CEZARIO, M. M (Org.). Funcionalismo linguístico - Diálogos e vertentes. Rio de Janeiro, Eduff, 2017, p. 157-184. 
PILATI, E. Sobre a ordem verbo-sujeito no Português Brasileiro: 30 anos em mirada crítica. Revista Linguística, Rio de Janeiro, p. 183-205. v. 2, n. 2. dez. 2016.

PINHEIRO-CORREA, P. Características das construções de foco sentencial no português, em um estudo de corpus paralelo. ReVEL, edição especial, n. 10, p. 195222, 2015.2 Disponível em: <http://revel.inf.br/files/dd41a848c2c35d35acbfa20aa99b5765.pdf>. Acesso em 19 fev 2018.

A forma das sentenças téticas anunciativas no português do Brasil. SCRIPTA, Belo Horizonte, v. 22, n. 44, p. 233-248, $1^{\circ}$ quadrimestre de 2018.

PINTO, C.F.C. Uma análise das construções de clivagem e outras construções focalizadoras do espanhol atual. 2008. Dissertação (Mestrado em Letras e Linguística), Universidade Federal da Bahia, Salvador, 2008.

PINTO, C. F; RIBEIRO, I. Um estudo sintático-discursivo comparativo da clivagem em línguas românicas. In: MOURA, D. (Org). Os desafios da língua: estudos em língua falada e escrita. Maceió: EDUFAL, p. 401-404, 2008.

PONTES, E. O tópico no português do Brasil. Campinas: Pontes, 1987.

ROSÁRIO, I. Sintaxe Funcional. In: Sintaxe, sintaxes - uma introdução. São Paulo: Contexto, 2015, p. 143-161.

SANTOS, O. F. Sobre o parâmetro do sujeito nulo: interferência do português brasileiro no espanhol falado por nativos residentes no Brasil. 2013. Dissertação (Mestrado em Letras), Universidade Federal de Pernambuco, Recife, 2013.

SASSE, H. J. (2006). Theticity. In Bernini, G.; Schwarz, M.L. (eds.). Pragmatic organization of discourse in the languages of Europe. Berlin: Mouton de Gruyter. SORNICOLA, R. (1995). Theticity, VS order and the interplay of syntax, semantics and pragmatics. Sprach typologie und Universal ienforschung, 48.

SILVA, J. Q. G. Gênero discursivo e tipo textual. Scripta, Belo Horizonte, v. 2, n. 4, p. 87- 106, 1999.

SOUZA, C. N. de. Gramática discursivo-funcional, gramaticalização e modalização. Revista de Estudos da Linguagem, Belo Horizonte, v. 25, n. 4, p. 2095-2126, 2017.

SOUZA, E. R. F. Os advérbios focalizadores no português falado do Brasil: uma abordagem funcionalista. 2004. Dissertação (Mestrado em Estudos Linguísticos) Instituto de Biociências, Letras e Ciências Exatas, Universidade Estadual Paulista, São Paulo, 2004.

Gramaticalização dos itens linguísticos assim, já e aí no português brasileiro: um estudo sob a perspectiva da gramatica discursivo-funcional. 2009. Tese (Doutorado em Linguística) - Instituto de Estudos da Linguagem, Universidade Estadual de Campinas, Campinas, 2009. 
Funcionalismo linguístico: novas tendências teóricas. São Paulo: Editora Contexto, 2012.

SPÓSITO, C. C. Construções de causa, razão, explicação e motivação na lusofonia: uma abordagem discursivo-funcional. 2012. Dissertação (Mestrado em Estudos Linguísticos) - Instituto de Biociências, Letras e Ciências Exatas, Universidade Estadual Paulista, São Paulo, 2012.

STIEHM, B. Spanish word order in non-sentence construction. Language, 51, p. 4988, 1975.

TARALLO, F. et al. Rupturas na ordem de adjacência canônica no português falado. In: CASTILHO, A. T. (Org.) Gramática do Português Falado. v. 1: A Ordem. Campinas, SP: Editora de UNICAMP/FAPESP, 2002. p. 29-62.

THOMPSON, S.; MANN, W. Antithesis: A Study in Clause Combining and Discourse Structure. University of Southern California, 1987. Disponível em: <http://www.sfu.ca/rst/05bibliographies/bibs/ISI_RS_87_171.pdf>. Acesso em: 20 abr 2016.

YOKOTA, R. O que eu falo não se escreve. E o que eu escrevo alguém fala?: $A$ variabilidade no uso do objeto anafórico na produção oral e escrita de aprendizes brasileiros de espanhol. 2007. Tese (Doutorado em Língua Espanhola e Literaturas Espanhola e Hispano-Americana) - Faculdade de Filosofia, Letras e Ciências Humanas, Universidade de São Paulo, São Paulo, 2007.

ZORZO-VELOSO, V. F. O fenômeno da duplicação em estruturas de clíticos no Espanhol e a veiculação da informação. 2003. Dissertação (Mestrado em Língua Espanhola e Literatura Espanhola e Hispano-Americana) - Faculdade de Filosofia, Letras e Ciências Humanas, Universidade Federal São Paulo, São Paulo, 2003.

ZUBIZARRETA, M. L. Prosody, Focus, and Word Order. Cambridge, MA: MIT Press, 1998.

\section{CORPORA UTILIZADOS OU CONSULTADOS}

C-ORAL-BRASIL. Disponível em: <http://www.c-oral-brasil.org/>. Acesso em: 28 mar 2016.

CORLEC, Corpus Oral de Referencia de la Lengua Española Contemporánea. (s. f.). Madrid: Laboratorio de Lingüística Informática, Universidad Autónoma de Madrid. Consultado em <http://www.llf.uam.es/ESP/Info Corlec.html>. Acesso em: 16 set. 2016.

CREA, Corpus de referencia del español actual. Banco de datos da Real Academia Española de la lengua. Disponível em <http://www.rae.es $\geq$. Acesso em: 14 jul 2015. 
CRESTI, E.; MONEGLIA, M. (Org.). C-ORAL-ROM - Integrated Reference Corpora for Spoken Romance Languages. John Benjamins Publishing Company Amsterdam / Philadelphia, 2005.

LABLITA. Disponível em <http://lablita.dit.unifi.it/coralrom/index.html>. Acesso em: 07 ago 2016.

LINGUATECA. Disponível em <http://www.linguateca.pt/acesso/contabilizacao.php>. Acesso em Acesso em: 07 ago 2016.

PRESEEA, Corpus del Proyecto para el estudio sociolingüístico del español de España y de América. Alcalá de Henares: Universidad de Alcalá, (2014). Disponível em <http://preseea.linguas.net>. Acesso em: 13 jul 2015.

RASO, T.; MELLO, H. (Org.). C-ORAL - BRASIL I - Corpus de referência do português brasileiro falado informal. Minas Gerais: Editora UFMG, 2012. 